
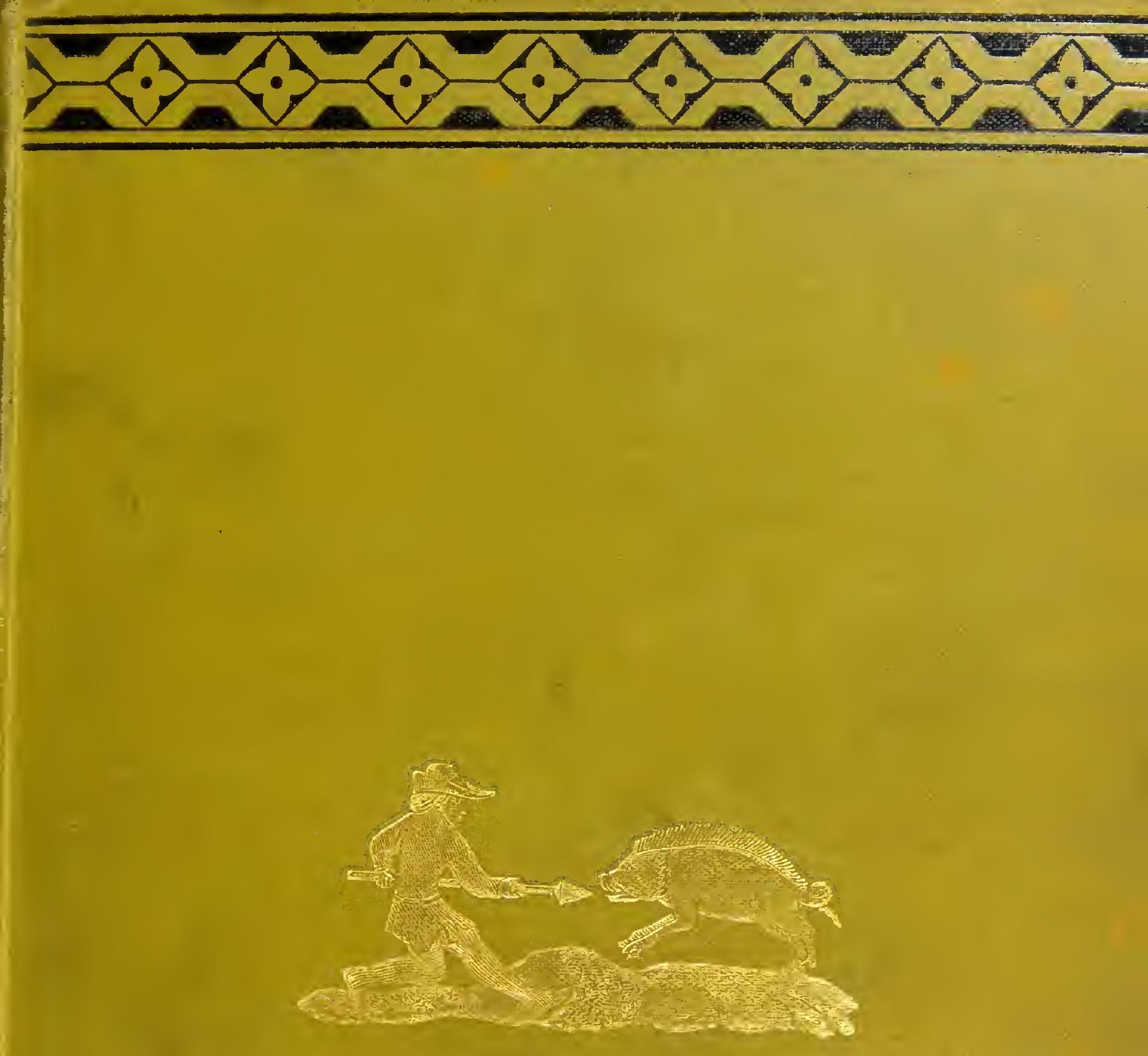

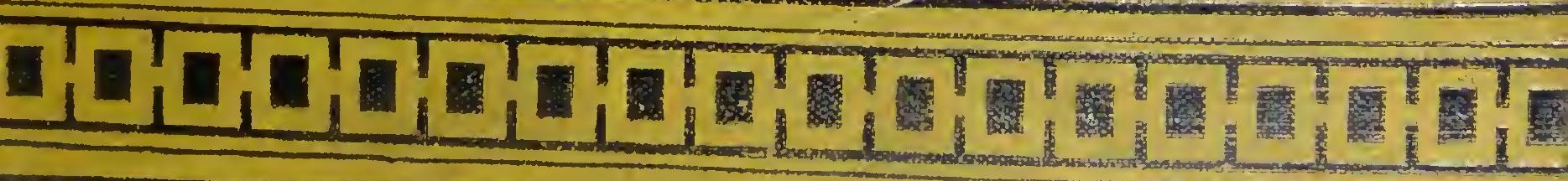

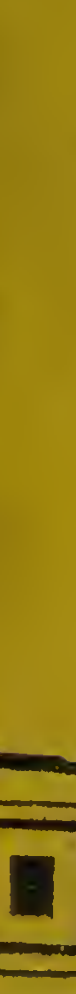



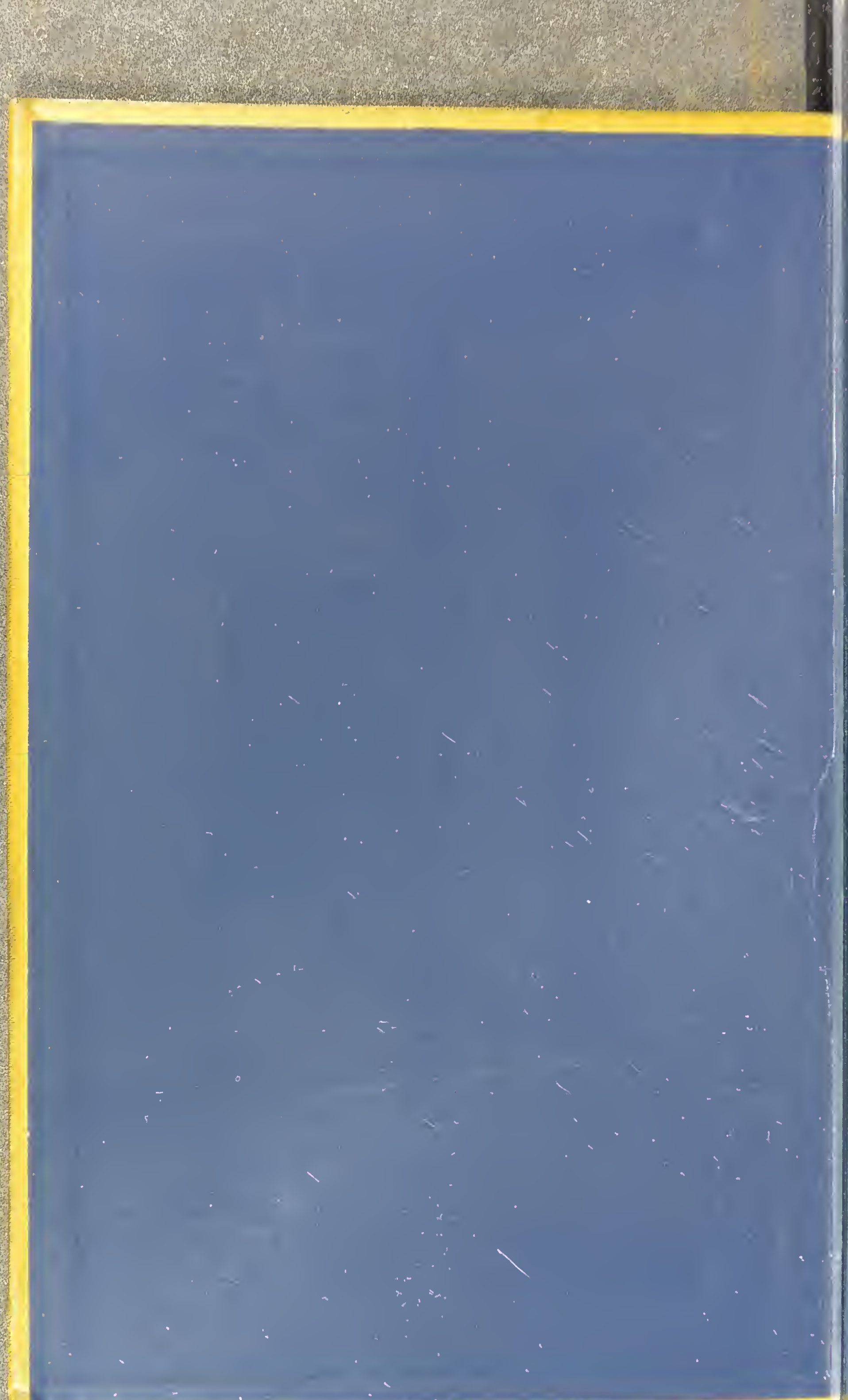



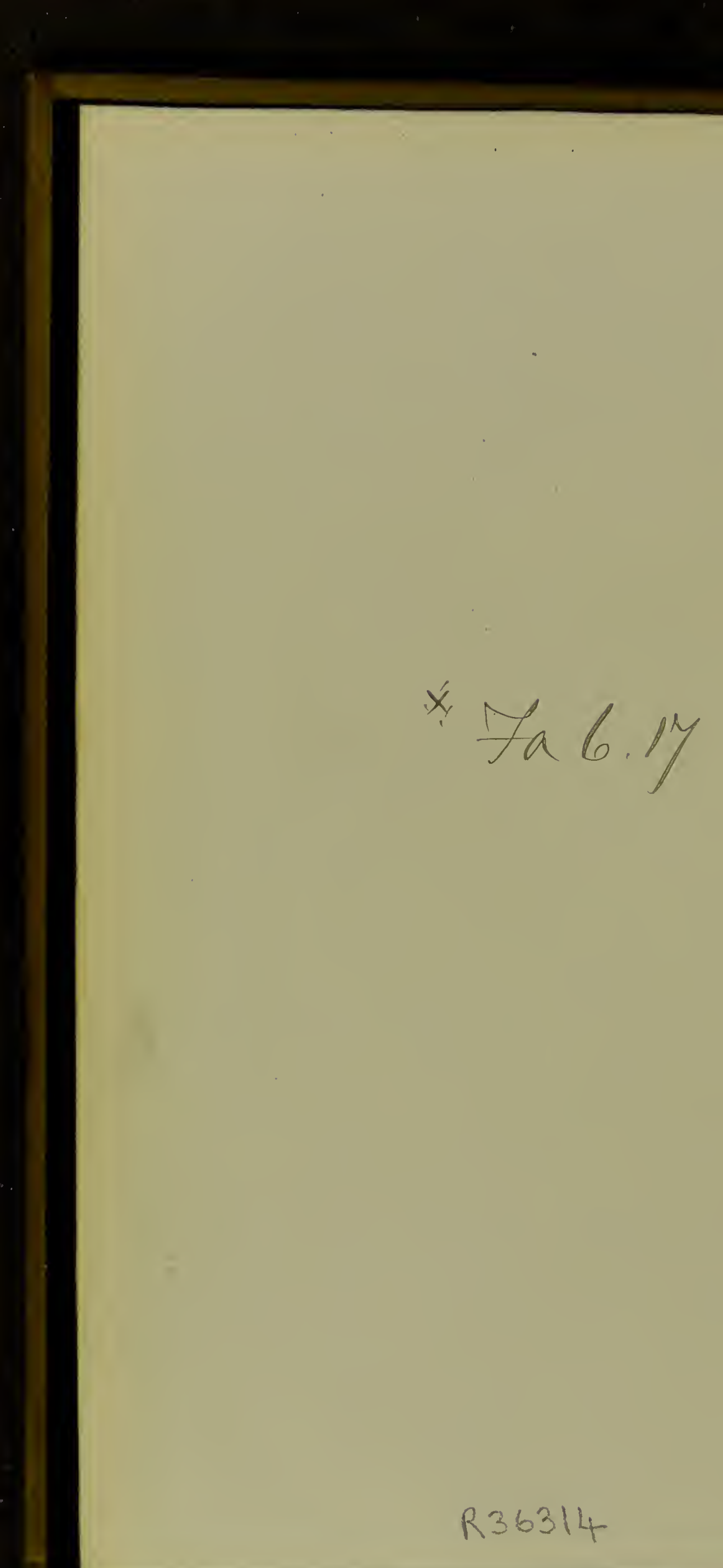

EXTINCT BRITIS 
EXTINCT BRITISH ANIMALS 
Eallantwne press

BALLANTYNE AND HANSON, EDINBURGH CIIANDOS STREET, LONDON 


\section{BRITISH ANIMALS}

\section{EXTINCT WITHIN HISTORIC TIMES}

WITH SOME ACCOUNT

OF

\section{BRITISH WILD WHITE CATTLE}

BI

\section{JAMES EDMUND HARTING, F.L.S., F.Z.S.}

AUTHOR OF "A HANDBOOK OF BRITISH BIRDS ;" "THE ORNITHOLOGY OF SHAKESPEARE," ETC. ETC.

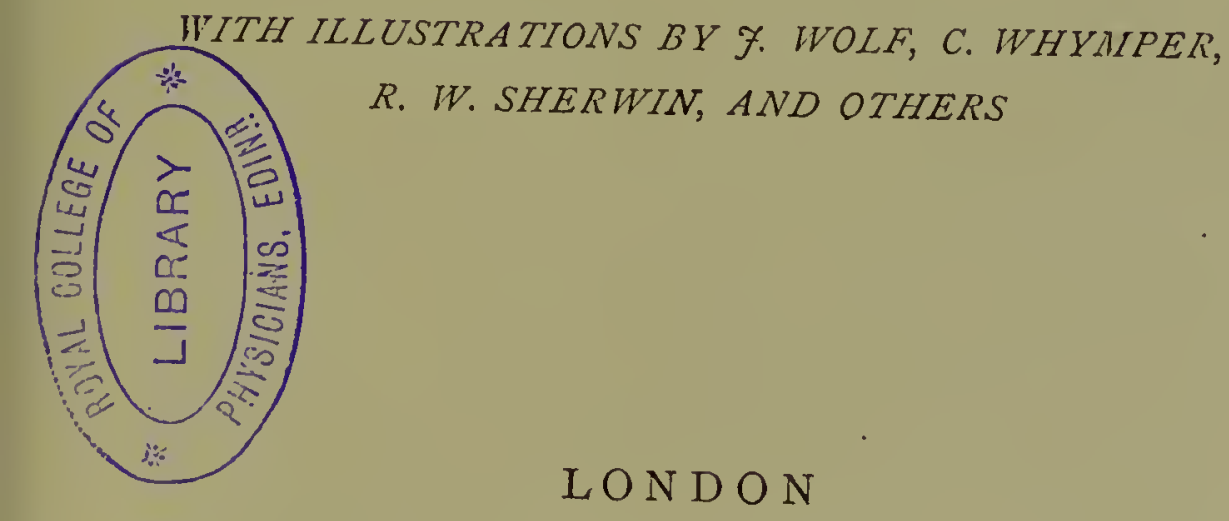

TRÜBNER AND CO., LUDGATE HILL I 880 
And in yon wither'd bracken's lair, Slumbered the wolf and shaggy bear;

Once on that lone and trackless sod

High chiefs and mail-clad warriors trod, And where the roe her bed has made, "Their last bright arms the vanquish'd laid.

The days of old have passed away Lilie leaves upon the torrent grey, And ail their dreams of joy and woe, As in yon eddy melts the swow; And soon as far and dim behind, We too shall vanish on the wind.

Lays of the Deer Forest. 


\section{PREFACE.}

Few who have studied the literature of British Zoology can have failed to remark the gap which exists between Owen's "British Fossil Mammals and Birds," and Bell's "British Quadrupeds ;" the former dealing chiefly with prehistoric remains, the latter with species which are still existing.

Between these two admirable works a connecting: link, as it were, seems wanting in the shape of a history of such animals as have become extinct in Britain within historic times, and to supply this is the aim of the present writer.

Of the materials collected, during many years of research, some portion has been already utilized in a Lecture delivered by the author before the "Hertfordshire Natural History Society," in October, I 879 , and in several articles in the Popular Science Review and the natural history columns of The Field.

The exigencies of time and space, however, neces-

* Popular Science Review, 1878,pp. 53, I4 I, 25 I, 396 ; and The Field, 1879 : Sept. 27 ; Oct. 4, 11 ; Nov. 1, 8, 29; Dec. 20 and 27. 
sitated a much briefer treatment of the subject in the journals referred to than is here attempted, and to these essays, now presented to the reader in a consolidated form, considerable additions have been made.

That the subject, admits of still further amplification the author is well aware; but "ars longa vita brevis est," and the materials at present collected have already assumed such dimensions, that it has been deemed preferable to offer them to the reader in their present form, rather than postpone publication indefinitely, in the hope of some day realizing an ideal state of perfection.

Should the present volume pave the way for future research on the part of others, the Author will be amongst the first to welcome the result of their labours. He has already to acknowledge his indebtedness to Dr. J. A. Smith and Messrs. Edward Alston, J. A. Harvie Brown, and J. P. Hoare, whose taste in the same line of research has prompted them to favour him with several interesting communications, which have been embodied in the following pages; while to Dr. Smith he is especially obliged for the use of four woodcuts which were prepared to illustrate papers of his own in the "Proceedings of the Society of Antiquaries of Scotland." 
In regard to that portion of the present work which treats of the ancient breed of wild white cattle, it may be thought, by some, a little preșumptuous on the part of the writer to deal with a subject on which an entire volume has been so recently and so ably written by the late $\mathrm{Mr}$. Storer. But it should be stated that almost all the materials for this portion of the book were not only collected long before Mr. Storer's work was published, but were on the eve of being incorporated in an important essay by Mr. Edward Alston, which was nearly ready for the press when Mr. Storer's volume appeared.

It would be ungenerous, however, on the part of the writer were he to withhold an acknowledgment of his indebtedness to Mr. Storer's work for many useful additions to his own (each, in fact, containing something which the other had not), and in particular for several details of the former extent of ancient forests, which have been embodied in the Introduction. 



\section{O N T ENTS.}

\section{PART I.}

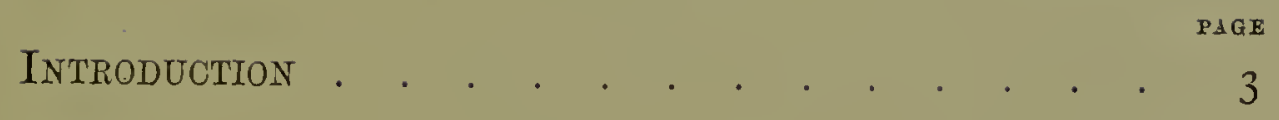

The Bear ... . . . . . . . . . . . . . I I

The Beaver . . . . . . . . . . . . . 33

The Reindeer . . . . . . . . . . . . . . . $6 \mathrm{I}$

The Wild Boar . . . . . . . . . . . . 79

THe Wolle . . . . . . . . . . . . . II 5

Concluston . . . . . . . . . . . . . 206

PART II.

Wild White Cattle 


\section{LIST OF ILLUSTRATIONS.}

The BeAr PAG B

Fossil Cranium of Bear, Dunfriesshire. . . . . I 3

Recent Cranium of Bear. Under Surface . . . I5

Bear Hunt. From an old print . . . . . . . I8

Anglo-Saxon Gleemen's Bear Dance . . . . . 20

Bear-baiting. From a carved seat of the I4th century 25

The Benver . . . . . . . • • . • . . . 33

Cranium from the English Fens. Upper Surface . 44

The same. Under Surface . . . . . . . 45

Lower Jaw of Beaver from the English Fens . . 5 I

A Beaver at work . . . . . . . . . . 60

The ReINdeER . . . . . . . . . . . . . 6I

Fragments of Reindeer's Horn, from Caithness . . 7I

Antler of Reindeer, from Orkney . . . . . . 75

THE WILd BoAR . . . . . . . . . . . . 77

Wild Boar Hunting. From a MS. of the gth century 79

Spearing a Boar. From a MS. of the I4th century 85

Skull of Wild Boar . . . . . . . . . . . 86

Tracking a Wild Boar. Sixteenth century . . . IO3

Group of Wild Boars, from a carved horn . . . . Io9

The Boar's Head, Eastcheap . . . . . . . . II I

THE WOLF • • • • • • • • • • • • • • . II5

Skull of Wolf . . . . . . . . . . . . . . I I

Cranium of Wolf. Upper Surface . . . . . I2O

Cranium of Wolf. Under Surface . . . . . . I2I

Teeth of Wolf. Natural Size. . . . . . . I23

Wolf hunt. Sixteenth century . . . . . . . I5 I

Irish Wolf-hound . . . . . . . . . . . I88

Ancient Hunting Horn . . . . . . . . . . 205

The Relay . . . . . . . . . . . . . . 209

Wild White Cattle . . . . . . . . . . . 2I3

Skull of Wild Ox, Fifeshire . . . . . . . 216

Skull of Wild Ox, Lancashire . . . . . . . . 2I7

Coin of Cunobelin, with Wild Ox on reverse . . . 219

Wild Bull of Chartley . . . . . . . . . . 23 I

Wild Bull of Chillingham . . . . . . . . . . 233 
PART I.

EXTINCT BRITISH ANIMALS. 



\section{EXTINCT BRITISH ANIMALS.}

\section{INTRODUCTION.}

The interest which attaches to the history of extinct British animals can only be equalled by the regret which must be felt, by all true naturalists, at their disappearance beyond recall from our fauna.

It is a curious reflection at the present day, as we pass over some of the wilder parts of the country, that at one time these same moors and woods and glens, which we now traverse so securely, were infested to such an extent with ferocious animals, that a journey of any length was, on this account, attended with considerable danger. Packs of wolves, which usually issued forth at night to ravage the herdsman's flocks, were ever ready to attack the solitary herdsman, or unwary traveller on foot, who might venture to pass within reach of their hiding-places. In the oak woods and amongst the reed-beds which fringed the meres, wild-boars lurked while munching their store of acorns, or wallowing, as is their wont, in lacustrine mire, while they searched for the palatable roots of aquatic 
plants. Many a traveller then had cause to rue the sudden and unexpected rush of some grand old patriarch of the "sownder," who, with gnashing tusks, charged out upon the invader of his domain, occasionally unhorsing him, and not unfrequently inflicting severe injuries upon his steed. In the wilder recesses of the forest, and anongst the caves and boulders of the mountain side, the bear, too, had his stronghold, and though exterminated at a much earlier period, long co-existed with the animals we have named; while in a few favoured localities in the west and north, the harmless, inoffensive beaver built its dam, and dived in timid haste at the approach of an intruder.

At the present day it is difficult to realize such a state of things, unless we consider at the sarne time the aspect and condition of the country in which these animals lived, and the remarkable physical changes which have since taken place. Nothing we have now left can give us any idea of the state of things then; not the moors of North Derbyshire, West Yorkshire, and Lancashire, the wild wastes of Westmoreland, Cumberland, and Northumberland, nor even the extensive deer-forests and moors of the Scottish Highlands; for the pathless woods which then covered a great part of these districts are all gone, and so also are the thick forests which, outside of but connected with them, skirted these higher grounds. The advance of man and the progress of cultivation has destroyed most of these wild woods, but it was not so in late Saxon and in 
early Norman times. Even in the less hilly districts more than half the country was one vast forest, and in the north at least these forests flanked the mountain ranges, extending their wild influence, and at the same time rendering them more inaccessible and wilder still.

Between the tenth and twelfth centuries, great forests came up almost to the gates of London. In a curious tract entitled "Descriptio nobilissimce civitatis Londonice," written by Fitz-Stephen, a monk of Canterbury, in II74, it is stated that there were open meadows of pasture lands on the north of the City, and that beyond these was a great forest, in whose woody coverts lurked the stag, the hind, the wild-boar, and the bull.

Two-thirds, or nearly, of the county of Stafford was, even in relatively modern times, either moorland or woodland. The northern part, going nearly up to Buxton, was moorland; the central and eastern part forest. Harwood, in his edition of Erdeswick's "Survey of Staffordshire," quoting Sir Simon Degge, says: "The moorlands are the more northerly mountainous part of the country lying betwixt Dove and Trent; the woodlands are the more southerly level part of the country. Between the aforesaid rivers, including Needwood Forest, with all its parks, are also the parks of Wichnor, Chartley, Horecross, Bagots, Loxley, and Paynesley, which anciently were all but as one wood, that gave it the name of woodlands." Leland, about I536, though he speaks of the woods being then much reduced, con- 
firms this, and even carries this country of woods farther south. He says: "Of ancient tyme all the quarters of the country about Lichefeild were forrest and wild ground."* 'That would bring the Staffordshire woodlands close up to the purlieus of Charnwood Forest, in Leicestershire. Nor is this all; for about three miles north-west of Lichfield com. mences Cannock Chase, with its parks as numerous and extensive as those of Needwood, firom which it was separated only by the River Trent. This chase, even at a comparatively recent period, was "said to contain 36,000 acres," while "in Queen Elizabeth's time Needwood Forest was twenty-four miles in circumference." $\dagger$

The mountainous and moorland district to the north of Staffordshire, as many names of places still indicate, was also heavily wooded at one time, and contains, near its northern extremity, the singular defile of rocks and caverns locally called Ludchurch, said to have been the scene of Friar Tuck's ministrations to Robin Hood and his merry men. $\neq$ This part of Staffordshire, bounded by the river Dove on its eastern side, and on the west passing close to Congleton in Cheshire, and another ancient forest known as Maxwell forest, runs like a wedge near Buxton into that wild country where the great

* Leland, "Itincrary," ed. Hearne, vol. iv. p. II4.

+ Erdeswiek, "Survey of Staffordshire," ed. Harwood, pp. I92, 279. These were both celcbrated for their oals and hollies: those in Needwood alone, in 1658, when it had been mueh redueed in extent and denuded of its timber, being valued at 30,7 rol.

‡ Storer, "Wild Cattle of Great Britain," p. 65. 
forest of Macclesfield, the Peak forest, and the high Derbyshire moors uniting together constitute " that mountainous and large featured district which in ancient times had been well timbered and formed part of the great midland forest of England.* And a part only; for we have seen that this midland forest district, of which the Peak was the centre, included towards the south the greater part of Staffordshire, while towards the east an imaginary line only separated it from the mighty forest of Sherwood. From Nottingham to Manchester was one continuous forest, and far into Yorkshire the great moor extended to join other and more northern forests there. From the Peak northwards, throughout West Yorkshire and East Lancashire, the forests, moors, and mosses connected with this mountain range were immense.t Some idea of their extent may be gathered from the remarks of the learned Dr. Whitaker, who, describing Whalley, in Lancashire, in late Saxon and early Norman times, says:- "If, excluding the forest of Bowland, we take the parish of Whalley at a square of $16 \mathrm{I}$ miles, from this sum at least 70 miles, or 27,657 acres, must be deducted for the four forests, or chaces, of Blackburnshire, which belonged to no township or manor, but were at that time mere derelicts, and therefore claimed, as heretofore unappropriated, by the first Norman lords. There will therefore remain for the different manors and townships 36,000 acres or thereabouts, of which 3,520 , or not quite a tenth part, was in a state of

"Robertson, "Buxton and the Peak,"p. 4I. † Storer, p. 66. 
cultivation; while the vast residuum stretched far and wide, like an ocean of waste interspersed with a ferv inhabited islands." ${ }^{*}$ Let us try to realize the state of things, when out of 63,657 acres of land, over 60,000 were either forests or waste, and nearly half of that amount unclaimed and unappropriated, while close at hand towards the north was the still larger and wilder forest of Bowland, so admirably described by Whitaker, and towards the south that of Rosendale with an amazing range of moors beyond it. But this statement only shows how the great central range was covered and fringed with wastes and forests on its western side. On the eastern side in the same neighbourhood, the country of Craven, it was just the same even so lately as the time of Henry VIII. Leland says:- "The forest, from a mile beneth Gnaresborough to very nigh Bolton yn Craven is about twenty miles in length; and in bredeth it is in sum places an viii miles ;" the whole intermediate district between Bolton and Bowland forest, or between it and Vhalley, being about as wild as anything can be. In the north of England the same state of things prevailed, often on an even larger scale; one forest alone in Cumberland, and that not in its wildest part, being described in "The Chartulary of Lanercost Priory" as extending at the time of the Norman Conquest from Carlisle to Penrith, a distance of eighteen miles, and as "a goodly forest, full of woods, red-deer and fallow, wild swine, and all manner of wild beasts."

* Whitaker, "History of Whalley," p. $17 \mathrm{r}$. 
As for Scotland, we can scarcely over-estimate the wildness that everywhere prevailed, when in the south a vast forest filled the intervening space between Chillingham and Hamilton, a distance, as the crow flies, of about eighty miles, including within it Ettrick and numerous other forests ;* and further north the great Caledonian wood, known even at Rome, covered the greater part of both the Lowlands and Highlands, its recesses affording shelter at one time to bears, wolves, wild-boars, and wild white cattle.

Enough, perhaps, has been here advanced to show that the whole of this immense range of mountains and liills, with its vast forests and wastes, was as favourable a tract of country for the preservation of aboriginal wild animals as could well be conceived; but for further details of the situation and former extent of English forests the reader may be referred to Whitaker's "History of Manchester" (Bk. I. p. 337); Gilpin's "Forest Scenery" (vol. ii.), to which Sir Thomas Dick Lauder, in his edition (1834) has made some valuable additions; Scrope's "Art of Deer Stalking" (3rd ed. 1847); and Mr. Evelyn Shirley's "English Deer Parks" (1867).

To describe the various modes of hunting in these early times would be beside the purpose of the present work, which is, rather, to collect together evidence, geological and historical, of the former existence here of certain wild animals which have become extinct within historic times. On the subject of hunting,

* Storer, p. 68. 
then, we must be brief, and will here be content with quoting the following remarks of Mr. Earle in his edition of the Saxon Chronicle. "Now-a-days," he says, "men hunt for exercise and sport, but then they hunted for food, or for the luxury of fresh meat. Now the flight of the beast is the condition of a good luunt, but in those days it entailed disappointment. They had neither the means of giving chase or of killing them at a distance, so they used stratagem to. bring the game within the reach of their missiles. A labyrinth of alleys was penned out at a convenient part of the wood, and here the archers lay under covert. The hunt began by sending men round to break and beat the wood, and drive the game with dogs and horns into the ambuscade. The pen is the haia so frequently occurring amongst the silvce of Domesday. Horns were used, not, as with us, to call the dogs, or, as in France, to signal the stray sportsman; but to scare the game. In fact it was the battue, which is now, under altered circumstances, discountenanced by the authorities of the chase, but which, in early times, was the only way for man to. cope with the beasts of the field." Such, at least, was the course usually adopted. Particular animals, however, were hunted in a particular manner, and to some of these modes we shall have occasion to, refer later. 


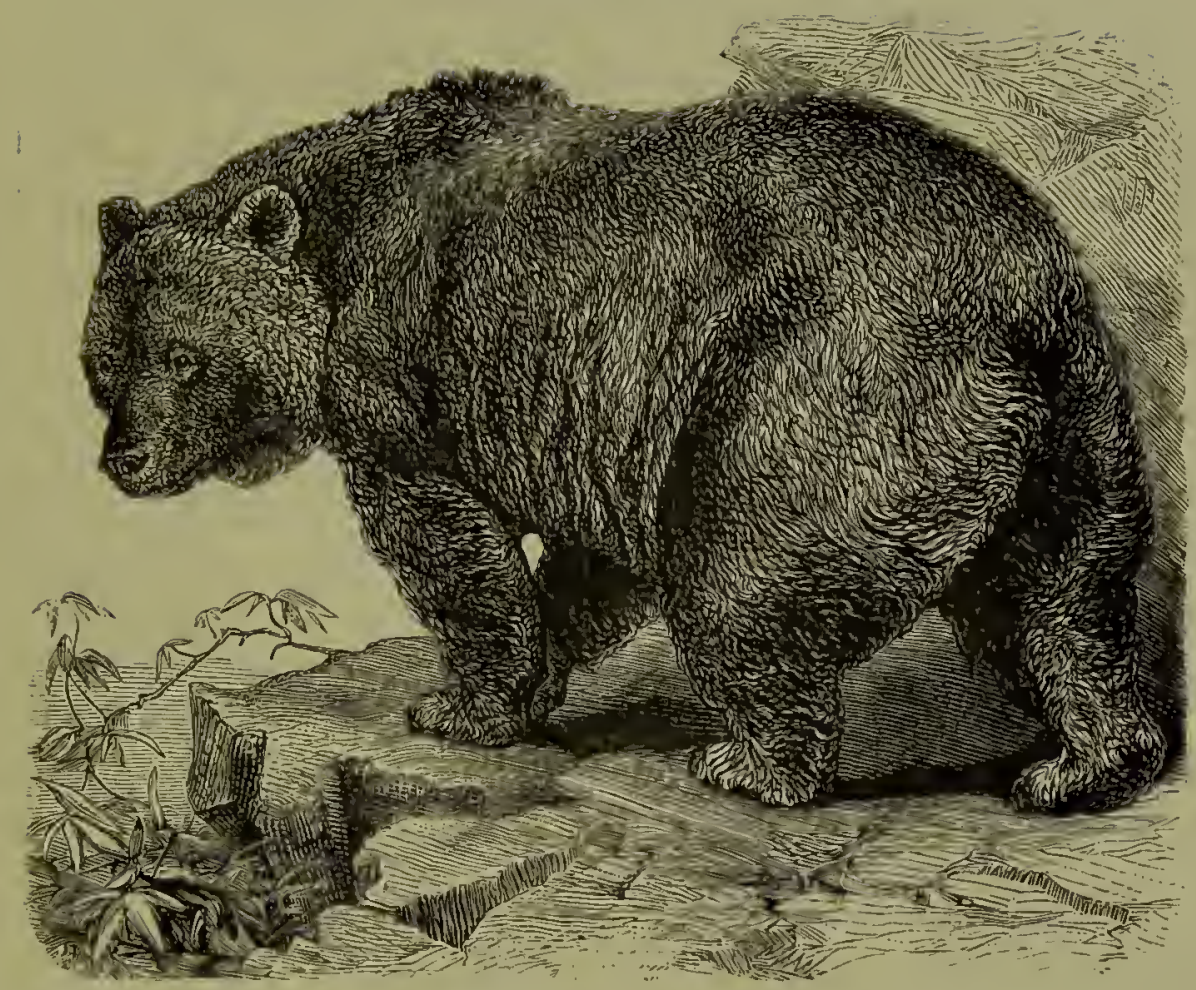

THE BEAR.

Ursus arctos.

To treat first of the earliest historic species which has died out, no doubt can exist that the Brown Bear inhabited Britain in times of which history takes cognisance, the few written records which have come down to us of its former existence here being supplemented by the best of all evidence, the discovery of its remains. These have been found in the most recent formations throughout England, which can scarcely be regarded as fossil, and, if not abso- 
lutely identical with those of the Bear which still exists in many parts of the European continent at all events indicate only a variety.*

In Britain, says Professor Boyd Dawkins, the Bear survived those changes which exterminated the characteristic post-glacial mammalia, and is found in the prehistoric deposits both in Great Britain and Ireland, and is of considerable interest, because it is the largest of the post-glacial carnivores which can be brought into relation with our history. A nearly perfect skull from the marl below the peat in Manea Fen, Cambridgeshire, and now in the Woodwardian Museum, Cambridge, has been described and figured by Professor Owen, who has also described portions of another skull from the same locality. In I 868 Dr. Hicks found remains of the Brown Bear in peat at St. Bride's Bay; and numerous bones and teeth of this animal have been discovered at various times in Kent's Cavern, Devonshire.

The exploration of the Victoria Cave, near Settle, revealed the fact that the Brown Bear afforded food to the Neolithic dwellers in the cave, who have left the relics of their feasts and a few rude implements at the lowest horizon; the broken bones and jaws of this animal lying mixed up with the remains of the Red-deer, Horse, and Celtic Shorthorn.t

Nor are we without direct testimony that the Bear was killed by the hand of man during the Roman occupation of Britain. In the collection of

* Owen, "British Fossil Mammals," p. 78 .

+ Boyd Dawkins, Pop. Sci. Review, 186r, p. 247. 
bones from the "refuse heaps" round Colchester made by Dr. Bree, the remains of this animal were found along with those of the Badger, Wolf, Celtic Shorthorn, and Goat. Professor Boyd Dawkins has also met with it in a similar "refuse heap" at Richmond, in Yorkshire, which is most probably of Roman origin.

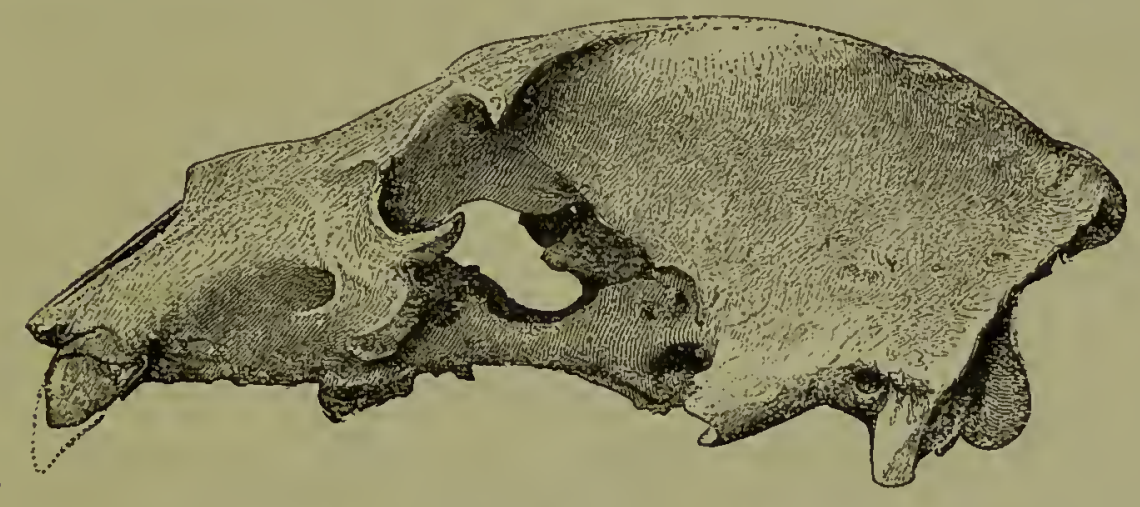

CRANIUM OF BROWN BEAR, DUMFRTESSHIRE.

Dr. J. A. Smith has described and figured* the skull of a large Bear which was found with a rib of the same animal in a semi-fossil condition at Shaws, in Dumfriesshire, in peat moss lying on marl, among the most recent of all our formations, associated moreover with the Red-deer, Roe-buck, Urus, and Reindeer; the skull being that of a large adult animal of great size and strength. $\dagger$ Strange to say, these are the only remains of the Bear which have yet been discovered in Scutland.

As regards Ireland, some doubt seems to exist in the minds of palæontologists whether any of the ursine remains discovered there are referable to * "Proc. Soc. Antiq. Scotland," vol. xiii. p. 360 (1879).

+ For permission to copy the figure of this skull the author is indebted to Dr. J. A. Smith and the Society above referred to. 
Ursus arctos.* Dr. Leith Adams, writing on 'Recent and Extinct Irish Mammals' ("Proc. Roy. Dublin Soc.," r 878), has very fully described several skulls and other portions of ursine skeletons exhumed in Leitrim, Longford, Westmeath, King's County, Kildare, Waterford, and Limerick, and after comparing them with similar bones of Ursus spelcus, $U$. fossilis, $U$. ferox, $U$. arctos, and $U$. maritimus, has arrived at the following conclusion:-

"A study of the osteological characters of these ursine remains which represent all the authenticated instances of discoveries hitherto recorded from Ireland, appears to me to furnish characters referable only to one species, which, on the score of dimensions and general features, is inseparable from the so-called Ursus fossilis of Goldfuss, $\dagger$ and at all events from the smaller Spelean Bear found in English and other deposits, as distinguished from the larger congener found also in England, but more plentifully on the continent of Europe. Unless the skull from Kildare represents the Ursus arctos (and that, I think, is doubtful), $f$ all the other's seem to me to belong to

* See Dr. R. Ball on the Skulls of Bears found in Treland, "Proe. Roy. Irish Acad." vol. iv. p. 416 (I850); Wilde, "Proc. Roy. Irish Acad.," vol. vii. p. I92 (1862); Scott, "Catalogue of Mammalian Fossils discovered in Ireland," "Jour. Geol. Soc. Dublin," vol. x. p. I44 (1864); Dr. Carte, "Jour. Geol. Soc. Dublin," vol. x. p. II 4 (1864).

+ The relationship between Ursus ferox and Ursus arctos is very close, not only as regards fossil but also recent individuals, so much so that by external appearance only they are indistinguishable.

+ A fine cranium $13^{\frac{1}{4}}$ inches in length was found in cutting a new ehamnel for the river Boyne, in the barony of Carberry, co. Kildare; and is of peculiar interest from its resemblance to the Pyrenean variety of $U_{r} \cdot s_{s} a^{\circ} \mathrm{clos}$, to which it lias been referred by Dr. Carte. 
the Ursus fossilis, which, so far as osteological and dental characters are concerned, would appear to have been the progenitor of the recent Ur'sus ferox, now repelled to Western North America. In this latter view I am supported by the distinguished palæontologist, Mr. Busk, F.R.S., whose differentiations, as regards several of the Irish crania, were

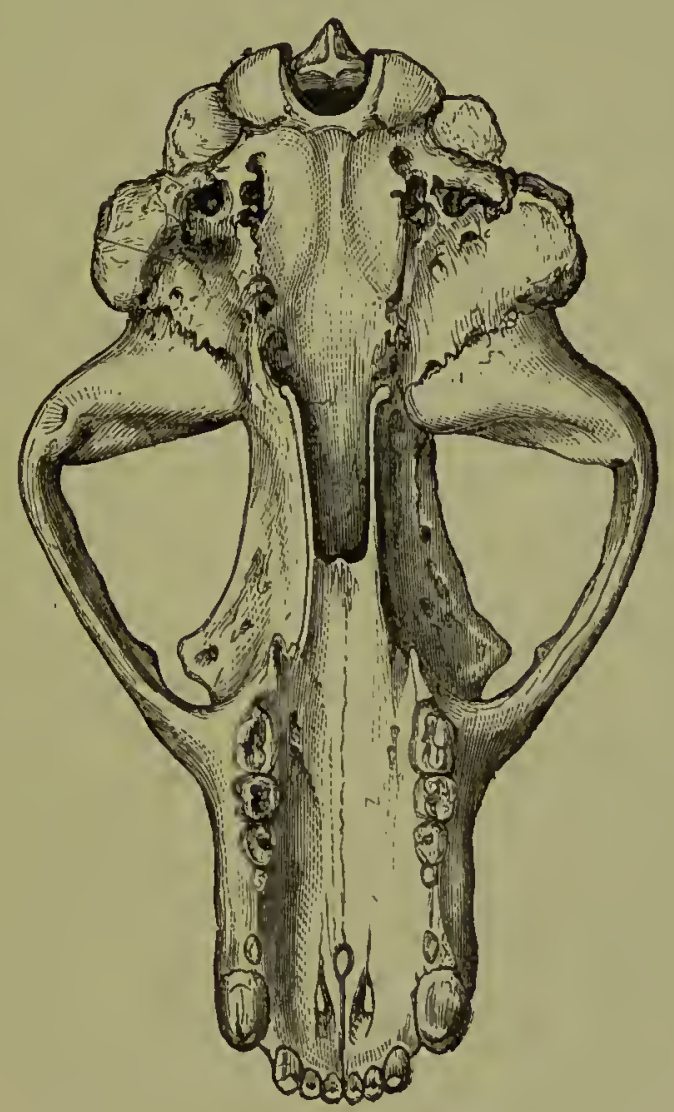

RECENT CRINIUMI OF BEAR. UNDER SURFACE. ( $\frac{1}{t}$ NAT. SIZE.)

made before I commenced to study them. It may be said, therefore, that Ursus ferow, as in England, belonged to the prehistoric fauna, and was a native of the island in the days of the Reindeer, Mammoth, Horse, and Wolf, with which its remains have been found associated, as also with exuvia of the Red- 
deer, Fox, and Variable or Alpine Hare; and although not found along with the Irish Elk, it has been generally met with in similar lacustrine beds. It seems to me that, as in the neighbouring island, if the Brown Bear had ever been a native of Ireland, it would, as in Scotland and England, have come down to the historical period; so that the fact of no notice of its presence, and the very emphatic assertions or silence of Bede, St. Donatus, "* Giraldus Cambrensis, and Pennant, seem to me to bear out the results of recent disclosures. The probability is, therefore, that, like its congeners, all, excepting the Hare and Red-deer, became extinct in the island before man commenced to make records of the ferce of the country; for it is a remarkable circumstance that in all the remains of Irish extinct mammals, none present the fragmentary characters afforded by the cavern deposits of the sister island; thus showing on the one hand, that they had not been destroyed by man, nor by the bone-crunching hyæna, but that they met their deaths, for the most part, through natural causes and accidents."

The Welsh Triads, some of which are supposed to have been compiled in the ninth century, but most of which are of a much later clate, $\uparrow$ say that "the Kymry, a Celtic tribe, first inhabited Britain ; before them were no men there, but only bears, wolves, beavers, and oxen with high prominences."

* In Ireland, according to St. Donatus, who died in 840 , the Bear was not indigenous: "ursor"um rabies nulla est ibi."

+ See Stephens, "Literature of the Kymry," p. 427 (ed. 1876), and Appendix. 
Many places in Wales, says Pennant, still retain the name of Penarth, or "the bear's head," another evidence of their former existence in our country.*

Our illustrious countryman, John Ray, in his "Synopsis Methodica Animalium" (a small octavo volume, published in I693), tells us (pp. 213, 214) that his friend Mr. Edward Llwyd, in an old Welsh MS. on British laws and customs, discovered certain statutes and regulations relating to hunting, from which it appeared that the Bear was formerly reckoned amongst the beasts of chase ( $E$ novem qua venantur ferarum generibus tria tantum latrabilia $\dagger^{-}$ esse, ursum, scandentia, $\downarrow$ et phasianum, and its flesh was esteemed equally with that of the Hare and the Wild Boar: "Summam seu prcecipuce cestimationis ferinam esse, ursi, leporis et apri."§

* "British Zoology," vol. i. p. gr (ed. r8r2).

† Latrabilia, "baitable animals." The term is thus explained by Ray (op. eit.) : "Ursus fera latrabilis [baitab]e] dieit!r, quia cum tardigradus sit, nec velociter currerc possit, eanes eum faeile assequuntur, contra quos deinde corpore in elunes erecto aliquandiu se defendit; canes autem initio timidi nee propius accedere aut eum cllatrant antequam aggrediantur et occidant." Sec also Stuart, "Lays of the Deer Furest," vol. ii. p. 441.

+ Seandentia, sc., "elimbers," the marten and wild cat, perhaps also the squirrcl. The mention of the pheasant here is remarkable, and we should be curious to discover the date of this MS., if still preserved, and the Welsh equivalent, in Llwyd's opinion, for "phasianum." We know from another source (a M.S. dated about II77) that this bird was to be found here in 1059, since it is included in a bill of fare of that date prescribed by Harold for the household of the canons at Waltham Abbcy. It would be interesting to know whether the Welsh MIS. referred to was an earlier document or otherwise.

\$ In "a letter (dated Sept. I4, I696) from the late Mr. Edward Llwyd, Keeper of the Ashmolean Museum in Oxford, to Dr. Tanered Robinson, F.R.S., containing several observations in Natural History, 
Of the ancient British methods of hunting the Bear, we are but imperfectly informed. We learn, however, from rude descriptions and ruder figurings, that he was watched to his couch, or was traced to his winter retirement, when arrows, pikes, clubs, javelins, and long knives, were used against him; he was also occasionally betrayed into a pitfall. In

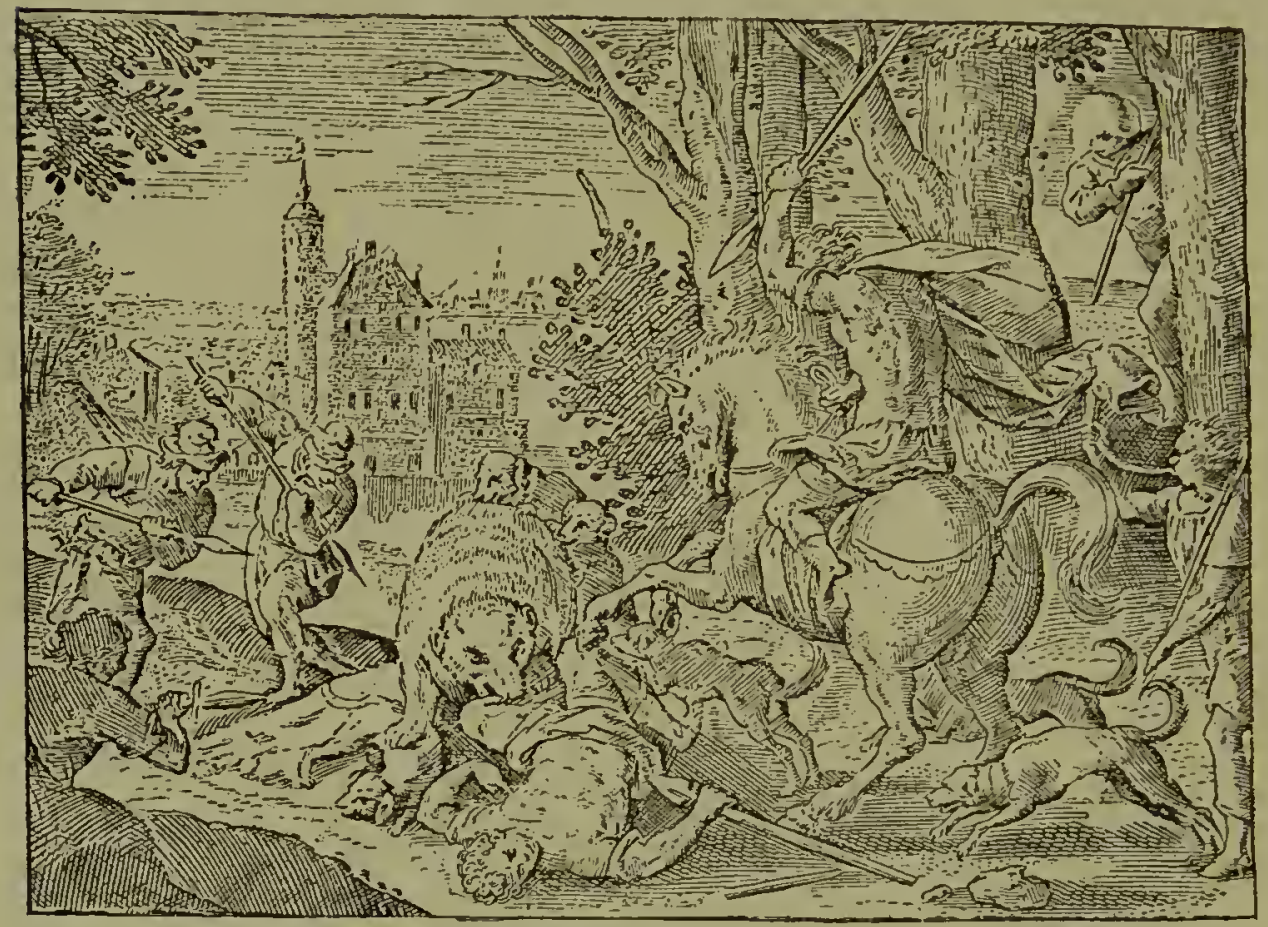

BEAR HUNT. FRON AN OLD PRINT IN POSSESSION OF THE AUTHOR.

later times the Bear was trailed with boar-hounds, and despatched by the spear or knife of the hunter, made in his travels through Wales" ("Phil. Trans.," rol. xxrii. p. 462), the writer observes:-

"Sir William Williams hath several Welsh MSS. (tho' I think no dietionary) that would be of use to me; but his sou tells me he's resolv'd never to lend any. They are ehiefly moderu copies ont of Hengwrt Study in Meirionydlsthire, which I am promis'd free aecess to ; and have this time taken a Catalogue of all the ancient MSS. it contains. There are the works of Talicfyn, Ancuryn gwawdydh, MIyrdhyn ab Morvryn and Kygodio Elaeth, who lived in the fifth and 
as the animal rose to grapple with the dogs, or with their master. Bear hunting must have been always a dangerous sport, in this respect and if ever the great Cave Bear was an object of the hunters' attack, the boar-hunt of Calydon, as described by Ovid, could alone have furnished a parallel.

That bears were to be found in Britain during the eighth century may be inferred from the fact that in the "Penitentiale" of Archbishop Egbert, drawn up about A.D. 750, it is laid down (lib. iv.) that " if any one shall hit a deer or other animal with an arrow, and it escapes and is found dead three days afterwards, and if a dog, a wolf, a fox, or a bear, or any other wild beast hath begun to feed upon it, no Christian shall touch it."*

In the time of Edward the Confessor, as we learn from "Domesday," the town of Norwich furnished annually one Bear to the king, and six dogs for the baiting of it. $\dagger$

Baiting wild animals was a favourite pastime with sixth centuries (but the small MS. containing them all seems to have been copied about 500 year's ago), as also of scveral others valuable in their kind." In a subsequent letter to Dr. Robinson, dated Lhan Dyvodog, Glamorganshire, Sept. 22, I697, he says:-“I had no sooner received your last but was forced to retire in a liurry to the mountaincus parts of this county, in order to copy out a large Welsh MS. which the owner was not willing to spare above two or three days, and that in his neighbourhood. It was written on vellum about 300 years since, and contained a collection of most of the ancient writers mentioned by Dr. Davies at the end of the Welish dictionary. So I thought it better trespassing on the gentleman's paticnce that lent it, than lose such an opportunity as perhaps will not occur again in my travels. 'This is the occasion of my long silence-the transcribing of that book taking up two months of our time."

* Migne, "Patrolngia Cursus Completus," tom. lxxxix. p. 426.

† Galc, rol. i. p. 777 ; Blount, "Ancient Tcnures," p. 3i 5 (ed. I8 I 5). 
the Romans and their imitators, the Roman Britons. And as amphitheatres were constructed of squared stone, and in a magnificent style for these exhibitions at Rome, so were others erected here in Britain in a less pretentious style of architecture, and of the humbler materials of clay, chalk, gravel, and turf. Such are the great amphitheatres at Silchester and Dorchester, once extending in several rows of seats,

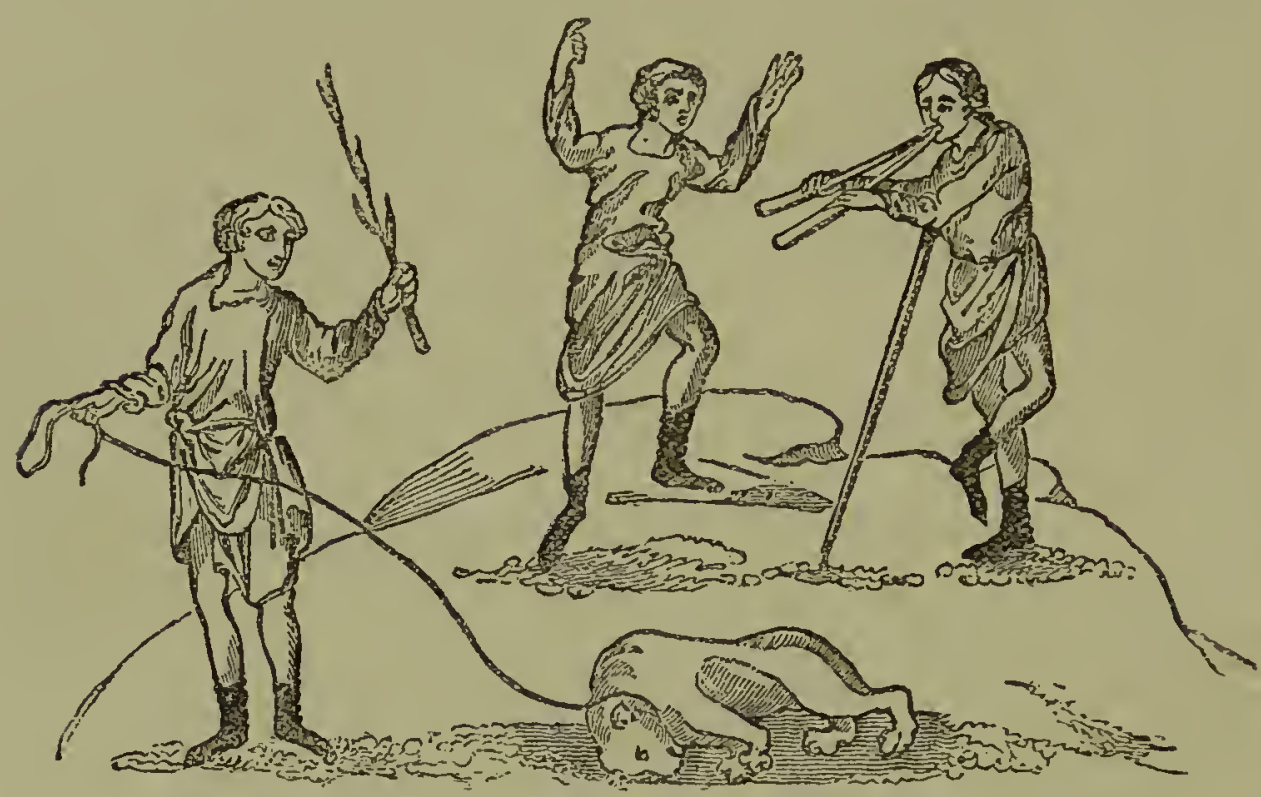

ANGLO-SAXON GLEEMEN'S BEAR DANCE. TENTH CENTURY.

and still including an arena of nearly two hundred yards in circumference.*

In all probability the trained bears exhibited by the Anglo-Saxon Gleemen were native animals taken young and tamed.

So far as history informs us, it would seem that Scotland, and more particularly the great Caledonian forest, was the chief stronghold of our British Bears. Bishop Leslie says that that great wood was * "Itin. Cur.," pp. 155-170; "Phil. Trans." 1748, p. 603. 
once "refertissimam," full of them." Camden, too, writing of Perthshire, observes: "This Athole is a country fruitful enough, having woody vallies, where once the Caledonian forest (dreadful for its dark intricate windings and for its dens of Bears, and its huge wild thick-maned bulls) extended itself far and near in these parts." $\dagger$

After the occupation of Britain by the Romans, Caledonian Bears seem to have been perfectly well known in Rome. We learn from Martial that they were used for the purpose of tormenting malefactors, of which we have an instance in the fate of Laureolus : +

Nuda Caledonio sic pectora præbuit urso,

Non falsa pendens in cruce, Laureolus.

Which may be Englished :

Thus Laureolus, on no ideal cross suspended,

Presents his nude body to the Caledonian bear.

Camden, quoting Plutarch, assures us " that they transported Bears from Britain to Rome, where they held them in great admiration." " How these Bears were captured, and in what way they were transported to the coast and shipped on board the Roman

* "De oricrine, moribus, \&c., Scotorum," I 578.

† "Britannia," ed. Gibson, vol. ii. p. 293; ed. Phil. Holland, ii. p. 40. Sce also "Old Statist. Acc. Scotl.," vol. xii. p. 449 (I794).

+ Martial, “De Spect.," vii. 3, 4.

$\S$ Camden, cd. Holland, ii. p. 3I. Gough, in his cdition (vol. iii. p. 367), says that neither he nor Pennant could discover the passage referred to, nor have we been more successful. The passage from Martial, however, is thus commented on in the Delphin edition:"Culedonia, renio Britannice, ubi sylve densissince unde scevi u"si Romam mitlebantur." 
galleys, must, we fear, for ever remain matters for speculation. We do not even know the precise period at which these very hazardous consignments were made; but it may be assumed to have been probably about the same time that Wolf-dogs were being exported to Rome, which we know was about the latter end of the fourth century. A Roman consul of that day, Symmachus by name, writing to his brother Flavinus over here, thanks him for a present he made him of some dogs which he calls Canes Scotici, and which were shown at the Circensian games, to the great astonishment of the people, who could not believe it possible to bring them to Rome otherwise than in iron cages. It was no doubt in iron cages that the Bears were transported.

Some commentators have supposed that the dogs here referred to were English mastiffs; but it may be remarked that for some time before Symmachus lived, and for many centuries after, Ireland was well known by the name of Scotia, and the appellation "Canes Scotici," while inapplicable to English mastiffs, would be appropriate to Irish wolf-hounds. Moreover, the dogs upon which the highest value was always set in former times were those which were of use for the chase of wild animals, and we know from various sources that Wolf-dogs were held in such esteem as to be considered worthy the acceptance of monarchs, and were frequently sent abroad as presents to foreign potentates.*

* See an article by the writer, on the Irish Wolf-dog, in Baity's Magazine for September, I879. 
As regards the former existence of Bears in the Highlands, a shadow of their memory, says Stuart* is preserved in their Gaelic name, Magh-Ghamleainn; $\dagger$ and the traditions of some remote districts which retain obscure allusions to a rough, dark, grisly monster, the terror of the winter's tale, and the origin of some obsolete names, in the depths of the forest and the dens of the hill. $\ddagger$ Hence Ruigh-nabeiste, the monster's slope, Loch-na-beiste, the monster's lake; for beist in Gaelic signifies generally, not, as might be inferred from its similarity to the English word, a mere animal (which is beathach or ainmilidh), but something beyond an ordinary creature, a monster, a beast of prey. Thus, in the above instances, we believe it to have been derived from the mysterious and exaggerated recollection of the last solitary Bear which lingered in the deep recesses of the forest, the terror of the hunter and of the herdsman.

Thompson states that although he is not aware of any written evidence tending to show that the Brown Bear was ever indigenous to Ireland, a tradition exists of its having been so. It is associated with the Wolf as a native animal in the stories handed down through several generations to the present * "Lays of the Deer Forest," ii. p. 215.

$\uparrow$ Literally "the paw-calf," from màg, a paw, and ghamainn, it yearling calf. 'The name is now often corrupted into math-ghamainn the calf of the plain, which lias no meaning, for bears are not characteristically inhabitants of plains; but the implied allusion to the size and colour of a calf, with the distinction of the paw, is descriptive of the beast.

\# Traditions of this kind will be found in the story of "The Brown Bear of the Grcen Glen,' related in Campbell's "Popular Tales of the West Highlands," vol. i. pp. 164-170. 
time.* Sir William Wilde asserts that he discovered an Irish name for the Bear in an old glossary in the library of 'Trinity College, Dublin; and it is remarkable that the name to which he refers, "maghghamhainn" (corrupted into "math-ghamhainn," which, as already explained, conveys a different signification), is identical with the Gaelic name for the animal stil] preserved in traditions of the Highlands.

When the Bear became extinct in Britain is uncertain. Prof. Boyd Dawkins thinks it must have been extirpated probably before the tenth century. ${ }^{\dagger}$ The story quoted by Pennant + from a history of the Gordon family, $\S$ to the effect that in 1057 a Gordon, in reward for his valour in killing a fierce Bear, was directed by the king to carry three Bears' heads on his banner, is altogether a fallacy. Reference to a copy of the original Latin MS. from which the translation quoted by Pennant was made (preserved in the Advocates' Library, Edinburgh) shows that the animal killed was a Boar, "immanem aprum." Moreover, the arms of the Gordons happen to be Boars', not Bears' heads. The difference of one letter only in the name might easily account for a mistake which has been since blindly copied by many writers. As our ancestors, says Jamieson, called the boar bare, by a curious inversion the bear is universally denominated by the vulgar a boar.

* "Nat. Hist. Treland," vol. iv. p. 33.

+ "Cave Hunting," p. 75.

¥ "British Zoology," vol. i. p. 91 (ed. 1812).

$\S$ "The History of the Ancient, Noble, and Illustrious Family of Gordon." By William Gordon, of Old Alserdeen. 2 vols., Edinb., 1726. 
Col. Thornton, in his "Sporting Tour through the Northern parts of England and the Highlands of Scotland" (1804), states that on the island of Inchmerin, which is the largest island in Loch Lomond, being nearly two miles in circumference, beautifully wooded and well stocked with deer, Lord Graham had turned out a few wild Bears. Whether this is a misprint for Boar's, we have no means of knowing, but from the employment of the adjective "wild," this is probable, or he may have been misled by the Scottish pronunciation referred to by Jamieson.

When native Bears no longer existed, our ancestors imported foreign ones for a purpose that does no credit to the manners and customs of the times.

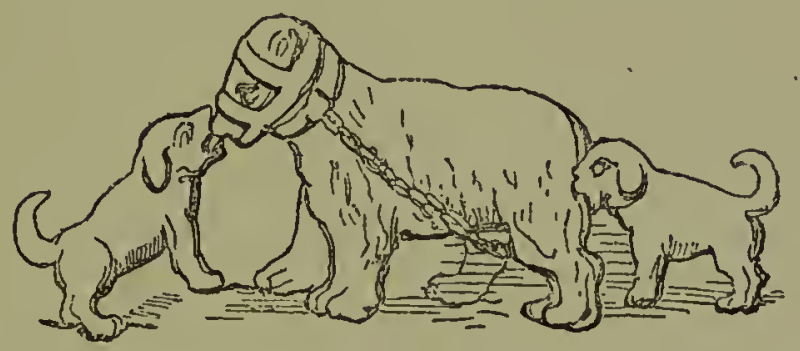

BEAR-BAITING, FROM A CARVED SEAT OF THE FOURTEENTH CENTURY, IN GLOUCESTER CATHEDRAL.

"Bear-baiting" in all its cruelty was a favourite pastime with our forefathers.

Fitz-Stephen, who lived in the reign of Henry II., tells us that in the forenoon of every holiday during the winter season the young Londoners were amused with Boars opposed to each other in battle, or with Bulls and full-grown Bears baited by dogs. There were several places in the vicinity of the metropolis set apart for the baiting of beasts, and especially the 
district of St. Saviour's parish in Southwark, called Paris Garden, which contained two Bear-gardens, said to have been the first that were made near London. In these, according to Stow, were scaffolds for the spectators to stand upon-an indulgence for which they paid in the following manner: "Those who go to Paris Garden, the Belle Sauvage, or Theatre, to behold Bear-baiting, interludes, or fence play, must not account of any pleasant spectacle unless they first pay one pennie at the gate, another at the entrie of the scaffold, and a third for quiet standing." * The time usually chosen for the exhibition of these national barbarisms, which were sufficiently disgraceful without this additional reproach, was the after-part of the Sabbath Day. One Sunday afternoon in January, I583, the scaffold being overcrowded with spectators, fell down during the performance, and a great number of persous were killed or maimed by the accident, which the Puritans of the time failed not to attribute to a Divine judgment. $\dagger$

Erasmus, who visited England in the time of Henry VIII., says there were many herds of Bears maintained in this country for the purpose of baiting. When Queen Mary visited her sister the Princess Elizabeth, during her confinement at Hatfield House, a grand exhibition of Bear-baiting took place for

* See also Strutt's " Sports and Pastimes."

† See Ficld, "A Godly Exhortation by occasion of the late Judgment of God shewed at Paris Garden, I 3 January, I 583, upon divers Persons whereof some were killed, and many hurt at a Bear-bating," \&c. I $2 \mathrm{mo}$, Lond. 1583 . 
their amusement, with which, it is said, "their highnesses were right well content." Queen Elizabeth, on the 25th of May, I559, soon after her accession to the throne, gave a splendid dinner to the French Ambassadors, who were afterwards entertained with the baiting of Bulls and Bears, the Queen herself remaining to witness the pastime until six in the evening. 'The day following, the same ambassadors went by water to Paris Garden, where they saw some more Bear-baiting. Some years afterwards, as we learn from Holinshed, Elizabeth received the Danish Ambassador at Greenwich, and entertained him with the sight of Bear-baiting, "tempered with other merry disports." Laneham, referring to some Bear-baiting which took place before the Queen at Kenilworth, in 1575 , says that thirteen Bears were provided for the occasion and that they were baited with a great sort of ban-dogs.* In these accounts we find no mention made of a ring put through the Bear's nose, which certainly was the more modern practice; hence the expression by the Duke of Newcastle in "The Humorous Lovers," printed in I6I 7 : "I fear the wedlock ring more than the bear does the ring in his nose."

The office of Chief Master of the Bears was held under the Crown, with a salary of sixteen pence a day. Whenever the Sovereign chose to be enter-

* " $\Lambda$ Letter: whearin part of the entertainment vntoo the Quecuz Maiesty at Killingworth Castl, in Warwick Shecr in the Soomerz Progress 1575 is signified." 
tained with this sport, it was the duty of the Master to provide bears and dogs, and to superintend the baiting. He was invested with unlimited authority to issue commissions, and to send his officers into every county in England, who were empowered to seize and take away any bears, bulls, or dogs that they thought suitable for the royal service. The latest record by which this diversion was publicly authorized is a grant to Sir Saunders Duncombe, dated October I I, I56I, "for the sole practice and profit of the fighting and combating of wild and domestic beasts within the realm of England, for the space of fourteen years."

The nobility also kept their "Bear-ward," who was paid so much a year, like a keeper, falconer, or other retainer. Twenty shillings was the payment made in 1512 to the "Bear-ward" of the fifth Earl of Northumberland "when he comyth to my lorde in Cristmas with his lordshippes beests for makynge of his lordship's pastyme the said xij. days."

The Prior of Durham, in 1530-1534, kept bears, and apes too, as we learn from an entry in the accounts of the bursar of the monastery, where the following entry occurs:-Et custodi ursorum et cimearum [simiarum] domince Principis, I Junii . . 5s.

A travelling "Bear-ward" depended entirely on his patrons. In the "Household Book" kept by the steward of Squire Kitson, of Hengrave, Suffolk, and commenced in 1572 , we find, under date July, I 574, the entry: "To a Bear man for bringing his Bears to Hengrave . . . . ij.s vjd." 
Paul Hentzner, who, in the capacity of travelling tutor to a young German nobleman, visited England in 1598 , has left a curious record of his journey in the form of an "Itinerary," preserved to us through the instrumentality of Horace Walpole.*

In this "Itinerary" the writer, after describing: the theatres (p. 269), particularly mentions another place, built in the form of a theatre, which served for the baiting of bulls and bears. "They are fastened behind," he says, "and then worried by great English bulldogs; but not without great risque to the dogs, from the horns of the one and the teeth of the other; and it sometimes happens they are killed upon the spot: fresh ones are immediately supplied in the place of those that are wounded or tired."

When any Bear-baiting was about to take place, it was publicly made known, and the "Bearward" previously paraded the streets with his animal, to excite the curiosity of the populace, and induce them to become spectators of the sport. On these occasions the Bear, who was usually preceded by a minstrel or two, carried a monkey or baboon on his back. In "The Humorous Lovers," the play above referred to, "Tom of Lincoln" is mentioned as the name of a famous Bear, and one of the characters, pretending to personate a "Bearward," says; "I'll set up my bills, that the gamesters of London, Horsly-

* "A Journey into England by Paul Hentzner in the year I 598." First printed in the year 1757, and cuntained also in Dodsley's "Fugitive Pieces," vol. ii. pp. 233-3I I (1765). 
down, Southwark, * and Newmarket may come in and bait him before the ladies; but first, boy, go fetch me a bagpipe; we will walk the streets in triumph, and give the people notice of our sport."

The two following advertisernents, published in the reign of Queen Anne, will serve as specimens of the manner in which these pastimes were announced to the public :-

"At the Bear Garden in Hockley-in-the-Hole, near Clerkenwell Green, this present Monday, there is a great match to be fought, by two dogs of Smithfield Bars, against two dogs of Hampstead, at the Reading Bull, for one guinea to be spent: five let-goes out of hand; which goes fairest and furthest in wins all. Likewise there are two Bear-dogs to jump three jumps a piece at the Bear, which jumps highest for ten shillings to be spent. Also a variety of Bullbaiting and Bear-baiting; it being a day of general sport by all the old gamesters; and a bulldog to be drawn up with fireworks. Beginning at three o'clock."

A second advertisement runs thus :-_"At William Well's Bear-garden in Tuttle Fields, Westminster, this present Monday, there will be a green Bull baited, and twenty dogs to fight for a collar'; and the dog that runs furthest and fairest wins the collar: with other diversions of Bull and Bear baiting. Beginning at two of the clock." +

* The Bear-garden at Southwark, with its "band-dogges or mastives," three of which were able to hold down a bear, is briefly alluded to by Camden, vol. i. p. 434 (ed. Holland).

+ Strutt's "Sports and Pastimes," p. 237. 
Sometimes as many as seven bears were exhibited at once, each confined by a long rope or chain, and baited with three or four large and courageous dogs, who rushed upon him with open jaws. The bears, ferocious and fretful with continued fighting, were of great strength, and not only defended themselves with their teeth, but hugged the dogi to death, or half suffocated them before their masters could release them. The bears generally bore the same names as their owners- "Hunx," "George Stone," "Old Harry of Tame," and "Great Ned," were well-known public charcteters, and Shakspeare alludes to one named "Sackerson."

Sometimes the bear broke loose, to the terror of women and children. On one occasion a great blind bear broke his chain, and bit a piece out of a servingman's leg, who died of the wound in three days. On such emergencies a daring gallant would often run up and seize the furious beast, entangled as he was with dogs, and secure him by his chain. It was to an exploit of this kind that Master Slender referred when, boasting of his prowess to Mistress Anne Page, he said:- "I have seen 'Sackerson' loose twenty times, and have taken him by the chain; but, I warrant you, the women have so cried and shrieked at it, that it passed: but women, indeed, cannot abide 'em ; they are very ill-favoured rough things."-Merry Wives of Windsor, act i. sc. I.

Shakspeare has drawn not a few illustrations and metaphors from this rude sport. In another place he speaks of the bearward's bears frightening 
the fell-lurking curs by the mere shaking of their chains, and describes a hot o'erweening cur ruming back and biting his owner, who withheld him, yet when suffered to get within reach of the bear's fell paw, clapped his tail between his legs and howled.Second Part of ITenry VI. act v. sc. I.

The noise of the bear-gardens must have- been well-nigh unendurable, what with the din of men eager to bet on their favourites, and the loud shouts of the respective partisans of $\mathrm{dog}$ and bear. At the present day the comparison of a noisy house to a "bear-garden" still perpetuates the national amusement of our forefathers.

Happily, such pastimes have long been obsolete, although the memor'y of these bygone days is still occasionally revived by an attempted exhibition of a tame performing bear.*

* Singularly enough while these pages were passing through the press the daily papers of August II, I880, furnished a report of a summons which had just been heard by the magistrate at Greenwich against two Frenchmen who had bcen brought before him "charged with exhibiting a bear in the streets, to the danger of the public." A constable stated that on the afternoon of the previous day he was on duty at Rushey Green, Lewisham, when a party of ladies drove up in a carriage and said that some men were performing with a strange animal at Catford Bridge, and that their horse would not pass it. He went to the bridge, where he saw the two Frenchmen with a bear, which was dancing, turning summersaults, and climbing a pole. $\mathrm{He}$ told them that sucl cxhibitions were not allowed in the public streets, and on their continuing the performance he took them into custody. The magistrate told the men that if they would at oncc leave the country with the bear, he would let them go. They gave the desired promise, and wcre accordingly discharged. 


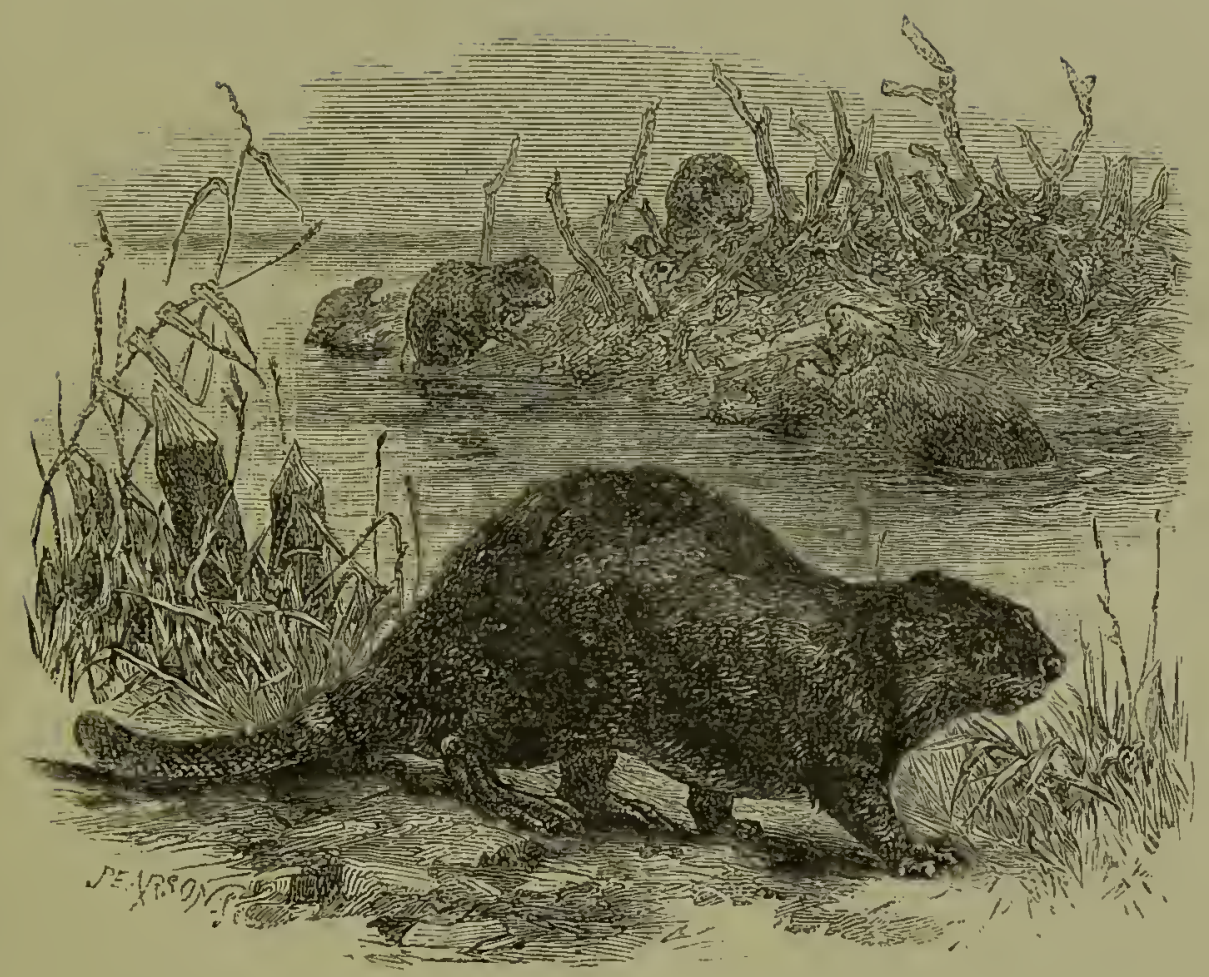

\section{THE BEAVER,}

Castor fiber.

THere is no reason to doubt that, within historic times, the Beaver was an inhabitant of Britain, although, like the Bear, the Wolf, and the Wild Boar, it has long been exterminated before the advance of civilization.

The earliest notice we find of it is contained in the code of Welsh laws made by Howel Dha (A.D. 940), and which, unlike the ancient Saxon codes and the Irish Senchus Mor, contains many quaint 
laws relating to hunting and fishing. It is there laid down that the king is to have the worth of Beavers, Martens, and Ermines, in whatsoever spot they shall be killed, because from them the borders of the king's garments are made.

The price of a Beaver's skin, termed "croen llostlydan," at that time was fixed at I 20 pence, while the skin of a Marten was only 24 pence, and that of a Wolf, Fox, and Otter 8 pence. This shows that even at that period the Beaver was a rare animal in Wales.

The superior warmth and comfort which the Beaver's skin affurded, added to the reputation of the medicinal properties of the castor, must have operated as a very powerful incitement to hunt the Beaver in those early times. We must, therefore, refer the period of their abundance in this country to an age much earlier than that of Howel Dha, the period, perhaps, before the Britons were driven from the more southern parts of Britain into the wilds of Cambria by the Romans, Danes, and Saxons, and when the mountainous wilds of Wales were almost unreclaimed from a state of Nature by the hand of cultivation. At such a time, it is very likely, the Beavers were numerous in many of the mountain streams and pools, but after the defeat of Vortigern, who settled with a remnant of his scattered Britons among these mountains, it is easy to conceive the Beaver would be sought for by the hunters, perhaps for the sake of food, and certainly for its fur; so that after the lapse of some centuries which passed 
before the time of Howel Dha, its numbers would be progressively diminished, and that very considerably. There still remained, however, extensive wastes in Howel's time, for it was among the laws of that prince that every man was entitled to so much land of that kind as he should bring into cultivation. We cannot imagine, therefore, that the Beaver was unable to find a secure retreat among the valleys of these barren mountains, the hills of Snowdon.*

Howel Dha died in the year 948; the travels of Giraldus de Barri-or, as he is generally styled, Giraldus Cambrensis-did not take place till about two hundred and fifty years afterwards ; it cannot, therefore, excite surprise that the Beaver had then become scarce and local, since we have seen the value attached to its skin, and established by law between two and three centuries before that time.

In his quaint account of the journey he made through Wales in I 88 , in company with Baldwin, Archbishop of Canterbury (who afterwards fell before Acre in the train of Richard Cour de Lion), Giraldus tells us that the Beaver was found in the river Teivi in Cardiganshire, and gives a curious account of its habits, apparently derived in some part from his own observation. $\dagger$

Harrison, in his description of England prefixed to Holinshed's "Chronicles," remarks: "For to saie

* Donovan, "British Quadrupeds."

† "Itinerary," ed. Hoare, vol. ii. p. 49. 
the truth we have not manie Bevers but onelie in the Teifie in Wales."* The precise spot on the river appears to have been Kilgarran, which is situated on the summit of a rock at a place called Canarch Mawr (now Kenarth), where there is a salmon leap.

Drayton, in his "Polyolbion" (song vi.), has thus versified the tradition :-

More famous long agone, than for the salmon's leap, For Beavers 'Tivy was, in her strong banks that bred, Which else no other brook of Britain nourished:

Where Nature in the shape of this now perish'd beast Her property did seem to have wondrously exprest.

There is some reason for supposing, however, that there were other rivers in Wales, besides the Teivi, which were frequented by these animals. "In the Conway," says Camden, "is the Beavers' pool," and a portion of the river bank above Llanwrst is supposed to have been a Beavers' dam.

Sir Richard Colt Hoare, in his edition of the "Itinerary" of Giraldus, remarks: "If the Castor of Giraldus, and the Avanc of Humphrey Llwyd and of the Welsh dictionaries, be really the same animal, it certainly is not peculiar to the Teivi, but was equally known in North Wales, as the names of the places testify. A small lake in Montgomeryshire is called Llyn yr Afangc; a pool in the river Conway, not far from Bettws, bears the same name (the Beavers' Pool); and the name of the vale called Nant Ffrancon, upon the river Ogwen, in Caernar-

* Holinshed's "Chronicles," vol. i. p. 379. 
vonshire, is supposed by the natives to be a corruption from Nant yr afancwm, or the Vale of the Beavers."

Owen, in his Welsh Dictionary (I 801), says that it has been "seen in this valley within the memory of man;" but says Sir Richard Hoare, "I am much inclined to think that 'Avanc' or 'Afangc' is nothing more than an obsolete or perhaps local name for the common "Otter, an animal exceedingly well known in all our lakes and rivers, and the recognition of it by Mr. Owen considerably strengthens my supposition. Afancwm is evidently the plural of Afangi, composed of the words Afan, a corrupt pronunciation of $A$ fon (a river), and $C i$ (a dog), synonymous, as I conceive, with Dyfrgi (the water-dog), which is the common appellation of the Otter amongst the Welsh. The term 'Llostlydan,' or broad-tail, from Llost (tail) and Llydan (broad), appears to be more immediately applicable to the character of the Beaver as described by naturalists, and is equally authorized by the Welsh Dictionaries, though not so often used as Afangc." **

Upon this we would remark that, while it is pretty certain that the animal seen, according to Owen, "within the memory of man," was the Otter, the minute description given by Giraldus shows that the animal to which he referred was the Beaver.

Describing the river Lleder at its junction with the Conway, Wood says : $†$ - "From a more westerly course the Conway here turns nearly due north, and

* "Itinerary," ed. Hoare, vol. ii. pp. 55-57.

† "The Principal Rivers of Wales Illustrated." 4to, 1813, part ii. p. 239 . 
exhibits the most enchanting views, in which the grand features of the mountains are most happily blended with the softer woodland scenery of the vile. On either side the river, rude rocks rear their naked heads, a scanty covering of underwood commences half way down, which, increasing as it descends, intermixed with rock, clothes the bottom through which the river winds. In the midst of this luxuriant wood, a stone bridge of one large arch is seen crossing the stream. This bridge is called Pont Llyn ar Avangc, or the Bridge of the Beavers' Pool, from its situation at the head of a deep pool in the river Conway, in old times frequented by those animals." He adds, "One part of Nant Francon is named Sarn ar Avangc, or the Beavers' Dam: and it is improbable that a people would not only have a name for an animal in their language, but actually assign the places frequented by them, unless such animal had existed in that country."

Amongst the Welsh historians, Sir John Price and Humphry Llwyd have both noticed the former existence of the Beaver in Wales. The firstnaned of these authorities, Sir John Price, is the author of a description of Cambria that is usually found annexed to the History of Wales, continued from Caradoc of Llancarvon, the contemporary of Geoffrey of Monmouth. This description of the Cambrian principality by Sir John Price was written in the time of Henry VIII., and was afterwards augmented by Humphry Llwyd, Gent., of Denbigh, who died in I 568. The work in consequence did not 
appear till the time of Queen Elizabeth, when an English translation of it was inserted by Dr. Powel, in his "History of Wales," published in 1588 . We are thus minute in describing the circumstance, because the passage we are proceeding to notice has been attributed to Dr. Powel, while from the preceding observations it will appear to be really the writing of a much earlier author. The passage is as follows :"Káorwp Greek, Fiber Latin, Beaver English, Afanc British. Giraldus in Itinerarium."

"In Teivi, above all the rivers in Wales, were in Giraldus's time a great number of Castors, which may be Englished Beavers, and are called in Welsh avanc, which name onelie remaineth in Wales at this date, but what it is very few can tell. It is a beast not much unlike an Otter, but it is bigger, all hearie saving the taile, which is like a fishe taile, as broad as a man's hand. This beaste useth as well the water as the land, and hath very sharp teeth, and biteth cruellie till he perceive the bones cracke."

After mentioning the efficacy of the secretions of this animal in physic, the writer proceeds: "He that will learn what strong nests they make, which Giraldus calleth" castells, which they build upon the face of the water with great bows (boughs) which they cut with their teeth, and how some lie upon their backs, holding the wood with their fore feet, which the other draweth with a crosse stick, the which he holdeth in his mouth, to the waterside; and the other particularities of their natures, let him read Giraldus, in his Topographie of Wales." 
After stating that the T'eivi was the only river in Wales, or even in England, that had Beavers, Giraldus remarks: "In Scotland they are said to be found in one river, but are very scarce." Hector Boece (or Boethius), that shrewd old father of Scottish historians, writing in I 526 , enumerates the Fibri, * or Beavers, with perfect confidence, amongst the ferce naturce of Loch Ness, whose fur was in request for exportation towards the end of the fifteenth century, and he even speaks of "an incomparable number," though perhaps he may be only availing himself of a privilege which moderns have taken the liberty of granting to mediæval authors when dealing with curious facts. Bellenden, in his vernacular translation of Boethius' "Croniklis of Scotland," which he undertook at royal request in I536, while omitting stags, roe-deer, and even otters, in his anxiety for accuracy, mentions "Bevers" without the slightest hesitation; and, though exception may be taken to the first clause of the sentence, yet the passage is worth quoting: "Mony wyld Hors and amang yame are mony Martrikis [pine martens], Bevers, Quhitredis [weasels], and Toddis [foxes], the furrings and skynnis of thayme are coft [bought] with great price amang uncouth [foreign] merchandis."

More than a century later, Sir Robert Sibbald was unable to say that the Beaver still existed in Scotland. In his "Scotia Illustrata," published in I684, he

* Fibri, from Fiber, denoting an animal that is fond of the fibrum or edge, of the water. 
remarks (par. iii. cap. v.), "Boethius dicit Fibrum seu Castorem in Scotia reperivi, an nunc reperiatur nescio."

It is more than probable, says Dr. Robert Brown, that the worthy historians were influenced by a little of the natural pride of country-the "perfervidum ingenium Scotorum "-when they recorded the Beaver as an inhabitant of Loch Ness in the fifteenth century, since no mention is made of it in an Act of Parliament dated June, I424, although " mertricks, foumartes, otters, and toddis" are specified. They were perhaps so strongly impressed by the widespread tradition of its existence in former days as to lead them to enumerate it among the animals of Scotland, and it may be observed that the authors quoted boast immoderately of the productions of their country. At the beginning of the century (at least) the Highlanders had a peculiar name for the animal -Losleathan* or Dobhran losleathan, the Broadtailed Otter; and, according to Dr. Stewart of Luss, in a letter to the late Dr. Patrick Neill, Secretary of the Wernerian Society of Natural History, a tradition used to exist that the Beaver, or Broad-tailed Otter, once lived in Lochaber.

Of the Beaver in Scotland, says Stuart, $\uparrow$ there is later testimony than of the Bear. Like that animal, it has left in its radical Gaelic name, Dobhar-C'hu, $\neq$

* Compare the Welsh Llostlydan.

† "Lays of the Decr Forest," vol. ii. p. 216.

¥ In the modern confusion of obsolete terms, this name is sometimes confounded with that of the Otter, which is Dolhar-an.-Stuart, op. cit. 
the water-dog, an evidence of its aboriginal nativity in Scotland; and its existence in Britain is noticed in a romance not anterior to the twelfth century, * which the materials were probably derived from Wales.

It must be confessed that the written records we have of its occurrence are very fragmentary, and not wholly satisfactory; but abundant evidence of its former existence in this country at a date long anterior to these historical notices is supplied by the remains of the animal which have been exhumed in various places, both in England and Scotland.

In the third volume of the "Memoirs of the Wernerian Nat. Hist. Society" (I82 I, p. 207), is an account by the late Dr. Neill of some remains of Beavers found in Perthshire at the Loch of Marlee, Kinloch, and in Middlestots Bog, Kimmerghame, in Berwickshire. Another skull exhumed at Linton, in Roxburghshire, is preserved in the Museum at Kelso. + Other remains of Beavers, considered to be identical with the species found in North America at the present day, have been discovered at Mundesley, Bacton, and Happesburg, Norfolk, in the fluvio-marine crag near Southwold, Suffolk, in the peat near Newbury, $\$$ and in the Thames Valley at Crossness Point, near Erith. ॥

* Fragment of the "Romance of Sir Tristram," MS. in the Donce Collection, No. 2.

+ See, also, Dr. C. Wilson, 'On the Prior Existence of the Castor' fiber in Scotland,' Edinb. New Phil. Journ., 1858, N.S., vol. viii.

\$ "Proc. Berwicks. Nat. Club," vol. ii. p. 48.

$\S$ Collet, "Phil. Trans," r 757, p. r I2.

I| Boyd Dawkins, Popular Science Fievieiv, 1868, 1. 39. 
The species has also occurred in a semi-fossil condition in Cambridgeshire, ${ }^{*}$ and at one time, it would seem, this animal must have been common in the eastern counties of England. Mr. Skertchley, in his remarks on the prehistoric fauna of the Fens, $\uparrow$ says, "The remains of the Beaver are tolerably abundant in the Fens ;" and further on he adds: "So far as my observation goes, the Beaver did not build dams in the Fens, owing, in all probability, to the abundance of still water. The late J. K. Lord, an experienced trapper, remarked that in North America the Beaver only constructs dams in running streams, and chooses still water where possible, to save the labour of architecture."

Mr. Henry Reeks, however, writing in December, 1879, states that if such is the case it is utterly opposed to the habits of these animals as observed by him in Newfoundland. He says "Newfoundland is a vast lake district, abounding in ponds and lakes, from a few hundred yards to many miles in length and breadth ; Beavers also are still plentiful there. It is, however, a fact that out of the hundreds of Beavers' houses I saw there, none were built in ponds or lakes, but invariably on the brooks running into or from the lake. From my own observations, I do not think it would accord with the economy of the Beaver to build a house in still water, especially in countries like Canada and Newfoundland-where, during the winter, there would probably be an

* Jcnyns' "British Vertebrate Animals," p. 34.

† "The Fenland, Past and Present," p. 348. 
average of five feet of snow on the ground (although, of course, not evenly distributed), which means a rise of at least two feet of water in the ponds and lakes at the break-up of winter. How then would a Beaver manage this superabundance of still water? You will probably say "that's best known to the

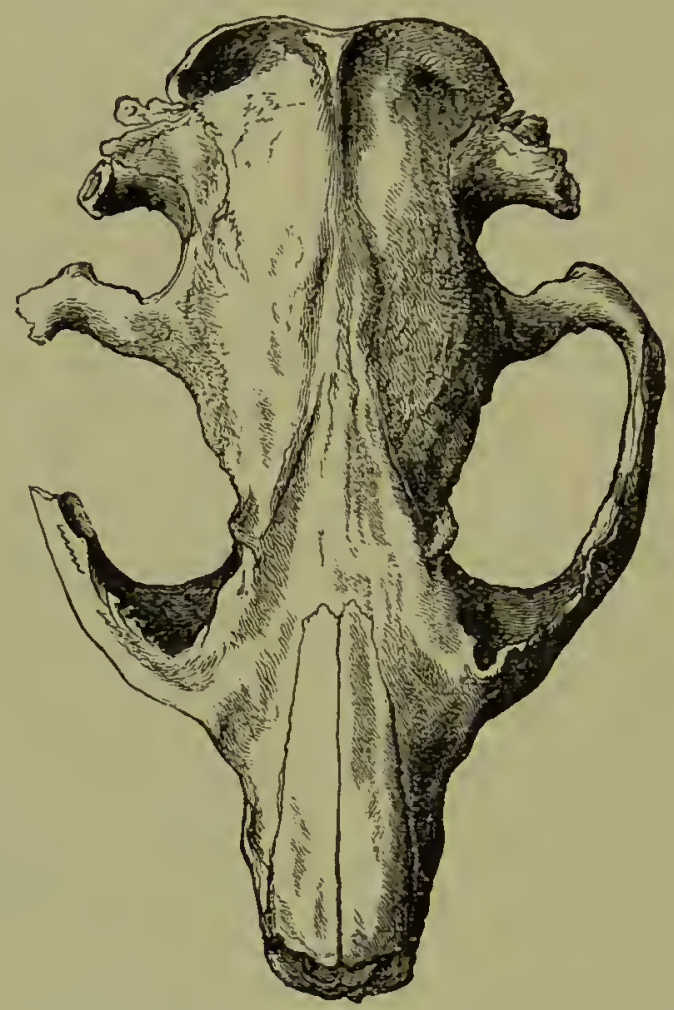

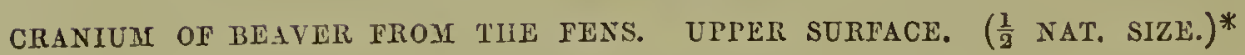
Beaver himself!" Just so ; but we know what a Beaver does under similar circumstances when he has built his house and dam on a running brook. During the summer months Beavers often frequent ponds and lakes at a distance from their houses for the purpose of feeding on the stems and roots of a pond lily (Nuphar advena). When a Beaver's house

* From a specimen in the Museum of the Royal College of Surgcons. 
is placed on the margin of a lake, I think it will invariably be found to be at the mouth of a small brook running out of the lake, and vice versâ."

Pennant, or rather his editor, refers to a complete head of a Beaver, with the teeth entire, which was found in the peat at Romsey, Hants,* and Mr. F.

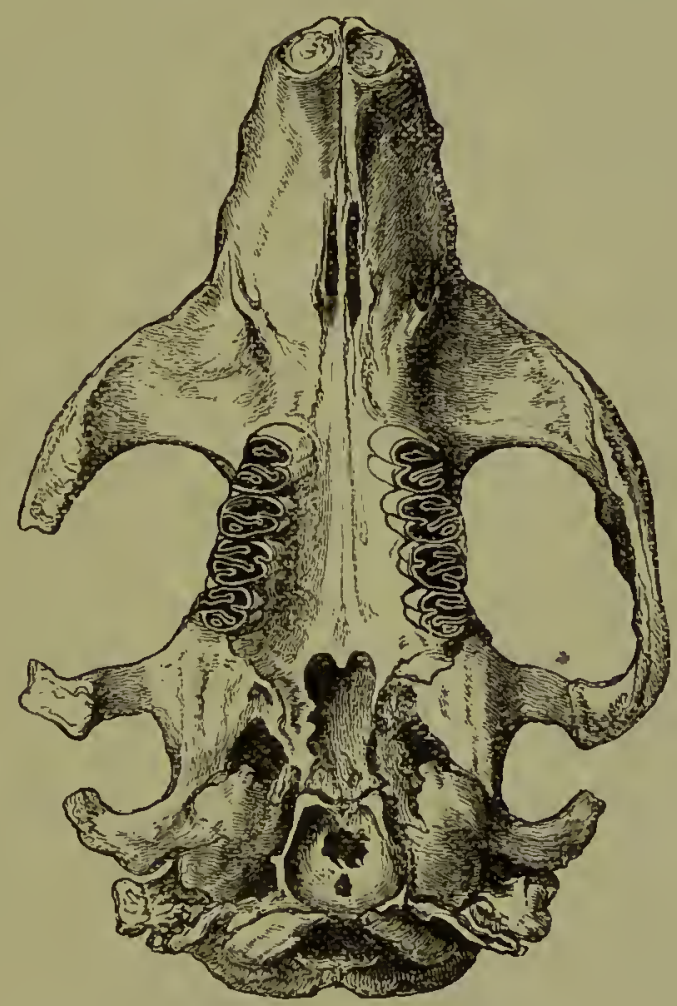

CRANIUM OF BEAVER FRON THE FENS. UNDER SURFACE. ( $\frac{1}{2}$ NAT. SIRE).

Buckland has a fine specimen of a Beaver's jaw, which was dug up in a fen in Lincolnshire; various portions of the skeleton have been discovered in Kent's Hole, Devonshire, the only British cave which has yielded the remains of this animal. $\dagger$

* "British Zoology," vol. i. p. 6o, note (ed. 1812).

+ Pengelly on the Ossiferous Caverns of Devonshire, "Report Brit. Assoc. I 869," p. 208, and I 877 , pp. I-8. 
Fossil remains of an extinct Beaver, closely allied to, but much larger than, the existing species, have been found in the Norwich crag at Cromer. Prof. Owen has described it under the name Trogontherium Cuvieri.*

The town of Beverley, in Yorkshire, is said to have derived its name from the number of Beavers found in the vicinity, when in the eighth century (about 7 ro) St. John of Beverley built his hermitage there, the foundation of the town. The stream on which the town was built was then called in AngloSaxon "Beofor-leag," or "the Beavers Lea;" but this has become softened down into its present pronunciation and spelling. "The town," says Leland, "hath yn theyr common seal the figure of a bever." + Other places in England also seem to indicate by their names the ancient haunts of this animal, as Beverege (Worcestershire), and Berere Island, formed by the Beverburn or "Barbon" (two miles north of Worcester), Bevercotes (Nottinghamshire), Beverstone (Gloucestershire), and Beversbrook (Wiltshire).

The lately-attempted re-introduction of the Beaver into Scotland by the Marquis of Bute deserves some notice here.

In a solitary pine wood near Rothesay, in the Isle

* "British Fossil Mammals," p. I84.

+ Other authorities, horvever, suggest a different derivation-e.g., in Phillips" "Yorkshire" (2nd ed. p. 105) we read: "At Beverley was the shrine of St. John, preceded by an earlier settlement marked by four stones, from which we infer that it was the British Pedwarllech, and Greek Pctonar, chief city of the Parisoi, as it still is of the East Riling. From Pedruarllech we have Bevorluc, Beverley." 
of Bute, a space of ground has been walled in so that the Beavers cannot escape, and through this Beaver's park runs a mountain stream. Left to themselves, they have quite altered the appearance of this stream, for they have built no fewer than three dams across it; the lowest is the largest and most firmly constructed, as it would seem the Beavers were fully aware that it would have to bear the greatest pressure of water. In order to strengthen this dam, these intelligent animals have supported the downstream surface of it with props of strong boughs, as artfully secured as though a human engineer had been at work. Immediately above this the Beavers have constructed their hut or home, consisting apparently of a large heap of drift wood; upon examination however, it appears that the sticks have been placed with regularity and order, so that the general appearance of the hut is not unlike that of a bird's nest turned upside down. The Beavers have cut down a good many trees in their park, gnawing a wedge-shaped gap into one side of the tree until it totters, and then going round to the other side and gnawing the only portion of wood which prevents it from falling. If the felled $\log$ is too heavy for transport, they cut it into pieces, which they roll away separately. Although there have been one or two deaths, it is satisfactory to learn that these Beavers have bred in the island since their introduction. In December, 1877 , there were twelve known to be alive. They were reported to be very shy, retiring into their hut, or into the water, at the least 
alarm. Besides the vegetable food they pick up, they are fed principally with willow boughs, the bark of which they are said to strip off with the neatness of a basket-maker.

Mr. Charles Hockin, who spent a fortnight, during the summer of 1879 , at the primitive little village of Kilchattan Bay, in the Isle of Bute (which is only about a couple of miles from the Marquis of Bute's Beaver ponds), has been kind enough to supply us with the following account of his visit :-

" The Beavers have, I am informed by their keeper, increased considerably in number during the last few years, and numbered in 1878 about twenty-seven or twenty-eight, and there are, it is believed, eight or ten more this year; certainly, judging by their works, they are increasing. They have now five or six weirs, or dams, across the stream, of which the second largest was partially carried away by the floods of the late spring, and now displays, in its section where cut off by the water, the wonderful cleverness of these interesting little engineers.

"The largest dam they have constructed is about a hundred and twenty feet in length, and gives a depth of water in the pond above it of some eight or nine feet. It is arched against the stream in a manner showing almost human ingenuity, taking advantage of one or two trees, which originally must have stood on the very edge of the stream (a mere rivulet); it is built up of logs varying from two to four feet in length, and from one to four or five inches in diameter, worked together and filled in with mud, and 
measures some eight or ten feet thick at the base, and about two feet at the top.

"The house which they have built for themselves is constructed of similar materials, and presents a dome-shaped top of about ten feet in diameter, rising some two or three feet above the water. There are two entrances or doors to the house, both being at the bottom of the water, and an air-hole or ventilator is left at the top, protected with sticks or $\operatorname{logs.}$

"In addition to the house, they have constructed several burrows, which, entering the ground under water, run into the bank for three or four yards, and are provided with a ventilator similar to that in the house.

"The largest pond, that in which the house is placed, is about thirty yards long by ten or twelve yards wide at the widest, the dam inclosing a little bay or inlet at one end, thus accounting for its extra length.

"It is very wonderful to observe the manner in which these little workmen fell trees (some of them upwards of two feet in diameter), and almost invariably bring them down so as to fall directly towards the water, thus giving them a shorter distance to drag the bark and branches when lopped off; and it is only when a tree, being nearly cut through at the base, succumbs in a storm coming from a wrong direction, or when, as it occasionally happens, they themselves wish it otherwise, that they fail to bring the trees down directly towards 
the stream. There is one instance of this latter fact which is very difficult to explain. A tree of about a foot in diameter grew close to the base of one of the dams, leaning at a considerable angle over the dam, and this, for some reason best known to themselves, they had left standing long after they had cut down trees at a considerable distance from the stream; but last spring they started to cut it down, and down it came-not, as it would be supposed, in the direction in which it leaned (which would have brought it right across the dam), but backwards from the water, and nearly exactly in a contrary direction from that in which it grew. How this was done I do not pretend to say, nor why, for it was not of the description of tree on which they feed (mostly Scotch fir); but there it lay, having been down some months, with all its bark on and the branches not lopped off, clear of the dam and stream.

"The mode of felling trees is very interesting; their teeth cut as clean and sharp as a chisel, and the modus operandi (as seen by the keeper in his moonlight watches) is, a cut above and a cut below, a wrench, and out comes the chip. They appear never to work more than one at a time at each treei.e., so far as the cutting down is concerned-and to relieve one another at regular intervals, all work being done at night or in the very early morning. Two or more will join together to drag or roll a $\log$ to the water which is too heavy for one to manage, and the bark is always stripped off and stored under water for winter consumption, before the branches 
are cut into lengths and carried off for building purposes.

"The story that Bearers use their broad flat tails as a 'trowel' for plastering' purposes is said by the keeper' (who has spent a very great deal of time in watching their habits, getting up into a tree before dark, and sitting there without sound or motion for hours and hours) to be a myth. He describes the process of plastering as follows: The Beaver swims away from the dam or house upon which it is at work for some distance, then dives, and emerges

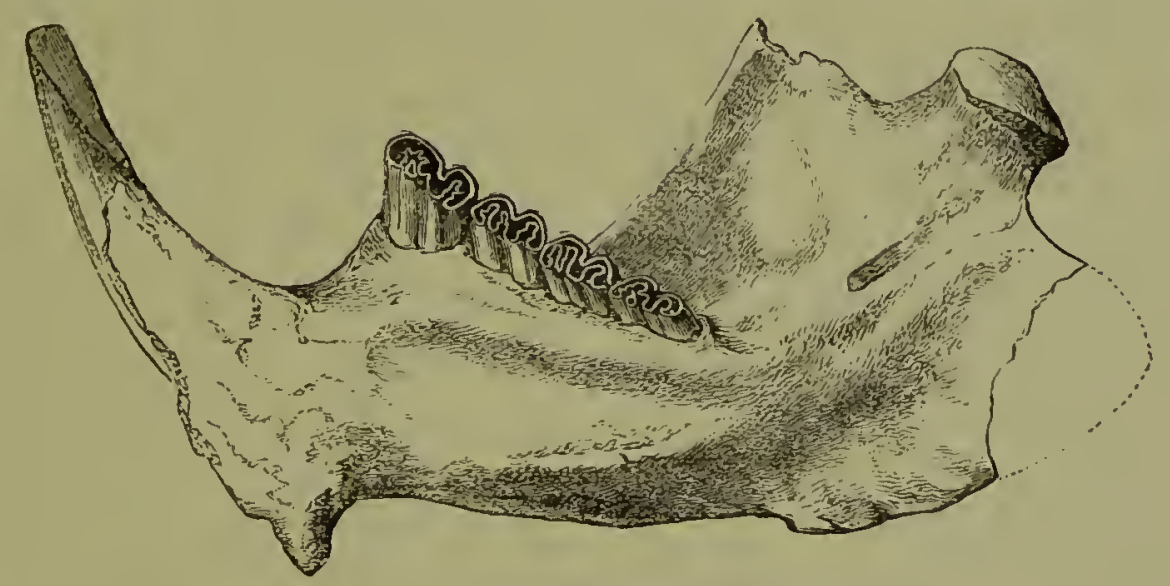

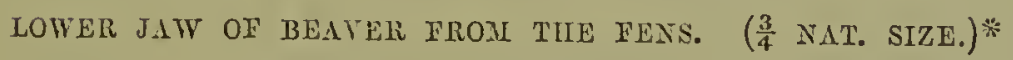

again close to the diam or house, carrying the mud in its mouth. It then places it where required, and proceeds to knead it with its forefeet; and when one considers the enormous amount of work entailed in thus plastering a dam of 8oft. or 1ooft. long; Ioft. to $15 \mathrm{ft}$. thick at the base, and $8 \mathrm{ft}$. to Ioft. high, it makes one wish that our human workmen would display a little more of the indomitable perseverance shown by these wonderful little creatures.

* From a specimen in the Museum of the Royal College of Surgeons. 
"They are remarkably shy of anything luman, and upon the least alarm 'flop 'goes one of the flat tails upon the water, and 'presto!' not, a Beaver is to be seen.

"They feed mostly on the inner bark of the Scrotch fir, great quantities of which they store under water near their honse; they also eat the younger shoots of the bracken fern, and one or two smaller shruhs of which $I$ do not know the names. They are also very fond of the bark of young willow shoots, which the keeper supplies them with from time to time in the winter."

Since the date of Mr. Hockin's visit the keeper who has charge of these Beavers, Mr. J. S. Black, has published a most interesting account of them in the Journal of Forestry, for February, 1880, which we cannot do better than quote in extenso. He says:"In I 874, the Marquis of Bute having obtained four beavers, caused a space of from three to four acres in extent to be enclosed in the wood between Meikle Kilchattan and Drumreach, and placed them there. These not succeeding, his lordship, on 6th January, I 875 , obtained seven others. Of these, four succeeded so well that in 1878 I was certain of sixteen being alive, which makes an average increase of four each season. There is a further increase this season, but to what extent I cannot say.

"Arriving as they did in midwinter, these little

* 'A Short Account of hor the Marquis of Bute's Beavers have succeeded in the Isle of Bute, Scotland.' By Joseph Stuart Black, Kceper, Bute Estate. 
animals, I can assure you, had a pretty hard time of it. However, after a few days' rest, having viewed the situation, they set vigorously to work to make themselves comfortable, and began to construct a dam by forming a dyke or embankment across a small moorland stream running through the enclosure; at the same time they commenced to build a house to live in.

"The materials of which the dyke is constructed are wood, grass, mud, and a few stones which are used for the purpose of keeping the grass and smaller pieces of wood in their place until more is built on the top of them. They have continued raising this embankment to a certain extent every year, until it has now attained the following dimensions, viz. :- length, seventy feet; height in the deepest part, fully eight feet; breadth of base at deepest part, from fifteen to twenty feet, sloped inside, not straight across, but finely arched against the stream, so that it may the more easily resist the great pressure of water which it has to bear ;--perfectly level, so that when a spate of water comes down it may run evenly over the top from side to side. So substantially have they built it, that no material damage has occurred to it from all the floods that have passed over it. They use a number of the larger pieces of wood as props, by fixing the thick end into the ground and the small end on the top, then build on the top of these, so as to fix them firmly. It would require to be seen to appreciate the great skill displayed in its construction; as I think it would tax the energies of a Bateman or a Gale to make a better with the 
same materials. If any damage does occur, they inmediately find it out and repair it. I have seen them swim along the edge of the embankment, carefully examining it to ascertain the part most needful of repairs, then go to work with a will to rectify it. 'The dam is now seventy-eight yards long of still water.

"Besides the dam already mentioned, upon which they bestow great care in its construction, owing to the house being built in it, they have other seven, some larger, some smaller; one of them having an embankment ro5 feet long, and an average deptli of three feet. 'These serve as places of refuge if the beavers are disturbed when out roaming about in quest of food or felling the trees, also as a waterway for conveying their food by when storing it for winter.

In the construction of their dwelling the same kind of materials are used. As to how they built it: you must understand that for a considerable distance along one side of the stream, or burn, the ground rises in a steep bank, but about twenty yards above where they began to build the embankment for the dam there was a small level spot which they selected. Then at the bottom of the water they burrowed in three or four feet, rose up eight or ten inches, scooped out a space large enough to hold themselves, broke a liole in the surfuce about six inches in diameter, then began to cover it over with sticks, grass, and a few stones, always keeping it open in the centre by placing a few sticks perpendicularly, so as to act as a ventilator, and as the water rose in the dam and the family increased, they continued to 
build and enlarge the house, cutting their way up and forming their chamber or chambers inside, until it had now attained the following dimensions at the surface of the water (which is here about four feet deep), viz.:- -height about five feet, length and breadth about nine feet, having a door at both sides placed at the bottom of the water so as to prevent their natural enemies from following them, chief among which is the wolverine, although happily for both thern and us there are none of these here to disturb them.

"It is out of the water they take the materials with which they build their house. Were the sides of the house perpendicular they could not land; to obviate that difficulty they built a slip from two to three feet broad at its base, except where the doors are, so that they can land easily, and if they wish to enlarge the house they have got the foundation ready. To secure them against the winter storms, they commence about the middle of September and give their house a coat of mud all over. It is with the mouth and forefeet, which are formed more like hands than feet, that they convey the materials of which their embankment and house are made. They do not use their tail, as was at one time said, for plastering on the mud, but their forefeet, with which they very carefully stow it in among the sticks. As to what they use for a bed to lie on, it is wood shavings, which they prepare in the following manner. After using the bark for food, they then place the stick on end, holding it with both feet a bit apart 
then with their teeth pare it down into fine shavingss. They are very cleanly in their labits, as they often clean out their house, not casting away the refuse, but using it either on the top of the house or the embankment of the dam to patch up a hole.

"Their food in winter consists wholly of the bark of trees; had they a choice I have no hesitation in saying they would prefer the willow and poplar. These not growing in the enclosure they had just to adapt themselves to circumstances, and take a share of what trees they could get, consisting of oak, plane tree, elm, thorn, hazel, Scotch fir, and larch. Of the hardwood, they seem to prefer elm to plane tree, then oak, of which they eat sparingly. Of the firs, the Scotch has the preference; as for the larch they did not touch it till early in 1878 , since which time they have taken to it very well. As for the alder and spruce fir, they eat almost nothing of them. Along with all these, we have always given them a supply of willow. In summer they eat freely of the common bracken, likewise grass, and young shoots of every description growing in the place. In autumn they grub up and feed upon roots, chief among which is the tormentil (Potentilla tormentilla), better known to Scotch people as 'tormentil root,' and the young tender' shoots of the common 'spurts' before they appear above ground, at the same time cutting down a tree now and again and feeding on the bark.

"As to the tree-felling it is all done at night; the number which they have cut down amounts now to I 87 trees from five feet in circumference downwards. 
These are all forest trees, besides a great many smaller bushes. Before cutting down a tree, they mark it all round at the height at which they wish to cut it. They begin to cut at the opposite side to which they intend the tree shall fall, invariably making it fall with the top to the water. Where they grow near enough, they make them fall across the stream or dam, causing many to suppose that they are so placed to form a bridge, whereby they may cross from one side of the water to another. They do not require a bridge, they can swim, and rather than cross over a prostrate tree they dive under it. My impression is they are so placed to break the current of the water when the stream is flooded; also if convenient they take advantage of building a dam where some of the trees lie across the water. Those lying across in their principal dam are utilized in storing up their winter food, these stores being built on the upper side of the trees, so that they cannot be swept away with the winter flood.

"When cutting the trees they use their teeth, on the same principle that a forester does an axe, always keeping plenty of open space, so that they can cut past the centre of the tree on one side before beginning on the other. It is in the latter end of autumn they commence to cut down trees for winter food. Having cut them down, they speedily strip off the branches, cutting them into lengths to suit their strength for dragging them away to the dam, where they store them in different places near their house, so that they may have sufficient food, although the 
dam may be frozen over, or the ground covered with snow. What is left of the trunks of the trees that they cannot drag away, they feed on at leisure, eating the bark.

"Besides the work above ground which I have tried to describe, they have done a great amount of underground work, such as cutting channels in their dams, and making burrows. These burrows they make by cutting a road from the middle of the dam for several yards into the dry ground, where they scoop out a dome-shaped burrow from eight to ten inches above the level of the road, then cut a hole through the surface and cover it over with sticks and grass so as to act as a ventilator. Here they live and feed in security and contentment. Some of the roads to these burrows are from fifteen to twenty yards long, and so level that the water follows them in the whole length.

"As to the time they bring forth their young, from my own knowledge, I cannot say. I have seen it stated to be January, and also the beginning of May. I can say nothing against that, judging from the size of the young when I first saw them in the second week of June, the oldest litter being about the size of a full-grown rabbit, and the youngest not half that size.

"From careful observation, I have good reasons forbelieving they have only one at a birth. One thing I am certain of, they have two litters in the season. Beavers are a class of animals that are very timid, their sight, scent, and hearing very keen, so much 
so that it is with great caution they can be approached near enough to see what they are doing. They are under cover all day from seven o'clock in the morning till seven in the evening. When one comes out, it floats on the surface of the water, carefully surveying the whole scene around, snifting the air, and if no danger is apprehended it dives and disappears. In two or three minutes, a number of the colony begin to appear and disperse themselves, some to swim and sport about in the dam, while others go in quest of food. If one of thein espies danger it strikes one sharp, loud stroke on the water with its tail, when all of them that are out come tumbling into the dam and disappear.

"I have seen them wrestle in playfulness and fight in anger, and also when the mother was feeding and the young one sporting about in the dam, I have seen it go and begin to tease her, when, if she did not wish to be troubled with it she would strike and shake it, and pitch it from her in the dam. They will allow of no laziness in any member of the colony; if any such there be, they are beaten and driven out to live as best they may. These so driven out generally roam about, making a burrow here and there, where they live for a few months and die."

This is not the only experiment which has been made of late years in the reintroduction of Beavers into this country. A similar attempt was previously made in Suffolk. Some Beavers were turned down by $\mathrm{M}_{r}$. Barnes, of Sotherley Park, Wangford, and, on their dams being destroyed as an eye-sore, they 
strayed further down the stream which roms through the park. 'They were there two winters, and bred, having three or from young ones. Two of these, which strayed, were killed at Benacre in the spring of I 872 , and one was captured. They began to build a lodge in the West Bush against Benacre Broad, did no damage to trees, but destroyed some underwood. This third Beaver seems to have been also killed. 'T'wo of the three were sent to London to be stuffed for Lady Gooch, and the head-keeper tonk the skin of the third.

It is interesting to find that, but for the interference of man, Beaver's would still thrive in our climate, as we learn from geology and history they formerly did.

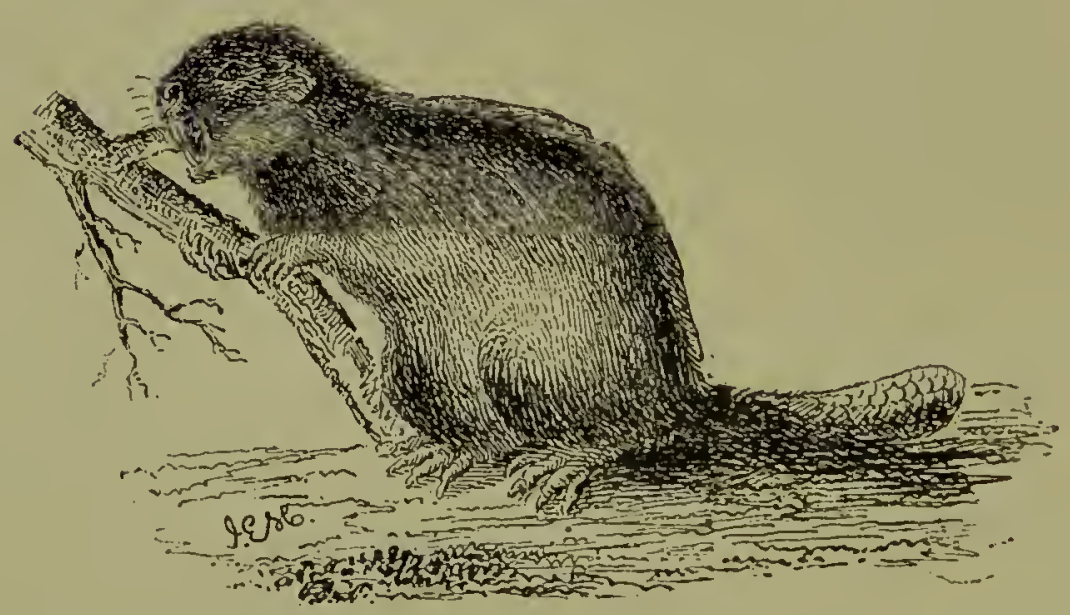

A BE.LVER AT WORK. 


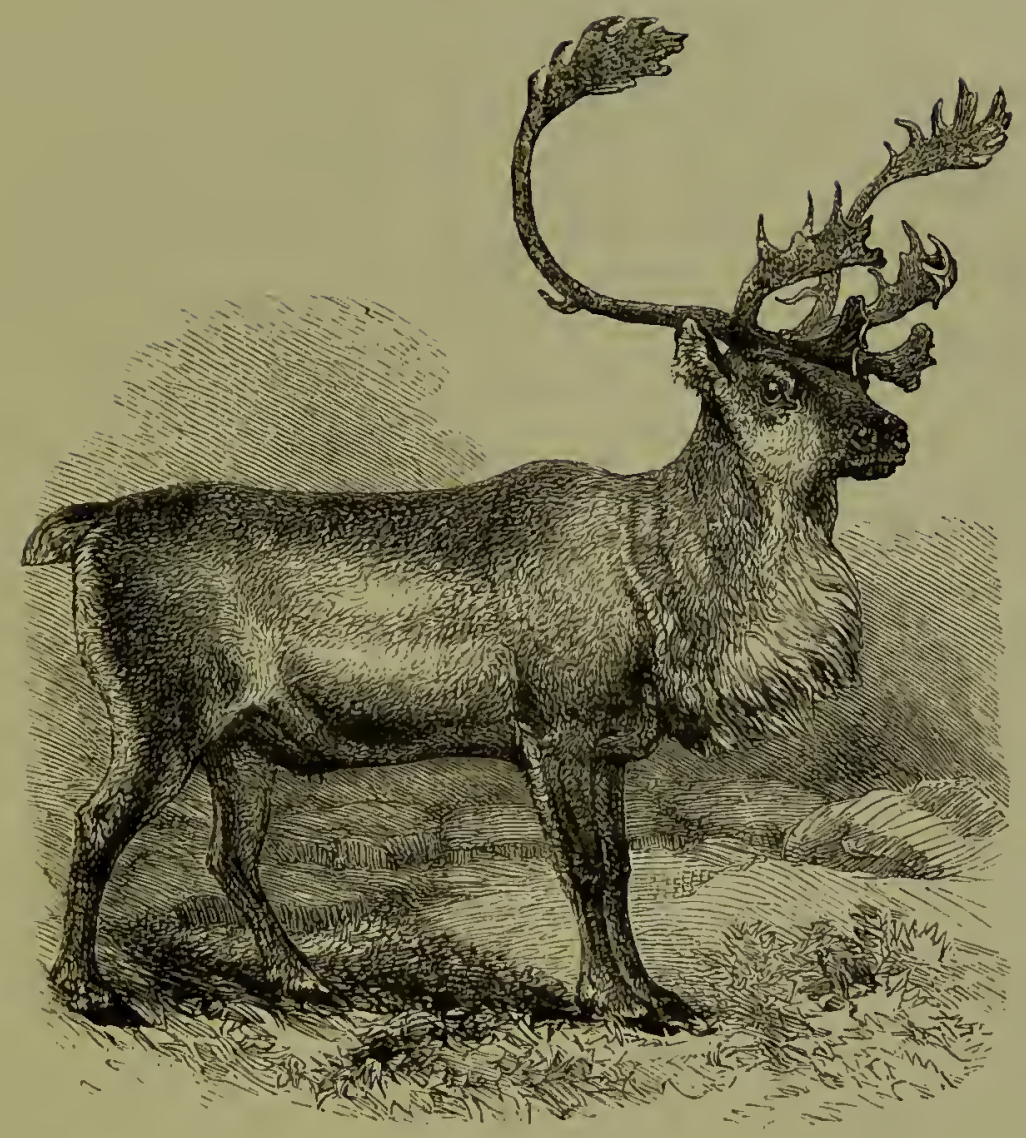

THE REINDEER.

Cervus tarandus.

ABout the time that the Bearer was building its dams on the rivers of Wales and Scotland, there was fast becoming extinct in North Britain another animal, whose singular form is perhaps better known than that of most animals, from its being amongst the earliest presented to youthful naturalists in their first zoological picture books-for who does not recollect the portrait of the Laplander with his Reindeer in a sledge? 
'This animal was one of the eirliest arrivals on British soil after the ice and snow of the glacial epoch began to disappear, and it is in caverns and river gravels and sands of post-glacial age that we first meet with its remains. Its abundance in British deposits of this date is very remarkable. Professor Boyd Dawkins has found portions of its bones and horns in no less than thirteen out of twenty-one caverns examined by him, while the Reddeer was only found in seven; thus, contrary to what is generally assumed to be the case, the Reindeer predominated in numbers over the Red-deer at the time the British bone caverns were being filled.

In the post-glacial river deposits the same numerical preponderance of the Reindeer is observed. It has been found in the gravels of Brentford, in a railway cutting at Kew Bridge, and higher up the Thames in a gravel bed at Windsor, where, in the spring of I 867 , numerous remains were discovered. On visiting the spot with the discoverer, Capt. Luard, R.E., Professor Boyd Dawkins found that more than one-half of the remains belonged to the Reindeer, the rest to Bisons, Horses, Wolves, and Bears. 'They had evidently been swept down by the current from some point higher up the stream.* In illustration of this accumulation he quotes a parallel case from the observations of Admiral Von Wrangel in Siberia, who remarks :†-"The migrating

* "Early Man in Britain," p. 155 .

† "Siberia and the Polar Sea," translated by Major Sabine, Sro, r $840, \mathrm{p}$. 190. The obviously exaggerated figures must be taken to represent the vast numbers of the animals. 
body of Reindeer consists of many thousands, and though they are divided into herds of two or three hundred each, yet the herds keep so near together as to form only one immense mass, which is sometimes from fifty to a hundred versts, or thirty to sixty miles, in breadth. They always follow the same route, and in crossing the river Aniuj, neir Plobischtsche, they choose a place where a dry ralley leads down to a stream on one side and a flat, sandy shore facilitates their landing on another. As each separate herd approaches the river, the deer draw more closely together, and the largest and strongest takes the lead. He advances, closely followed by a few of the others, with head erect, and apparently intent on examining the locality. When he has satisfied himself he enters the river, the rest of the herd crowd after him, and in a few minutes the surface is covered with them. Wolves, bears, and foxes hang upon the flanks and rear of these great migratory bodies, and prey upon the stragglers, and invariably many casualties occur at the fords where the weak or wounded animal is swept away by the current."

A graphic account is given, by the same author, of the migration of Reindeer as observed by him in his journey through the stony Tundra, near the river Baranicha, in north-eastern Siberia.

"I had hardly finished the observation," he writes, "when my whole attention was called to a highly interesting, and to me a perfectly novel spectacle. Two large migrating bodies of Reindeer passed us at no great distance. They were descending the hills 
fiom the north-west, and crossing the plain on their way to the forests, where they spend the winter. Both bodies of deer extended further than the eye could reach, and formed a compact mass narrowing towards the front. They moved slowly and majestically along, their broad antlers resembling a moving wood of leafless trees. Each body was led by a deer of unusual size, which my guides assured me was always a female. One of the herds was stealthily followed by a Wolf, who was apparently watching for an opportunity of seizing any one of the younger and weaker deer which might fall behind the rest; but on seeing us he made off in another direction. The other column was followed at some distance by a large black Bear, who, however, appeared only intent on digging out a nouse's nest every now and thenso much so that he took no notice of us."

On the warrantable assumption that migrations of a similar character formerly took place in this country, the large assemblage of animal remains at the Reindeer-ford at Windsor is easily accounted for. In the gravels on which Oxford stands, says Professor Boyd Dawkins, the Reindeer is found in greatest abundance; at Bedford it is associated with flint implements, the Red-deer, and Hippopotamus; at Lawford, near Rugby, with the Cave Hyæna; at Fisherton, near Salisbury, with the Cave Lion, Urus, Roedeer, Marmot, and Lemming; in Kent also it is abundant in the brick earth of Sittingbourne and Maidstone; in Somerset in the gravels of the Avon near Bath. Altogether, it has been determined in 
ten out of eighteen river deposits which have furnished fossil mammals, while the Red-deer has been found only in nine.*

During the arctic severity of the post-glacial climate the remains of the Red-deer were rare, while those of the Reindeer were most abundant. During the pre-historic period the Red-deer gradually increased in numbers, while the Reindeer as gradually became extinct. In its rarity in the latter epoch we have proof of the great climatal change that had taken place in France and Britain.

Professor Owen, in his "British Fossil Mammals," has figured a skull with antlers of the Reindeer found in a peat-moss on Bilney Moor, near East Dereham, Norfolk, and he gives a figure also of a metatarsal bone of this animal from the fens of Cambridgeshire. During the excavation that was made for the reservoir of the southern outfall of the metropolitan sewage at Crossness Point, on the south side of the Thames, near Erith, a fine antler of the Reindeer was discovered at the bottom of a layer of peat varying from five to firteen feet in thickness, along with the remains of Beaver and a human skull. Another antler was found in a shell marl underlying the peat near Whittington Hall, Lancashire. Leigh, in his "Natural History of Cheshire" (Bk. III. p. 84), notices a horn of the Reindeer which was found under a Roman altar at Chester.

In Ireland, as we learn fiom a 'Report on Irish Fossil Mammals' by Dr. Leith Adams ("Proc. Roy.

* Boyd Dawkins, Popular Science Rerieur, January, I 868. 
Irish Acid.," I 877 , 2nd ser: vol. iii.*), rernains of the Reindeer have been found in shell-marl under the Bog of Ballyguiry, near Dungarvan, co. Waterford; in the mud of Lough Gur, co. Limerick; and in clay under peat at Ballybetagh, near Kiltiernan, co. Dublin, where in 1847 the skull, horns, and lower jaw of a Reindeer were discovered by Mr. Moss. But the most remarkable discovery of remains of this animal in Ireland was that made in $\mathrm{I} 86 \mathrm{I}$, when a very perfect skull, with the antlers still attached, was found on the edge of the Curragh Bog, near Ashbourne, co. Dublin. This was brought to the notice of the Royal Dublin Society by Dr. Carte in 1863 , and is regarded as the finest specimen of Reindeer which has yet been found in a fossil state. $f$

Dr. Carte has also noticed three antlers, found at Coonagh, on the south side of the Shannon, in co. Clare. A large number of remains, representing at least thirty-five individuals, were found in Shandon Cave, near Dungarvan, associated with the bones of other animals. $\ddagger$ These specimens have all been preserved, either in the museum of Trinity College, or in the Museum of Science and Art, Dublin; and a noteworthy character of the horns is the uniformity of the beam, which is slender and round, as in English specimens and in the existing Reindeer of

* See also a paper by the same author on "Recent and Extinct Irish Mammals," "Proc. Roy. Dub. Soc.," Narch, I878.

† Carte, "Journ. Geol. Soc. Dub.," vol. x., p. I03, pl. vii.; and Geol. Mrag., vol. iii., p. 546.

+ Carte, "Journ. Roy. Dub. Soc.," vol. ii. p. I2 ; and Leith Adams, "Trans. Roy. Irish Acad.," vol, xxvi., p. 2 I7. 
Norway, and unlike the flattened antlers of the Siberian stock.*

As regards its occurrence in Scotland, much valuable information has been brought together by Dr. John Alexander Smith, in a memoir published in the "Proceedings of the Society of Antiquaries of Scotland," and entitled "Notice of Remains of the Reindeer (Cervus tarandus), found in Ross-shire, Sutherland, and Caithness, with notes of its occurrence throughout Scotland.' $\uparrow$

In I 866 part of a horn (apparently the tine that springs from the back part of the middle of the beam) was found with a flint arrowhead, and bones of an ox-Bos longifrons-and dog, near two hut circles, in the course of draining the MLor-aich Mor, or Great Grazing, as the Gaelic words signify-a flat, sandy tract to the east of Tain, Ross-shire, bordered on the north by the Dornoch Firth. $f$

These bones, which lay beneath the moss on a natural shell bed at no distance below the surface (the drainage being only carried to the depth of four feet), were forwarded for examination to Prof. Owen, who had no hesitation in identifying the horn referred to as that of a Reindeer.

Several similar fragments were found on clearing: out the ruins of an ancient circular fort or "broch"

* Leith Adams, "Report on Irish Fossil Mammals," l.c. Comparative figures of the horns of Lapland and Siberian Reindeer" are given in Murray's "Geographical Distribution of Mammals," pp. I52, I 53. See also Sir Victor Brooke, "Proc. Zool. Soc." 1878, p. 927, tig. I9.

† "Proc. Soc. Antiq. Scotl.," vol. viii. pp. I86-223.

+ Rev. J. M. Joass, "Proc, Soc. Antiq. Scotl.," vol. vi. p. 386. 
at Kintradwell, near Brora, Sutherlandshire, together" with the remains of domesticated animals (as oxen and swine), an iron spear-head and dagger, and ten human skeletons.* These notices are regarded by Dr. Smith as the first which have recorded the discovery of Reindeer remains associater with human dwellings in the British Islands.

Pennant, in his "History of Quadrupeds" (vol. i. p. I00, I78I), has referred to some fossil horns of the Reindeer, which, on the authority of Dr. Ramsay, Professor of Natural History in Edinburgh, are stated to have been found in a marl pit five feet below the surface, near Craigton, Linlithgowshire. Dr. John Scouler, of Glasgow, also, has describerl some fragments of Reindeer horns from the alluvium of the Clyde. These were found in beds of finely laminated sand on the north bank of the river, below the junction of the Kelvin, where also was discovered the cranium of a large ox (Bos primigenius).

In the Hunterian Museum, Glasgow, amongst a collection of deer horns, is preserved a fragment of the left antler of a Reindeer, which was found in boulder clay at Raesgill, on the north side of the Clyde, in the neighbourhood of Carluke.

When the loch of Marlee, in the parish of Kinloch, Perthshire, had been partly drajned for the sake of the marl, some very interesting animal remains came to light, amongst others the skeleton of a Beaver, already referred to, and a pair of horns and some

* Sce "Proc. Soc. Antiq. Scotl.," rol.v. p. 242. 
leg bones of the Reindeer.* These are probably the bones referred to in the old Statistical Account of Scotland (vol. xvii. p. 478), as having been found in Mr. Farquharson's marl-pit at Marlee, and surmised to be those of the Elk.

Dr. Smith has figured the smooth beam of a right horn of a young or female Reindeer (tom. cit., p. 23), taken from a cutting of the Forth and Clyde Junction Railway, in the basin of the Endrick, near Croftamie, Dumbartonshire. This specimen, which was identified by Professor Owen, was not in the boulder clay, but in a bed of blue clay, about seven feet thick, below it, between the boulder clay and the underlying rock of the district.

Again, on the farm of Greenhill, near Kilmaurs, Ayrshire, some antlers of a large Reindeer were found thirty-six feet below the surface, together with a tusk of the Mammoth. +

The late Sir William Jardine had, a few years since, an opportunity of examining some very interesting animal remains, which were exhumed at Shaws, about four miles from his residence in Dumfriesshire. Besides several bones of the Red deer, Roedeer, Bos primigenius (the last named rare), and a very perfect skull of the Brown Bear, already referred to, was a portion of an antler; which, from its outline, flattened character, and smooth surface, could have belonged only to a Reindeer; it measured about twelve

* Neill, "Mcm. Wern. Nat. Hist. Soc.," vol. iii. p. 2I4.

† See Geikie, "Mcmoir on the Phenomena of the Glacial Drift of Scotland,' "Trans. Geol. Soc. Glasgow," vol. i. p. 7r (1863). 
inches long by four and a half inches in its greatest breadth.

In 1865 Sir Philip Egerton met with a sinall fragment of antler in a peat hag in Ross-shire, which, according to Professor Boyd Dawkins, "beyond all doubt belonged to this animal."

The last instance which we shall notice of the discovery of Reindeer remains in Scotland has reference to the county of Caithness; and we take this last because it leads directly to a consideration of the historical evidence which is to be found concerning the former existence of this animal in Scotland, and which evidence relates exclusively to this country.

Dr. Smith, in the memoir referred to, has described at some length the ancient circular forts or "brochs" which are to be met with in some parts of Scotland, and which in several instances have yielded such very interesting relics of pre-historic man. Amongst these is the "broch" of Yarhouse, in Caithness, about five miles to the south of Wick, on the estate of Thrumster, and at the south end of the Loch of Yarhouse. Of this Dr. Smith has given a very full description, fram notes by $\mathrm{Mr}$. Anderson and Mr. Robert Shearer, of Thrumster, who carefully examined it, and his remarks are illustrated by a ground plan, which renders his account the more instructive. When the examination of this "broch" first commenced, it was to all appearance nothing but a grass-covered mound, and was situated on what had once been an island, a fosse about twenty feet broad having separated it from the land. It 
would be beside our present purpose to refer in detail to the many interesting objects which were brought to light on opening up this mound. Suffice it to say that (in addition to human remains, bones of domesticated animals, shells of periwinkle, limpet, and cockle, coarse hand-made pottery and rude stone implements) the smooth flattened horns of the Rein. deer came to light, showing that this animal was either domesticated by the dwellers in the "broch," or at all events was hunted by them, and used for food.

Under very similar conditions, other remains of the Reindeer have been exhumed from the Har-

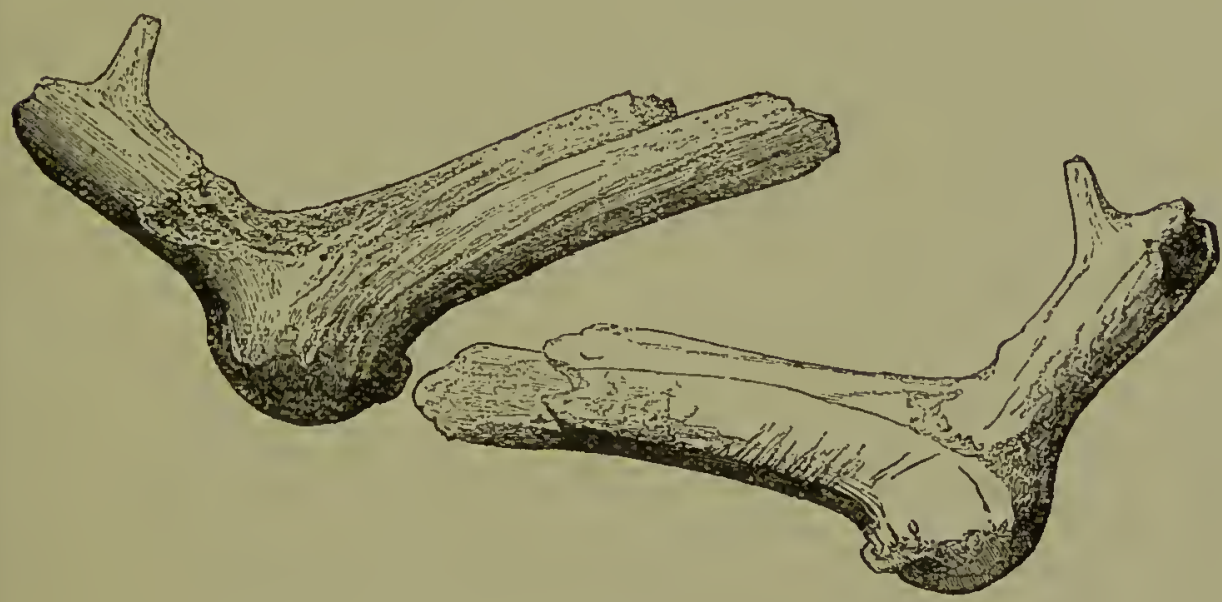

FRAGMENTS OF REINDEER HORN, CAITHNESS.**

bour Mound at Keiss Castle, also in Caithness, a full account of which may. be found in Laing's "Pre-historic Remains of Caithness," and a briefer notice in Dr. Smith's paper above referred to. Now, this discovery of the remains of Reindeer asso-

* Copied from the Memoir referred to, by permission of Dr. J. A. Smith and the Society of Antiquaries of Scotland. 
ciated with man in Caithness is of especial interest, as tending to confirm the truth of the tradition that the jarls of Orkney in the twelfth century were in the habit of crossing the Pentland Firth for the purpose of hunting the Red-deer and the Reindeer in the wilds of Caithness.

Torfreus, in his history of Orkney ("Orcades, seu Rerum Orcadensium Historia," Lib. I. cap. xxxvi.), written at the close of the seventeenth century, thus translates a passage from the "Orkneyinga Saga:" "Consueverant Comites in Catenesiam, indeque ad montana ad venatum caprearum rangiferorumque quotannis profiscisi." Dr. Fleming, in his "History of British Animals," published in Edinburgh in I 828, quoting this passage, remarks that "it would lead to the belief that Reindeer once dwelt in the mountains of Caithness, were it not extremely probable that Red-deer were intended." Dr. Hibbert also, who has written an elaborate critique upon the subject, ${ }^{*}$ was at first inclined to think that Torfous had inade a mistake here, and that he should have stated "the Roe-deer and the Red-deer," instead of "the Roe and the Reindeer." But a learned Icelander, Jonas Jonæus, who in r 780 published an abstract and Latin translation of the $S a g a,+$ has explained the manuscript sources

* ' On the Question of the Existence of the Reindeer during the 'Twelfth Century in Caithness,' in Brewster's Edinb. Journ. of Science, New Series, vol. v. p. 50.

$\dagger$ "Orkneyinga Saga sive Historia Orcadensium : Saga hins Helga Magnusa Eyia Jarls, sive Vita Sancti Magni Insularum Comitis Islandice et Latine," edidit J. Jonæus, 4to, Hafniæ, I78o, p. 384 . 
from which Torfreus derived his account, and has shown that the animals hunted by the jarls of Orkney were in reality not the Roe, but the Reddeer, and the Reindeer, living at the same time in that part of Scotland. The original passage runs thus: "Thar var sithr Jarla naer hvert sumar at fara yfer à Katanes oc thar upp à merkr at veida Rauddyri edr Hreina;" which is translated by Jonæus as follows: "Solebant Comites quavis fere cestate in Tiatenesum transire, ibique in desertis feras rubras et rangiferos venari"-the jarls of Orkney were in the habit of crossing over to Caithness almost every summer, and there hunting in the wilds the Reddeer and the Reindeer."

Dr. Hibbert accepts this version of Jonæus, and so also does Professor Brandt of St. Petersburgh. In the English edition of Jon, A. Hjaltalin and G. Goudie (Edinb., I873, p. I82), the words are translated: "Every summer the Earls were wont to go over to Caithness and up into the forests to hunt the Red-deer or the Reindeer." An eminent Icelandic scholar, however, Mr. Eirikr. Magnusson of Cambridge, is of opinion that neither version is quite correct as regards the latter words, the literal translation being: "It was the custom for the Earls nearly every summer to go over into Caithness and then up into the woods to hunt Red-deer or reins."

Mr. Magnusson further observes that the word edr has two meanings, equivalent to the Latin sive and vel, and he therefore considers it uncertain whether the proper reading is that they went to 
hunt cither Red-deer or Reindeer, or whether, as appear's to him more likely, the Saga inan was under the impression that rauddyr and hrein were synonymous terms. *

The author of the Saya, says Professor Boyd Dawkins, must have been well acquainted with the animal in Norway, Sweden, and Iceland, and there seems nothing improbable in the natural inference that the animal they called reindeer undoubtedly was one. The inclement hills of Caithness lie in the same parallel of latitude as the south of Norway and Sweden, in which the animal was living at the time; and its food, the brushwood, and especially the reindeer moss (Cladonia rangiferina) is still found extensively over Scotland. Indeed, the abundance and variety of lichens is specially noted as a peculiarity in the Statistical Account of the parish of Wick, where the reindeer moss is stated to grow to the height of three or four inches among the heather.

The jarls of Orkney referred to (Rögnvald and Harald), according to Jonreus, hunted in Caithness in II 59.

There is another point worth notice, as remarked by Professor Boyd Dawkins. ‘ "The Reindeer is mentioned in the Orkneyinga Saga along with the Reddeer. At the present day these animals occupy different zoological provinces; so that the fact of their association in Caithness would show that in the twelfth century the Red-deer had already appropriated

* Alston, "Fauna of Scotland" (Mammalia), p. 36 (19So).

† Popular Science Revien, 1S68, p. 43. 
ever, it may be urged that the fact of the hom having been found "deep down below the surface" seems opposed to the theory of recent origin.

Several attempts have been made fiom time to time to reintroduce the Reindeer in Great Britain, but without much success. Sir Henry Liddell, who made a tour through Sweden and Lapland, brought five Reindeer to his estate in Northumberland, where they bred, and for some time seemed likely to thrive; but they did not live long: * Fleming refers to an experiment of the kind made by the Duke of Athole ("Hist. British Animals," p. 27), and Scrope says the Earl of Fife introduced some into the great forest of Marr in Aberdeenshire ("Days of Deerstalking," p. 406). But they all died, notwithstanding their being turned out on the summits of the hills, which are covered with dry moss, and on which it was supposed they would be able to subsist. Some year's previously to this, a similar experiment had been tried in Orkney, where Mr. Robert Traill, in is 8 6, turned out three Reindeer, a male and two females, which he had imported from Archangel. But they soon died, towards the end of winter-from want, it was believed, of their proper food, in addition to the supposed unsuitability of the climate. It is stated by Messis. Baikie and Heddlet that "not being found to answer the purposes intended, they were allowed to die out."

* Consett's "Tour through Swelen," p. I 52.

+ "Hist. Nat. Orcadensis," p. 19. 


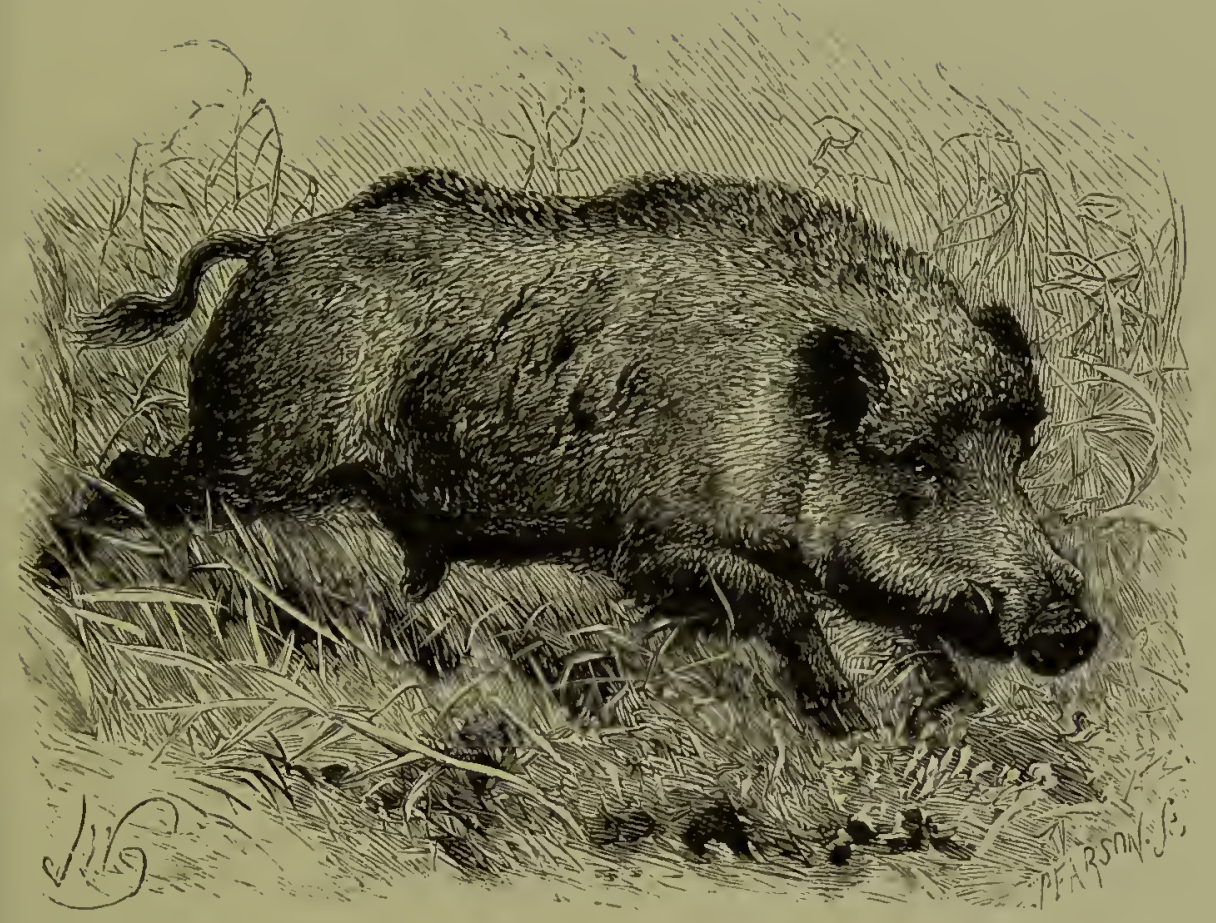

\section{THE WILU BOAR.}

Sus scrofu.

The Wild Boar is one of the oldest forest animals in Britain, and one of which we find the earliest mention in history. Characteristic figures of it appear on ancient British coins, * and it is one of the earliest animals figured in Celtic works of art. $\dagger$ Britons, Romans, Saxons, and Normans all hunted it

* Evans's "British Coins," pls. vi., viii., xi., xii., aud xiii.

† "Horæ Ferales," p. I85, pl. xiv.; Montcllier, "Mémoires sur los Bronzes Antiques," Paris, I865; aud Stephens' "Literature of the Kymry," p. 250. 
here in turns. Figures of the wild boar are found on Roman monuments in England; Pennant has noticed one such at Ribchester, formerly a famous Roman station. "It is supposed," he says, "to have been an honorary inscription to Severus and Caracalla, by the repetition of the address. It was done by a vexillatio of one of the legions quartered here. A stone fixed in the wall of a small house near the church gives room to suppose that it belonged to the twentieth. The inscription is LEG. XX. W. FEC, and on one side is the sculpture of a Boar, an animal I have in two other instances observed attendant on the inscriptions made by the famous Legio vicessima valens victrix." **

Nor should we omit to notice the Roman altar which was found in 1749 near Stanhope, in the bishopric of Durham, usually referred to as the Weardale altar, and dedicated by a grateful Roman prefect to the god Sylvanus for the capture of an enormous Boar, which many of his predecessors had in vain attempted to destroy. On this altar was discovered the following inscription:- "Sylvano invicto sacrum . . . . ob Aprum eximice formce captum, quem multi antecessores ejus prodari non potuerunt." A similar altar, also dedicated to Sylvanus by the hunters of Banna, was found at Birdoswald, in Northumberland.†

* "Tour to Alston Moor," 180 , p. 93. See also Horsley, "Britannia Romana, or the Roman Antiquities of Britain," folio, 1732. f Wright, "The Celt, the Roman, and the Saxon," pp. 207, 267. 
Aubrey has given a minute account of a sculptured representation of hunting the wild boar, over a Norman doorway at Little Langford Church. This bas-relief is figured in Hoare's "Modern Wiltshire."

After the expulsion of the Danes, and during the short restoration of the Saxon monarchy, the sports of. the field still maintained their ground, and hunting: and hawking were favourite pastimes. A painting on a MS. of the ninth century, in the Cotton Library,

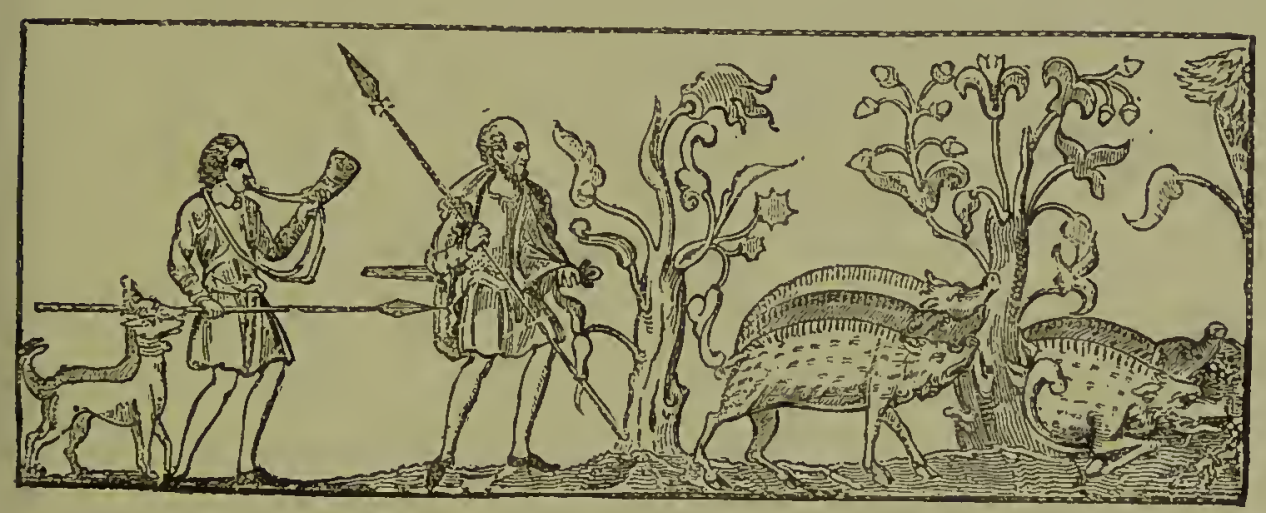

WILD BOAR MUNTING. FROM A ML. OF THE NINTH CENTURY.

represents a Saxon chieftain, attended by his huntsman and a couple of hounds, pursuing wild boars through a wood."*

In the "Colloquy of Alfric," a hunter of one of the royal forests gives a curious account of his profession. When asked how he practises his craft, he replies: "I braid nets and set them in a convenient place, and set on my hounds, that they may pursue the beasts of chase, until they come unexpectedly to the nets, and so become entangled in them, and I slay them in the nets." He is then asked if he cannot hunt without * Strutt's "Sports and Pastimes," p. 5, fig. I. 
nets, to which he replies: "Yes, I pursue the wild animals with swift hounds." He next enumerates. the different kinds of game which the Saxon hunter: usually hunted- "I take harts, and boars, and deer; and roes, and sometimes hares." "Yesterday," he continues, "I took two harts and a boar .... the harts with nets, and I slew the boar with my weapon." "How were you so hardy as to slay a boar?" "My hounds drove him to me, and I, there facing hirn, suddenly struck him down." "You were very bold, then." "A hunter must not be timid, for various wild beasts dwell in the woods."

The Welsh laws of Howel Dha (A.D. 940, fide Spelman and Llwyd,) provided (cap. xvi. § ro) that the wild boar should be hunted between the ninth of November and the first of December, but later on, in Edward II.'s time the season for hunting the boar was between Christmas Day and Candlemas Day (Feb. 2).

Edward the Confessor, whose disposition seems to have been suited rather to the cloister than to the throne, would join in no secular amusement but the chase. According to William of Malmesbury,* he took the greatest delight to follow a pack of swift hounds in pursuit of game, and to cheer them with his voice. He had a royal palace at Brill, or Brehull, Bucks, to which he often repaired for the pleasure of hunting in his forest of Bernwood. This forest, it is said, was much infested by a wild boar, which was

* "Hist. Reg. Anglorum," Jib. II., cap. xiii. 
at last slain by one Nigell, a liuntsman, who presented the boar's liead to the king; and for a reward the king gave him one hide of arable land, called Derehyde, and a wood called Hulewood, with the custody of the forest of Bernwood, to hold to him and his heirs by a horn, which is the charter of the aforesaid forest. Upon this land Nigell built a lodge. or mansion-house, called Borestall, in memory of the slain boar. For proof of this, in a large folio vellum book, containing transcripts of charters and evidences relating to this estate (supposed to have been written in or before the reign of Henry VI.), is a rude delineation of the site of Borestall House and manor, and under it the figure of a man presenting on his knees to the king the head of a boar on the point of a sword, and the king returning to him a coat of arms, argent, a fesse, gules, between two crescents, and a horn, vert.

The same figure of a boar's head was carved on the head of an old bedstead, now remaining in the tower or lodge of that ancient house or castle, and the arms are now to be seen in the windows, and in other parts. And, what is of greatest authority, the original horn, tipped at each end with silver gilt, fitted with wreaths of leather to hangु about the neck, with an old brass seal ring, a plate of brass with the sculpture of a horn, and several lesser plates of silver gilt, with fleur-de-lys, has been all along preserved by the lords of Borestall, under the name of "Nigell's horn," and was in the year 1773 in the possession of John Aubrey, Esq. (son and heir of Sir Thomas 
Aubrey, Bart.), to whom this estate descended without alienation or forfeiture, from before the Conquest, by several heirs female from the fimily of Nigell to that of Aubrey.**

At the Conquest, Inglewood Forest was held by the Scots, from whom it was taken by the Conqueror, and given to Ranulph de Meschines, who made a survey of the whole country, and gave his followers all the frontiers bordering on Scotland and Northumberland, retaining to himself the central part between the east and west mountains, described as "a goodly great forest full of woods, ren-deer and fallow, wild boars, and all manmer of wild beasts." $\dagger$

A forest law of William I. ordained (A.b. IO87) that any one found guilty of killing a stag, roebuck, or wild boar should be deprived of his eyes.

Henry I. was especially fond of boar-hunting, as we learn from Holinshed, who stigmatizes it as "a verie dangerous exercise;" and Edward I. made several gronts of land, which were held by the serjeanty of keeping or providing boarhounds.

Robert de Avenel, who lived A.D. I I53-I I65, in granting the right of pasturage in Eskdale to the monks of Melrose, reserved to himself the right to pursue the wild boar, deer, and stag.t.

A curious story referring to a wild boar hunt at

* "Archæologia," vol. iii. pp. 3, I 5 ; Kenmett's "Paroch. Antiq.," and Blount's "Ancient Tenures," p. 243 (ed. I S I 5).

+ Longstaffe, "Durham before-the Conquest."

+ Morton, "Monastic Anuals of Teviotdale," pp. 273, 274. 
this very period, in Eskdale, is related by Blount in his "Ancient Tenures" (p. 557, ed. I 8 I 5). He says that in the fifth year of Henry II. the lord of Uglebarnby, William de Bruce, the lord of Snaynton, Ralph de Percy, and a gentleman freeholder named Allotson, met on the I 6 th October to hunt the Wild Boar in a certain wood called 'Eskdale-side,' belonging to the Abbot of the monastery of Whitby, by name Sedman.

"Then the aforesaid gentiemen did meet with their hounds and boar-staves in the place aforesaid, and there found a great wild boar; and the hounds did run him very hard near the chapel and hermitage of Eskdale-side, where there was a monk of Whitby who was a hermit. The boar, being so hard pursued, took in at the chapel door, and there laid him down and died immediately. The hermit shut the hounds out of the chapel, and kept himself at his meditation and prayers, the hounds standing at bay without. The gentlemen in the thick of the wood, following the cry of the hounds, came to the hermitage, and found the hounds round the chapel. Then came the gentlemen to the door of the chapel, and called on the hermit, who did open the door, and then they got forth, and within lay the boar dead, at which the gentlemen, in a fury because their hounds were put out of their game, ran at the hermit with their boarstaves, whereof he (subsequently) died. Then the gentlemen, knowing and perceiving that he was in peril of death, took sanctuary at Scarborough; but at that time the Abbot, being in great favour with 
the King, did remove them out of the sanctuary, whereby they came in danger of the law, and not privileged, but like to liave the severity of the law, which was death." But the hermit, being a holy man and at the point of death, interceded for them. On the roth December he sent for them and for the Abbot, and in the presence of the latter forgave them freely, begged that they might not suffer the penalty which they had incurred, but perform, instead, a penance (fully described by Blount) which he then and there enjoined them; and having uttered it prayer, he sank back and died?

Fitz Stephen, who wrote his description of London in II74 (see Introduction, p. 5), says that the forest by which London was then surrounded was frequented by Boars as well as various other wild animals.

Edward III. hunted the Wild Boar in Oxfordshire, as we may infer from the following translation of a record of the tenure of land in that county by the service of finding the king in "boar-spears" whenever he came to hunt there:-

"Anno I339, 13th and I4th Edward III., an inquisition was taken on the death of Joan, widow of Thomas de Musgrave of Blechesdon, wherein it appears that the said Joan held the moiety of one messuage, and one carucate of land in Blechesdon of the King; by the service of carrying one boar-spear (unam hastam porci), price twopence, to the King, whenever he should hunt in the park of Cornbury; and do the same as often as the King 
should so hunt, during his stay at his manor of Wodestock." "**

A quaint illustration of the mode of attacking a Boar, copied from MS. of the fourteenth century, which is preserved in the Douce collection, is given by Strutt in his "Sports and Pastimes," and is here reproduced.

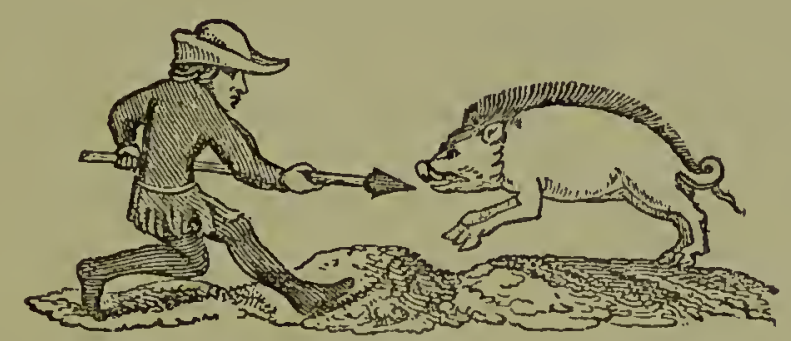

SPLARISG A BOAR. FROM A MS. OF THE FOURTEENTII CENTURL:

The Boar was a badge of Edward III., and might therefore have been borne by any of his descendants; but Richard III. is the only one to whom its adoption has been traced. $\dagger$

In the Privy Purse Expenses of Elizabeth of York, eldest daughter of Edward IV. and consort of Henry VII., is the following entry under date $23 \mathrm{rd}$ Nor. 1502 :-

Itm. the same day to a servaunt of Sr. Gilbertes Talbottes in rewarde for bringing a wylde bore to the Quene . . . . . $x s$.

And in the "Household Book" kept by the steward of Squire Kitson of Hengrave, county Suffolk,

* Kennet, "Parochial Antiquities," p.45o. By some unaccountable mistake Kennct translates unam hastam porci "one shield of brawn," and his view is adopted by Blount, "Ancient Temmres," p. 97.

The use of "Bore-speres" in Norfolk, A.D. 1450-54, is referred to in the "Paston Letters," ed. Gairdner, vol. i. pp. I07, 27 I.

† "Archeologia," vol. v. p. 17; Hawkins, "English Coins," p. 278. 
beginning 1st October, I572, we find under date January, I 573 , this item:-

"'To Miles Mosse for" a bore which he is charged to deliver every Christemas as rent rated to the value of $\mathrm{r} s$, for which he paid xxs, and so there was allowed of that vs."

To judge by the remains of the animal which have been found in various parts of the British Islands, Wild Boars at one time must have completely overI'un the country. They were hunted in all the great forests, and in ancient surveys they are often men-

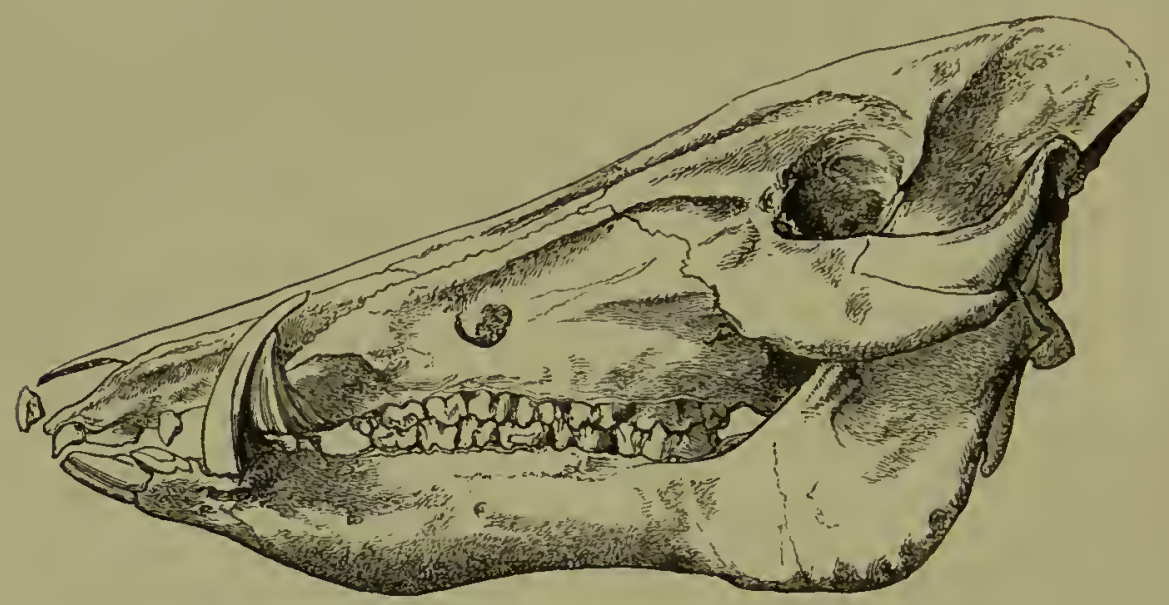

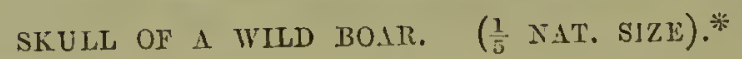

tioned amongst the wild animals of the district surveyed.

Thus Erdeswick, who began his survey of Staffordshire about I593, speaking of Chartley, says, "The park is very large, and hath therein red deer, fallow deer, wild beasts (i.e., wild cattle), and swine." In the peat mosses of Northumberland and Westmoreland, skulls and bones of the Wild Boar have

* From a specimen in the Museum of the Royal College of Surgcons. 
been frequently exhumed, ${ }^{*}$ as well as in the peat at Newbury, Berks, and Romsey, Hants. ${ }^{\dagger}$

Leland tells us that at Blakeley, Lancashire, "wild bores, bulls, and falcons bredde in times paste," and there is close to Blakeley a place still called "Boar's Green." Leland also speaks of "Wild Bores or Swyne" on one of the Scilly Islands (Itin. second ed. vii. I08); but the animals referred to were probably domestic swine which had been introduced there, and had run wild. At Great Grimsby an annial quit rent of $£ \mathrm{I} 3 s .4 d$. is still paid to the Corporation of Grimsby in respect of a wood where formerly it possessed the right of hunting the Wild Boar, a payment presumed to be an acquittal from the burden of having to provide one of these animals for the corporation to hunt. "The seal of the mayor of "Great Grimsby bears the legend. Sigillum majoritatis de Grimesby, and contains a representation of a Boar closely pursued by a dog, behind which is a huntsman winding his horn. This device is descriptive of a privilege enjoyed by the mayor and burgesses of Grimsby, of hunting in the woods of the adjacent manor of Bradley, the lord of which was by his tenure obliged to provide yearly a Wild Boar for their diversion. These seals have long been laid aside and others adopted, containing the arms of the corporation:-azure, a chevron, sable, between three boars' heads; the shield surrounded by a festooned

* Some remarkably fine tusks of the Boar, found in Cresswell Moss, are preserved at Middleton Hall, near Wooler, the seat of Mr. G. H. Hughes.

† Collet, "Phil. Trans." 1757, p. 112. 
border, gules, with a narrow edge, vert. Above are two oak-branches crossed, proper, embowering an escallop shell, azure." "*

In the Museum of the Royal College of Surgeons are preserved two of the inferior incisors, and the right and left lower canines of a Wild Boar which, with a quantity of hazel nuts, were transmitted to John Hunter in May, I787, by Mr. Jones, of Abingdon, accompanied by a letter in the following terms :-

"The inner jaw of a Wild Boar or some other animal, and the nuts which I have taken the liberty to enclose in the box, were a few days since found about ten feet under ground by a labourer as he was digging peat or turf. Several single tusks have been found, and they were all worn in the manner you will observe these to be at the extremities; and the quantity of nuts was very considerable: they seemed to lay in a layer of white sand between the strata of peat. From whence could they come? Is it possible they could remain there ever since the deluge?

$$
\text { (Signed) W. Joxes. }
$$

"Abingdon, Berks, MFay 23rd, 1787."

"The layer of sand and nuts extended upwards of eighteen feet horizontally."

In the same Museum, specimen No. 1079, is the left inferior tusk of a Wild Boar (Sus scrofa)

* Allen, "Hist. Co. Lincoln" ( 1830$)$, rol. ii. p. 24 I. 
exhumed, eight or ten feet from the surface, out of the peat meadows, half a mile west of Newbury in Berkshire, presented by Mr. Alexander, surgeon, Newbury.

A good account of this locality, under the name of the "Peatpit near Newbury," is contained in a letter dated February 24, 1757, from Dr. John Collet to the Bishop of Ossory, which is printed in the "Philosophical Transactions" for 1757 (p. rog).

Many localities seem to indicate by their name the former haunts of this once common animal. Brancepeth Castle, Durham, appears to have derived its name (Bran's path), from a noted Boar whiclı infested that neighbourhood. Swindon, Swinford, Swinfield, and Strindale;" "Wild Boar Fell" in Westmoreland, particularly described by Pennant, $\dagger$ and "Wild Boar Clough" in Cheshire, are all names suggestive of the ancient haunts of this animal. So also are Hogmer (Hants), Eversham and Everley, (from eofor, a boar), Boarhunt (Hants), and Boarsford (Hereford).

Prior to the introduction of Christianity into Scotland, the country by which St. Andrews is surrounded wore the aspect of a forest, in which a few patches of cultivated ground seem to have been interspersed. In this forest the hog or swine in its wild state abounded; and from this circumstance it was denominated by the Picts, who at that period

* Some interesting notes on the names of plaees eommencing with "Swin" will be found in The Antiquary, vol. i. pp. 47, 94, 139, 234, and vol. ii. p. 84 .

† "I'vur to Alston Moor," p. 134 . 
occupied the east coast of Scotland, Mucros-muc in their language, which was the Celtic or Gaelic, signifying a sow or boar, and ros a peninsula or promontory. 'The correctness of this derivation is said to be confirmed by the fact that near the extremity of the parish the village of Boarhills still retains the original name of the district, but translated into the modern language. Boethius, however, states (fol. 272) that the land in question was given to the See of St. Andrews by Alexander the First about I I 24, and was named "the Boar's chase" (cursus apri) in consequence of an enormous Boar, which had done great damage in the neighbourhood, having been pursued and eventually killed there.* $\mathrm{He}$ further adds that its huge tusks, measuring twelve inches long, and three in their greatest width, were preserved as trophies, and chained to the high altar of St. Andrews. ${ }^{\prime}$ His words are :- "Auxit [Alexander] quoque facultates sacro cedis D. Andrece, cum aliis quibusdam proediis, tum eo agro cui nomen est 'Apri' cursus,' ab apro immensi magnitudinis, qui edita hominum et pecorum ingenti strage, sape nequicquam a venatoribus, magno ipsorum periculo, petitus, tanden. ab armata multitudine invasus, per hunc agrum profugiens confossus est." He adds:- "Eatant immanis hujus bellua indicia, dentes, quos maxillis exsertos. habcnt, admiranda magnitudinis longitudinis enim

* See also Spotswood, "Hist. Church of Scotland" (1665), p. 134; and Martine, "Reliquico Divi Andrea" (1797), p. 94.

† "New Statist. Acct. Scotland," vol. ix.p. 449. The arms of the. city of St. Andrews represent a boar leaning against a tree. 
sunt 16 diyitorum et latitudinis 4, relegati catenulis ad cellas Divi Andrex."*

Reference to a Boar-hunt in Scotland at an earlier date than this, however, is to be found in a Latin MS. history of the Gordon family, dated I 545, compiled In Irom older MSS. by John Ferrarius, of Piedmont, a monk in the Abbey of Kinloss, Morayshire, who also wrote a Supplement to the work of Boethius. A copy of the MS. referred to made for Sir Robert Gordon in 16r $3_{3}$ and entitled "Historice compendium de origine et encremento Gordonice familice in Scotia, apud Kinloss, anno I 545," is preserved in the Advocates' Library, Edinburgh, and from this we learn that amongst those who assisted Malcom III. of Scotland against the English about the year I057 was one Gordon, who some time previously had slain a fierce Boar which had committed great depredations in the neighbourhood of the Forest of Huntly. For this act of prowess he was rewarded by the King, who bestowed upon him the lands of Gordon and Huntly, and sanctioned his carrying on his banner three boars' heads, or, in a field, azure. In the English translation of this rork, from which Pennant quoted (vide antea, p. I9), the animal slain by Gordon is called a Bear, but this, as we have already shown (p. 24), was the Scottish pronunciation of Boar, and reference to the Latin original shows that the animal in question was unmistakably a Boar,

* This must have been a splendid pair of tusks. The Roman digit, it should be remembered, was the sixteenth part of a foot; and these tusks were doubtless measured along the outside curve. 
immanem aprum, and that the heads upon the banner were likewise boars' heads-tria aprorum capita aurea.

In the Highlands, the existence of the Wild Boar is generally and familiarly reinembered. Its namesFiadh-Chuliach (generically the wild hog), Fiadh-Thorc (the Sanglier or Wild-Boar), Fiadh Mhuc (the Wild Sow)-are still well known, and traces of its times and locality are retained in tradition, ancient poetry, and the names of many places denominated from its haunts, as Slochd-Tuirc, the boar's den, Druim-anTuirc, the boar's ridge, and Beannan Tuirc, the boar's mountain.**

On the west side of Benin-glo, Perthshire, are two places called "Carn-torey" and "Coire-torey"-i.c., the hill and the hollow of Boars ; in the same county is the Boar's Loch (Loch-an-tuirc).t Traces of this animal have been found in Gordon parish, Berwickshire, where land is said to have been granted by William the Conqueror to one who killed a certain Wild Boar which infested the district.t.

In Ireland swine existed, both in a wild and domesticated state, from the very earliest times, and have ever since contributed largely to the wealth of the people. The Wild Boar (Torc fiadhain) abounded in the woods, which formerly covered a large portion of the country, and fed upon the acorns and beech-

* Stuart, "Lays of the Deer Forest," ii. p. 217.

† "Old Statist. Acct. Scotland," rol. ii. p. 478.

\& Ilid., vol. riii. p. 53 . 
mast; hence the frequent mention in the ancient annals of Ireland, of the failure of these crops, as well as the years in which they abounded.*

The earliest account known of the wild animals of Ireland is to be found in a tract De miralilibus Sacree Scripture, written by an Irish ecclesiastic named Augustine about the middle of the 7 th century, and amongst other ferce naturce, Wild Boars (sylvaticos porcos) are especially mentioned. $\uparrow$

Among the restrictions put upon one of the kings of Ulster in the Lealhar na g-Ceart, or "Book of the Rights and Privileges of the King's of Erin," was that he was not to go into the Wild Boar's hunt, or to be seen to attack it alone. Giraldus Cambrensis, in his Topographia Hibernice, says, "In no part of the world have I seen such an abundance of boars and forest hogs. They are, however, small, misshapen, wary, no less degenerated by their ferocity and venomousness than by the formation of their bodies."

As regards their size, the statement of Giraldus has been confirmed by palæontologists. Compared with veritable specimens of the ancient Wild Boar of Northern Europe, as found in the peat mosses of Scandinavia, especially in Zeeland, the Irish Wild Boar appears to have been a very diminutive animal. (Wilde, l. c.) Dr. Scouler asserts that they continued

*Wilde, "Proc. Roy. Irish Aead.," vol. vii. p. 208.

+ 'The brief allusion made in this tract to the fauna of Ireland, as quoted by Reeves ("Proc. Roy. Irish Acad." 1861) is as follows:"Quis cnim, verbi gratia, lupos, corvos, et sylvaticos porcos et vulpes, taxones et 7epusculos ct sesquivolos in Hibcrniam deveneret." This is one of the very few sources of information quoted in this volume which we have been nnable to examine and verify. 
to be plentiful in Ireland down to the seventeenth century, but the exact date of their extinction he was unable to ascertain.*

Many places in Ireland are called after the Wild Boar, as Sliabh-na-muice in Tipperary; Gleann-namuice-duibhe near Newry; Ceann-tuirc in the Co. Cork. Muckross and Torc, also, at Killarney, are derived from the same root. The word Muckalagh enters largely into Irish topographical names, and signifies a place where pigs feed-probably on acorns. (Wilde, l.c.)

Tusks of Wild Boars, dug up in Ireland, according to Thompson, are often of goodly dimensions. ${ }^{\dagger}$

Several attempts have been made to reintroduce these animals for the purpose of hunting, but, from various causes, none of the experiments proved very successful. In some instances they throve weil and increased, but the opposition of those whose crops they damaged was fatal to their existence for any length of time. Charles I. imported some from France, f and turned them out in the New Forest, where, according to Aubrey, "they much encreased, and became terrible to the travellers." However, " in the civill warres," he says, "they were destroyed,

* "Journ. Gevl. Soc. Dublin," vol. i. p. 226. See also Wilde, "Proc. Roy. Irish Aicad.," vol. vii. p. 208.

† " Nat. Hist. Ireland," vol. iv. p. $3^{6 .}$

+ Gilpin says "from Germany." He confirms Aubrey's statement as to their increase in the New Forest, and adds that "there is found there at this day (I79I) a breed of hogs, commonly called forest pigs, which are very different from the usual Hampshire breed. and have about them several of the characteristic marks of the Wild Boar."Furest Scenery, vol. ii. pp. 168-169 (ed. Lauder). 
but they have tainted all the breed of the pigges of the neighbouring partes, which are of their colour; a kind of soot colour." "* This was written in 1689 . Evelyn, in a note to this passage, observes: "There were Wild Buars in a forest in Essex formerly. I sent a Portugal boar and sow to Wotton in Surrey, which greatly increased; but they digged the earth so up, and did such spoyle, that the country would not endure it: but they made incomparable bacon."

At a later period, as recorded by Gilbert White, General Howe turned out some German Wild Boars in the forests of Wolmer and Alice Holt, of which he had a grant from the Crown; but, as White says, "the country rose upon them and destroyed them."

The late Earl of Fife, who tried many experiments in introducing different animals into the Forest of Marr, turned out some Wild Boars by the advice of the Margrave of Anspach, who was at Marr Lodge on a visit; but the experiment in this case did not answer, for want of acorns, their principal food. $f$

Forty years ago, Mr. Drax, of Charborough Park, Dorsetshire, made a similar experiment. Two pairs, one from Russia the other from France, were originally turned out in the woods at Charboro', and after remaining there several years they, or their descendants,

* Aubrey, "Nat. Hist. Wilts," p. 59.

+ "Nat. Hist. of Selborne," Letter ix. to Pennant.

‡ Scrope's "Art of Deer Stalling," p. 406. 
were removed to Morden, a few iniles distant. The Russian breed was wilder and more ferocious than the French. The Iitters, which averaged from Io to 12 , were not interfered with, but ran wild with their parents. They were not hunted but caught in nets or shot. Writing to a mutual friend in September, I879, Mr. Drax says: "I fenced them in with a wood paling in the wood where I built the present tower, and used to shoot them. The latter part of the time I kept them at Morden Park, and bred a lot of them, feeding them on turnips and corn. They were savage and troublesome, however, to keep within bounds, and I therefore killed them. They were good eating when fed upon corn."

Scott, in his "British Field Sports," the second edition of which was published in I 820 , says, "Several Wild Boars of this accidental kind have flourished within my memory; in particular two in the woods between Mersey Island and Colchester, in Essex, which many years since were the terror of that neighbourhood for a considerable time, and stood many a gallant hunt."

In olden times the enclosure in which the Boars used to be fattened was termed a "Boar-frank." Shakespeare uses the word in the Second Part of Henry IV." :

"Doth the old boar feed in the old frank :"

And in one of the Household Books of Lurd William Howard, of Naworth Castle, Cumberland, under date Sept. 25, 1622, is an entry of payment

"To Rob. Burthom for mending a boar-frank ... . iiijd." 
These "boar-franks," it would seem, were at one time not uncommon in parts of Suffolk. The amonymous author of the "History and Antiquities of the Ancient Villa of Wheatfield in the County of Suffolk" (first printed in 4to in I758, and republished in the second volume of Dodsley's "Fugitive Pieces," pp. 77-1 15), referring to the state of the parish and the manners and pursuits of the inhabitants, remarks :- " The prevailing taste r'uns much upon building temples to Cloacina and menageries for Wild Boars; structures in themselves beautiful, but at the expense of that noble Roman Way, the Vic Icenorum, that leads through the parish, which they narrow and obumbrate."

At Chartley Park, Staffordshire - where, three hundred years ago, ás we learn from Erdeswick, wild swine roamed at large-the present Earl Ferrers proposed to reintroduce these animals, having been presented, with a boar by Mr. W. J. Evelyn, of Wotton House, near Dorking, and with a sow by Mr. F.H. Salvin, of Whitmoor House, near Guild ford. The proposed experiment, however, failed, for the boar died on the road, from the heat of the weather, and the sow not long afterwards, from an accident.

In Derbyshire a similar attempt at reintroduction was made by the late Sir Francis Darwin, to whose son, Mr. E. L. Darwin, we are indebted for the following graphic account of the experiment :-

"My father (the late Sir Francis Darvin) possessed an estate in Derbyshire, which consisted of 
the wildest and most picturesque land, a great part of which was naturally wooded, and another part artificially planted with larch, Scotch fir, and spruce. About the year 1826 he received a present from the late Sir William Ingilby of a German Boar, and from Mr. Michaelis two Alpine boars and two sows. The German boar was a large, powerful animal, of a tawny red colour, and the others were a dusky black. It was my father's intention to turn them all out in the woods, and let them have the free run of ahout two hundred acres; but the red boar was found to be so utterly irreclaimable through his ferocity, that, so far as he was concerned, the idea was given up, and the black boars and sows only were allowed their liberty. A cross of the two breeds was, however, determined on, and in subsequent years the sorws produced both red and black progeny.

"Although most formidable-looking creatures, the Alpine boars were perfectly harmless, unless intentionally irritated, and I must allow that their tempers were occasionally tried by myself amongst others, when they could be teased from some safe spot. On such occasions they would stand with one foot much advanced, and the head drawn back, and the attitude was emphasized by a ferocious 'chopping' of the jaws, till the foam used to fall on the ground, and the great formidable tusks were alarmingly displayed. I only wonder now why the numerous blows on the head from large stones, which were a part of the performance, were never revenged when 
the recipient met me unexpectedly and no refuge was near. Brought up in this wild country, I carried a gun when very young, and as I never went into the woods without one, I suppose I felt comparatively safe. I recollect that one of our grooms, when making a short cut through a fern bed which existed on one part of the property, was unexpectedly charged by a sow, but he escaped by the hardest running. From her manner it was evident that she had young ones, and my father, myself, and the groom and keeper, went up the same afternoon-a Sunday it was-and we discovered a nest in the fern-bed, but could not go nearer than a few yards, as the sow stood at the entrance and forbade any further advance. The young pigs were seen a week or two afterwards, and they were all red-coloured, but with a few black up-and-down stripes. The two old boars gradually got to know my father, and they would take bread from his hand, and I have seen them rub their frothy snouts against his old shooting-jacket pocket when he has been sitting down, as if asking to be fed-which no doubt was their meaning.

"At one time there were a good many vipers and snakes on the property, but they gradually disappeared; and my father, attributing this to the presence of the boars, succeeded once in catching a full-grown viper, and, having enticed one of the boars into a shed, threw the viper down close to him. The viper, instead of attempting to escape, at once came to "attention," and the boar, after a 
preliminary "chop" or two, dashed at it. The viper seemed to strike him two or three times on the snout, but the boar, putting one foot on him, pulled him to pieces in a few seconds, and certainly did not suffer any subsequent inconvenience from the viper's attacks. Jack and Dick (the two black boars) died natural deaths, and their successors degenerated in size, and seemed gradually to become tame and spiritless; they have been extinct for forty years or so. The old red boar lived for some years confined in a large yard, and at enmity with everyone; a more untameable animal there could not be. He came to an undignified end, being fed and killed like his tame brethren. After death he was skinned and stuffed, and when I last saw him he was in the lumber room at the Priory, near Derby, and, like the celebrated wolf killed by the deerhound Gelert, he was "tremendous still in death." The head of one of his grandsons is or was in the Derby Museum, and a formidable-looking abject it is, with immense tusks. This descendant died from eating a poisoned rat which had been thoughtlessly thrown to him.

"The very last of the Sydnope boars was shot in the year 1837 , and the fact was recorded in verse, by one of the party, very humorously and successfully."

The exact date of the extinction of the Wild Boar in Britain us uncertain.

There were Wild Boars in Durham in 1531-33. In the Accounts of the Bursar of the Monastery of 
Durham for these years are several entries of payments made for bringing in Wild Boars; thus :-

1531. 28. Alarcii. Et Christifero Richardson, I aper; 6s. Su.

1533. Et in uno apro empto de 'Thoma Cottysfurth, $6 s$. Et in uno apro empto de Thoma Chepman, is

The price doubtless varying with the size and condition of the animal.

When Heniry VIII. visited Wulf hall, Savernake, the residence of the Seymours, in 1539 and I 543 , there were Wild Boars in the adjoining forest, as we learn from the "Household Book" of Edward Seymour, Earl of Hertford, some extracts of which have been printed in the Wiltshire Archooological Magazine for June, r875 (pp. r 7 I-I77).* The following: entries occur :-

"Paid to Morse and Grammatts for helpyng to take the wylde swyne in the forest . . . . . . . . . 4d.

And for 8 hempen halters to bynd their legs . . . . . 4d.

And for drink for them that helped to take them . . . 4\%.

Again:-

To Edmund Coke and Wm. Morse and other's for sekyng wilde swyne in the forest 2 days . . . 2s. 6 d.

To Thomas Christopher for his costes when he caryed the two wilde bores to the Court to my Lord att Wynsor, All-hallowen even . . . . . 3s.4 4 .

In 1617, it was still to be found in Lancashire; for when James I. in that year visited Sir Richard Hoghton, at Hoghton Tower, near Whalley, one of the dishes with which the royal banquet was more than once supplied was "Wild-boar pye." "†

* An interesting article ou Savernake Forest, by the Rev. Canon Jackson, will be found in the same Magazine for August, 1880 (pp. 26-44).

† Nicholls, "Progresscs, \&c., of James I.," vol. iii. p. 402. 
In the sane year the King hunted the Boar at Windsor. Adam Newton, in a letter to Sir Thomas Puckering, Bart., dated Deptford, Sept. 28, 16 I 7 , writes: "I was at Hampton Court on Sunday last, where the Court was indeed very full; King, Queen and Prince all residing there for the time. The King and Prince, after their coming from Theobalds this day se'mnight, went to Windsor to the hunting of the Wild Boar, and came back on Saturday." "*

In Westmoreland the last Wild Boar is said to have been killed near Staveley by a man named Gilpin, the country round being at that time all forest and fell. Close to the spot inclicated is an inn, still called "Wild Boar Inn," while the bridge over the beck is known as "Gilpin's Bridge." A tradition of the former existence of the Wild Boar in this neighbourhood is still current, but no date can now be assigned for the destruction of the last of its race. It is veferred to approximately as "about 200 years ago," which carries us back to the reign of Charles II., and this is the latest date at which I have been able to find any mention of this animal in a wild state in England. An old "Account Book of the Steward of the Manor of Chartley: Præses. Com. Ferrers," contains the following entry :-

"I683.-Feb. Pd. the cooper for a paile for ye wild swine...... 0-2-0"

This shows that the Wild Boar was not extinct in

* "The Court and Times of James I.," vol. ii. p. 34 .

+ It appears by an Inquisition 20 Eliz., that in this year William Gilpin held the manor of Over Starcley (see Nicholson, "Hist. and Antig. Westm. and Cumberl.," vol. i. p. I39). 
England so early as has been supposed-that is, previously to Charles I.'s attempt to reintroduce it into the New Forest.

Of the few English writers who have described the hunting of the Wild Boar as formerly practised in England, George Turbervile, a gentleman of Dorset-

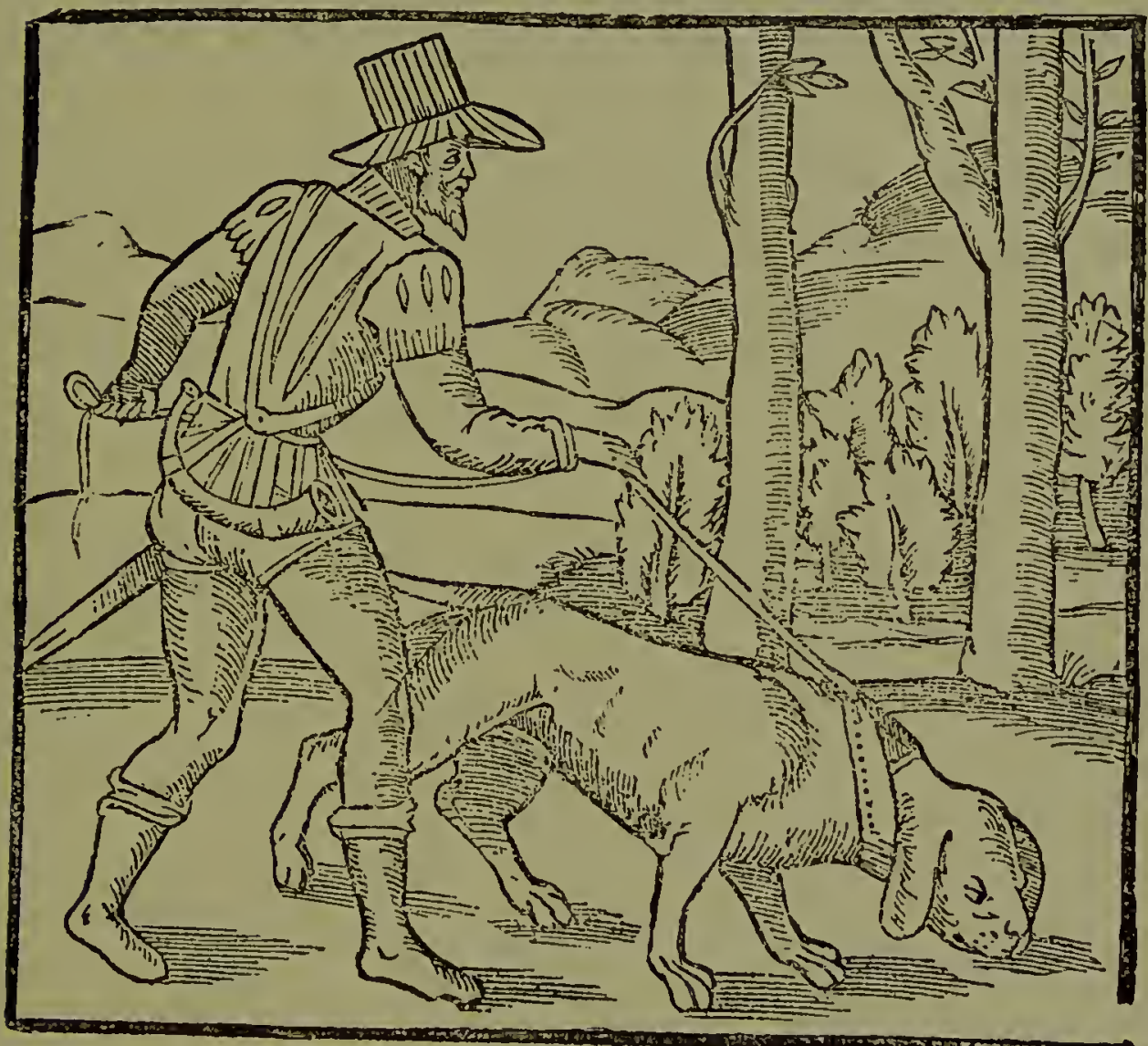

TRACKIYG A FILD BOAR. SIXTEENTII CENTURT.

shire, has furnished the best account in his "Booke of Hunting;" published in 1575 , a second edition of which appeared in 16Ir. In this work, which is now very rare, and of which we possess an imperfect copy, a long account is given of the "Wyld Bore" and its ways. "Although it ciught not," he 
siays, "to be counted among the beasts of venery which are chaseable with hounds, for he is the proper prey of a mastiffe and such like dogs, for as much as he is a heavy beast and of great force, trusting and asseying himselfe in his tuskes and his strength, and therefore will not so lightly flee nor inake chase before hounds. So that you cannot (by hunting of the Bore) know ye goodnesse or swiftness of them, and there withall to confesse a truth, I think it a great pitie to hunte (with a good kenell of hounds) at such chases : and that for such reasons and considerations as followe.

"First, he is the onely beast which can dispatch a hound at one blow, for though other beasts do bite, snatch, teare, or rend your houndes, yet there is hope of remedie if they be well attended; but if a Bore do once strike your hounde, and light betweene the foure quarter's of him, you shall hardly see him escape; and therewithall this subtiltie he hath, that if he be run with a good kenell of hounds, which he perceiveth holde in rounde and followe him harde, he will flee into the strongest thicket that he can finde, to the end he may kill them at his leisure one after another, the which I have seene by experience oftentimes. And amongst others, I saw once a Bore chased and hunted with fiftie good hounds at the least, and when he saw that they were all in full crie and helde in round together, he turned heade upon them, and thrust amiddest the thickest of them in such sorte that he slew sometimes sixe or seaven in [this] manner in the 
twinkling of an eye: and of the fiftie houndes there went not twelve sounde and alive to their masters houses.

"Againe, if a kennell of houndes be once used to hunte a Bore, they will become lyther, and will never willingly hunte fleeing chases againe. Forasmuch as they are (by him) accustomed to hunte with more ease and to find great scent. For a Bore is a beast of a very hot scent, and that is contrary to light fleeing chases which are hunted with more paine to the hound, and yet therwith do not leave so great scent. And for these causes, whosoever meaneth to have good hounds for an Hart, Hare, or Row-deare, let him not use them to hunt the Bore: but since men are of sundry opinions, and love to hunte such chases as lie moste commodiously aboute their dwelling places, I will here describe the propertie of the Bore and how they may hunt him, and the manner of killing him either with the sword or bore-speare, as you shall also see it set out in portrayture hereafter in his place."

Then follows a chapter "of the nature and subtiltie of the Bore," wherein we are told that "the Bore is of this nature, that when his dame doth pigge him, he hath as many teeth as ever he will have whiles he liveth, neither will thiir teeth any way multiply or encrease but onely in greatnesse and length. Amongst the rest they have foure, which (with the Frenchmen) are called défenses, and we call them tuskes or tusches, whereof the two lighest do not liurte when he striketh, but 
serve onely to whet the other two lowest: but with those lower tuskes, they stryke marvellously and kill oftentimes."

There is a difference between the wild and tame swine which, as may be supposed, did not escape the notice of huntsmen in olden times, when the pursuits of the chase alone engrossed their most inmediate attention. The information which they have left us on this and many other points is all the more valuable, as we have no longer the means of forming those comparisons which, from the experience of their lives, they were able to record with accuracy.

"The difference between the wild swine and our" hogs," says Turbervile, "is great, and that in sundry respects. First they are commonly blacke, or grisled, or streaked with blacke, whereas ours"are white, sanded, and of all coloures. Therewithal the wyld sywne in their gate do always set the hinder foote within the fore foote, orvery neare, and stay themselvesmore upon the toe than upon the heele, shutting theirclaws before close: and commonly theystrike their gards (which are their dew clawes) upon the ground, the whichsway outwards: and the sides of their hoofs do cut and pare the ground, the which our swine do not, for they spread and open their fore clawes leaving the ground between them: and they be commonly round and worne, leaning and staying more upon the heele, than upon the toe. Againe, they set not their hinder foote within their fore foote, and their gards fall straight upon the ground, and never shoyle or leane outwards: 
and they do beat down and soile the ground and cut it not. Also the soale of their feete is fleshy, and maketh no plaine print upon the ground as the wild swine do. There is likewise great difference in their rowtings : for a wild swine doth rowt deeper, because his snout is longer: and when they come into corne fieldes they follow a furrow, rowting and worming all along by some balke untill they come to the end. But tame swine rowte here and there all about the field, and never followe their rowting as the wild swine do. Likewise you may know them by the difference in their feedings in corne growne: for the wild swine beare downe the corne rounde about them, in one certaine place, and tame swine feede scattering here and there."

"The Wild Boar," says 'Turbervile, "has only one litter in the year."

In regard to the mode of hunting this animal as formerly practised in England, the plan seems to have been to follow it with relays of hounds until brought to bay, and then to rush in on foot or on horseback, and despatch it with sword or spear. Turbervile says :__ "If he stand at bay, the huntsmen must ryde in unto him as secretly as they can without much noyse, and when they be neare him, let them cast round about the place where he standeth, and run upon him all at once, and it shall be hard if they give lim not one skotch with a sword or some wound with a bore-speare: and let them not strike lowe, for then they shall commonly hit him on the snoute, because he watcheth to take 
all blowes upon his tuskes or thereabouts. But let them lift up their hands high and strike right downe; and let them beware that they strike not towards their horses but that other way; for on that side that a Bore feeleth himself hurte, he turneth head strayght waies whereby he might the sooner hurt or kill their horses if they stroke towards them. And if they lie in the plaine, then let them cast a cloake about their horses, and they maye the better ricle about the Bore, and strike at him as they passe; but stay not long in a place.

"It is a certaine thing experimented and found true, that if you hang belles upon collers about your. houndes necks, a Bore will not so soone strike at them, but flee endwaies before them, and seldome stand at bay."

In France, where the sport of Wild Boar hunting is still kept up in the olden style, different names are given to the animal at different ages. While quite young, when it is striped, it is called la livrée, and marcassin; in the autumn, when the stripes disappear and it assumes a reddish brown colour, it is termed bêle rousse and bête de compagnie (from keeping with the herd), names which are retained until two years old; from two to three years old it is called ragot, a word the etymology of which is unknown; * from three to four, sanglier à son tiers-an, or simply tiers an; r.rom four to fixe, quartanier; from five to six, quintanier and vieus sanglier. After this age, when both sexes become quite grey, the ears, * See Rolland, "Famro Populaira de la l'rance," P. 75. 
legs, and tail only remaining black, it is called grand vieur sanglier and solitaire.

The rvinter coat of the Wild Boar is quite different to that which he wears in summer. The entire body in winter is clothed with down, over which comes a thick coat of coarse hair, forming a stiff mane of long bristles dorm the neck and shoulders. This is all shed as the summer approaches, when, with a smooth coat and no bristles, he looks quite a different animal. 'T'o see him at his best it is needless to say he should be viewed in winter. His appearance is then extremely picturesque, with his short romnd black ears standing

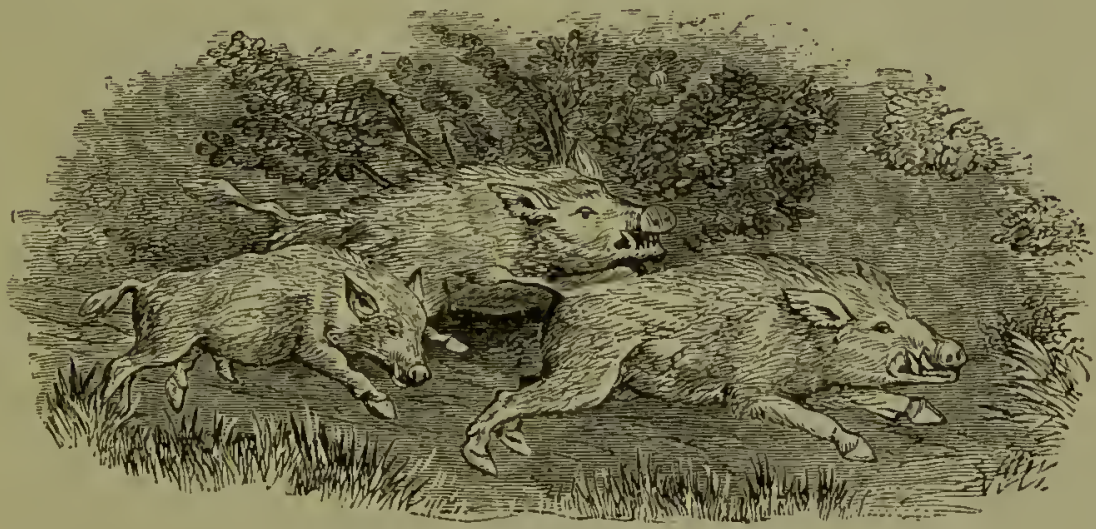

GROUP OE TILD BO.IRS.*

erect through his stiff grey mane; high shoulders, drooping towards the tail; his black legs almost as fine as those of a deer, denoting speed and activity ; and a tail which he nervously twitches while champing his tusks and darting "mischief" in every look of his small twinkling eyes.

The tail, it should be observed, is never curled, as frequently, though erroneously, represented in pictures,

* From a carved horn in possession of the author. 
but is perfectly straight, with a tuft at the end, not unlike that of the bison, and is carried erect when ruming.

Mr. F. H. Salvin, to whom reference has been already made, kept a Wild Boar for six or seven years, which was given him by H.H. the Maharajalt Dhuleep Singh, and came originally from Syria. 'This animal, a female, became remarkably tame, and would follow her owner about like a dog. In Land and Water of January I 2, I 867 , he gave an interesting account of her, which is ton long to be quoted here in extenso, but from which we extract the following particulars :-

"She follows me almost daily in my walks like a dog, to the great astonishment of stranger's. Of course I only take her out when the crops are too low to be injured; during the spring and summer months I merely take her for a run in the park, where she can do no harm. No dog can be more obedient to the whistle than she is. In the heat of summer she is fond of a swim, and has followed me in a boat to a great distance. I always have her belled, to hear where she is in the woods, and the bell, which is a good sheep's bell, is fastened round her neck with a strap and buckle. This was of use last autumn, for upon one occasion I lost her for a night or two by her remaining behind with her young ones amongst the acorns; and when I found her by the bell's sound, I was amused to see the immense quantity of rushes which she had collected in a snug dry spot for a lair for herself and family. 
Her leaping powers are extraordinary, over water or timber. On one occasion she cleared some palings three feet ten inches in height. As she had young only in the summer time, I suspect they breed but once a year in the wild state."

This confirms the statement of Turbervile to the effect that the Wild Boar produces only one litter in the year.

It was formerly the custom on Christmas Day at Queen's College, Oxford (whether still observed or not, we cannot say), to bring into hall a boar's head

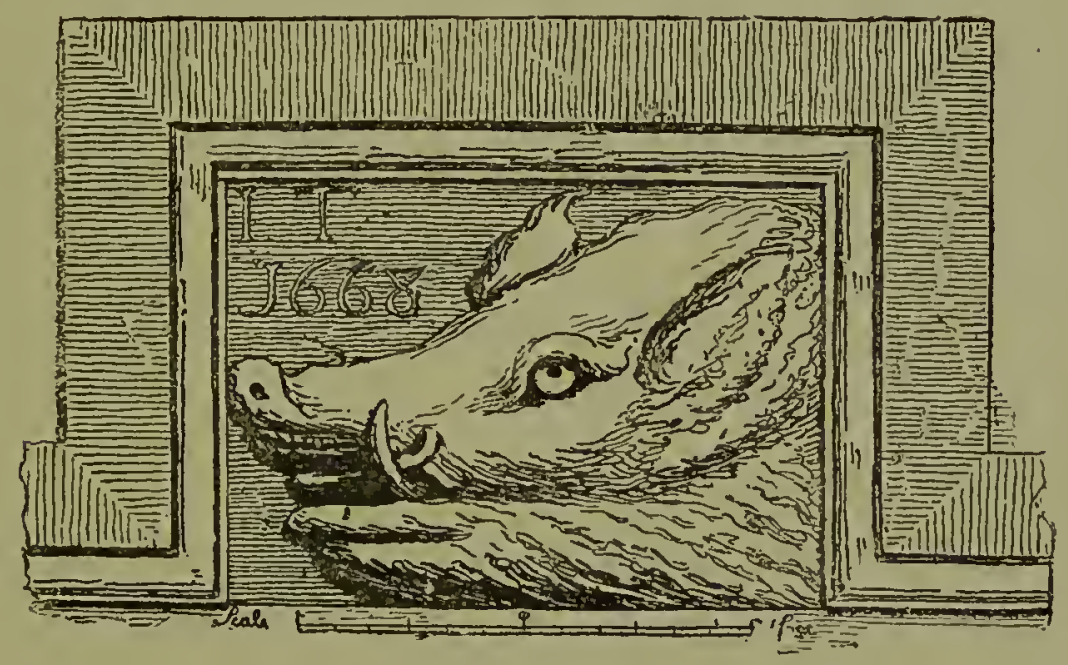

BOAR IX EAST CIIE.IP.

with great ceremony and song, as described by Aubrey in one of his MSS. preserved in the Ashinolean Museum. Tradition represents this usage of Queen's as a commemoration of an act of valour performed by a student of that college, who, while walking in the neighbouring forest of Shotover, and reading Aristotle, was suddenly attacked by a wild boar. The furious beast came open-mouthed upon the 
youth, who, however, very courageously and with a happy presence of mind, is said to have "rammed in the volume and cried Cirreum est," fairly choking the savage with the sage.*

We can scarcely dip into the lisstory of the Wild Boar in days gone by withont being reminded of the "Boar's Head," in Eastcheap, so liappily referred to by Shakespeare, and so pleasantly descanted on by Goldsmith in his "Reverie at the Boar's Head Tavern;" and we are tempted to give an illustration of this famous sign, in reduced facsimile from the engraving in Pennant's "London." That author thus alludes to it:- "A little higher up on the left hand is Eastcheap, immortalized by Shakespeare as the place of rendezvous of Sir John Falstaff and his merry companions. Here stood the Boar's Head tavern; the site is now covered with modern houses, but in the front one is still preserved the memory of the sign, the Boar's Mead cut in stone. Notwithstanding the house is gone, we shall laugh at the humour of the jovial knight, his hostess, Bardolph, and Pistol, as long as the descriptive pages of our great dramatic writer exist in our entertained imagination."

Hone, in his "Year Book," gires a brief account of a visit which he paid to this memorable hostelry. "I could not," he says, "omit a sight of this remarkable place; but upon my approach to Eastcheap, the inhabitants were fled, the house shut up, and instead of an half timber building, with one story projecting * Wade's "Walks in Oxford," I817, rol. i. p. 167. 
over the other, as I expected, the edifice was modern, with a date in the front of 1668 . I immediately concluded that the old house was burnt down by the great fire." Goldsmith's latest editor, Colonel Cunningham, in a note to the essay above referred to, assures us that this was so.

Hone, however, continued his researches. On each side of the doorway he observed "a vinebranch carved in wood, rising more than three feet from the ground, loaded with leaves and clusters; and on the top of each a little Falstaff, eight inches high, in the dress of his day." This induced him to make further inquiry, when he ascertained that the place had been sold by auction three week's before, at Garraway's coffee-house ; that the purchaser was a stranger, and had the keys; and that a sight of the premises could not be obtained. "There is nothing," he says, "more difficult than to find out a curiosity which depends upon others, and which nobody regards. With some trouble," he continues, "I procured a sight of the back buildings. I found them in that ancient state which convinced me that tradition, Shakespeare and Goldsmith, were right; and could I have gained admission into the premises of mine hostess, Mistress Quickly, I should certainly have drank a cup of sack in memory of the bulky knight."

There was another and more ancient hostelry

* The date of his visit is not stated, but the date of his Preface to "The Year Book," in which his account is printed (under "December 3 "), 
called the "Boar's Mead," though less celebrated than the one just mentioned. It was situate in Southwark, and was standing in Henry the Sixth's time. It is referred to in the "Paston Letters," in a letter from Henry Wyndesore to John Paston, dated August 27, I 458. The writer says, - "Please you to remembre my maistre at your best leiser, wheder his old promise shall stande as touchyng my preferrying to the 'Boreshed' in Suthwerke." **

It is in this same collection that we find mention made of the use of "boar-spears" in Norfolk, in the fifteenth century, first in a petition of John Paston to the King and Parliament, in 1450, touching his expulsion from Gresham by Lord Molyns, whose retainers held forcible possession of this manor "with bore-speres, swordes, and gesernys" (battle-axes); and again in a similar petition of Walter Ingham in I $454 .{ }^{\dagger}$

The boar-spear of those days was very different from the spear now used by boar-hunters in India. Nicholas Cox, in "The Gentleman's Recreation," first published in 1674, thus describes it:- "The hunting spear must be very sharp and broad, branching forth into certain forks, so that the boar may not break through them upon the huntsman." The modern Anglo-Indian spear is from six to eight feet long; the shaft of bamboo weighted with lead; the spear-head a broad and stout blade.

* "The Paston Letters," ed. Gairdner, vol. i. p. 431 .

† Op. cit., vol, i., pp. 107, $27 \mathrm{I}$. 


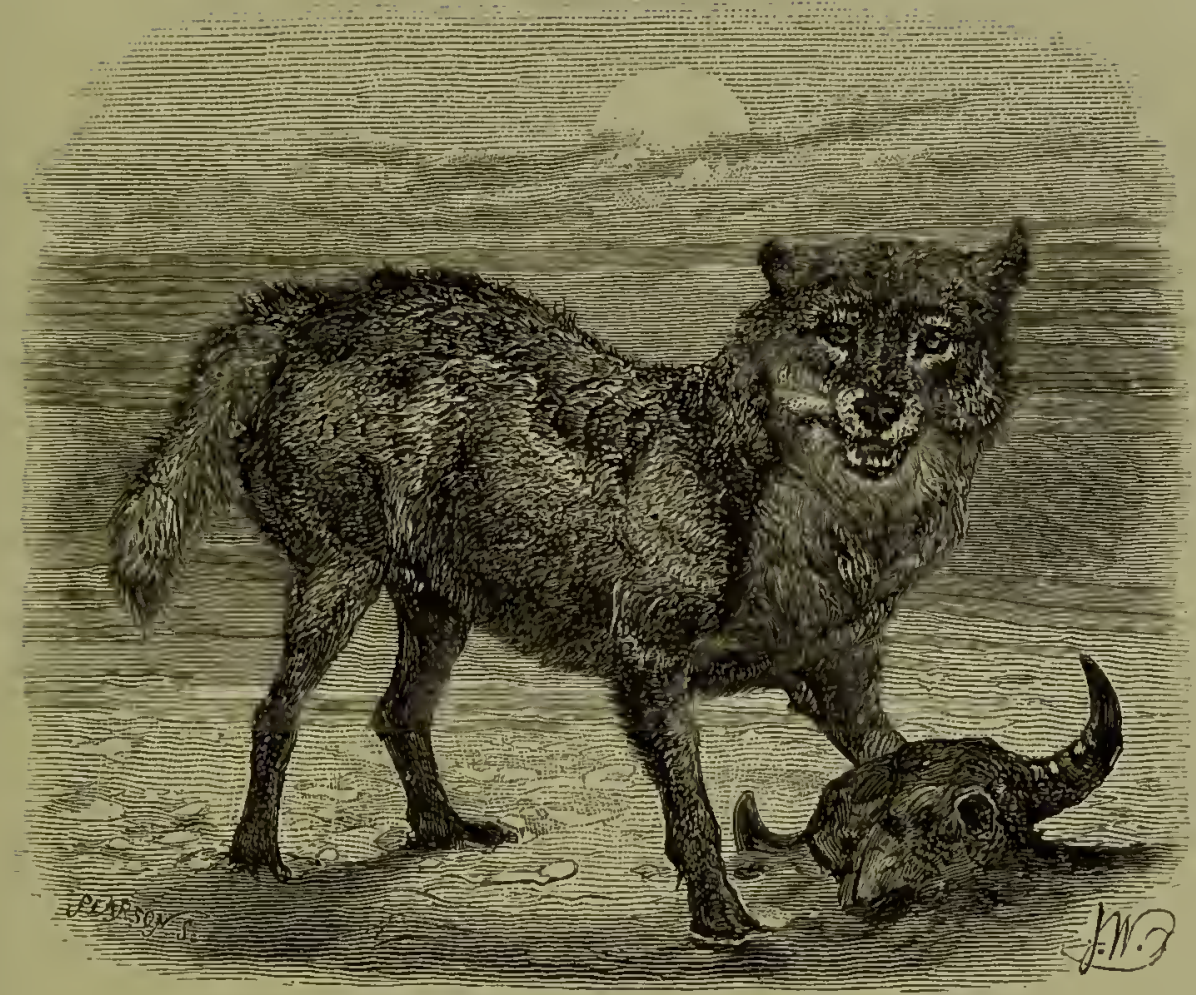

\section{THE WOLF.}

\section{Canis lupus.}

OF the five species which come within the scope of the present work, the Wolf was the last to disappear. On this account, partly, the materials for its history as a British animal are more complete than is the case with any of the others.

To judge by the osteological remains which the researches of geologists have brought to light, there was perhaps scarcely a county in England or Wales in which, at one time or another, Wolves did not 
abound, while in Scotland and Ireland they must have been even still more numerous.

The vast tracts of unreclaimed forest land which formerly existed in these realms, the magnificent remmants of which in many parts still strike the beholder with awe and adiniration, afforded for centuries an impenetrable retreat for these animals, from which it was well-nigh impossible to drive them. It was not, indeed, until all legitimate modes of hunting and trapping had proved in vain, until large prices set upon the heads of old and young had alike failed to compass their entire destruction, that by cutting down or burning whole tracts of the forests which harboured them, they were at length effectually extirpated.

In the course of the following remarks it is proposed to deal, first, with the geological evidence of the former existence and distribution of Wolves in the British Islands ; secondly, with the historical evidence of their survival and gradual extinction.

Under the latter head it will be convenient to arrange the evidence separately for England and Wales, Scotland, and Ireland: and, as regards England and Wales, to subdivide the subject chronologically into (I) the Ancient British Period; (2) the Anglo-Saxon Period; and (3) the period intervening between the Norman Conquest and the reign of Henry VII.

In this reign, it is believed, the last trace of the Wolf in England disappeared, since history thereafter is silent on the subject. In Scotland and 
Treland, however, this was by no means the case, as, later on, we shall be able to show.

\section{Geological Evidence.}

Owing to the great similarity which exists between the skeleton of a Wolf and that of a large Dog, such as would be used in the chase, it is very difficult to distinguish between them. Professor Owen, in his

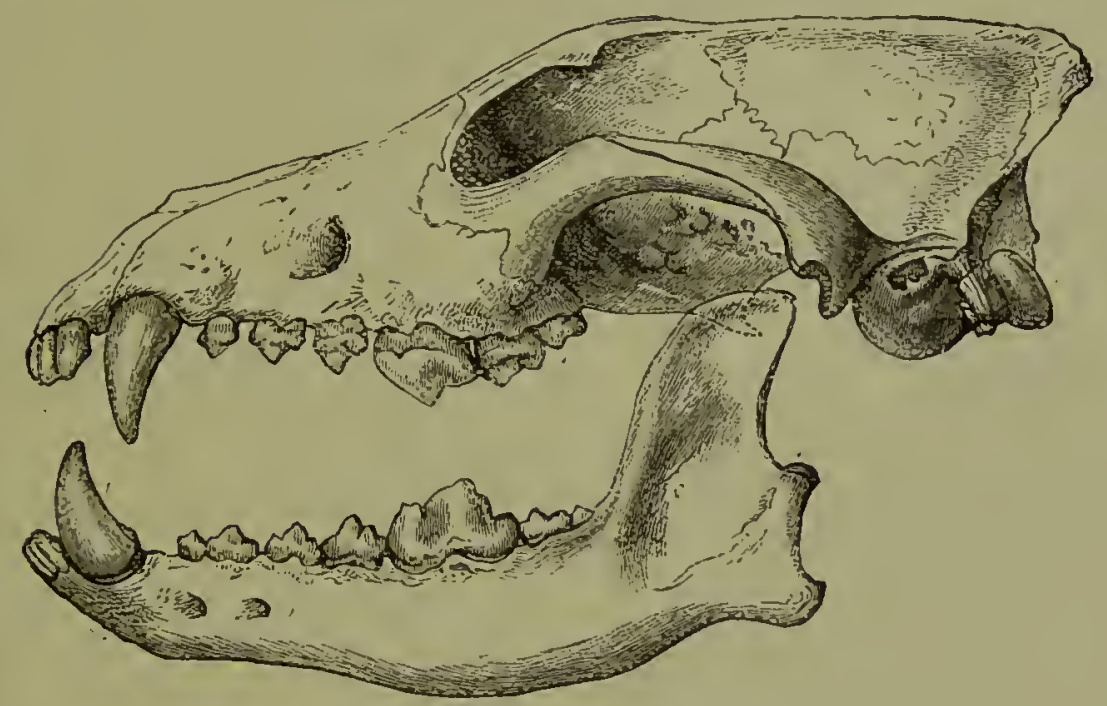

SKULL OF WOLF. (

"British Fossil Mammals," has remarked upon this difficulty, and, following Cuvier, has pointed out the chief distinguishing characters which may be relied upon for identification, and which lie chiefly in the skull. He says :-_"The Wolf has the triangular" part of the forehead behind the orbits a little narrower and flatter, the occipito-sagittal crest longer and loftier, and the teeth, especially the canines, proportionately larger."**

* Compare the crania of the Wolf here figured (pp. I2O, 121) with those of the Dog, upper and under surfaces, given by Professor Flower in his "Ostcology of the Marmmalia," pp. 1 13 , I 16 (Ist ed.). 
So far as we have been enabled to collect the evidence, it would appear that undoubted remains of the Wolf have been found in the following localities, for a knowledge of many of which we are indebted to Professor Boyd Dawkins' able paper, "On the Distribution of the British Post-Glacial Mammals," published in the Quarterly Journal of the Geological Society, vol. xxv. I 869, p. 192.

Berkshire. -Windsor (Mus. Geol. Survey).

Derbyshire.-Pleasby Vale (Mus. Geol. Survey); Windy Knoll, Castleton (Dawlins, "Quart. Journ. Geol. Soc." xxxi. p. 246, and xxxiii. p. 727); Creswell Crag Caves (Mello and Busk, “Quart. Journ. Geol. Soc." xxxi. p. 684; Darkins, op. cit. xxxii. p. 248, and xxxiii. pp. 590 and 602.)

Devorshire.-Bench Cave, Brixham (W. A. Sanford); Kent's Hole, Torquay (Mus. Geol. Soc., Mus Roy. Coll. Surg., and Mus. Oxford); Oreston, near Plymouth (Brit. Mus. and Mus. Geol. Soc.; Owen, "Brit. Foss. Mamm." p. 123).

Glanorganshire.-Gower, Bacon's Hole (Mus. Swansea; Falconer, "Palæont. Mem." ii. pp. I83, 325, 340, 349, 501); Bosco's Hole (Mus. Swansea; Falconer, tom. cit. pp. 5 10, 589 ); Crow Hole (Mus. Swansea; Falconer, tom. cit. p. 519); Deborah Den (Mus. Swansea; Falconer, tom. cit. p. 467); Long Hole (Falconer, tom. cit. pp. 400, 525, 538); Minchin Hole (Brit. Mus.; Mus. Swansea); Paviland (Mus. Oxford and Swansea ; Owen, "Brit. Foss. Mamm." p. I24); Ravenscliff (Falconer, tom. cit. p. 519); Spritsail Tor (id. pp. 179, 462, $477,522)$.

Gloucestershire.-Tewkesbury (Owen, "Brit. Foss. Manm."). Kent.-Murston, Sittingbourne (Mus. Geol. Survey).

Essex.-Valley of the Roding, Ilford (Sir A. Brady).

Norfork.-Denver Sluicet (Mius. Geol. Cambr.).

Oxfordshire.-Thame (Coll. Codrington, "Quart. Journ. Gcol.

Soc." xx. p. 374).

Somersetsurne.-Benwell Cave (W. Borrer); Blendon (Mus.

Taunton); Hutton (Mus. Taunton); Sandford Hill (Mus.

Taunton); Uphill (Mus. Bath and Taunton); Woley Hole (Mus. Oxford, Taunton, and Bristol).

† A landscape by R. W. Fraser "On the Ouze near Denver Sluice" was exhibited at the Royal Academy in I877, No. 794. The locality is a few miles to the Soutl of Downham Market, and just below wherc the old and new Bedford river's run into the natural stream. 
Sussex.-Bracklesham (Brit. Mus. and Mus. Chichester); Pevensey* ("Sussex Archrool. Coll." xxiv. p. I60.)

Wiltsirne.-Vale of Kennet (" Sussex Archæol." tom. cit.).

Yorksirire.-Bielbecks (Mus. York; " Phil. Mag." vol. vi. p. 225);

Kirkdale (Brit. Mus., Mus. Geol. Soc. and Roy. Coll. Surg;

Buckland, "Trans. Roy. Soc." I 822 ; Clift, id. I823, p. 90).

We have here a dozen counties in different parts of England and Wales, north, south, east, and west, which show clearly from their position how very generally distributed the Wolf must formerly have been.

The geological record, however, is but an imperfect one in showing the distribution of the Wolf in bygone times, for to the localities above mentioned might be added numerous others in which we know from history that this animal formerly abounded. The forest of Riddlesdale in Northumberland; the great forests of Blackburnshire and 13owland in Lancashire; Richmond Forest, Yorkshire; Sherwood Forest, Nottinghamshire; Savernake Forest, Wilts ; the New Forest; the forests of Bere and Irwell, and many others, are on record as former strongholds of these ferocious animals. To these we shall have occasion to refer later when dealing with the historical evidence.

Unlike other extinct British animals, the Wolf apparently has not deteriorated in size, for the fossil bones which have been discovered, as above mentioned, are not larger, nur: in any way to be distinguished from those of European wolves of the present day.

* In r85 m many skulls of Wolves were taken out of a disused mediæral well at Pevensey Castle. 
Historicat Evidence-Englani.

Ancient British Period. - Dio Nicseus, speaking of the inhabitants of the northern parts of this island, tells us they were a fierce and barbarous

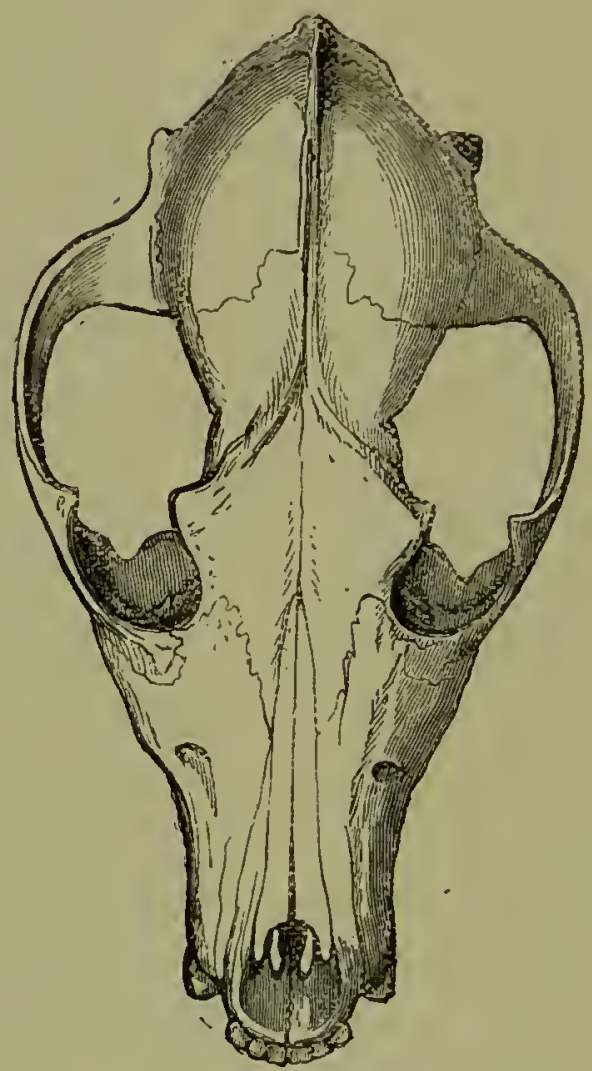

CRANIUA OF WOLF. URPER SURFACL. ( $\frac{1}{3}$ NAT. SIZL.)

people, who tilled no ground, but lived upon the depredations they committed in the southern districts or upon the food they procured by hunting. Strabo also says (lib. iv.) that the dogs bred in Britain were highly esteemed upon the Continent on account of their excellent qualities for hunting, and these qualities, he seems to hint, were naturai to 
them, and not the effect of tutorage by their foreign masters. Wolf-hunting appears to have been a favourite pursuit with the ancient Britons. Mempricius or Memprys, one of the immediate descendants of Brutus, who reigned until B.C. 980, fell a victim

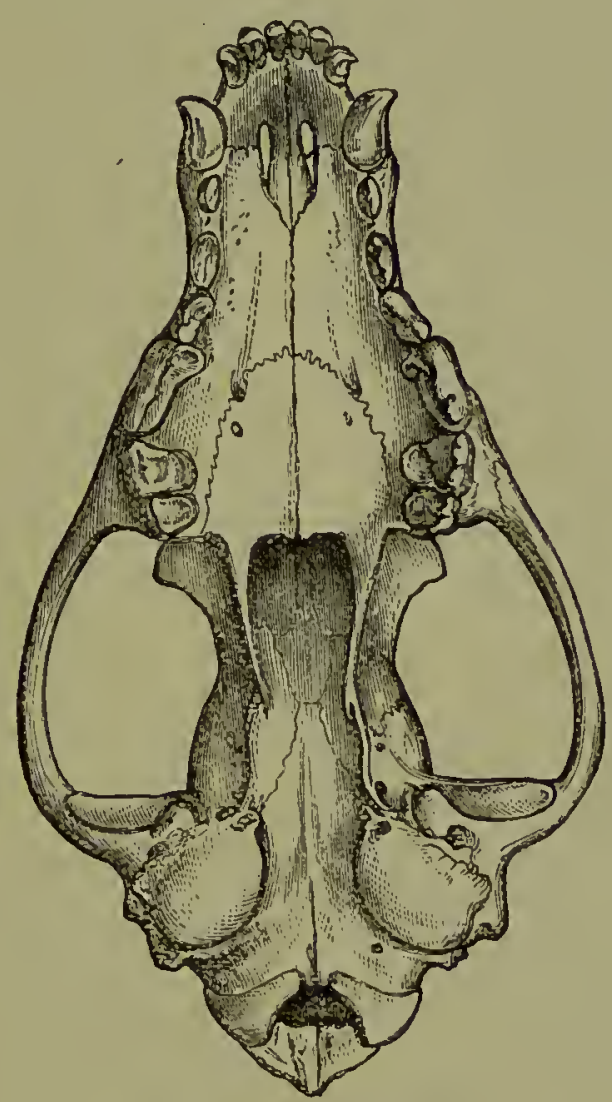

CRATIUA OF TOLF. UNDER SURFACE. ( $\frac{1}{3}$ NAT. SIZL.)

in that year to the Wolves which he delighted to pursue, and was unfortunately devoured by them.

"Hys brothir he slwe--

For tyl succede tyl hym as kyng.

It happynde syne at a huntyng

Wytht wolwys hym to weryde be ;

Swa endyit his iniquite."

Wyntownis Cronylill, i. 1). 54 .

Blaiddyd, another British monarch (B.C. 863), who seems to have been learned in chemistry, is said to 
have discovered the medicinal properties of the Bath mineral waters, by observing that cattle when attacked and wounded by the Wolves went and stood in these waters, and were then healed much sooner then they would have been by any other means. From this it may be inferred that Wolfhunting was found by the ancient Britons to be a necessary and pleasurable, yet dangerous, pursuit.

We do not find, says Strutt, * that during the establishment of the Romans in Britain, there were any restrictive laws promulgated respecting the killing of game. It appears to have been an established maxim in the early jurisprudence of that people, to invest the right of such things as had no master with those who were the first possessors. Wild beasts, birds, and fishes became the property of those who first could take them. It is most probable that the Britons were left at liberty to exercise their ancient privileges; for had any severity been exerted to prevent the destruction of game, such laws would hardly have been passed over without the slightest notice being taken of them by the ancient historians.

Anglo-Saxon Period.-As early as the ninth century, and doubtless long before that, a knowledge of hunting formed an essential part of the education of a young nobleman. Asser, in his "Life of Alfred the Great," assures us that that monarch before he was twelve year's of age "was a most expert and active hunter, and excelled in all the branches of that most * "Sports and Pastimes of the People of England." 
noble art, to which he applied with incessant labour and amazing success." Hunting the Wolf, the Wild Boar, the Fox, and the Deer, were the favourite pastimes of the nobility of that day, and the Dogs which they employed for these various branches of the sport, were held by them in the highest estimation.

Suchravages did the Wolves commit during winter,

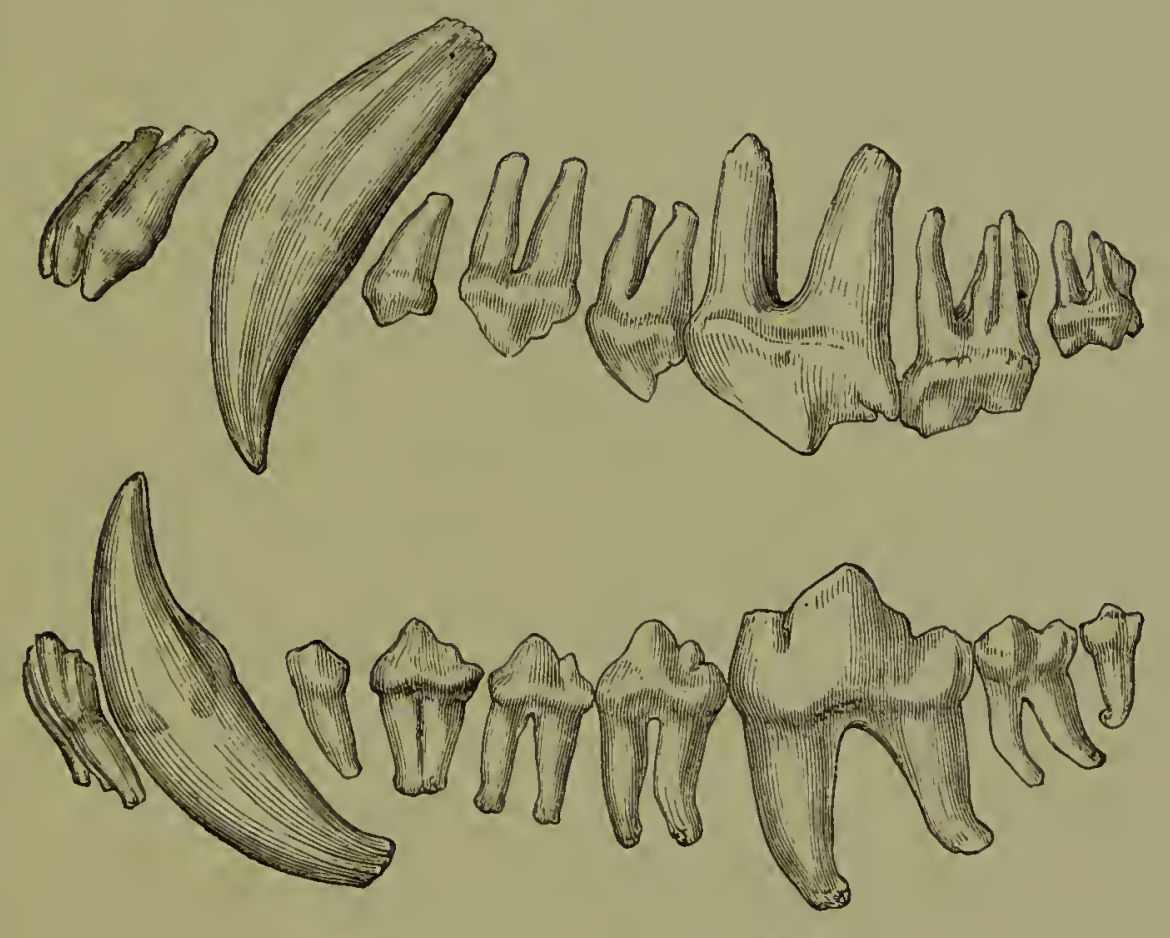

TEETII OF TOLF. NATURAL SIZE.

particularly in January when the cold was severest, that the Saxons distinguished that month by the name of "Wolf month."

"The month which we now call January;" says Verstegan, "they called 'Wolf monat,' to wit, 'Wolf moneth,' because people are wont always in that month to be in more danger to be devoured of Wolves than in any season else of the year; for that, through the extremity of cold and snow, these ravenous 
creatures could not find of other beasts sufficient to feed upon."**

The Saxons also called an ontlaw "wolfs-head," + as being out of the protection of the law, proscribed, and as liable to be killed as that destructive beast. "Et tunc goment caput lupinum, ita quod sine judiciali inquisitione rite pereant." $†$

In the "Penitentiale" of Archbishop Egbert, drawn up about A.D. 750, it is laid down (lib. iv.) that, "it" a wolf shall attack cattle of any kind, and the animal attacked shall die in consequence, no Christian may touch it."

It is to the terror which the Woif inspired among our forefathers that we are to ascribe the fact of kings and rulers, in a barbarous age, feeling proud of bearing the name of this animal as an attribute of courage and ferocity. Brute power was then considered the highest distinction of man, and the sentiment was not mitigated by those refinements of modern life which conceal but do not destroy it. We thus find, amongst our Anglo-Saxon kings and great men, such names as Ethelwulf, "the Noble Wolf ;" Berthwulf, "the Illustrious Wolf ;" Eadwulf, "the Prosperous Wolf;" Ealdwulf, "the Old Wolf."

In Athelstan's reign, Wolves abounded so in Yorkshire that a retreat was built by one Acehorn, at

* “Restitution of Decayed Intelligence," p. 64 (ed. 1673).

+ Ang.-Sax. Wulvesheofod, that is, having the head of a Wolf. In ro4I, the fugitive Godwin was proclaimed IVulveshenfod, a price being set upon his head. The term was in use temp. Henry II.

+ Bracton, "De legibus et consuetudinibus Anglia," lib. iii. tr. ii. c. II (1 569). See also Knighton, "De Erentibus Anglie," in Twysden's "Historix Anglicanx Scriptores Decem," p. 2356 (1652). 
Fliston, near Filey, in that county, wherein travellers. might seek refuge if attacked by them.

Carnden says :- "More inward stands Flixton, where a hospital was built in the time of Athelstan, for defending travellers from Wolves (as it is word for word in the public records), that they should not be devoured by them."* It is currently believed that a farmhouse between the villages of Flixton and Staxton now stands on the site of this hospital. It was restored and confirmed in 1447 by the name of Canons Spittle, and was dissolved about I 535 . The farm is still called Spittal Farm, and a small stream running by it is called Spittal Brook. ${ }^{\dagger}$

When Athelstan, in 938, obtained a signal victory at Brunanburgh over Constantine, King of Wales, he imposed upon him a yearly tribute of money and cattle, 'to which was also added a certain number of "hawks and sharp-scented dogs, fit for the hunting" of wild beasts." $\neq$ His successor, Edgar, remitted the pecuniary payment on condition of receiving innually from Ludwall (or Idwal\|), the successor of Constantine, the skins of three hundred Wolres. if

* Camclen, "Britannia," tit. Yorkshire, vol. ii. p. 902.

t 'This information was communicated to the author by the Rev. Henry Blane, of Folliton Rectory, Ganton, York.

William of Malnesbury, "Hist. Reg. Anglorum," lib. ii. c. 6.

\$ Cf. Holinshed's "Chronicles," vol. i. p. 378 (4to ed. ISo7), and Selden's Notes to Drayton's "Polyulbion," Song ix.

II C'f. Camden's "Britannia," tit. Merionethshire, vol. ii. p. 785.

William of Malmesbury, op. cit. lib. ii. c. 8. Sec-also the quaint remarks on this subject by T'aylor, the Water Poet, in his "Journey through Wales," I652 (pi. 3I, 32, Halliwell's edition, I859). The value of a wolf-skin in Wales, as fixed by the Code of Taws made by Howel Dha in the nintl century, was eightpence, the same value
being set mpon an otter-slin. 
We do not find, indeed, that the hawks and hounds were included in this new stipulation, but it does not seem reasonable that Edgar, who, like his predecessor, was extremely fond of field sports, should have remitted that part of the tribute.*

It is generally admitted that Edgar relinquished the fine of gold and silver imposed by his uncle Athelstan upon Constantine, and claimed in its stead the annual production of 300 wolf-skins, because, say the historians, the extensive woodlands and coverts, abounding at that time in Britain, afforded shelter for the Wolves, which were exceedingly numerous, especially in the districts bordering upon Wales. By this prudent expedient, in less than four year's, it is said, the whole island was cleared of these ferocious animals, without putting his subjects to the least expense.t But, as Strutt has observed, + "if this record be taken in its full latitude, and the supposition established, that the Wolves were totally exterminated in Britain during the reign of Edgar, more will certainly be admitted than is consistent with the truth, as certain documents clearly prove." The words of William of Malmesbury on the subject are to this effect, that " he, Edgar, imposed a tribute upon the King of Wales, exacting yearly 300 Wolves. This tribute

* Strutt, "Sports and Pastimes."

† It is singular that the same expedient has been resorted to in modcrn times, and with considerable success. In the accounts of Assinniboia, Red River Territory, there is an entry of payment for Wolves' heads; and in I 868 the State of Minncsota paid for Wolrcs' scalps I I,300 dollars, at the rate of ro dollars apiece.

‡ "Sports and Pastimcs." 
continued to be paid for three years, but ceased upon the fourth, because, 'nullum se ulterius posse invenire professus,' it was said that he could not find any more."

\section{"Cambria's proud Kings (tho' with reluctance) paid Their tributary wolves; head after head, In full account, till the woods yield no more, And all the rav'nous race extinct is lost."}

Somertile's Chace.

But this must be taken to refer only to Wales, for in the first place it can hardly be supposed that the Welsh chieftain would be permitted to hunt out of his own dominions, and in the next place there is abundant documentary evidence to prove the existence of Wolves in England for many centuries later.

Holinshed, who gives a much fuller account, says : $\dagger$ - "The happie and fortunate want of these beasts in England is vniuersallie ascribed to the politike government of King Edgar, who to the intent the whole countrie might once be clensed and clearelie rid of them, charged the conquered Welshmen (who were then pestered with these ranenous creatures aboue measure) to paie him a yearlie tribute of woolfes skinnes, to be gathered within the land. $\mathrm{He}$ appointed them thereto a certaine number of 300 , with free libertie for their prince to hunt and pursue them ouer all quarters of the realme; as our chronicles doo report. Some there be which write

\footnotetext{
* "Hist. Reg. Anglorum," lib. ii. cap. 8. See also Wynne's "Caradoc," p. 5r.

† "Chronicles of England, Scotland, and Ireland," (ed. 4to, I 807), vol. i. p. 378 , bk. iii. chap. iv. : 'Of Savage Bcasts and Vermines.'
} 
how Ludwall, prince of Wales, paid yearelie to King Edgar this tribute of 300 woolfes, whose carcases being brought into Lloegres, were buried at Wolfpit, in Cambridgeshire, and that by meanes thereof within the compasse and terme of foure yeares, none of these noisome creatures were left to be heard of within Wales and England. Since this time, also, we read not that anie woolfe hath beene seene here that hath beene bred within the bounds and limits of our countrie: howbeit there haue beene diuerse brought over from beyond the seas for greedinesse of gaine, and to make monie onlie by the gasing and gaping of our people vpon them, who conet oft to see them, being strange beasts in their eies, and sildome knowne (as I haue said) in England."

This event is related somewhat differently by the Welsh historians. "In the year 965," says Powel, "the country of North Wales was cruelly wasted by the army of Edgar, King of England; the occasion of which was, the non-payment of the tribute that the king of Aberffraw (North Wales), by the liwws of Howel Dha, was obliged to pay to the king of London (England). But at length a peace was concluded upon these conditions, that the king of North Wales, instead of money, should pay to the king of England the tribute of 300 Wolves yearly; which creature was then very pernicious and destructive to England and Wales. This tribute being duly performed for two years, the third year there were none to be found in any part of the island, so that afterwards the prince of North Wales became exempt 
fiom paying any acknowledgment to the king of England."

The amonnt of the original tribute commuted for this tax of Wolves, the time when that tribute was appointed, and the cause for which it was imposed, are altogether circumstances not very generally understood. It is vaguely imagined to have been a degrading tax paid by the people of Wales to the English monarch, in token of their subjection to his sovereignty as their conqueror. "This," says Powel, " is not the fact; it arose from a local cause : from one of those cruel dissensions among the native princes which too often disgrace the Welsh annals, and to settle which the weakest never failed to invite the aid of foreign force.

About the year 953, Owen, the son of Griffith, was slain by the men of Cardigan; and Athelstane, upon this pretext, entering with an army into Wales, imposed an annual tribute upon certain princes to the amount of $£ 20$ in gold, $£ 300$ in silver, and 200 head of cattle, but which was not observed by these Welsh princes, as appears by the laws of Howel Dha, wherein the levy is appointed. It is there decreed that the Prince of Aberffraw should pay no more to the English king than $£ 66$ tribute, and even this sum was to be contributed to the prince of Aberffraw by the princes of Dinefawr and Powis, upon whom this tax was virtually imposed. The principality of Dinefawr, it may be observed, included Cardigan, by the men of which district the alleged crime had been committed; and Powis, which was close to the 
English borders, was apparently implicuted in the same offence."

Hence it appears the tax was a local fine imposed upon these two princes, only that the prince of North Wales was made answerable for its due performance. The tax existed therefore, though but nominally, for the space of two-and-thirty yearsnamely, from the time of Athelstane to Fdgar-when the above recorded commutation of the tribute took place, and for the fulfilment of which condition it is apparent the prince of North Wales was again made answerable.

That the principality of Wales was, by this salutary means, delivered in a great measure from the pest of Wolves may be conceived. In this the histories of the Welsh agree; but there is some shade of difference in their conclusions as to the utter extermination of the race; and it is now believed that they were not entirely destroyed in Wales till years after. Owen, in his "Cambrian Riography," says it was not till forty-five years after.*

Drayton, in his "Polyolbion" (Song ix.), has thus commemorated the wisdom of Edgar's policy :-

“Thrice famous Saxon king, on whom Time ne'er sliall prey.

O Edgar! who compell'dst our Ludwall hence to pay Three hundred Wolves a year for tribute unto thee; And for that tribute paid, as famous may'st thou be, O conquer'd British king, by whom was first destroy'd The multitude of Wolves that long this land annoy'd."

* "Iago ap Idwal Voel, king of Gwynedd, from A.D. 948 to 979. From 948 to 966 he reigned jointly with his brother Jevav. In 962 Edgar made him pay tribute of wolves' heads; and in forty-five years after, all these animals were destroyed." 
The learned Dr. Kay* acquiesced in the vulgar opinion of the extinction of Wolves in England by King Edgar, and in his work on "British Dogs," published in 1570 , treating of the sheep-dog (Pastoralis) he says: "Sunt qui scribunt Ludwallum Cambria" principem pendisse annuatim Edgaro regi 300 luporum tributi nomine, atque ita annis quatuor omnem Cambriam, atque adeo omnem Angliam, orbasse lupis."

"Regnavit autem Edgarus circiter annum 959, a quo tempore non legimus nativum in Anglia visum lupum."

The worthy doctor seems to have been little aware that even at the date at which he wrote wolves still existed in the British Tslands. Dr. John Walker was almost as much at fault when he wrote: "Canis lupus. Habitavit olim in Britannia. Quondam incola sylva caledonice. In Scotia seculo av. extinctus, et postremo in regione Navernice." $†$

Pennant, referring to the received opinion that a great part of the kingdom was freed from Wolves through the exertions of King Edgar, says:- "In England he attempted to effect it by commuting the punishments for certain crimes into the acceptance of a number of Wolves' tongues from each criminal; in Wales by converting a tax of gold and silver into an annual tribute of 300 Wolves' heads. Notwithstanding his endeavours, however, and the assertions * "Joannis Caii Britanni 'de Canibus Britannieis.'” Liber unus. Londini, per Gulielmum Seresinm. Svo, 1570 . There is a translation of this work in the British Museum, entitled, "Of Englishe Dogges, newly drawn into English." By Abraham Fleming, Student. London. 4to, 1576. A reprint of this has been reeently published. † "Nammalia Scotica,' in "Essays on Nat. Hist. and Rural
Eeonomy," 1814, p. 480. 
of sume authors to the contrary, his scheme proved abortive."**

We have met with a statement to the effect that "two wooden Wolves' heads still remain near. Glastonbury on an ancient, house where [query, on the site of which] at Eadgerly, King Edgar lived and received annually his tax from the Welsh in 300 heads."'

'This statement, however, conflicts somewhat witl, that of Holinshed, who says that "the carcases heing" brought into Lloegres, were buried at Wolfpit in Cambridgeshire." †

In the Forest Laws of Canute, promulgated in Ior6, the Wolf is thus expressly mentioned:-_" As for foxes and wolves, they are neither reckoned as beasts of the forest or of venery, and therefore whoever kills any of them is out of all danger of forfeiture, or making any recompense or amends for the same. Nevertheless, the killing them within the limits of the forest is a breach of the royal chase, and therefore the offender shall yield a recompense for the same, though it be but easy and gentle."s

It was doubtless to this constitution that the Solicitor-General St. John referred, at the trial of the Earl of Strafford, when he said, "We give law to hares and deer, because they are beasts of chase; but we give no law to wolves and foxes, because they are

* "British Zoology," vol. i. p. 88 (18I2).

† "Sussex Archacol. Coll." vol. iv. p. 83 (1851).

¥ "Chronicles," vol. i. p. 378 (4to ed. I8o7).

$\S$ Sec Manwood's "Forest Laws." The Charter of the Forest of Canutus the Dane (\$27). 
beasts of prey, but knock them on the head wherever we find them."*

Liulphus, a dean of Whalley in the time of Canute, was celebrated as a wolf-hunter at Rossendale, Lancashire. ${ }^{\dagger}$

Matthew Paris, in his "Lives of the Abbots of St. Albans," mentions a grant of church lands by Abbot Leofstan (the I 2 th abbot of that monastery) to Thurnoth and others, in consideration of their keeping the woods between the Chiltern Hundreds and London free from wolves and other wild beasts.

It would seem that the "ancient and accustomed tribute" due to the English kings was repeated by the Welsh princes in the very last years of the Anglo-Saxon monarchy. It was demanded by and rendered to Harold.

Period from the Conquest to the reign of Henry VII. - Historical evidence of the existence of wolves in Great Britain before the Norman Conquest, as might be expected, is meagre and unsatisfactory, and the abundance of these animals in our islands prior to that date is chiefly to be inferred from the measures which in later times wert devised for their destruction.

In the "Carmen de Bello Hastingensi," by Guido, Bishop of Amiens (v. 57I), it is related that William the Conqueror left the dead bodies of the English upon the battle-field to be devoured by worms, wolves, birds, and dogs-vermibus, atque lupis, avibus, cani-

* Clarendon, "Hist. Reb." fol. ed., i. p. 183:

† Whitaker's "History of Whalley," p. 222.

† Palgrave.

K 2 
busque voranda. When Waltheof, the son of Siward, with an invading Dinish army arrived in the Humber, in September; r 069, and, reinforced by the men of Northumbria, made an attack upon York, it is related that 3,000 Normans fell. A hundred of the chiefest in rank were said to have fallen amongst the flames by the hand of Waltheof himself, and the Scalds of the North sang how the son of Siward gave the corpses of the Frenchmen as a choice banquet for the Wolves of Northumberland.**

In ro76 Robert de Umfraville, ${ }^{\dagger}$ Knight, lord of Toures and Tain, otherwise called "Robert with the Beard," being kinsman to that king, obtained from him a grant of the lordship, valley, and forest of Riddesdale, in the county of Northumberland, with all castles, manors, lands, woods, pastures, water's, pools, and royal franchises which were formerly possessed by Mildred, the son of Akman, late lord of Riddesdale, and which came to that king upon his conquest of England; to hold by the service of defending that part of the country for ever from enemies and Wolves, with the sword which King William had by his side when he entered Northumberland. $t$

I087-II00. The inveterate love of the chase

* Freeman's "Norman Conquest."

+ "The name seems to be derived from one of the several places in Normandy now called Amfreville, but in some instances originally, Omfreville, that is Humfiedi villa, the vill or abode of Humphrey." -Lower, Patronymica Britannica.

‡ See Dugdale's "Baronage," vol. i. p. 504; and Blount's "Ancient Tenures," p. 24 r. 
possessed by William Rufus, which prompted him to enforce, during his tragical reign, the most stringent and cruel forest laws, is too well known to readers of history to require comment. It cannot be doubted that in the vast forests* which then covered the greater part of the country, and through which he continuously hunted, he must have encountered and slain many a Wolf. Yet, strange to say, a careful search through a great number of volumes has resulted in a failure to discover any evidence upon this point, or indeed any mention of the Wolf in connection with this monarch.

Longstaffe, in his account of "Durham before the Conquest," states that a great increase of Wolves took place in Richmondshire during this century, and mentions incidentally that Richard Ingeniator dealing with property at Wolverston (called Olveston in the time of William Rufus) sealed the grant with an impression of a Wolf.

I roO-I 35 . In his passion for hunting wild animals, Henry I. excelled even his brother William, and not content with encountering and slaying those which, like the Wolf and the Wild-boar, were at that time indigenous to this country, he "cherished of set purpose sundrie kinds of wild beasts, as bears, libards, ounces, lions, at Woodstocke and one or two other places in England, which he walled about with

* "The word 'forest,' in its original and most extended sense, implicd a tract of land lying out (foras), that is, rejected, as of no value, in the first distribution of property."-WHITAKER, History of
Whalley, p. 193. 
larrd stone An. II20, and where he would ofters figlit with some one of them hand to hand." "**

Amongst other forest laws made in this reign, was one which provided that compensation should be made for any injury occasioned during a wolf hunt. Si quis arcu vel balista de subitanti, vel pedico ad lupos vel ad aliud capiendum posito, dampanum rel malum aliquod recipiat, solvat qui posuit. ${ }^{\dagger}$

I I 56. There can be no doubt that at this period, and for some time afterwards, the New Forest, as well as the Forest of Bere, in Hampshire, both favourite hunting-grounds with William Rufus and his brother: Henry, were the strongholds of the Wolf, as they were of the Wild-boar and the Red-deer, for in the second year of the reign of Henry II. the sheriff of Hants had an allowance made to him in the Exchequer for several sums by him disbursed for the livery of the King's wolf-hunters, hawkers, falconers, and others. "Et in liberatione luparionum roos. et in liberatione accipitrariorum et falconarionum. Regis 2 sli per Willelmum Cumin."’

In the fourth year of the same reign, the sheriffs of London were allowed by the Chancellor 40s. out of the Exchequer for the King's huntsmen and his dogs. "Et venatoribus Regis et canibus ejus $\mathrm{xl}^{s}$. per cancellarium."

Conan, Duke of Brittany and Earl of Richmond,

* Harrison's "Description of England," prefixed to Holinshed's "Chronicle," p. 226.

† "Leges Regis Henrici primi," cap. 90, § 2.

* Madox, "History and Antiquities of the Exchequer of the Kings of England from the Norman Conquest to the end of the Reign of lidward II.," vol. i. p. 204 (I769).

$\S$ Madox, tom. cit. p. 207. 
in 1164 , granted, amongst other privileges, to the Abbey of Jourvaulx, several pastures on the north side of the river Jore, reserving only liberty for his deer, likewise pasturage throughout his new forest, near Richmond, Yorkshire, for all their cattle, with power to keep hounds for chasing Wolves out of those their territories.*

It is related in the "Annales Cambriæ" (Harl. MSS., No. 3859 on vellum) that in I 166 a rabid Wolf at Caermarthen bit twenty-two persons, nearly all of whom died. $\dagger$

In I 67 , the Bishopric of Hereford was vested in the King in consequence of the see being then vacant; and in the account of John Cumin, who acted in the capacity of Custos, we find in the accounts of the revenue and expenditure of the temporalities a payment of ios. for three Wolves captured that year. "Et pro tribus Lupis capiendis, $x^{s . "}$

William Beriwere obtained from Henry II. the confirmation of all his lands, as also the forestership of the Forest of De la Bere, with power to take any person transgressing therein between the bars of Hampton and the gates of Winchester, and likewise between the river of Ramsey and the river of Winchester to the sea, as amply as his father had held the same in the times of King William and King Henry I. From Richard I. (whom he accompanied * Dugdale's "Baronage," vol, i. p. 48. "Ex. Regist. Archiep. Cant." p. $875 \%$.

$\dagger$ "Apud Kermerden lupus rabiosus duo de viginto homines momordit qui omnes fere protinus periercunt." T'his MS. is believed to be a translation from the original Welsh. Ed. Williams (M.aster of the Rolls Series), pp. 50, $5 \mathrm{I}$. 
to the Holy Land, and whom he was instrumental in delivering from prison when that king was confined in Germany) he obtained many valuable emoluments as well as large territorial grants, and in the following reign was no less fortunate with King John, who, having a great regard for him in consequence of his knowledge in the art and mystery of venery, gave him license to enclose his woods at Joare, Cadelegh, Raddon, Ailesberie, and Burgh Walter, with free liberty to hunt the hare, fox, cat, and Wolf, throughout all Devonshire, and likewise the goat beyond the precincts of the forest; and to have free warren throughout all his own lands for hares, pheasants, and partridges.*

From a charter of liberties granted by King John, when Earl of Morton, to the inhabitants of Devonshire, it appears that the Wolf was at that time included amongst the "beasts of venery" in that county. The original deed, which is still preserved in the custody of the Dean and Chapter of Exeter, is under seal, and provides inter alia as follows :-

"Quod habeant canes suos et alias libertates, sicut melius et liberius illas haberunt tempore ejusd. Henrici regis et reisellos suos, et quod capiant capreolum, vulpem, cattum, lupum, leporem, lutram, ubicumque illa invenirent extra regardum foresta mea." $\dagger$

I 209. Mr. Evelyn P. Shirley has printed $f$ two

* Dugdale's “Baronage," vol. i. p. 7or.

† Ex Autographo penes Dec. et Capit. Exon. From Bp. Lyttelton's Collection. Quoted by Pennant, "British Zoology," vol. ii. p. $30 S$.

+ "Collectanea 'Topographica et Genealogica," vol. vi. p. 299. 
deeds of the Ioth of John relating to the manor of Henwick, in the parish of Bulwick, county Northampton, held by the tenure of hunting the Wolf (fugaco'm lupi), and he suggests that from this tenure probably the family of Luvet or Lovett, originally of Rushton, and afterwards of Astwell, in the county of Northampton, bore, for their arms : Argent, three Wolves, passant, in pale, sable, armed and langued, gules.*

I 2 I 2. In this year, when the neighbourhood around Kingsclere was all forest, an entry occurs in the Patent Rolls of a payment of 5 s. as a reward for the capture of a Wolf at Freemantle. ${ }^{+}$The Roll referred to is doubtless the Rotulus Misce, annis Regis Johannis quartodecimi (I 2 I 2-I 2 I 3), where the following entries occur relating to the capture or chase of the Wolf:"On Thursday next in the octave of the Holy Trinity [May I 2], for a Wolf captured at Freemantle, [Surrey] by the dogs of Master Ernald de Auclent, 5s."

"Item. [at Hereford]. Thursday next following the Feast of St. Martin [Nov. 22] to Norman the keeper of the Veltrars, $\ddagger$ and to Wilkin Doggett, his associate, for two Wolves captured in the forest of Irwell, I o.s., by the king's command, \&c."

"Item. Wednesday next following the Feast of

* The Wolf frequently appears on heraldic beariugs.

† "Patent Rolls," May 31, 1212, quoted in "Sussex Archæological Collections," xxiv. p. I6I.

\$Veltrarius, or vautrarius, from the French vaultive, was a mongrel hound for the chase of the wild-boar. See Blount, "Ancient Tenures," p. 233 . 
St. Gregory [March I 2], for two Wolves captured, one at Boscha de Furchiis, the other at Willes, ios., given to Smalobbe and Wilck, the keepers of the veltrariõ of "Thomas de Sandford."

It is perhaps not generally known that the circumstince narrated in the story of Bedd Gêlert, with which every one is familiar, is said to have occurred in the reign of King John, and, as it is a story of a British Wolf, it is scarcely to be passed over here without some brief notice, the more so as it is not at all unlikely that it is founded on fact.

The tradition, as related by Bingley in his "Tour round North Wales,"* is to the effect that Llewellyn, who was Prince of Wales in the reign of King John, resided at the foot of Snowdon, and, amongst a number of other hounds which he possessed, had one of rare excellence which had been given to him by the king. On one occasion, during the absence of the family, a Wolf entered the house; and Llewellyn, who first returned, was met at the door by his favourite dog, who came out, covered with blood, to greet his master. The prince, alarmed, ran into the house, to find his child's cradle overturned, and the ground flowing with blood. In a moment of terror, imagining that the dog had killed the child, he plunged his sword into his body, and laid him dead on the spot. But, on turning up the cradle, he found his boy alive and sleeping by the side of the dead Wolf. This circumstance had such an effect on

* "A Tour round North Wales," I 8oo, vol. i. p. 363. See also Sir John Carr's "Stranger in Ireland," 4to, 1806. 
the mind of the prince, that he erected a tomb over the faithful dog's grave on the spot where afterwards the parish church was built, called from this incident Bedd Gêlert, or the grave of Gêlert. From this story was derived the common Welsh proverb, "I repent as much as the man who slew his greyhound."

The dog referred to belonged probably to the race called by Pennant "the Highland gre-hound," of great size and strength, deep-chested, and covered with long rough hair. This kind was much esteemed in former days, and was used for hunting by all the great chieftains in preference to any other. Boethius styles it "genus venaticum cum celerrimun tum audacissimum."

I 2 I6-I272. In the following reign of Henry III. Wolves were sufficiently numerous in some parts of the country to induce the king to make grants of land to various individuals upon the express condition of their taking measures to destroy these animals wherever they could be found.

In 1242 it appears that Vitalis Engaine made partition with William de Cantelupe, Baron of Bergavenny, of the manor of Badmundesfield, in Suffolk, as heir to William de Curtenai, and the same year had a summons, amongst divers great men, to attend the king, well appointed with horse and arms, in his expedition into France. He died in I 249, seized, inter alia, of part of the lordships of Laxton and Pichesle, in the county of Northampton, held by "petit serjeanty"-viz., to lunt the Wolf whensoever" the king should command.*

* Dugdale's "Baronage," vol. i. p. 466. 
Selden, in his notes to Drayton's "Polyolbion" (ix. 76), refers to the manor of P'iddlesey in Leicestershire, which was held by one Menry of Angage per serjeantiam capiendi lupos, and quotes as his authority "Itin. Leicesters. 27 Hen. III. in Archiv. Turx. Lond." In the same reign, William de Limeres held of the king, in capile, in the county of Soutlampton, one carucate* of land in Comelessend by the service of hunting the Wolf with the king's dogs. $\dagger^{-1}$

I272-1307. In the third year of the reign of Edward I., namely, in I275, Sir John d'Engayne, knight, and Elena d'Engayne, his wife, held lands in Pightesley, in the county of Nortiampton, by the service of hunting the Wolf, for his pleasure, in that county, $\ddagger$ from which it is to be inferred that this animal was then common enough to be hunted for sport, as the fox is now-a-days. Other lands in the same county were held at this time on condition of the tenant finding dogs "for the destruction of Wolves" and other animals. It appears by the Patent Rolls of the 9th year of Edward I. that in I 280, John Giffard of Brymmesfield or Brampfield, was empowered to destroy the Wolves in all the king's forests throughout the realm. \|

In I 28 I, Peter Corbet was commissioned to destroy

* Carucate, a plough land. As much arable land as one plough, with the animals that worked it, could cultivate in a year.

† Esc. temp. H. R. fil. R. Johannis. Harl. MS. Brit. Mus. No.7o8, p. S.

+ Plac. Coron. 3 Edw. I. Rot. 20, dorso. Blount, "Ancient Tcnures," p. 230.

§ Camden, "Britannia," p. 525, and Blount, p. 257.

II "Calend. Rot. Pat." 49. See also Rymer's "Fœdera," sub anno. 
all the Wolves he could find in the counties of Gloucester, Worcester, Hereford, Salop, and Stafford, and the bailiffs in the several counties were directed to be ready and assist him. The commission, which has been frequently referred to by different writers, runs as follows :-

\section{"Pro Petro Corbet, de lupis capiendis.}

"Rex, omnibus Ballivis, \&c. Sciatis quod injunximus delecto et fideli nostro Petro Corbet quod in omnibus forestis et parcis et aliis locis intra comitatus nostros Gloncester, Wygorn, Hereford, Salop, et Stafford, in quibus lupi poterunt inveniri, lupos cum hominibus canibus et ingeniis suis capiat et destruat modis omnibus quibus viderit expedire.

"Et ideo vobis mandamus quod idem intendentes et auxiliantes estis.

"Teste rege apud Westm. I4 Maii A.D. I 28 I."**

In the Wardrube Accounts of Edward I. preserved in the British Museum (Add. MS. No. 7966) anno 29 Edw. I. (I 30 I), the following entry occurs :-

"April 29. To the huntsman of Sir Peter Corbet, deceased, for bringing to the King the dogs which belonged to the said Peter at the time of his death. . . $6 s .8 d$.

In 1285 , William de Reynes held two carucatest of land at Boyton, in the parish of Finchingfield, in the county of Essex, by the serjeanty of keeping for the king five Wolf-dogs (canes luporarios). $\neq$ In the

* Rymer's "Fœdera," i. pt. 2, p. I92; ii. p. I68.

+ See note on last page.

+ Plac. Coron. I 3 Edw. I. Essex; Blount, "Ancient Tenures," p. 236. 
following year, John lingaine was returned as loolding one carucate of land in Great Gidding, in the county of Huntingdon, by the serjeanty of hunting the Wolf, fox, and wild cat, and driving away all vermin out of the forest of the king in that county.* About the sume time, Richard Engaine held one hundred shillings of land in the town of Guedding, in the county of Cambridge, by the serjeanty of taking Wolves, and he was to do this service daily (et facit servit suum cotidie), + from which it may be inferred that Wolves at this date were particularly troublesome. Indeed, it is recorded that during this reign in a certain park at Farley the deer were entirely destroyed by Wolves.

In I 297 John Engaine died, seized, inier alia, of certain lands in Pytesle, Northampton, found to be held of the king by the service of hunting the Wolf, fox [cat], badger [wild boar, and hare]; and likewise the manor of Great Gidding in com. Huntendon, held by the service of catching the hare, fox, cat, and Wolf within the counties of Huntendon, Northampton, Buckingliam, and Roteland. $\$$

In the accounts of Bolton Priory, quoted in Whitaker's "History of Craven" (p. 33I), occur entries in the years $1306-1307$, of payments made in

* "Plac. Coron. 4 Edw. T. Rot. 7," dorso ; Blount, 1. 230.

† "Testa de Nevil," p. 358; Blount, p. 262.

+ "Will. Poer fecit parcum apud Farley ct quod pater Comitis Gilberti de Clare comes Gloucestriæ dedit ei quasdam feras ad praxdictum parcum instaurandum, quæ feræ per lupos destrucbantur." $18 \mathrm{Edw}$. I. (1290) Wygorn. rot. 50 in abbreviat. Rotul.

$\S$ Dugdale's "Baronage," vol. i. j. 466 . Sce also the Rotuti IInndredorum, ii. p. 627. 
reward for the slaughter of Wolves, as "Cuidam qui occidit lupum," but the price paid to the slayer is not stated. Whitaker in a note to this remarks:"Wolves, therefore, though rare, were not extinct in Craven in the beginning of the fourteenth century. This is an important circumstance."

1307-I327. In the fourth year of Edward II. (I 3 II) a composition was made between Sir John de Mowbray, son and heir of Sir Roger de Mowbray, of the one part, and the Abbot of Selby of the other part, whereby the said Sir John quitclaimed and released to the abbot all his right in the soil and manor of Crowle and other places therein mentioned, and the abbot and convent granted to the said Sir John de Mowbray certain woods, saving their free warren of goats, foxes, Wolves, conies, \&c.*

'The king's forest of the Peak in Derbyshire was of great extent, and about this time was much infested with Wolves. A family of the hereditary name of Wolfhunt held lands by the service of keeping the forest clear of these destructive animals. From the records in the Tower of London ( $13 \mathrm{Edw}$. II.) it appears that in 1320 some persons held lands at Wormlill, in the county of Derby, by the service of hunting and taking Wolves, from whence they were called Wolfhunt or Wolvehunt.

Mr. W. H. G. Bagshawe, of Ford Hall, Chapel-en-

* Burton, "Monasticon Eboracense," p. 389. The Abbots of Selby and of St. Mary, at York, were the only two mitred abbots in Yorkshire.

† 'The Irocal Laws, Courts, and Customs of Derbyshire,' "Journ. Brit. Archaeol. Assoc." vol. vii. p. I97. 
le-Frith, Derbyshire, a descendant of the same family as Mr. F. W. Bagshawe, the present owner of Wormhill Hall, in reply to inquiries on the subject, has been good enough to write as follows:-

"With the particulars in Blount's 'Tenures" I have long been familiar, but I am sorry to say that I cannot add to them. Wormhill Hall was never, so far as I know, held under the tenure of destroying Wolves, but it is most probable that a portion of the lands there were originally held by the tenure of preserving the king's 'verte and venyson' in his forest of the Peak. There is a tradition that the last Wolf in England was killed at Wormhill, but I never saw any evidence of it, nor did I ever hear any date assigned. In my pedigree of our family I find a note to the effect that John de l'Hall (the ancestor of John de l'Hall, whose daughter Alice was the wife of Nicholas Bagshawe) was appointed a forester (of fee, I suppose) to the king by deed dated I 349." **

In 1321 William Michell, son and heir of John Michell, held a messuage and land at Middelton Lillebon, co. Wilts, of the king in capite, by the serjeanty of keeping his Wolf-dogs-per serjantiam custodiendi canes luparios Regis. $\dagger$

3 327-1 377. So far as can be gathered from history, it would seem that while stringent measures were being devised for the destruction of Wolves in all or must of the inhabited districts which they frequented,

* Camden, "Britannia," tit. Derbyshire, i. p. 591; Blount, "Ancient 'Tenures," p. 250.

† Luparios elsewhere tuporarios: Harl. MIS. Brit. Mus. No. I34, p. 8o. Blount, "Ancient 'L'enures," p. 258. 
in the less populous and more remote parts of the country, steps were taken by such of the principal landowners as were fond of hunting to secure their own participation in the sport of finding and killing them.

In Edward III.'s time, Conan, Duke of Brittany, in I 342, gave pasture for cattle through all his new forest at Richmond in Yorkshire to the inmates of the Abbey of Fors in Wensleydale, forbidding them to use any mastiffs to drive the Wolves from their pastures. *

In the same year, Alan, Earl of Brittany, gave them common of pasture through all his forest of "Wandesley-dale ;" and to cut as much grass for hay as they might have occasion for, and also gave them leave to take such materials out of the said forest to build their houses, and for other uses; and such iron and lead as the monks found they might apply to their own use; and if the monks or their servants found any flesh of wild beasts in the forest, killed by Wolves, they might take it to their own use. $\uparrow$

In I 348, we find that Alan, son and heir of Walter de Wulf hunte, paid a fine to the king of $2 s .4 d$. for his relief in respect of Jands at Mansfield Woodhouse in the county of Nottingham, which he held by the service of hunting Wolves out of the forest of Shirewood, if he should find any of them.t

* Escheat, i5 \& 16 Edw. III. No. 76, in Turr. Lond. See also Burton, "Monasticon Eboraeense," p. 370. The Abbey of Fors, in Wensleydale, was founded in I 145 (Whitaker).

$\dagger$ Burton, loc. cit.

$\mp$ De termino Trin. anno 2 I Edw. III. Rot. I. Harl. MI.S. Brit. Mus. No. 34, p. I66. Blount, "Aneient Tenures," p. 258. 
Thomas Engaine, dying without issue in I 368, was found to be seized of I 4 yardlands and meadow, and I 4 s. 4 d. rent, in Pightesle, in the county of Nortlampton, held by the service of finding, at his own proper costs, certain dogs for the destruction of Wolves, foxes, martens, aats, and other vermin within the counties of Northampton, Roteland, Oxford, Eșsex, and Buckingham.*

I 377-I 399. In Richard II.'s reign Wolves must have been common enough in the forests of Yorkshire, for in the account-rolls of Whitby Abbey, amongst the disbursements made between I 394 and I 396, we find the following entry of a payment for dressing Wolf skins:-

Pro tewyngt xiiij pellium luporum . . . . ro. ixd.

Doubtless the skins of animals killed in some great raid made upon them at the instigation of the Abbey.

I 399-I 4 13. In Henry IV.'s reign, Sir Thomas de Aylesbuxy, knight, and Catharine his wife, held of the king, in capite, the manor of Laxton, inter alia, with appurtenances in the county of Northampton, by "grand serjeanty"-viz., by the service of taking Wolves, foxes, wild cats, and other vermin in the counties of Northampton, Rutland, Oxford, Essex, Huntingdon, and Buckingham.

Shakespeare has pictured wolves as existing in Kent

* Rot. fin. 42 Edw. III. m. I3. Dugdale's "Baronage," rol. i. p. 467; and Blount, "Ancient T'enures," p. 231.

† To "tew," or "taw," an obsolete word signifying to beat and dress leather with alum. Nares, "Glossary."

\& Blount, op. cit. p. 260. 
in the time of Henry VI. When the Duke of Suffolk lands at night upon the shore near Dover, he hears

\section{"Loud howling wolves arouse the jades \\ That drag the tragic melincholy night."}

Second Part of Hienry VI., act iv. sc. I.

This may or may not be a poetic license. At all events, no evidence on the subject is now forthcoming, and we must turn, therefore, to some more reliable source of information.

I 422-I46I. In the eleventh year of Henry VI. (1433), Sir Robert Plumpton, Knight, was seized of one bovate of land in Mansfield Woodhouse, in the county of Nottingham, called Wolf-hunt land, held by the service of winding a horn and chasing or frightening the Wolves in the forest of Shirewood.* This tenure is particularly referred to by the Rev. Samuel Pegge in his Paper "On the Horn as a Charter or Instrument of Conveyance." $\dagger$ A coloured plate of an ancient horn of the kind referred to, in the possession of the late Lord Ribblesdale, will be found in Whitaker's "History and Antiquities of the Deanery of Craven" (I805), p. 34.

In the seventeenth year of the reign of Henry VI., namely, in I 439, Robert Umfraville, a descendant, no doubt, of the Robert de Umfraville mentioned in 1076, held the castle of Herbotell and manor of Otterburn, of the king, in capite, by the service of keeping the valley and liberty of Riddesdale,

* Escaet. i I Hen. VI. n. 5. Blount, p. 312.

$\dagger$ "Archæologia," vol. iii. p. 3. See also Thoroton, "Autiq. Nottingham," p, 273; and Strutt, "Sports and Pastimes," p. I9. 
where the said castle and manor are situated, free fiom Wolves and robbers."*

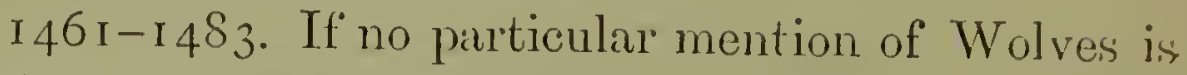
to be met with in the days of Edward IV., lis reign would nevertheless deserve notice here firom: the fact that at this period lived Juliana Barnes, or Berners, a lady of an ancient and illustrious house, who was commonly styled the Diana of her age, and who writ or compiled divers treatises on Hunting, Hawking, Fishing, and Heraldry. $\dagger$

In her "Book of St. Albans," written about I 48 I, and first printed in 1486 , she includes the Wolf amongst the beasts of venery, and thus instructs her readers on the subject :-

"Wheresoeure ye fare by fryth or by fell:

My dere chylde take hede how Tristram $\ddagger$ doo you tell, How many manere bestys of venery there were:

Lysten to your dame, and she shall you lere.

Foure maner bestys of venery there are:

The fyrste of theym is the harte, the seeonde is the hure,

The boore is one of tho: the wulfe and not one mo."

The old books on hunting state that the season for hunting the Wolf was between the 25 th of December and the 25th of March. This of course was only so long as Wolf-hunting was an amusement and a royal sport. As soon as it became a necessity, and a price was set on the animal's head, it was killed whenever and wherever it could be found.

I485-1509. Some time between these two dates,

* Madox, "Baronia Anglica," p. 244.

+ Longstaffe, "Memoirs of the Life of Ambrose Barmes" (Surtees Society), I 867, p. 27.

† Manwood, in his "Forest Iaws," mentions "Sir Tristram," an ancient forester, in his worthy treatise of lunting. 
during the reign of Henry VII., it is probable that the Wolf became finally extirpated in England, although for nearly two centuries later, as will presently appear, it continued to hold out against its persecutors in Scotland and Ireland. That it was rare if not quite extinct in England about this time, may be inferred from the circumstance that little or

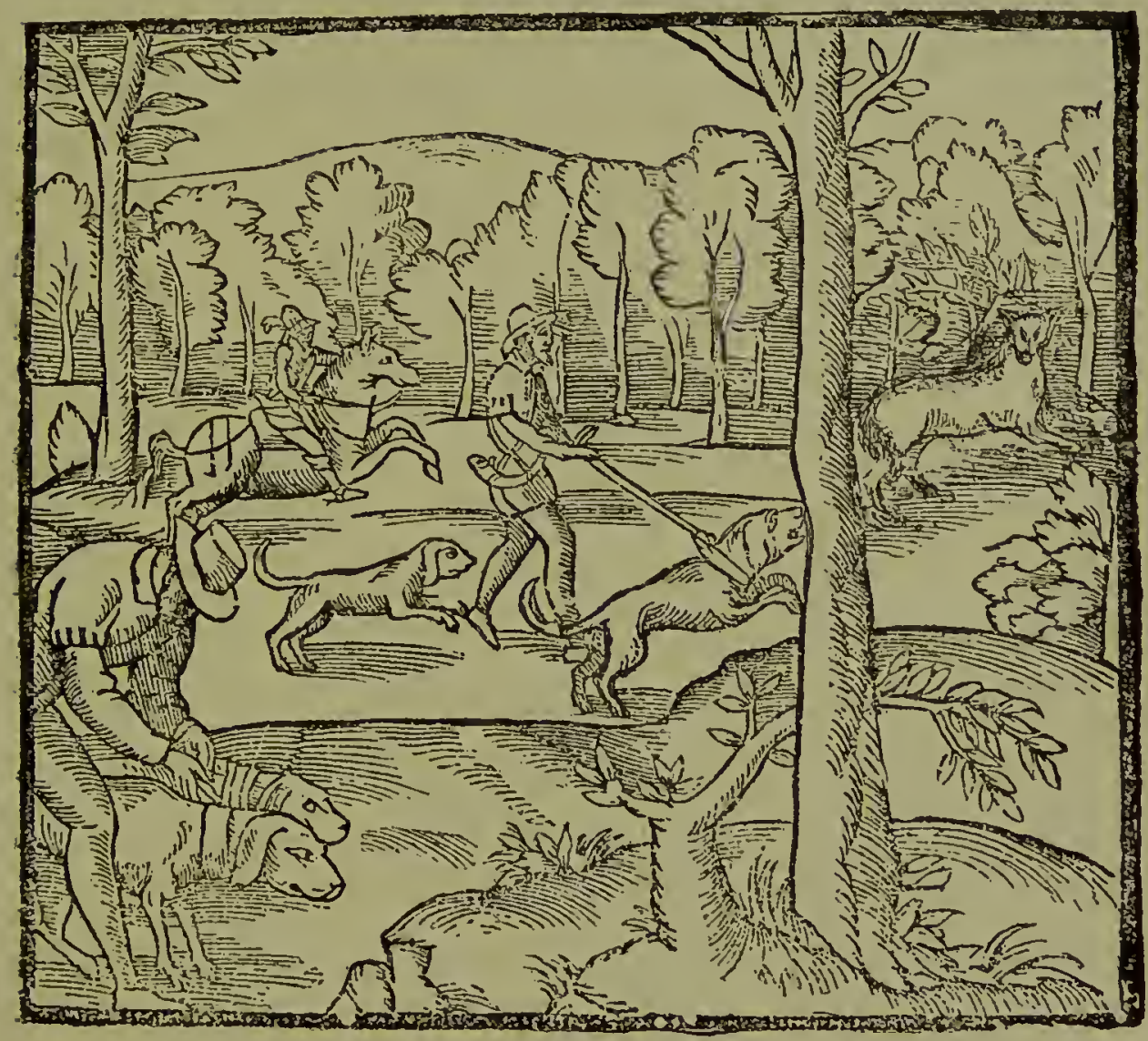

A WOLF-IIUNT. FROII AN ENGRATING OF THE SIXTEENTH CENTURY.

no mention is made of it either in this or any subsequent reign. It is true Professor Newton, in his "Zoology of Ancient Europe," has stated (p. 24) that the Wolf was found in the North of England in the reign of Henry VIII., a statement which has been also advanced, or copied, by other 
writers, * but we have not net with any proof of this. Indeed, Professor Newton has lately been good enough to inform: us that he has forgotten his authority for the statement, and thinks it possible a reference to the MS. of his essay, which was not preserved, would show that, by a typographical error, the numerals VIII. were printed for VII.

In Longstaffe's "Memoirs of the Life of Ambrose Barnes," + it is stated that "his immediate ancestors held an estate of $500 l$. a year of the Earls of Rutland and Belvoir, one of whom (a Barnes of Hatford near Barnard Castle) was commonly called Ambrose 'Roast wolf,' from the many wolves which he hunted down and destroyed in the time of Henry VII." $\ddagger$

In a footnote to this passage, the editor remarks that "the statement must be taken cum grano salis. Belvoir is not a title, and the Manners family did not become Earls of Rutland until 525, $_{5}$, in the reign of Henry VIII.\$ On the other hand, the period of VII. is late for wolves, although Richmondshire might well yield some of the latest specimens in England. Doubtless they were familiarly associated with wildness of country long after their extinction. Many a tradition would linger in the families of their' destroyers. Ambrose 'Roast Wolf' was probably a real person of some date or other."

*Wise's "New Forest, its History and its Scenery," p. I 4 .

$\dagger$ "Memoirs of the Life of $M_{r}$. Ambrose Barnes, late Merchant and sometime Alderman of Newcastle-upon-Tyne," p. 28. (Surtecs. Society, 1867.)

+ Sec also Longstaffe's "Durham before the Conquest," p. 49.

$\S$ It is possible that a typographical error may have been made here also, and that Ambrose "Roast IVolf " may have lived in the reign of Hemry VITI., net Henry VII. 
Within the precincts of Savernake Forest, the property of the Marquis of Ailesbury, near Marlborough, there is still existing a very old barn and part of a house, known as "Wolf Hall," or "Wulf-hall." It was the ancient residence of the Seymours, and when Henry VIII. married Lady Jane Seymour it was here that he came a-courting, here that he was married, and in this barn the wedding festivities are said to have taken place. In reply to an inquiry whether any tradition exists in the county to explain the name "Wolf Hall," the Rev. A. C. Smith, of Yatesbury Rectory, Calne, has obligingly written as follows:- "It is supposed to have had nothing to do with the animal 'Wolf,' but rather with 'Ulf,' the owner's name, if there was such a person, and in the Domesday record it is spelt 'Ulfhall.' the same time I must add that Leland in his Itinerary (ix. 36) calls it in Latin 'Lupinum villa splendida,' and again in his poem on the birth of the Prince of Wales, afterwards King Edward VI., Incoluit villam, quce nomine dicta lupinum.'† Bishop 'Turner also ("Bibl. Brit. Hibern.") speaks of certain epistles written by Edward, the future Protector, son of John Seymour, 'de Puteo Lupino, vulgo Wolfhall.' So I am not so certain that the derivation is not from the animal. At all events, it is quite clear that no place could be more fitted for Wolves than the wild extensive forest of Savemake hard by ; indeed, if Wolves existed at all in England now, that would be just the very harbour for them."

* See Wilts Archceological Magazine, June i 875, p. I43.

† "Genethliacon illustrissimi Eduardi Principis Cambria," 1543. 
Many names of places compounded with "Wolf" still remain to attest probably the former existence of this animal in the neighbourhood. Wolmer-i.e., Wolfmere or Wolvemere-is an instance of this. Wolferton is another. Besides these, we have Wolfscote, Derbyshire; Wolfhamcote, Warwickshire; Wolferlow, Hereford; Wolfs Castle, Pembroke; and Wolfpits, Radnorshire ; the last named very suggestive, as indicating probably a former burial-place for the carcases of Wolves brought in during the period of their persecution in Wales. In the parish of West Chiltington, near Pulborough, Sussex, on the south edge of the lower greensand formation which overlooks the Weald, is a spot called "Wolfscrag," where, tradition says, the last Wolf of the Weald was killed. Three fields in the neighbourhood still bear the respective names of Great Den, Little Den, and Far Den fields.

Wolfenden in Rossendale, and Wolfstones in Cliviger (Lancashire), both attest the existence of this animal there when those names were imposed.* Many other instances, no doubt, might be adduced. In the parish of Beckermont, Cumberland, is a small hill, commonly called "Wotobank." A traditionary story, of great antiquity, says that a lord of Beckermont and his lady and servants were one time hunting the Wolf; during the chase this lord missed his lady; after a long and painful search, they at last,

* Whitaker, "History of Whalley," i. p. 74. " "The first mentiou of Rossendale by name is in the memorable story of Liwlphus, Deau of Whalley, who, at a place called Ledmesgreve, cut off the tail of a Wolf in hunting" (tom. cit. p. 316.) 
to his inexpressible sorrow, found her body lying on this hill or bank, slain by a Wolf, and the ravenous beast in the very act of tearing it to pieces, till frightened by the dogs. In the first transports of his grief the first words that he uttered were, "Woe to this bank!" since which time it has been commonly called "Wotobank." *

In Lancashire, Dr. Whitaker particularly mentions the great forests of Blackburnshire and Bowland as "among the last retreats of the Wolf." +

The "wolds" of Yorkshire appear, from the dates of parish books, to have been infested with Wolves perhaps later than any other part of England.

"In the entries at Flixtın, Hackston, and Folkston, in the East Riding of Yorkshire," says Blaine, "are still to be seen memoranda of payments made for the destruction of Wolves at a certain rate per head. 'They used to breed in the 'cars' below, amongst the rushes, furze, and bogs, and in the night-time to come up from their dens; and, unless the sheep had been previously driven into the town, or the shepherds were indefatigably vigilant, great numbers were sure to be destroyed." +

Apparently, however, some error has been made in the orthography of the localities referred to. Flixton is in the parish of Folkton, near Scarbcro'. We can-

* Hutchinson, "Hist. and Antiq. Cumberland" ( 1794), vol. ii. p. I6. Upon this tradition was founded an "elegant elegiac tale" by Mrs. Cowley, which will be found prefixed to the second volume of the work quuted.

† Op cit. i. p. 205. The last herd of red deer was destroyed there in 1805 .

+ Blaine's "Encyclop. Rural Sports" (1858), p. 105. 
not find that there is any such place as "Hackston ;" but Staxton adjoins the other places named, and is in the parish of Willerby. 'The Vicar of Willerby, the Rev. G. Day, at our request most obligingly instituted a search, but could not succeed in finding any parish books of any kind to throw light on the subject. He writes: "There are no gentry resident in this parish, and the churchwardens have been tenantfarmers for generations. Of course great changes have occurred within the last, say, fifty years, amongst these tenant-farmers. Many names have altogether disappeared from the parish roll, and it is thought probable by some of the old farmers here that churchwardens in past days having left their farms and gone to other parishes took the parish books with them, and that these have either been destroyed or are lying hid in some descendant's lumber-room."

In a Paper "On Druidical Remains in the Parish of Halifax, Yorkshire," by the Rev. John Watson, M.A., F.S.A., " the author says that " in the township of Barkisland is a small ring of stones, now called $(177 \mathrm{I})$ by the name of the volf-fold. It is but a few yards in diameter, but the exact measurement of it I have lost or mislaid.

"The stones of which it consists are not erect, but lie in a confused heap like the ruins of a building. This place I took at first, from its name, to have been either a decoy for the taking of wolves, or a place to secure them in for the purpose of hunting; but observing that Mr. Borlase (p. I98) has attributed * "Archeologia," vol. ii. p. 355. 
some such little cirques to the Druids, I lave mentioned it here for the further examination of antiquaries, who are desired to take notice that if ever there was a wall here of any strength, the best stones must have been carried away; for what are left are extremely rude, and totally unfit of themselves to compose any sort of building; also that these few insignificant pebbles, as they now appear, must be of considerable antiquity, as well as once have been of considerable account, because they give the name of Ringstone Edge to a large tract of land around them."

The late Wm. Hamper, F.S.A., in some learned observations on certain ancient pillars of memorial called Hoar Stones ("Archæologia," xxv.), gives a list of such as were known to him, and, in particular, mentions (p. 53) the wolf-stone, a single merestone, one immense natural block on Dr. Whitaker's estate, which, in all probability, was erected to commemorate some notable slaughter of Wolves in days gone by.

The fur of the Wolf was formerly used for trimming robes, and was employed for this purpose at least as late as the time of Elizabeth. In a will rlated 1573 preserved in the Registry of the Prerogative Court of Canterbury the following clause occurs :-

"Also I give unto my son Tyble my sherte gown faced with Wolf and laid with Billement's lace; also I give unto my brother Cowper my other sherte gown faced with foxe; also I give unto Thomas Walker my night gown faced with coney, with one lace also, and my ready [ruddy] colored hose."

Where the testator procured the Wolf-skin it is of 
course impossible to siry, but it is noticeable that no foreign furs (such as sable, ermine, and lyux) are mentioned in his Will; the only furs disposed of besides Wolf being those of indigenous animals-the fox and the coney.

\section{Historical Evidence.-Scothand.}

In a preceding page it was incidentally remarked that the Wolf survived in Scotland to a much later date than was the case in England. The reason is pretty obvious. Long after the animal had been extirpated in England the condition of the country in North Britain remained eminently suited to its nature. Vast tracts of forest and moor, rugged and well-nigh impenetrable in parts, entire districts of unreclaimed and uncultivated land, the absence of roads, and the consequent difficulty of communication between scattered and thinly populated hamlets, long contributed to shelter the Wolf not only from final extinction but from the incessant persecution which had driven it from the south.

The aspect of the country in Scotland at the date to which we refer may be imagined from a remark of John Taylor, the Water Poet, who in i6 I 8 travelled on foot from London to Edinburgh. When visiting Braemar, he says, "I was the space of twelve days before I saw either house, cornfield, or habitation of any creature, but deer, wild horses, Wolves, and such like creatures, which made me doubt that I should never have seen a house again."

It must not be supposed, however, that the Wolf 
at any time lived unmolested in Scotland. As the herdsman's foe, it was always regarded as a beast to be pursued and killed whenever and wherever practicable, and from the earliest times the chase of the Wolf was considered by kings and nobles to be one of the most exciting and enjoyable of fieldsports.

We learn from Holinshed that Dorvadil, the fourth King of the Scots, "set all his pleasure on hunting" and keeping of houndes and greyhoundes, ordayning that every householder should find him two houndes and one greyhounde. If a hunter chanced in following the game to lose an eye or a limme, so that he were not able to helpe himselfe after that time, he made a statute that he should be founde of the common treasury. He that killed a Wolf should have an oxe for his paines. This beast, indeed, the Scottish men even from the beginning used to pursue in al they might devise, because the same is suche an enemie to cattayle, wherein consisted the chiefest portion of all their wealth and substance."**

Of a later king, Ederus, we are told that his "chiefe delighte was altogyther in liunting and keeping of houndes and greyhoundes, to chase and pursue wild beastes, and namely the Woolfe the herdsman's foe, by means whereof his advancement was muche the more acceptable amongst the nobles, who in those dayes were whollye given to that kynde of pleasure and pastyme." +

* Holinshed's "Chronicles of Scotland," I 577, p. I 3.

† Holinshed, tom. cit. p. 27 
Ferquhard II., who died A.D. 668, is said to have proved so bad a king that Colman, Bishop of Lindisfarne, declured the vengeance of God would overtake him. "And sure his wordes proved true ; for within a moneth after, as the same Ferquhard followed in chase of a Wolfe, the beast being enraged by pursuite of the houndes, flew back uppon the king, and snatching at him, did wounde and byte him righte sore in one of his sides, immediately whereupon, whether through anguishe of his hurt, or by some other occasion, he fell into a most filthie disease." "**

The sport enjoyed in Scotland in former days must have been incomparable. Bellenden, the translator of Hector Boece, says, that in the forests of Caledonia there were "gret plente of haris, hartis, hindis, dayis, rais, Wolffis, wild hors, and toadis," (foxes), and he particularly mentions "the Wolffis" as being "rycht noysum to the tame bestiall in all partis of Scotland."

In the reign of Malcolm IV. (I I 53-1 I65) Robert de Avenel granted to the monks of Melrose the right of pasturage in his lands in Eskdale, reserving to himself the privileges of the feudal baron, to pursue the wild boar, the deer, and the stag. One of his successors questioned several of the claims to which the grantees considered ihemselves entitled, and it was ultimately decided in 1235 , in presence of King Alexander II., that they had no right to hunt over the lands in question, and were restricted from setting 
traps, excepting for Wolves.* It seems that, in order to protect their flocks, the monks of Melrose were in the habit of setting traps for Wolves as early as the reign of William the Lion ( I $165-$ I 2 I 4 ). + Wolfclyde, a part of the barony of Culter, in Lanarkshire, passed by grant to the Abbey of Melrose in I 43 r.f

In a grant of Alexander II. (I $14-1249$ ) to the monks of Melrose, in Ettrick Forest, mention is made of "Wulfhope," a name still familiar in the south of Roxburghshire. $\$$

In 1283, there was an allowance made for "one hunter of Wolves" at Stirling:\|

In 1427 , in the reign of James I. of Scotland, an Act was passed for the destruction of wolves in that kingdom. Further Acts with the like object were passed in 1457 , in 1525 , and in 1577 . The Act of I 525, however, is merely a modernized version of the law of 1427 , which is referred to in the statute of 1577 as "the auld act made tharon."

The law required " that ilk baron within his barony in gangand time of the year sall chase and seek the quhelpes of Wolves and gar slay them. And the baron sall give to the man that slays the Woolfe in his barony and brings the baron the head, twa shillings. And when the baron ordains to hunt and chase the Woolfe, the tenants sall rise with the baron. And that the barons hunt in their baronies and chase the

* Morton's "Monastic Annals of Teviotdale," pp. 273, 274.

† Chalmers" "Caledonia," ii. p. I32. Chart. Mel. 9r.

‡ Morton, op. cit. p. 276 .

$\S$ Chalmers" "Caledonia," ii. p. I 32.

II Innes" "Scotland in the Middle Ages;" p. I25. 
Woolfes four times a year, and als oft as onie Woolfe beis seen within the barony. And that na man seek the Woolfe with schott, but allanerly in the time of hunting them." The duty of summoning the people for a Wolf-hunt devolved upon the "schireffs" or" "bailyis," three times a year, between St. Mark's Day (April 2.5th) and Lammas (August ist), for, as the Act states, "that is the tyme of their quhelpes." The penalty for disregarding this summons was "ane wedder," "quhatever he be that rysse not." On the other hand, it was enacted that whoever slew a Wolf "sall haif of ilk householder of that parochin that the Woolfe is slayne within, a penny."

The Act of James II.'s time (I457), provided that "they that slayis ane Woolfe sall bring the head to the schireffe, baillie, or baronne, and he sall be debtour to the slayer for the summe foresaide. And quhatsumever hee bee that slayis ane Woolfe, and bringis the head to the schireffe, lord, baillie, or baronne, he sall have sex pennyes."

In some active instances, the exertion of these statutes might have cleared local districts, and a remarkable example of success was given by a woman -Lady Margaret Lyon, Baroness to Hugh third Lord Lovat. This lady having been brought up in the low country, at a distance from the Wolves, was probably the more affected by their neighbourhood, and caused them to be so vigorously pursued in the

* "Laws of the Parliament of Scotland," folio, I7SI, pp. IS, I9. See also Glendook's Scots Acts, 7 James I. c. I04, and I4 James II. c. 88 . 
Aird, that they were exterminated out of their principal hold in that range. According to the Wardlaw MS., "she was a stout bold woman, a great huntress; she would have travelled in our hills a-foot, and perhaps outwearied good footmen. She purged Mount Caplach of the Wolves." Mount Caplach is the highest range of the Aird running parallel to the Beauly Frith, behind Moniach and Lentron. Though the place of the lady's seat is now forgotten, its existence is still remembered, and said to have been at a pass where she sat when the woods were driven for the Wolves, not only to see them killed, but to shoot at them with her own arrows. The period of her repression of the Wolves is indicated by the succession of her husband to the lordship of Lovat, which was in 1450 , and it is therefore probable that the "purging" of Mount Caplach was begun soon after that date.*

Such partial expulsions, however, had little effect upon the general "herd" of Wolves, which, fostered by the great Highland forests, increased at intervals to an alarming extent. During the reign of James IV. (I488-I5I3), rewards continued to be paid for the slaughter of Wolves in Scotland, and we learn the value of a Wolf's head in those days from the accounts of the Lord High Treasurer.t For in-

* MIS. History of the Frasers, in the library of Lord Lovat (p. 44). Also the curious account of the Nortl Highlands called the Wardlaw MS. in the possession of Mr. Thompson, Inverness (p. 67).

+ Extracts from these accounts will be found in Pitcairn's " Criminal Trials in Scotland," vol. i. p. I 16. 
stance, under date "Octuber 24th, I 49I," we find this entry:-

"Item, til a fullow brocht ye king ij wolfis in Lythgow . . . Vs."

In the time of James $\mathrm{V}$. their numbers and ravages were formidable. At that period great part of Ross, Inverness, almost the whole of Cromarty, and large tracts of Perth and Argyleshire, were covered with forests of pine, birch, and oak, the remains of which continued to our time in Braemar, Invercauld, Rothiemurchus, Arisaig, the banks of Loch Ness, Glen Strath-Farar, and Glen Garrie; and it is known from history and tradition that the braes of Moray, Nairn, and Glen Urcha, the glens of Lochaber, and Loch Erroch, the moors of Rannach, and the hills of Ardgour were covered in the same manner.* All these clouds of forests were more or less frequented by Wolves. Boethius mentions their numbers and devastation in his time; $\dagger$ and in various districts where they last remained, the traditions of their haunts are still familiarly remembered. Loch Sloigh and Strath Earn are still celebrated for their resort, and in 1848 there were living in Lochaber old people who related. from their predecessors, that, when all the country from the Lochie to Loch Erroch was covered by a continuous pine forest, the eastern tracts upon the Blackwater and the wild wilderness stretching towards Rannach were so dense and

* MacFarlane's Geographical Collections. 'MS. Bibl. Facult. Jurid. ii. 192. Quoted in Stuart's "Lays of the Deer Forest."

+ "Scot. Hist." fol. 7. 
infested by the rabid droves, that they were almost impassable.*

In 1528 the Earl of Athole entertained the king, James V., with a great hunt which lasted three days. "It is said, at this tyme, in Atholl and Stratherdaill boundis, thair was slaine threttie scoir of hart and hynd, with other small beasties, sich as roe and roebuck, Woulff, fox, and wild cattis." +

A story is told of one John Eldar, a clergyman of Caithness, who on the death of James V. journeyed to England to present to Henry VIII. a project for the union of the two kingdoms. Being asked to explain the meaning of the name "redshanks," at that time given to the Highlanders, he said, "They "call us in Scotland, 'redshanks,' please it your Majesty to understand, that we of all people can tolerate, suffer, and away best with cold: for both summer and winter (except when the frost is nost vehement) going always bare-legged and bare-footed, our delight and pleasure is in hunting of red deer, Wolves, foxes, and graies [badgers] whereof we abound and have great plenty. Therefore, in so much as we use and delight so to go always, the tender, delicate gentlemen of Scotland call us 'redshanks." $\ddagger$

Harrison, who wrote in Elizabeth's time, says that though the English "may safelie boast of their" securitie in respect to wild animals, yet cannot the Scots do the like in everie point within their king-

* Stuart's "Lays of the Deer Forest," vol. ii. pp. 231, 232.

+ Robert Lindsay, "Chronicles of Scotland," ii. p. 346.

\pm Pinkerton's "History of Scotland," ii. p. 396. 
dome, sith they have greevous Woolfes and cruell foxes, beside some other of like disposition continuallie conversant among them, to the general hindrance of their husbandmen and no small damage unto the inhabiters of those quarters." *

William Barclay, who was a native of Aberdeenshire, and spent the early part of his life at the Court of Queen Mary, accompanied her Majesty on an excursion to the Highlands, and has left a curious account $\dagger$ of a royal hunt at which he was present, and which was organized for the Queen by John, fourth Earl of Athole, in I 563. Two thousand Highlanders were employed to drive all the deer from the woods and hills of Athole, Badenach, Mar, Moray, and the surrounding country. After mentioning incidentally that the Queen ordered one of the fiercest dogs to be slipped at a Wolf-" Laxatus enim regince jussu, atque immissus in lupum, insignis admodum ac ferox canis "- Barclay concludes his account of the "drive" with the statement that there were killed that very day 360 deer, 5 Wolves, and some roes.

According to Holinshed, Wolves were very destructive to the flocks in Scotland during the reign of James VI. in 1577. At this time they were so numerous throughout the greater part of the Highlands, that in the winter it was necessary to provide houses, or "spittals" as they were termed, to afford

* Harrison's "Description of England," prefixed to Holinshed's "Chronicles," i. p. 378.

† "De Regno et regali Potestate," \&c., 4to, 1600, p. 279. 
lodgings to travellers who might be overtaken by night where there was no place of shelter. Hence the origin of the Spittal of Glen Shae, and similar appellations in other places.

Camden, whose "Britannia" was published in I 586 , asserts that Wolves at that date were common in many parts of Scotland, and particularly refers to Strathnavern.

"The county," he says, "hath little cause to brag of its fertility. By reason of the sharpness of the air it is very thinly inhabited, and thereupon extremely infested with the fiercest of Wolves, which, to the great damage of the county, not only furiously set upon cattle, but even upon the owners themselves, to the manifest danger of their lives. In so much that not only in this, but in many other parts of Scotland, the sheriffs and respective inhabitants are bound by Act of Parliament, in their several sheriffdoms, to go a hunting thrice every year to destroy the Wolves and their whelps."*

Bishop Lesley, writing towards the close of the sixteenth century, complains much of the prevalence of Wolves at that period, and of their ferocity. $†$

"About this time there was nothing but the petty flock of sheep, or herd of a few milk-cows, grazed round the farm-house, and folded nightly for fear of the Wolf, or more cunning depredators." $\neq$

* Camden, "Britannia," vol. ii. p. 1279. Bishop Gibson, in his edition, has a marginal note to this passage- "No Wolves now in Scot:and" (1772).

† "De Origine, Moribus et Rebus Scotorum."

+ Irvine's "Scotch Legal Antiquities," p. 264. 
Towards the end of the sixteenth and beginning of the seventeenth centuries large tracts of forests in the Highlands were purposely cut down or burned, as the only means of expelling the Wolves which there abounded.

"These hills and giens and wooded wilds can tell How many wolves and boars and deer then fell."

Campbetl's Grampians Desolate, p. 102.

"On the south side of Beann Nevis, a large pine forest, which extended from the western braes of Locliaber to the Black Water and the mosses of Rannach, was burned to expel the Wolves. In the neighbourhood of Loch Sloi, a tract of woods nearly twenty miles in extent was consumed for the same purpose." *

John Taylor, the Water Poet, who made his "Pennyles Pilgrimage" into Scotland in 16 1 8, saw Wolves in Braemar. He writes: "My good Lord of Mar having put me into shape, I rode with him from his house, where I saw the ruins of an old castle, called the castle of Kindroghit. It was built by King Malcolm Canmore (for a hunting-house), who reigned in Scotland when Edward the Confessor, Harold, and Norman William reigned in England. I speak of it because it was the last house that I saw in those parts; for I was the space of twelve days after before I saw either house, cornfield, or habitation of any creature, but deer, wild horses, Wolves,

* Notes to Sobieski Stuart's "Last Deer of Beaun Doran." Sce his "Poems" published in I 822 under the assumed name of James Hay Allan. 
and such-like creatures, which made me doubt that I should never have seen a house again."**

Years later, as we learn from Sir Robert Gordon, the Wolf was still included amongst the wild animals of Sutherlandshire. He says the forests and "schases" in that county were "verie profitable for feiding of bestiall, and delectable for hunting, being full of reid deer and roes, Woulffs, foxes, wyld catts, brocks, skuyrells, whittrets, weasels, otters, martrixes, hares, and fumarts." $\dagger$

In 162 I the price paid in Sutherlandshire for the killing of one Wolf according to statute was 6l. $13 s .4 d$.

Wolf-skins are mentioned in r66I in a Customs Roll of Charles II., $\ddagger$ whence it appears that two ounces of silver were paid "for ilk two daker."

Twenty years later, if we are to credit the statement of Sir Robert Sibbald, whose "Scotia Illustrata" was published in 1684 , the animal had become extinct. His words are: Lupi olim frequentes erant, quidam etiam de Caledoniis ursis loquuntur.

* "The Pennyles Pilgrimage, or the Moneylesse Perambulation of John Taylor, alias the King's Majesties Water Poet. How he travailed on foot from London to Edenborough in Scotland. With his description of his entertainment in all places of his journey and a true report of the unmatchable hunting in the Brea of Marre and Badenoch in Scotland." 4to, Loudon, I68 I.

$\uparrow$ "Gencalogical History of the Earldom of Sutherland, from its origin to the year $1630 . "$

+ See Glendook's "Scots Acts," Charles II., p. 36.

$\S$ The word "daker" or" "dicker" (Greek $\delta \varepsilon k a$, ten) is still in use in the leather trade, and means a roll of ten skins. It was anciently spelt "dyker" or "dykker," and the market-toll was a penny each "dylinr." See the Durham Household Book, I530-1 534, pp. 107, 205, where this word frequently occurs. 
Sed horim genus deletum el ex insulâ exlerminatum.
est."**.*

Pennant states that the Wolf became extinct in Scotland in I680, when the last of the race was slain by Sir Ewen Cameron of Lochiel.t He adds that he had travelled "into almost every corner of that country, but could not learn that there remained even the memory of these animals among the oldest people."

From more recent investigation, however, it is clear that Sir Robert Sibbald and Pennant were both mistaken, for not only were Wolves slain in Scotland subsequently to r680, but numerous. traditions concerning these animals survived in the country to at least as recent a date as I 848 .

Traditions.-In a Gaelic forest lay "of a remote period, the date and author of which are uncertain," the Wolf is thus referred to as inhabiting the ancient pine woods of Scotland:

"Chì mì Sgòrr-eild' air bruaich a' ghlinn"

An goir a' chuthag gu-bìn an dòs.

'Us gòrm mheall-àild' nam mìle guibhas

Nan lìb, nan earba, 's nan lon."

"I see the ridge of hinds, the steep of the slopirg glen

The wood of cuckoos at its foot,

The blue height of a thousand pines,

Of wolves, and roes, and elks.§

* "Scotia Illustrata, sive Prodromus Historiæ Naturalis," folio, 1684, pars ii. p. 9.

$\uparrow$ Surtees gives the date of the death of the last Wolf in Scotland as. 1682. "History and Antiquities of the County of Durham,"vol. ii. p. 172.

\$ "British Zoology," vol. i. p. 88; and "Tour in Scotland," vol. i. p. 206.

§ From 'The Aged Bard's Wish,' given in Stuart's "Lays of theDeer Forest," ii. p. 9. 
Other Gaelic names for the Wolf are madadh alluidh, commonly used; faol chu, and alla mhadadh, all of which are composed of an epithet and a word which now means dog:* It is also called faol and mac tire, "earth's son." +

In Scrope's "Days of Deer-Stalking" (p. 109) is related an adventure with a Wolf that happened to Macpherson of Braekaely, when he had charge of the forest of Benalder, and was furnished to the author by Cluny Macpherson, chief of Clanchattan.

"He sallied forth one morning, as he was wont, in quest of venison, accompanied by his servant. In the course of their travel, they found a Wolf den-a Wolf being at that time by no means a rarity in the forest. Macpherson asked his servant whether he would prefer going into the den to destroy the cubs, or remaining outside to guard against the approach of the old ones. The servant, preferring what appeared to be an uncertain to a certain danger, said he would remain without; but here Sandy had miscalculated, for, to his great dismay, the dam came raging to the mouth of the cave, which no sooner did he see than he took to his heels incontinently, without even warning his master of the danger. Macpherson, however, being an active, resolute man, and expert at his weapors, succeeded in killing the old Wolf as well as the cubs."

This Macpherson of Braekaely was commonly p. 85 .

* Pinkerton's "Enquiry into the Early History of Scotland," vol. ii.

t Campbell's "Tales of the West Highlands," vol. i. p. 274. 
called Callum Beg; or little Malcolm; and there is reason to believe that he was one of those whu, fought in the famous battle of the Inch of Perth in the reign of Robert IIT. (1 390-I 406.)

In the districts where Wolves last abounded, says Stuart in the "Tays of the Deer Forest," miny traditions of their history and haunts have descended to our time. The greatest number preserved in one circle were in the neighbourhood of Strath Earn.

At Inver-Rua, on the Spean, and consequent]y within the lands of Keppach, there lived a Campbell of the Slioched Chailein Mhic-Dhomnacha, or Glen Urcha race. Although thus a tenant of one of the principal branches of the Clan Donald, and removed to the distance of forty miles from his cean tighe, he continued to pay his "calps" to his blood chief, the Knight of Loch Awe. This tax was a heifer, which was paid annually, and it happened one year that a short time before it fell due, the becst was killed on her pasture and half eaten by a Wolf. Campbell left what remained to tempt his return, and on the following night, watching the carcase, he shot the Wolf from behind a stone. Not being able, howerer, to afford another "calp," he flayed the dead heifer", and sent the torn hide to MacChailein MhicDonnacha, with a message that it was all which he had to show for his "calp;" upon which the chief observed, that he had sent sufficient parchment to write his discharge.

This is said to have happened in the time of Sir Duncan Campbell, called "Donacha dubh a' Cur- 
raclid," "Black Duncan of the Hood," so called from having been the last person of his rank who bore the old Highland hood in Argyllshire, and who lived in the reign of James VI. (1 $567-1603$ ).

Several traditions relative to Wolves are evidences of the accuracy with which oral relations have been transmitted through many generations, which is exemplified by the familiarity and fidelity with which they retain allusions to objects and customs disused for two hundred years.

An example of this occurs in an account of the slaughter of a remarkable Wolf killed by one of the lairds of Chisholm in Gleann Chon-fliadh, or the Wolves' Glen, a noted retreat of these animals in the sixteenth century.

The animal in question had made her den in a "càrn," or pile of loose rocks, whence she made excursions in every direction until she became the terror of the country. At length the season of her cubs increasing her ferocity, and having killed some of the neighbouring people, she attracted the enterprise of the Laird of Chisholm and his brother, then two gallant young hunters, and they resolved to attempt her destruction. For this they set off alone from Strath Glass, and having tracked her to her den, discovered by her traces that she was abroad; but detecting the little pattering feet of the cubs in the sand about the mouth of the den, the elder crept into the chasm with his drawn dirk, and began the work of vengeance on the litter. While he was thus occupied, the Wolf returned, and infu- 
riated by the expining yelps of her cubs, rushed at the entrance, regardless of the younger Chisholm, who made a stroke at her with his spear, but such was her velocity, that he missed her as she darted past, and broke the point of his weapon. His brother, however, met the animal as she entered, and being armed with the left-handed lamhainn chruaidh, or steel gauntlet, much used by the Highlanders and Irish, as the Wolf rushed open-mouthed upon him, he thrust the iron fist into her jaws, and stabbed her in the breast with his dirk, while his brother, striking at her flank with the broken spear, after a desperate struggle she was drawn out dead.

The spear and the left-handed gauntlet referred to in this tradition are arms mentioned by Spencer, Leslie, and other authorities, as characteristic of the Highlanders and Irish in the days of Queen Mary.*

It is true they retained the use of such weapons as late as their muster called the "Highland Host" in I678.t But no such remains appeared at Cilliechranchie, and it is therefore probable that the story has descended from the time of Charles II.

Another story is on record of a Wolf killed by a woman of Cre-lebhan, near Strui, on the north side of Strath Glass. She had gone to Strui a little before Christmas to borrow a girdle (a thick circular plate of iron, with an iron loop handle at one side for lifting, and used for baking bread). Having procured it,

* See Spencer's "Views of Ireland;" Derrick's "Image of Ireland;" Leslie, "De Origine, Moribus et Rebus Scotorum ;" and a print in the Douce Collection, Bodl. Lib. G. vi. 47.

t Wodrow MS. Bibl. Facult. Jurid., xcix. No. 29. 
and being on her way home, she sat down upon an old càrn to rest and gossip With a neighbour, when suddenly a scraping of stones and rustling of dead leaves were heard, and the head of a Wolf protruded from a crevice at her side. Instead of fleeing in alarm, however, "she dealt him such a blow on the skull with the full swing of her iron discus, that it brained him on the stone which served for his emerging head."

This tradition was probably one of the latest in the district, and seems to have belonged to a period when the Wolves were near their end. Their last great outbreak in the time of Queen Mary led to more vigorous measures, which in the time of Charles II. reduced their ranks to so small a number that in some districts their extinction is believed to have followed soon after that period. Thus, in Lochaber, the last in that part of the country is said to have been killed by Sir Ewen Cameron in r68o, which Pennant misunderstood to have been the last of the species in Scotland.*

Some traditionary notices there are of the destruction of the last Wolves seen in Sutherlandshire, consisting of four old ones and some whelps which were killed about the same time at three different places, - at Auchumore in Assynt, in Halladale, and in Glen Loth-widely distant from each other, and as late as between the years 1690 and 1700 .

The death of the last Wolf and her cubs on the

* In the Sale Catalogue of the "London Museum" which was disposed of by auction in April, 1818, there is the following cntry: "Lot 832. Wolf-a noble animal in a large glass case. The last Wolf killed in Scotland by Sir E. Cameron." 
eastern coast of Sutherlandshire, says Scrope, was attended with remarkable circumstances.

"A man named Polson, of Wester Helmsdale, accompanied by two lads, one of them his son and the other an active herdboy, tracked a Wolf to a rocky mountain gully which forms the channel of the Burn of Sledale in Glen Loth. Here he discovered at narrow fissure in the midst of large fragments of rock, which led apparently to a larger opening or cavern below, which the Wolf might use as his den. The two lads contrived to squeeze themselves through the fissure to examine the interior, whilst Polson kept guard on the outside.

: The boys descended through the narrow passage into a small cavern, which was evidently a Wolf's den, for the ground was covered with bones and horns of auimals, feathers, and eggshells, and the dark space was somewhat enlivened by five or six active Wolf cubs. Polson desired them to destroy these; and soon after he heard their feeble howling: Almost at the same time, to his great horror, he saw approaching him a full-grown Wolf, evidently the dam, raging furiously at the cries of her young. As she attempted to leap down, at one bound Polson instinctively threw himself forward and succeeded in catching a firm hold of the animal's long and bushy tail, just as the forepart of her body was within the narrow entrance of the cavern. He had unluckily placed his gun against a rock when aiding the boys in their descent, and could not now reach it. Without apprising the lads below of their irnminent peril, the stout hunter kept 
in firm grip of the Wolf's tail, which he wound round his left arm, and although the maddened brute scrambled and twisted and strove with all her might to force herself down to the rescue of her cubs, Polson was just able with the exertion of all his strength to keep her from going forward. In the midst of this singular struggle, which passed in silence, his son within the cave, finding the light exclucled from above, asked in Gaelic, 'Father, what is keeping the light from us?' 'If the root of the tail breaks,' replied he, 'you will soon know that.' Before long, hgwever, the man contrived to get hold of his huntingknife, and stabbed the Wolf in the most vital parts he could reach. The enraged animal now attempted to turn and face her foe, but the hole was too narrow to allow of this; and when Polson saw his danger he squeezed her forward, keeping her jammed in whilst he repeated his stabs as rapidly as he could, until the animal being mortally wounded, was easily dragged back and finished.

"These were the last Wolves killed in Sutherland, and the den was between Craig-Rhadich and CraigVoakie, by the narrow Glen of Loth, a place replete with objects connected with traditionary legends."

This story was related by the Duke of Sutherland's head forester in I 848 to Mr. J. F. Campbell, who has narrated it in his "Popular Tales of the West Highlands," vol. i. p. 273.

"Every district," says Stuart in his "Lays of the Deer Forest," "has its "last' Wolf," and there were * Scrope's "Days of Deer Stalking," p. 374. 
probably several which were later than that killed by Sir Ewen Cameron.* "The "last" of Strath Glass was killed at Gusachan according to tradition "at no very distant period." The "last" in Glen Urchard on the east side of the valley between Loch Leiter and Shengly, at a place called ever since Slochd it mhadaidh-i.e., the Wolf's den; and the last of the Findhorn and also (as there seems every reason to believe) the last of the species in Scotland, at a place between Fi-Giuthas and Pall-ì-chrocain, and according to popular chronology no longer ago than the year 1743. The district in which he was killed was well calculated to have given harbour to the last of a savage race. All the country round his haunt was an extent of wild and desolate moorland hills, beyond which, in the west, there was retreat to the vast wilderness of the Monaidh-laith, an immense tract of desert mountains utterly uninhabited, and unfrequented except by summer herds and herdsmen, but, when the cattle had retired, abundantly replenished with deer and other game, to give ample provision to the "wild dogs." The last of their race was killed by MacQueen of Pall-à-chrocain, who died in the year I797, and was the most celebrated "carnach" of the Findhorn for an unknown period. Of gigantic stature, six feet seven inches in height, he was equally remarkable for his strength, courage, and celebrity as a deer-stalker, and had the best

* A portrait of this devoted partizan of the honse of Stuart was exhibited at the meeting of the British Association at Aberdeen in 1859 . 
"long dogs" or deer-hounds in the country. One winter's day, about the year before mentioned, he received a message from the Laird of MacIntosh that a large "black beast," supposed to be a Wolf, had appeared in the glens, and the day before killed two children, who with their mother were crosising the hills from Calder, in consequence of which a "Tainchel " or "gathering" to drive the country was called to meet at a tryst above Fi-Giuthas, where MacQueen was invited to attend with his dogs. He informed himself of the place where the children had been killed, the last tracks of the Wolf, and the conjectures of his haunt, and promised his assistance.

In the morning the "Tainchel" had long assembled, and MacIntosh waited with impatience, but MacQueen did not arrive. His dogs and himself were, however, auxiliaries too important to be left behind, and they continued to wait until the best of a hunter's morning was gone, when at last he appeared, and MacIntosh received him with an irritable expression of disappointment.

"Ciod e a chabhag?" ("What was the hurry?") said he of Pall-à-chrocain.

MacIntosh gave an indignant retort, and all present made some impatient reply.

MacQueen lifted his plaid and drew the black, bloody head of the Wolf from under his arm!

"Sin e dhiibh!" ("There it is for you !") said he, and tossed it on the grass in the midst of the surprised circle.

MacIntosh expressed great joy and admiration, 
and gave him the land called Sean-achan for meal to his dogs."

Sir 'Thomas Dick Lauder, in his "Account of the Moray Floods of August, I829," tells the story of the Wolf killed in that district by MacQueen of Pall-ì-chrocain, but lays the scene of the exploit in the parish of Moy, in the county of Inverness, which, although within the bounds of the ancient province of Moray, is far beyond the present limits of the forest of Tarnaway.

Sir Thomas gives the very words which MacQueen is said to have used in describing to the chief of MacIntosh how he killed the wolf: "As I came through the slochk (i.e., ravine) by east the hill there," said he, as if talking of some everyday occurrence, "I foregathered wi" the beast. My long dog there turned him. I buckled wi' him, and dirkit him, and syne whuttled his craig (i.e., cut his throat), and brought awa' his countenance for fear he might come alive again, for they are very precarious creatures." In reward for his bravery, his chief is said to have bestowed on him a gift of the lands of Sean-achan "to yield meal for his good greyhounds in all time coming." Sir Thomas Lauder has preserved another tradition of the extirpation of the Wolf in Morayshire, when two old Wolves and their cubss were killed by one man in a ravine under the Knock of Braemory, near the source of the Burn of Newton.

In the old "Statistical Account of Scotland," edited by Sir Joln Sinclair, and published in twenty-one rolumes between the years I79I and 
1799, a fer entries relating to the Wolf occur, but they are neither numerous nor important. Mr J. A. Harvie Brown, who has lately examined the entire series of volumes for another purpose, has obligingly communicated the following particulars: "The woods in Blair Athole and Strowan in Perthshire once afforded shelter for Wolves (vol. ii. p. 486), as did also the district around Cathcart in Renfrewshire (vol. v. p. 347). In Orkney it appears they were unknown (vol. vii. p. 546). The wilds and mountains of Glenorchay and Imnishail in Argyllshire are noted as being formerly haunted by these animals, whence they issued to attack not only the flock but their owners (vol. viii. p. 343). Towards the west end of the parish of Birse in Aberdeenshire there is a place in the Grampians still known ( I793) by the name of the Wolf-holm (vol. ix. p. ro8). Ubster, a town in Caithness (from 'Wolfster,' Danish or Icelandic), appears to have received its name either from its being of old a place infested with Wolves, or from a person of the name of Wolf (vol. x. p. 32). In Banffshire the last Wolf is said to have been killed in the parish of Kirkmichael about i 644" (vol. xii. p. 447).

Dr. Robert Brown heard a tradition in Caithnessshire that the wood on the hills of Yarrow, near Wick, was cut down about the year 1500 by the enraged dwellers in the district on account of its harbouring Wolves, and that the last Wolf in that neighbourhood was killed between Brabster and Freswick in a hollow called Wolfsburn. 
The place where the last Wolf that infested Monteith was killed is a romantic cottage south-west of the mill of Milling, in the parish and barony of Port.*

"The devastations of Oliver Cromwell in the vast oak and fir woods of Lochaber are well known, and in 1848 the old people still retained traditions of the native clearances in the same century, when the great tracts south of Loch Treig and upon the Blackwater were set on fire to exterminate the Wolves." $\dagger$

In the Edderachillis district, forming the western portion of what is called Lord Reay's country, a tradition existed to the effect that Wolves were at one time so numerous that to avoid their ravages in disinterring bodies from their graves, the inhabitants were obliged to have recourse to the island of Handa as a safer place of sepulture.

The Earl of Ellesmere, referring to an extract from the journal of his son, the Hon. Capt. Francis Egerton, R.N., written in India, and relating to an apparently well authenticated story of some children in Oude who were carried away and brought up by Wolves, § says: "It is odd that the same tale should extend to the Highlands. I got a story identical in all its particulars of the Wolf time of Sutherland from the old forester of the Reay, in which district Gaelic tradition avers that Wolves so abounded that it was usual to bury the dead in the Island of Handa to avoid desecration of the graves."

* Nimmo's "Stirlingshire," pp. 745, 750.

+ Stuart, "Lays of the Deer Forest," ii. p. 22 I.

+ Wilson's "Voyage round Scutland," vol, i. p. 346.

§ "Aun. and Mag. Nat. Hist.," second series, viii. p. I 53 . 
There is a tradition on Loch Awe side, Argyllshire, that Green Island was used as a burial-place for the same reason.*

In like manner an island in Loch Maree, Ross-shire, was for the same reason selected for a similar purpose. ${ }^{\prime}$

On the western shores of Argyllshire the small isle of St. Mungo, still used as a burial-place, has been appropriated to this purpose from the days when the Wolves were the terror of the land, the passage between it and the mainland opposing a barrier which they in vain attempted to cross. $\ddagger$

In Athole it was formerly the custom to bury the dead in coffins made of five flagstones to preserve the bodies from Wolves. $\$$

When treating of the Wolf in England it was observed that many names of places compounded of "Wolf" indicate in all probability localities where this animal was at one time counmon. The same may be said of Scotland. Chalmers cites in Roxburghshire, "Wolf-cleugh" in Roberton parish on Borthwick Water ; "Wolf-cleugh" on Rule Water;" and "Wolfhope" on Catlee-burn, in Southdean parish ; t to which may be added "Wolflee" or "Woole," on Wauchopeburn; and "Wolfkeilder" on the Northumbrian border. There are also "Wolf-gill land," in the

* This island is still used as a burying-ground. Mr. Harvie Browu saw fresh graves there in May, IS79.

† Macculloch's "Western Isles," quoted in Chambers' "Gazettecr of Scotland," p. 755.

¥ Constable's Edinburgh Magazine, Nov. I817, p. 340 .

$\S$ "Statistical Account of Scotland" (1972), vol. ii. p. 465.

|| Chambers' "Caleclonia," vol. ii. p. I32. 
parish and shire of Dumfiries, and "Wolfstan," in the parish of Pencaitland, East Lothian.*

Craigmaddie, "the rock of the Wolf," in the parish. of Baldernock, and Stronachon, "the ridge of the dog," in the parish of Drymen, point by their name to localities in Stirlingshire which were formerly the launts of the Wolf.

Mr. Hardy states (l.c.) that on the farm of Godscroft a cairn, now removed, was called "Wolf-camp." It may have been a Wolf's den, or perhaps an ancient "meet" of the Wolf-hunters who were summoned by. the sheriff in the days of the early Kings James.

He adds that in 1769 there was a farm called "Burnbrae" and "Wolfland" in the parish of Nenthorn belonging to Kerr of Fowberry. The name seems to imply that it had been held in former times by the tenure of hunting the Wolf; Jands thus granted being called "Wolf-hunt lands," as already remarked under the head of the Wolf in England.

In I 756 Buffon was assured by Lord Morton, thenPresident of the Royal Society, " a Scotsman worthy of the greatest credit and respect, and proprietor of large territories in that country," that Wolves still: existed in Scotland at that date.

William Smellie, the translator and editor of. Buffon's "Natural History," thus comments on this. statement (vol.iv.p. 2 I o, note, 3rd edit., I 79 I): "We are fully disposed to give due weight to an authority so respectable and so worthy of credit; but we are convinced that the Count has misapprehended his.

* Hardy, "Proc. Berwickshire Naturalists' Club," i 861, p. 289. 
lordship, for it is universally known to the inhabitants of Scotland that not a single Wolf has been seen in any part of that country for more than a century past."

In asserting that this is universally known to the iuhabitants of Scotland, the translator and editor has erred in the other extreme, for, as has been already shown, Wolves were killed in Sutherland within fifty years of the date of his remark and within thirteen years of the date mentioned by Buffon.

\section{Historical Evidence.-Ireland.}

From the scanty and more or less inaccessible nature of the records relating to the natural history of Ireland, compared with what exists in the case of England and Scotland, the result of a search for materials for a history of the Wolf in Ireland has proved less satisfactory than could have been wished. Nevertheless, some curious fragments of information on the subject have been collected from various sources, and are now brought together for the first time.

There is abundant evidence to show that Wolves formerly existed in great numbers in Ireland, and that they maintained their ground for a longer period there than in any other part of the United Kingdom. In bygone ages they must have fared sumptuously amongst the herds of reindeer and Irish elk, which at one time were contemporary with them; and the discovery of numerous skeletons, often entire herds of deer, imbedded in the mud of ancient lakes, has led to the surmise that these 
animals probably perished in this way in their. attempts to escape from packs of pursuing Wolves.

Giraldus Cimbrensis, who lived in the reigns of Henry II., Richard I., and Jolin, and who visited Ireland in I $S_{3}$ and again in I $185-6$, when he accompanied Prince John there, has left a curious account of the wild animals then existing in Ireland, amongst which is included the Wolf. He adds, "the Wolves often have whelps in the month of December, either in consequence of the great mildness of the climate, or rather in token of the evils of treason and rapine, which are rife here before their proper. season." 将

In the "Polychronicon" of Ranulphus Higden, the monk of Chester, who died about I360, we have a later account of the Irish fauna, and in this also the Wolf figures. Thus he says:- "Terra hac magis vaccis quam bolus, pascuis quam fiugibus, gramine quam grano fecunda. Abundat tamen salmonibus, murcenis, anguillis, et coteris marinis piscibus; aquilis quoque, gruitus, pavonibus, coturnicibus, niso, falcone et acciptre generoso. Lupos quoque labet, mures nocentissimos; sed et araneas, sanguisugas, et lacertas habet innocuas. Mustelas quoque parvi corporis sed valde animosas possidet. This passage is thus rendered by his translator, John Trevisa (A.D. I $357-$ I387), and adopted by Caxton in his "Cronycles of

* “Topographia Hiberniæ," lib. ii. cap. xxvi. p. 726, ed. Dimock, vol. v. p. II2. And not only Wolves, but crows and owls are said to have had young at Christmas. Op. cit., l. IIz.

† "Polychronicon Ranulphi Higden, Monachi Cestrensis," cd. Balbington (Master of the Rolls Serie 3), vol. i. pp. 334, 335. 
England," I 480 :-- "In this lond beeth mo kyn than oxen, more pasture than corne, more grass than seed. There is grete plente of samon, of lampreyes, of eles, and of other see fisch : of egles, of cranes, of pekokes, of corlewes, of sparhaukes, of goshaukes, and of gentil faucouns, and of Wolfes, and of wel shrewed mys. There beeth attercoppes, blood-soukers, and enettes that dooth noon harm," \&c." Some translators and later copyists have here and there singularly perverted the original meaning of this passage by blunders and mistranslations. Amongst these may be mentioned the author or authors of "The Book of Howth," a small folio in vellum of the sixteenth century, written in different hands, and preserved amongst the Carew MiSS. (vol. dexxiii.), in the Lambeth Library. ${ }^{+}$

* Some little interest attaches to this passage from the curious assemblage of animals named in it. At the period referred to "crancs" seem to have bccome common enough in Ireland: "in tanta vero numerositate se grues ingerunt, ut uno in grege centum, et circiter hunc mumerum frequenter invenias" "“Topog. Hibcrn.", ed. Dimock, v. 46). By "pekokes" (pavonibus), it would secm the capercaillie is intended, "pavones silvestres 7ic abundant," says Giraldus (tom. cit. p. 47). "Cotunnicibus" should be rendered "quails," not "curlews." "Item coturnicus hic plunimi," Girald.v. 47). "Mrures nocentissimos" are not necessarily shrew-mice, which are insectivorous. In all probability that destructivc little animal, the long-tailed field-mouse (Mus sylvaticus) is referred to. By reading "araneos" (shrews) for "araneas" (spiders) some confusion is accounted for. "Attercoppes" is the translation of waneas. Jamieson, in lis "Scottish Dictionary," gives "Atter-cap," "Attircop," spider, with two variants--Northumberland, "Attercop," and Cumberland, "Attercob," a cobireb. A. S. atter" coppe, from atter, venenum, and copp, calis; receiving its denomination partly from its form, and partly from its character; $q$. a cup of venom. By "bloodsuckers," of course, leeches are meant: for "enettes" lacertas we may read "euettcs" or" "evettes"-i.e., efts, that do no harm.

$+C f$. Brewer and Bullen, Calendar Carew MSS., "The Book of Howth," p. 3I. 
Campion, whose "History of Ireland" was published in 1570 , refers to the chase of the Wolf there with Wolf-hounds. "The Irish," hesays, "are not without Wolves, or greyhounds to hunt them; bigger of bone and limme than a colt." *

Sir James Ware, in his "Antiquities of Ireland" (I658), notices, "those hounds which, from their" hunting of Wolves, are commonly called 'Wolf-dogs,'

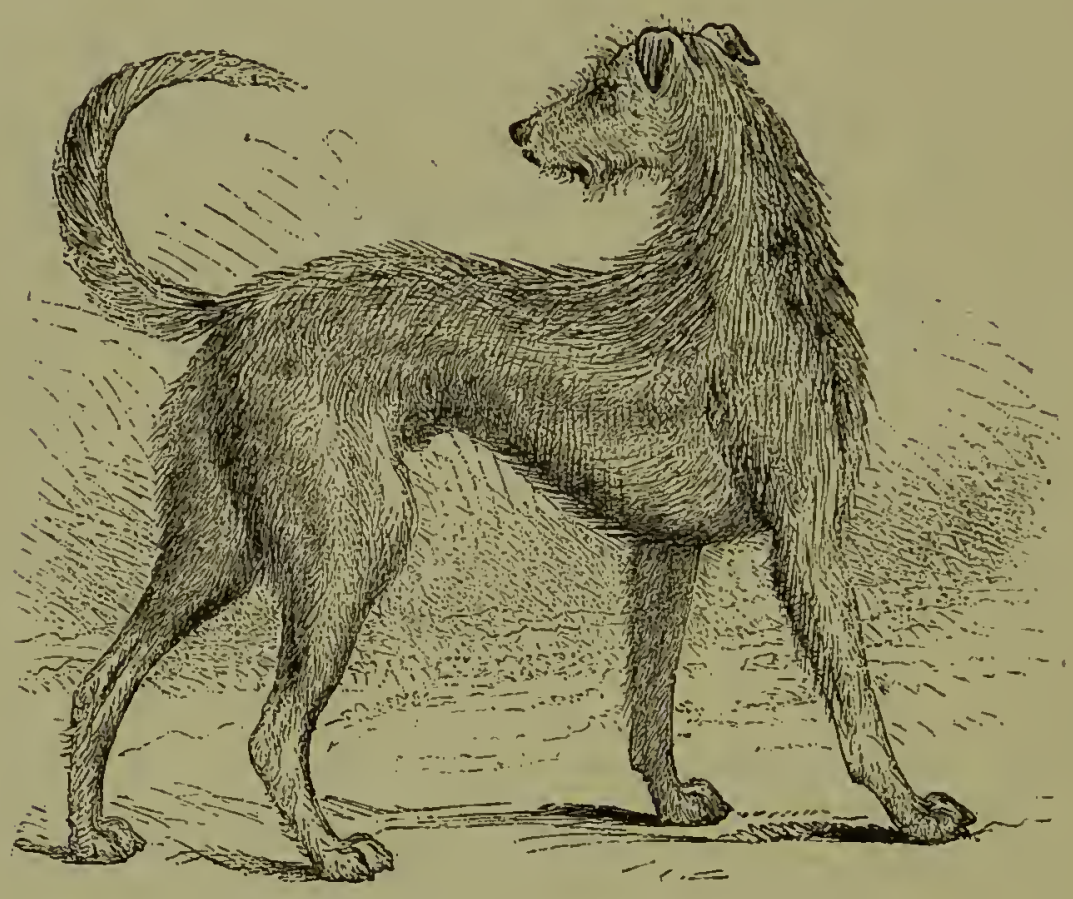

IRISII WOLF-HOUND.

being creatures of great strength and size, and of a fine shape."

Ray has described the Irish Wolf-hound as a tall, rough greyhound; so also has Pennant, who descants at some length on his extraordinary size and power.

The Wolf-hound here figured is a dog belonging to

* See also Holinshed, "Descrip. Irel." I 586 ; and Camden, "Britannia," vol. ii. p. 1312 (ed. Gibson). 
Capt. G. H. Graham, of Rednock, Dursley, Gloucestershire, and bred from the only authentic strain of Irish Wolf-hound now known. His dimensions are as follows:-Height, $29 \frac{1}{2}$ in. ; girth, $33 \frac{1}{2}$ in. ; length of head, I 2 in. ; girth of do. in front of ear's, I $8 \frac{3}{4} \mathrm{in}$; forearm, $8 \frac{1}{2} \mathrm{in}$. Weight, ro2 lbs.

In a Privy Seal from Henry VIII. to the LordDeputy and Council of Ireland, * his Majesty takes notice of the suit of the Duke of Albuquerque, of Spain (of the Privy Council to Henry VIII.), on behalf of the Marquis Desarrya and his son, "that it might please his Majesty to grant to the said Marquis and his son, and the longer liver of them, yearly, out of Ireland, two gosharvks, and four Wolfhounds," and commands the Deputy for the time being to order the delivery of the hawks and hounds, and to charge the cost to the Treasury.

In November, I562, as we learn from the State Papers relating to Ireland, $†$ the Irish chieftain, Shane O'Neill, forwarded to Queen Elizabeth, through Robert Dudley, Earl of Leicester, a present of two. horses, two hawks, and two Irish Wolf-dogs. In I585, Sir John Perrott, who was Lord-Deputy of Ireland from January, I 584, to July, I 588 , \$ sent to Sir Francis Walsingham, then Secretary of State in London, "a brace of good Wolf-dogs, one black, the other white."

Again, in 1608, we find that Irish Wolf-hounds. were sent from Ireland by Captain Esmond, of

$$
\text { * Rot. Canc. Dec. 9, } 36 \text { H. 8, dorso. }
$$

† Eliz., vol. vii. No. 40, in Pub. Rec. Off. \$ Eliz., vol. cxx. No. 12. 
Duncannon, to Gilbert, seventh Earl of Shrews. bury.*

These dogs were considered very valuable, and were highly thought of by those who received them as presents; but some years later, when, owing to the great increase in the number of 'Wolves in some parts of Ireland, their services were more than ever required to keep down these ferocious animals, a law, presently to be noticed, was passed to prohibit their exportation.

About this time George Turbervile, a gentleman of Dorsetshire, was writing his "Booke of Hunting;" $\uparrow$ in which, referring to this animal, he says:- "The Wolf is a beaste sufficiently known in France and other countries where he is bred; but here in England they be not to be found in any place. In Ireland, as I have heard, there are great store of them; and because many noblemen and gentlemen have a desire to bring that countrie to be inhabited and civilly governed (and would God there were more of the same mind), therefore I have thought good to set down the nature and manner of hunting the Wolf according to mine author." $\ddagger$ He then proceeds to describe the mode then in vogue of hunting this animal. An open spot was generally chosen, at some distance from the great coverts where the Wolves were known to lie, and here, in concealment, a brace, sometimes two brace, of Wolf-hounds were * "Archrol. Aliana," vol. ii. n. 226.

+ "Imprinted at London for Christopher Barker at the sigue of the Grashopper in Paules Churchyarde. Anno 1575."

‡ Jacques de Fouillonx, "T'raité de Vénerie." 
placed. A horse was killed, and the fore-quarters were trailed through the paths and ways in the wood during the previous day, and back to where the carcase lay, and there they were left. When night approached, out came the Wolves, and having struck the scent, they followed it until they found the dead horse, when of course they began to feed on the flesh, and early in the morning, just before daybreak, the hunters placed their dogs so as to prevent the Wolves from returning to cover. When a Wolf came to the spot, the men in charge of the Wolfhounds suffered him to pass by the first, but the last were let slip full in his face, and at the same instant the others were let slip also, so that, the first staying him ever so little, he was sure to be attacked on all sides at once, and therefore, the more easily taken.*

In Robert Legge's "Book of Information," compiled in 584 by order of Sir John Perrott, the abovenamed Lord-Deputy of Ireland, "for the information of the civil government of that realm," it is recommended, inter alia, that for the "destruction of ravening and devouring Wolves, some order might be had, as when any lease is granted, to put in some clause that the tenant endeavour himself to spoil and kill Wolves with traps, snares, or such devices as he may devise." $†$

* The most complete account which we have met with of Wolfhunting in modern times is that given by Col. Thornton in his "Sporting Tour through various parts of France in 1802," vol. i. pp. xxi-xxxix. A more recent treatise, however, has been published under the title of "Wolf-hunting in Brittany."

+ Carew MSS., vol. devii. p. I I5. Brewer and Bullen, Calendar of Carer M.SS., Eliz., p. 40r. 
About this time, it is said, Wolves committed great devastation amongst the flocks in Munster. After the destruction of Kilmallock by James Fitzmaurice, in 1591, that place is stated to have become the haunt of Wolves.

For some account of their ravages during Desmond's rebellion, the reader may be referred to O'Sullivan's "Compendium Historiæ Catholicæ Hiberniæ," I 62 I (lib. viii. cap. 6).

At a later period, according to Fynes Moryson, who was Secretary to Lord-Deputy Mountjoy, and who wrote a "History of Ireland from I 599 to I603," the cattle had to be driven in at night, "for. fear of thieves (the Irish using almost no other kind of theft), or else for fear of Wolves, the destruction whereof being neglected by the inhabitants, oppressed with greater mischiefs, they are so much grown in numbers as sometimes on winter nights they will come and prey in villages and the suburb.s of cities."*

In May, 1594, Lord William Russell was appointed Lord-Deputy of Ireland by Queen Elizabeth. From entries in his "Journal," extending from "June 24, I 594, to May 27, I 597," "† it appears that both he and Lady Russell, who accompanied him to Ireland, frequently participated in the pleasures of the chase, and amused themselves at different times with hawking, fishing, and hunting. Under date May 26, I 596, it is recorded: "My Lord and Lady rode

* Moryson, "Hist. Ireland," Dublin ed., I735, rol. ii. p. 367.

+ Preserved amongst the Carew MSS. at Lambeth Palace, vol. dexii. 
abroad a hunting the Wolf." As the Vice-regal Court was then located at Kilmainham, almost within the city of Dublin, it would appear that the Wolf in question was to be found at no great distance beyond the city walls,

Sir Arthur Chichester, writing to Sir John Davys, March 3 I, I609, in reference to the pending plantation of Ulster, incidentally remarks, that "if the Irish do not possess and inhabit a great part of the lands in some of those escheated countries, none but Wolves and wild beasts would possess them for many years to come; for where civil men may have lands for reasonable rents in so many thousand places in that province, and in this whole kingdom, they will not plant themselves in mountains, rocks and desert places, though they might have the land for nothing:"**

In the reign of James $I$. it would seem that active measures were advised for the destruction of Wolves in Ireland, and the following "Heads of a Bill in the Irish Parliament, I6r I," will be found preserved amongst the Carew MSS., formerly in the Record Office, but now at Lambeth Palace : $t$ "An Act for killing Wolves and other vermin, touching. the days of hunting, the people that are to attend, who to be their director, an inhibition not to use any arms. The Lord Deputy or Principal Governor to prohibit such hunting if he suspect that such assemblies by colour of hunting may prove inconvenient."

* State Papers, Ireland, in Record Office, vol. ccxxvi, 58.

† Carew, MSS., vol. dexxix. p. 35. Scealso Hamilton's "Calendar of State Papers referring to Ireland," Jac. I., sub anno, p. 192. 
This proposed Act, however; seems never to have become law, for no mention of it is made in the eiglnt volumes of Irish Statutes published by authority in Dublin in 1765 . It is not surprising therefore that the ravages of the Wolves in Ireland continued. In I 6 I 9 their numbers in Ulster compelled people "to house their cattle in the bawnes of their castles, where all the winter nights they stood up to their bellies in dirt. Another reason is to prevent thieves and false-hearted brethren who have spies abroad, and will come thirty miles out of one province into another to practise a cunning robbery."

Howell, in one of his "Familiar Letters," written to Sir James Crofts, September 6th, I624, says :-A pleasant tale I heard Sir Thomas Fairfax relate of a souldier in Ireland, who having got his passport to go for England, as he past through a wood with his knapsack upon his back, being weary, he sate down under a tree wher he open'd his knapsack and fell to some victuals he had; but upon a sudden he was surpriz'd with two or three Woolfs, who, coming towards him, he threw them scraps of bread and cheese till all was done; then the Woolfs making a nearer approach unto him, he knew not what shift to make, but by taking a pair of bagpipes which he had, and as soon as he began to play upon them, the Woolfs ran all away as if they had been scar'd out of their wits. Whereupon the souldier said, "A pox take you all, if I had known you had lov'd musick so well, you should have had it before dimner!"

* Gainsford's "Glory of England," p. 148. 
In I64 I and i 652 Wolves were particularly troublesome in Ireland, and in the latter year the following Order in Council was issued by Cromwell, prohibiting the exportation of Wolf-dogs :-

\section{"Declaration against transporting of Wolfe Dogges.}

"Forasmuch as we are credibly informed that Wolves doe much increase and destroy many cattle in several partes of this Dominion, and that some of the enemie's party, who have laid down armes, and have liberty to go beyond sea and others, do attempt to carry away such great dogges as are commonly called Wolfe dogges, whereby the breed of them which are useful for destroying of Wolves would (if not prevented) speedily decay. These are therefore to prohibit all persons whatsoever from exporting any of the said dogges out of this Dominion; and searchers and other officers of the Customs, in the several partes and creekes of this Dominion, are hereby strictly required to seize and make stopp of all such dogges, and deliver them either to the common huntsman, appointed for the precinct where they are seized upon, or to the governor of the said precinct.

"Dated at Kilkenny, April 27, i 65 2."

The following year another Order in Council was made which ran as follows :-

\section{"Declaration touching Wolves.}

"For the better destroying of Wolves, which of late years have much increased in most parts of this 
nation, it is ordered that the Commanders in Chiefe and Commissioners of the Revenue in the several precincts doe consider of, use, and execute all good wayes and meanes how the Wolves in the counties and places within the respective precincts may be taken and destroyed; and to employ such person or persons, and to appoint such daies and tymes for hunting the Wolfe, as they shall adjudge necessary. And it is further ordered that all such person or persons as shall take, kill, or destroy any Wolfes and shall bring forth the liead of the Wolfe before the said commanders of the revenue, shall receive the sums following, viz., for every bitch Wolfe, six pounds; * for every dog Wolfe, five pounds; for every cubb which preyeth for himself, forty shillings; for every suckling cubb, ten shillings. And no Wolfe after the last September until the roth January be accounted a young. Wolfe, and the Commissioners of the Revenue shall cause the same to be equallie assessed within their precincts.

\section{"Dublin, June 29, I 653 3. †}

The assessments here ordered fell heavily in some districts. Thus in December, 1665, the inhabitants of Mayo county petitioned the Council of State that the Commissioners of Assessment might be at liberty

* The price paid in Sutherlandshire, in I62I, was 6l. I3s. $4 \pi$. See p. I69.

$\uparrow$ These documents were extracted from the original Privy Council Book of Cromwell's government in Ireland, preserved in Dublin Castle and are quoted by Hardiman in his edition of O'Flaherty's "West or H'Iar Connaught," p. I8o. 
to compound for Wolf-heads; which was ordered accordingly.

In I662, as appears by the Journal of the House of Commons, Sir John Ponsonby reported from the Committee of Grievances that a Bill should be brought in "to encourage the killing of Wolves and foxes in Ireland."

In the "Travels of the Grand Duke Cosmo III. in England," I 669 (p. I03), the author speaks of Wolves as common in Ireland, "for the hunting of which the dogs called "mastiffs' are in great request."

O'Flaherty, in his "West or H'Tar Comnaught" (1684), enumerates the wild animals which were to be found in that district in his day, and names "Wolves, deere, foxes, badger's, hedgehogs, hares, rabbets, squirrells, martens, weesles, and the amphibious otter, of which kind the white-faced otter is very rare." Hardiman, in a note to his edition of this work (1846), says: "When our author wrote (1684), and for some years afterwards, wolves were to be found in Iar Connaught, but not in such numbers as in the early part of that century. The last Wolf which I have been able to trace here was killed in the mountains of Joyce country, in the year I 700. After the wars of I64I the ravages of the Wolves were so great throughout Ireland as to excite the attention of the State. 'Wolf-hunters' were appointed in various districts, and amongst others in Iar Connaught, who helped to rid the country of these ferocious animals."**

* Hardiman, op. cit., p. Io, note. 
In an account of the British Islands, published at Nuremberg in 1690, the wilds of Kerry are referred to as harbouning Wolves and foxes; $*$ and in the reign of William and Mary, Ireland was sometimes called by the nickname of "Wolf-land." Thus in a poem on the Battle of La Hogue, I692, called "Advice to a Painter," the terror of the Irish army is described :-

A chilling damp,

And Wolf-land howl runs through the rising camp.

"Three places in Ireland are commemorated, each as having liad the last Irish wolf killed there-namely, one in the south, another near Glenarm, and the third, Wolf-hill, three miles from Belfast."' one in the south is probably that referred to in Edwards's "Cork Remembrancer" (p. I3 I), wherein the following entry occurs: "This year (I 7 Io) the last presentment [to the Grand Jury] for killing wolves was made in the county of Cork." $\ddagger$ In the old "Statistical Account of Scotland," however, edited by Sir John Sinclair, it is stated (vol. xii. p. 447) that the last was killed in Ireland. in 1709.

The great woods of Shillela, on the confines of Carlow and Wicklow, now the property of Earl Fitzwilliam, are said to have held Wolves until about the year i 700 , when the last of them was destroyed in the neighbourhood of Glendaloch. $\$$

* This work we have not. seen. It is quoted by Macaulay, in his "History of England," vol. iii. p. 136.

† Thompson, "Nat. Hist., Ireland," vol. iv. p. 34.

+ See also Scouler, "Journ. Geol. Soc.," Dublin, vol. i. p. 226.

$\S$ Mackenzie's "Natural History," p. 20. 'This volume, published in London in modern times, is undated. 
In a poem, in six cantos, published as late as I 7 I 9 , and entitled, "MacDermot, or the Irish FortuneHunter," "Wolf-hunting" and "Wolf-spearing" are represented as common sports in Munster. Here is an extract :-

"It happen'il on a day with horn and hounds,

A baron gallop'd through MacDermot's grounds, Well hors'd, pursuing o'er the dusty plain

A Wolf that sought the neighbouring woods to gain :

Liac hear's th' alarm, and, with his oaken spear,

Joins in the chase, and runs before the peer,

Outstrips the huntsman, dogs, and panting steeds, And, struck by him, the falling savage bleeds."

The crest of the O'Quins of Munster is "a Wolf's head, erased, argent," possibly perpetuating the prowess of some former noted Wolf-hunter in that ancient family.

The author of "The Present State of Great Britain and Ireland," printed in London in $173^{8}$, wrote at that date, "Wolves still abound too much in Ireland; they pray for the Wolves, least they should devour them."

In Smith's "Ancient and Modern State of the County of Kerry," I756 (of which book Macaulay said, "I do not know that I have ever met with a better book of the kind and of the size," "Hist. Eng:" iii. I 36), the author, speaking of certain ancient enclosures, observes (p. 1 73) that many of them were made to secure cattle from Wolves, which animals were not entirely extirpated until about the year I 7 IO, as I find by presentments for raising money for destroying them in some old grand-jury books."

Traces of old circular entrenchments, into which 
cattle and sheep were driven for protection from Wolves, are still to be seen in many parts of Ireland, especially in the south. One of these, in the county. 'Tyrone, will be noticed presently.

In Harris's edition of Sir James Ware's "Works" (Dublin, 1764), the editor, commenting upon the passage, "I shall but just hint at the eagerness of the Irish in the chase, as in hunting Wolves and stags," remarks in a footnote (p. 165), "So said in the year I658. But there are no Wolves in Ireland now." This statement in turn may be controverted upon very respectable authority, but the conflict of evidence renders it very difficult to fix with certainty the precise date at which the animal became extinct.

The following account is given of the destruction, by a noted Wolf-hunter, of the last Wolves in the county Tyrone :-

"In the mountainous parts of the county Tyrone, the inhabitants suffered much from Wolves, and gave as much for the head of one of these animals as the $y$ would now give ( 1829 ) for the capture of a notorious robber on the highway. There lived in those days an adventurer who, alone and unassisted, made it his occupation to destroy those ravagers. The time for attacking them was at night. There was a species of dog kept for the purpose of hunting. them, resembling a rough, stout, half-bred greyhound, but much stronger.

"In the county Tyrone there was then a large space of ground enclosed by a high stone wall, having a gap at the two opposite extremities, and in this. 
were secured the flocks of the surrounding farmers. Still, secure though this fold was deemed, it was entered by the Wolves, and its inmates slaughtered.

"The neighbouring proprietors having heard of the noted Wolf-hunter above mentioned, by name Rory Carragl, sent for him and offered the usual reward, with some addition, if he would undertake to destroy the two remaining Wolves that had committed such devastation. Carragh, undertaking the task, took with him two Wolf dogs and a little boy, the only person he could prevail on to accompany him, and, at the approach of night, repaired to the fold in question.

" 'Now,' said Carragh to the boy, 'as the Wolves usually attack the opposite extremities of the sheepfold at the same time, I must leave you and one of the dogs to guard this one, while I go to the other. He steals with all the caution of a cat; nor will you hear him, but the dog will, and will positively give him the first fall. If you are not active when he is down, to rivet his neck to the ground with this spear, he will rise up and kill both you and the dog.'

"'I'll do what I can,' said the boy, as he took the spear from the Wolf-hunter's hand.

"The boy immediately threw open the gate of the fold, and took his seat in the inner part, close to the entrance, his faithful companion crouching at his side and seeming perfectly aware of the dangerous business he was engaged in. The night was very dark and cold, and the poor little boy being benumbed with the chilly air, was beginning to fall into a kind of sleep, 
when at that instant the dog, with a roar, leaped across him and hiid his mortal enemy upon the earth. The boy was roused into double activity by the voice of his companion, and drove the spear through the Wolf's neck, as he had been directed; at which time Carragh made his appearance with the head of the other." "*

In an interesting article on the Irish Wolf-dog, published in 'The Irish Penny Journal for $184^{1}$ (p. 354), the writer says :t-“ I am at present acquainted with an old gentleman between eighty and ninety years of age, whose mother remembered Wolves to have been killed in the county of Wexford about the years 1730-40, and it is asserted by many persons of weight and veracity that a Wolf was killed in the Wicklow mountains so recently as I 770.

A few years since, Sir J. Emerson Tennent wrote on this subject as follows:-

"Waringstown, in the county of Down, on the confines of the county of Armagh, takes its name from the family of Waring, which, in the reign of Queen Mary, fled to Ireland from Lancashire to avoid the persecution of the Lollards. At the close of the seventeenth century the Waring of that day was a member of the Irish Parlianent; and his eldest son, Samuel Waring, was born about the year I699, and

* "The Biography of a Tyrone Family" (Belfast, I S29), p. 74.

+ This article, published under the initials of H. D. R., has since been admitted to have been written by H. D. Richardson, author of "The Dog: its Origin, Natural History, and Varieties," in which work it las been embodied with additions, 1848 . 
died at a very advanced age in 1793. He was succeeded by his nepherv, the Very Reverend Holt Waring, Dean of Dromore, who was born in 1766 , and whom I had the honour to know. With him I happened to be travelling through the Mourne mountains, in the county of Down, on our way to the Earl of Roden's, about the year 1834 or 1835 , when the conversation turning upon the social condition of Ireland in the previous century, lietold me that a foal belonging to his uncle had been killed by a Wolf in the stable at Waringstown, and that he, when a boy, had heard the occurrence repeatedly adverted to in the family circle. The dean was a man of singularly acute mind and accurate memory, and unless this statement of his be altogether a delusion, this would seem to be the last recorded appearance of a Wolf in Ireland."

The last piece of evidence collected has reference to a communication which appeared in The Zoologist for 1862 (p. 7996), under the heading, "Wolf Days of Ireland." On applying to the writer, Mr. Jonathan Grubb, of Sudbury, for further particulars, he obligingly replied in a letter, dated June 6, I 877 , as follows :-

"I am now in my seventieth year. My father, who was born in 1767 , used to tell the Wolf stories to us when we were children. His mother-ny grandmother-related them to him. She was born in r73r. Her maiden name was Malone; and her uncles, from whom she received her information, were the actors in the scenes described at Ballyroggin, county Kildare. She remembered one of them, 
James Malone, telling her how lis brother came home one night on horseback pursued by a pack of Wolves, who overtook him, and continued leaping on to the hind quarter's of his horse till he reached his own door, crying out, 'Oh! James, James! my horse is ate with the Wolves.'"

The precise date of this occurrence cimnot now be fixed; but it seems plain that Wolves existed in Kildare during the first quarter of the eighteentlı century, and perhaps as late as I $72 \mathrm{I}$.

To sum up. So far as can be now ascertained, it appears that the Wolf became extinct in England during the reign of Henry VII. ; that it survived in Scotland until I 743; and that the last of these animals was killed in Ireland, according to Richardson, in I 770 , or, according to Sir James Emerson Tennent, subsequently to i 766 .

In the foregoing observations, no reference has been made to "Were-wolves," nor has any matter been introduced touching the fabulous or superstitious aspect of the Wolf"s history in the British Islands. All such allusions have been purposely avoided, in order to confine the subject within reasonable limits.

Before concluding, however, we may perhaps be excused for citing so respectable an authority as Sir Thomas Browne, who, in his "Enquiries into Vulgar and Common Errors," has alluded to the popular notion that Wolves cannot live in England.

In vol. iii. p. 344, of his "Works" (Wilkin's edition), he says:- "Thus because there are no Wolves in England, nor have been observed for divers 
generations (1646), common people have proceeded into opinions, and some wise men into affirmations, that they will not live therein, although brought from other countries."

Ite also notices the popular belief that "a Wolf" first seeing a man begets a dumbness in him," a notion as old as the time of Pliny, who wrote: "In Italia, ut creditur, luporum visus est noxius, vocemque homini, quem prius contemplatur adimere." In France, when anyone becomes hoarse, the say "Il a vu le loup.".**

"The ground or occasional original thereof," says Sir Thomas Browne, $\uparrow$ "was probably the amazement and sudden silence the unexpected appearance of Wolves doth often put upon travellers, not by a supposed vapour or venomous emanation, but a vehement fear, which naturally produceth obmutescence, and sometimes irrecoverable silence."

A critic, adverting to this passage, has somewhat wittily remarked: "Dr. Browne did unadvisedly reckon this among his vulgar errors, for I believe he would find this no error if he were suddenly surprised by a wolf, having no means to escape or save himself !'

* Howell's "Familiar Letters;" vol. ii. p. 52.

$\dagger$ Op. cit., vol. ii. p. 422.

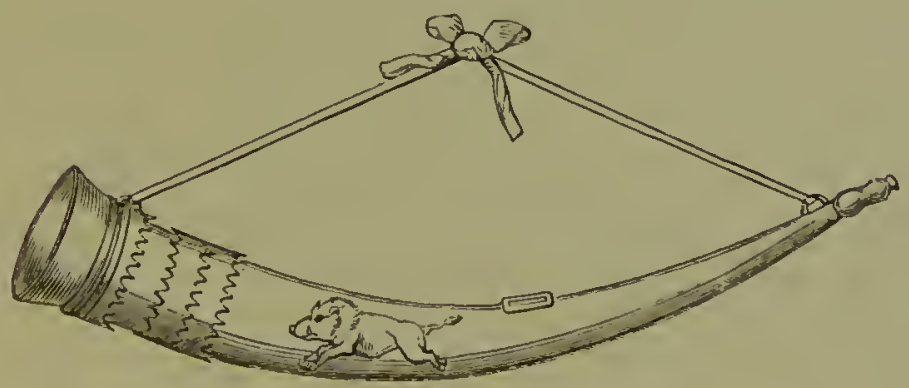




\section{CON C L US I O N.}

Is considering the causes, besides those already referred to, which have led to the extinction of the wild animals now under consideration, it should be borne in mind that for some centuries after the Norman Conquest they were not hunted down and destroyed by everybody and anybody, as they would be if they existed at the present day, but were strictly preserved under very severe penalties by the kings and powerful noblemen of the day for their own particular sport and recreation. William the Conqueror punished with the loss of eyes those convicted bf killing a wild boar, stag, or roebuck; and wolves and foxes, although reckoned neither as beasts of the forest nor of venery, could not be killed within the limits of the forest without a breach of the royal chase, for which offenders had to yield a recompense.

'The inveterate love of the chase possessed by William Rufus, which prompted him to enforce during his tragical reign the most stringent and cruel forest laws, is too well-known to readers of history to require comment. 
In his passion for humting wild animals Henry I. excelled even his brother William, and not content with encountering and slaying those which like the wolf and the wild boar, were at that time indigenous to this country, he "cherished of set purpose sundrie kinds of wild beasts, as bears, libards, ounces, lions, at Woodstocke, and one or two other places in England, which he walled about with hard stone (A.D. I I 2O), and where he would often fight with some one of them hand to hand."

Henry II. and John were both great preservers of wild animals, and monopolized large tracts of country wherein to indulge their passion for hunting. Ferocious animals were in consequence long suffered to remain at large against the will of the people, and hence survived to a much later period in this country than would have been the case had the subjects of these monarchs dared sooner to assert their independence. But at length came the repeal of the forest laws. The operation of the Charter of the Forests, which was signed by John at the same time with Magna Charta, restrained the worst abuses of the feudal tenure; all lands which had been converted into woods or parks since the commencement of this reign were disafforested, and the tenants bordering on the royal forests secured against spoliation; in a word, the laws made for the protection of the game and wild animals were either partially repealed or considerably mitigated.

A confirmation of this charter was obtained, though with much difficulty; from Henry III. It 
directed that all woods that had been taken in, or', as it was termed, afforested, to the prejudice of the owners, should be disafforested, and no more additions were to be made. Still further concessions on this score were made by Edward I.

From this time it may be said that the presence of ferocious animals in this country was no longer tolerated. They were slain wherever and whenever they could be found, and only managed to survive in reduced numbers, for some few centuries longer, in consequence of the utter impossibility of dislodging them from the almost impenetrable forests and mountain fastnesses to which they were driven. Later: on, when large tracts of forests were purposely cut down or burned for the purpose of expelling these animals, and statutes were put in force which rewarded the slayers of them, their extermination was finally accomplished.

Another cause which has doubtless contributed in no slight degree to the extinction of the above-mentioned animals, is the insular character of the country which they inhabited.

As civilization advanced, as forests were cut down, mosses drained and moorlands cultivated, they were driven further and further away, until finally their retreat was cut off by the sea. Unable to retire beyond so irresistible a barrier, they gradually succumbed to the attacks of their pursuers, or to the altered conditions of life, which deprived them per force of the means of existence. We have seen how fully this is exemplified in the case of the reindeer, whose last 
home in Britain was among the remote hills of Caithness.

To the naturalist it is a somewhat sad reflection, that animals of the forest and the chase, now only known by name as the inhabitants of other countries, were once as familiar to our ancestors as they are at present to the people of the remote kingdoms which they frequent. Man has been warring against these forest denizens, and as tract after tract which they once claimed as their own has been brought under the ploughshare, they have been driven farther and farther back, until the last of them has been blotted out from our fauna.

Lake and moor have become fields of yellow grain ; forest has been changed into morass, morass into moor, and moor again into forest, until finding nowhere to rest in peace, the bear, the beaver, the reindeer, the wild boar, and the wolf, have become in Britain amongst the things that were.

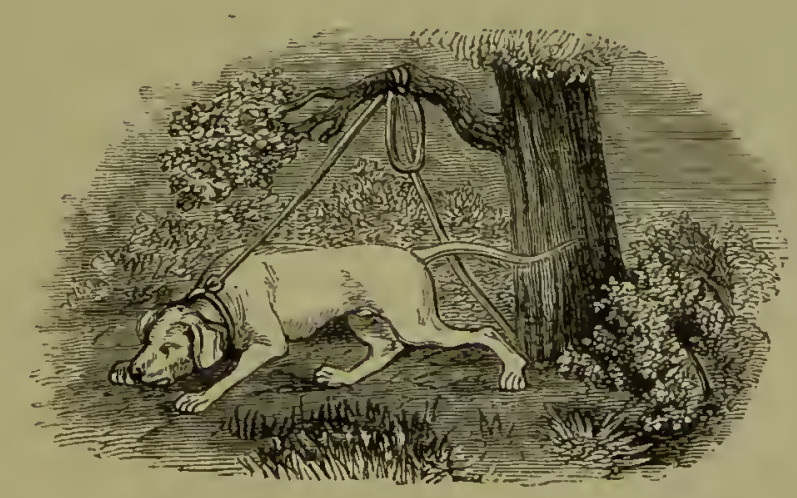





\section{PART II.}

\section{BRITISH WILD WHITE CATTLE.}





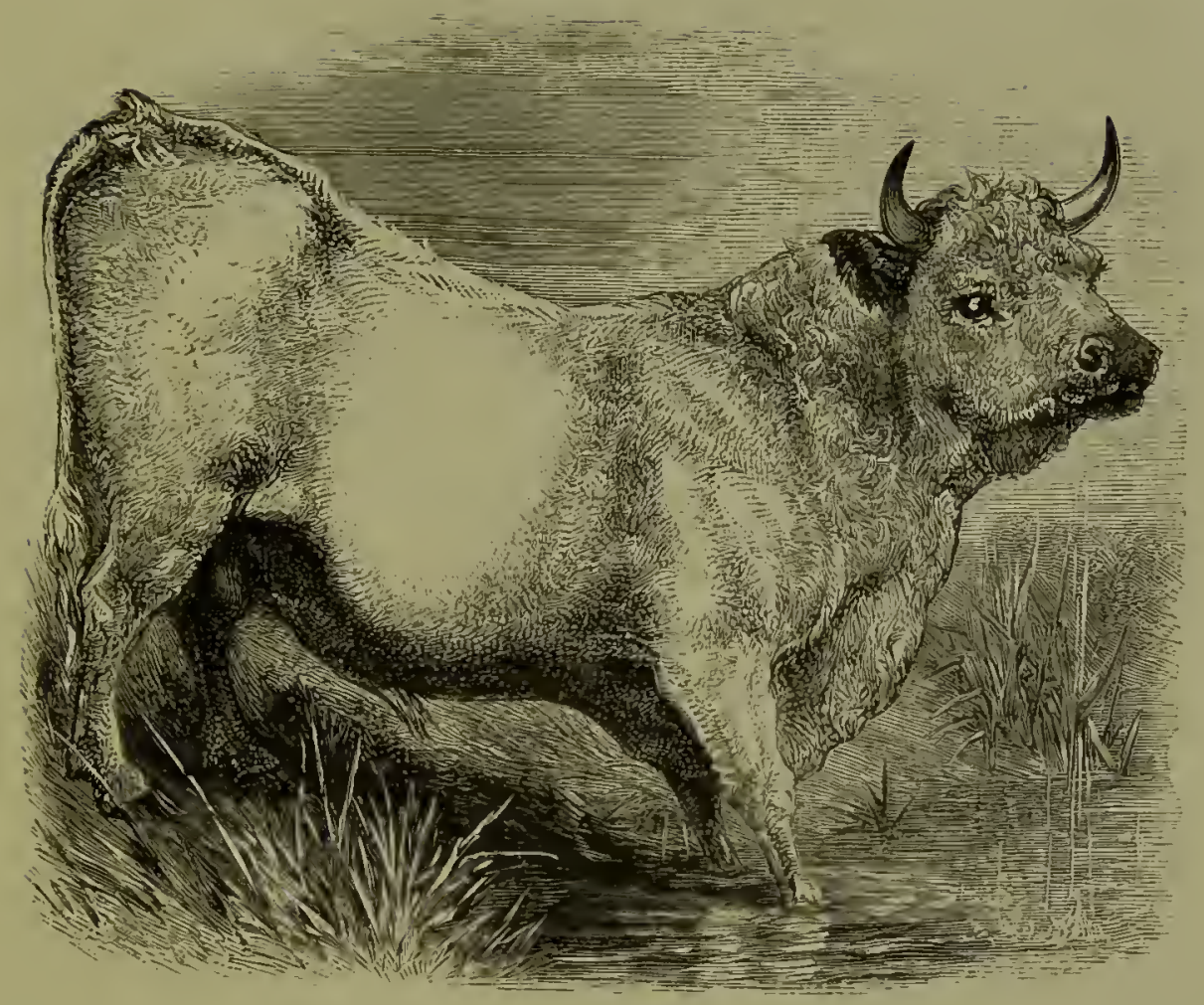

\section{WILD WHITE CATTLE.}

THe few scattered herds of so-called Wild White Cattle which still exist in parks in England and Scotland may be said to form a connecting link, as it were, between the wild animals which have become extinct in this country within historic times, and those which may still be classed amongst our ferce naturce.

The race is undoubtedly of great antiquity, but whether it is descended, as some affirm, from the 
aboriginal wild breed of the British forests-the Urus of Cessar (Bos primigenius)—or whether, as others assert, it has at some period long remote been imported from abroad and since become feral, are questions upon which, at present, considerable difference of opinion prevails. The weight of scientific opinion, however, seems to favour the view that these wild white cattle were descended from the Urus, either by direct descent through wild animals from the wild bull, or less directly through domesticated cattle deriving their blood principally from him. That the Urus existed in Britain in prehistoric times, and was contemporaneous with man of the Palæolithic or older Stone Age, must be admitted. In the fluviatile deposits of the Thames, and in some other places, the remains of the two have been found together, ${ }^{*}$ and instances have been recorded in which the remains of the Urus have been found contemporaneous with man of the Neolithic or later Stone Age. In the Zoological Museum at Cambridge, where there is a remarkably fine skeleton of this animal from Burwell Fen, may be seen the greater portion of a skull from the same locality, in which a neolithic celt was found, and still remains imbedded. $\dagger$ Another skull of this animal was found in a moss in Scotland, in conjunction with bronze

* The Rev. Samuel Banks, Rector of Cottenham, possesses a fine skull of the Urus, found in Cottenham Fen, the fractured bone of which clearly testifies that it was destroyed by a human weapon.

+ See Carter, Geological Magazine, November, 1874. Both the specimens here referred to are figured in Miller and Skertchley's "Fenland, Past and Present," p. 321. 
celts, indicating a still later period-the Bronze Age.

Mr. Woods has published a good description, with figures of the cranial part of the skull and horn-cores of Bos primigenius which were discovered in 1838 in the bed of the Avon, at Melksham, and has referred to similar remains found in the neighbourhoods of Bath, Tiverton and Newton St. Loe.*

In the Magazine of Natural History (1838, p. $\left.{ }_{6} 6_{3}\right)$, Mr. Brown of Stanway has recorded the discovery in a mass of drift sand overlying the London clay at Clacton, Essex, of a portion of the cranium with horn-cores of Bos primigenius, a very perfect skull of which has been admirably figured by Professor Owen, $\dagger$ from a specimen found at Athole, Perthshire, and preserved in the British Museum.

Fleming, in his "History of British Animals" ( 1828 ), has referred to a skull of this animal which is now preserved in the Museum of the New College, Edinburgh, and of which he has briefly given dimensions. It was found in a marl-pit at Newburgh, Fifeshire. Through the kindness of Dr. J. A. Smith, and by permission of the Society of Antiquaries of Scotland, we are here enabled to figure it from an illustration, slightly reduced, in Dr. Smith's excellent "Notes on the Ancient Cattle of Scotland," printed in the "Proceedings" of the Society referred to. To the proprietors of The Field we are also indebted for permission to make use of an engraving of an

* Woods' "Description of Fossil Skull of an Ox," 4to, 1839 .

†"British Fossil Mammals," p. 498. 
English skull of this animal, which, in The field of Apri] i 8, 1868, illustrated some remarks on its discovery from the pen of $\mathrm{Mr}$. W. B. Tegetmeier. This specimen was found in the bed of the Ribble, below Preston, Lancashire, in the spring of 1867 , and passed into the possession of $\mathrm{Mr}$. James Dobson of the Preston Chronicle, who kindly forwarded it for examination.

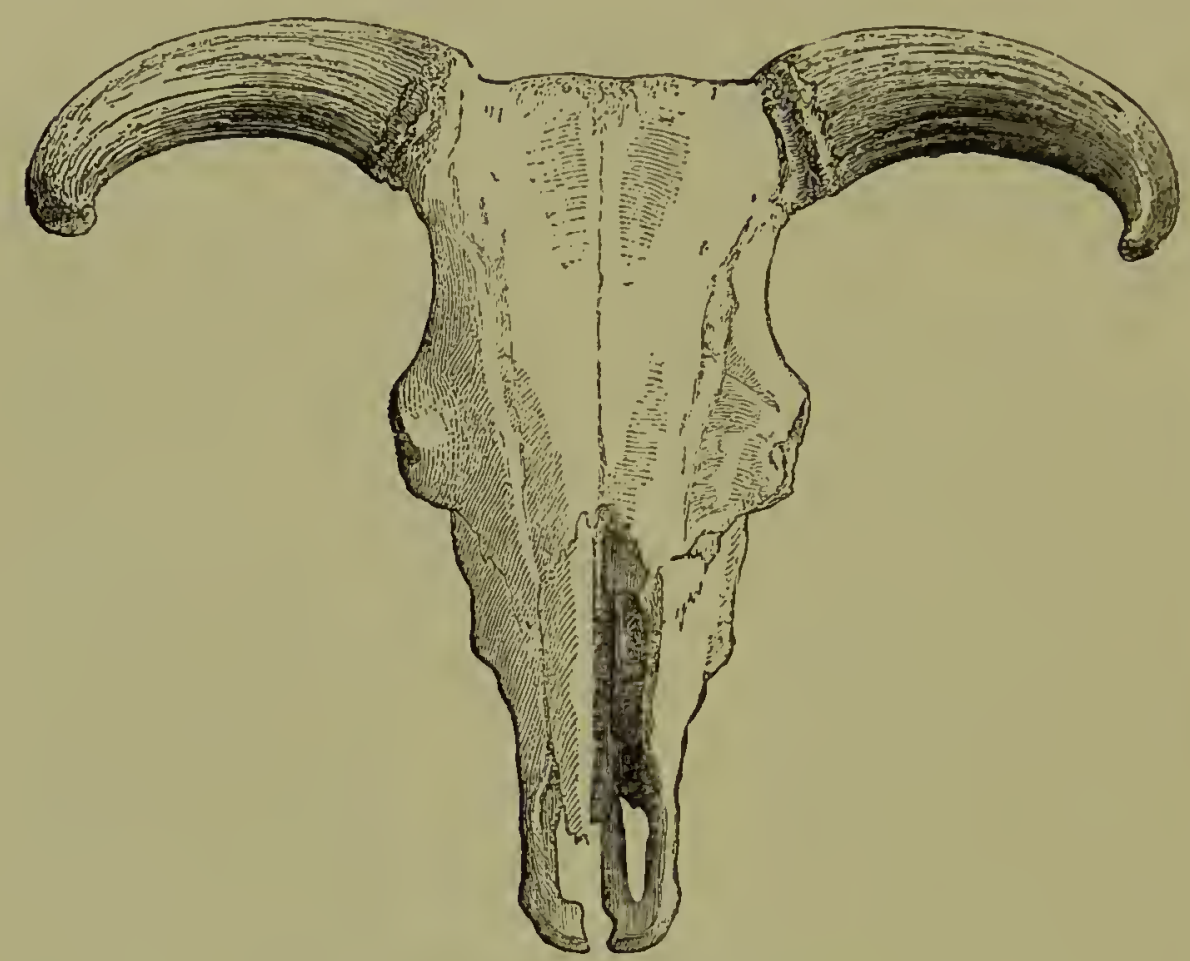

SKULL OF BOS PRIMIGEXIUS, FIFESUILE.

In these and other instances which have been. recorded, the animals whose remains were found were, in all probability, wild, and not domesticated. Indeed, no discoveries have yet been made which lead to the supposition that the Urus was domesticated in. Britain in pre-historic times; while Bos longifrons, the "Celtic short-horn," as it has been termed, was 
everywhere subjugated and used by man. The latter was the only ox in Britain in the time of the Romans, and afforded sustenance to their legions. From it the small dark breeds of Wales and Scotland are descended; and it survived until recently in Cornwall, Cumberland and Westmoreland. The remains of Bos longifrons are plentiful in the English fens, and it seems to have afforded a staple article of

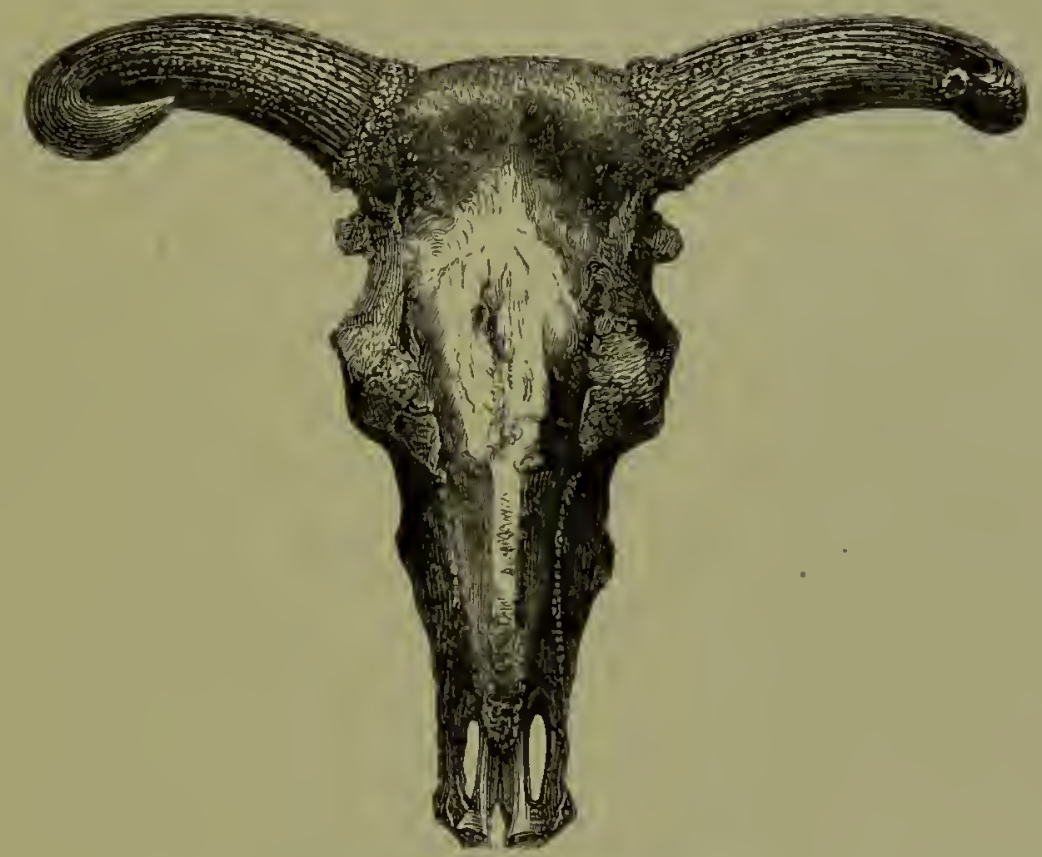

SKULL OF BOS PRIMIGENIUS, LANCASHIRE.

food in the Neolithic Age. Mr. Sydney Skertchley found immense numbers of the bones of this animal in what are probably the remains of a Stone-age lakedwelling at Crowland.* At the great flint-implement manufactory at Grimes Graves, near Brandon, the remains of this animal are very plentiful, and belong chiefly to young calves. It would appear from this

* Miller and Skertchley, "Fcnland, Past and Present," p. 343 $(1878)$. 
that a principal element in the food of these people was milk, and therefore they could not afford to keep the calves, which must have consumed a large portion of what would otherwise have been available for the use of the household.*

But to return to Bos primigenius. While such authorities as Professors Rütimeyer and Nilsson, Sir Charles Lyell, Professor Boyd Dawkins, ${ }^{+}$and Mr. Darwin are inclined to believe that our wild white cattle are descended from the Urus in one or other of the two ways above indicated, Professor Owen and D1: J. A. Smith (whose excellent "Notes on the Ancient Cattle of Scotland" are apparently less known than they deserve to bet) hold a different view, and consider that Bos primigenius became extinct throughout the whole island in pre-historic times. There seems to be much probability, though it can scarcely be considered proved, that such was the case in the southern parts of Britain; but, as Mr. Storer in his lately published work has pointed out, $\S$ it has yet to be showu that in the northern parts the same rule prevailed, the Caledonian deposits especially (partly perhaps from their remote positions) having in but few instances been examined with that consummate skill, care, and attention which southern discoveries have received.

* Greentrell, 'Grimes Graves,' “Journ. Eth. Soc.,"vol. ii. p. 43 I ( 187 I).

$\uparrow$ Professor Boyd Dawkins once thought the Urus might have survived in Britain within historic times in some of the wilder parts of the country, ("Quart. Journ. Geol. Soc.," I 866, p. 397), but subsequently altered his opinion ("Trans. Internat. Congress, Præhist. Arvbrol.," I 868, pp. 269-289.)

+ See "Pro. Soc. Antiq. Scotl.," vol. ix. p. 587.

$\S$ "The Wild White Cattle of Great Britain." 
But our concern is not so much with the origin of the race of wild white cattle, of which a few representative animals still survive, as with the history of the herds which are known to have been preserved in different parts of the country, and of which some half-dozen still exist at the present day. Of these we propose to give some account; but, before doing so, we may glance briefly at the historical notices of the existence of wild cattle in England and Scotland which have been preserved to us in the works of various historians, antiquaries, and naturalists. On looking over the plates of British coins figured by Camden in his "Britannia" (vol. i. p. lxv.) we were struck by a coin of Cunobelin (fig. I3) bearing on the obverse a head of this king, and on the reverse a really characteristic figure, as we take it, of a wild bull-an animal which was no doubt frequently hunted by the early rulers of Britain.

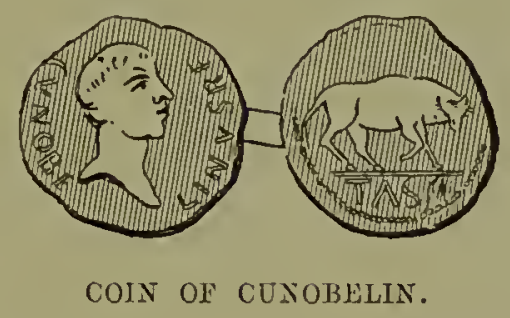

Some indication of the existence of wild cattle in Saxon times is furnished in the celebrated traditionary legend of the slaughter of the wild cow by Guy Earl of Warwick, which is said to have taken place in the days of King Athelstan (A.D. 925-94I). The ballad, "Sir Guy of Warwick," is given in Ritson's "Ancient Songs and 
Ballads," and in Percy's "Reliques of Ancient English Poetry," where we are informed that it was: entered on the Stationers' books in 159I, although undoubtedly of much older date. Much of this story, as Mr. Storer has observed, may be mythical, and many of its circumstances fabulous; but it nevertheless seems to prove just, as clearly the existence in very ancient times of the dangerous and ferocious wild cow, as the popular ballads about Robin Hood prove the existence of fallow deer in Sherwood Forest in the time of King John.*

In the Welsh laws of Howell Dha, which date from about A.D. 940, or before the middle of the roth century, ${ }^{+}$we find white cattle with red ears (that is, resembling in colour the wild cattle of Chillingham) ordered to be paid in compensation for offences committed against the Princes of Wales. It is a question, however, whether the description indicates a difference of breed, or merely a difference of colour in individuals of the ordinary breed of Welsh cattle.

In the forest laws of King Canute (A.D. Ior4-IO35), wild cattle are thus referred to: "There are also a great number of cattle which, although they live within the limits of the forest, and are subject to the charge and care of the middle sort of men,

* Sec also Woods" remarks on this point in his "Description of a Fossil Skull of an Ox found in Wiltshire," 4to, 1839.

$\uparrow$ An English translation of these laws will be found appended to "The Myvyrian Archæology of Wales collected out of Ancient Manuscripts," ed. Owon Jones and others (Denbigh, 1870), pl). roI4-106z. Vide cap. ii. § 3 . 
or' Regardors, nevertheless cannot at all be reputed beasts of the forest as wild horses, bubali, wild cows, and the like."* The word bubati, literally " buffaloes," is considered to mean "wild bulls," being the sense in which it is frequently used by Roman authors.

Speaking of a somewhat later period, Matthew Paris, in his "Lives of the Abbots of St. Aibans," says of Leofstan, abbot in the time of Edward the Confessor, that he cut through the thick roods which extended from the edge of Ciltria (the Chilterns) nearly up to London, smoothed the rough places, built bridges, and levelled the rugged roads, which he made more safe, "for at that time there abounded throughout the whole of Ciltria spacious woods, thick and large, the habitation of numerous and various beasts, wolves, boars, forest bulls (tauri sy(vestres), and stags.

Fitz-Stephen, writing about the year i I74, describes the country beyond London in somewhat similar terms. "Close at hand," he says, "lies an immense forest, woody ranges, hiding-places of wild beasts, of stags, of fallow deer, of boars, and of forest bulls," and he employs the same term (tauri sylvestres) to designate the wild cattle to which he refers. $\dagger$

Nor was this the only part of the country in which these animals were at that time to be found. Knaresborough Forest, for instance, in York-

* See Manwood's "Forest Laws," § 27; Thorpe's "Ancient Laws of Fngland," vol.i. p. 429 ; and Spelman's "Glossary," p. $24 \mathrm{I}$.

† "Vita Sancti Thomx," tom. i. p. 173 (ed. Giles). 
shire, about the year" I 200, had its "fierce wild cattle." **

Speed tells ust that Mand de Breos, in order to appease King John, whom her husband had offended, sent to his queen a present from Brecknockshire of four hundred cows and a bull, all white with red ears. Whether this was the usual colour of the ancient breed of Welsh and British cattle, or a rare viriety, esteemed on account of its beauty, and chiefly preserved in the parks of the nobles, cannot be determined with certainty. It is, perhaps, more natural to suppose that they were all domesticated, and not wild cattle. In later records, however, wild cattle are particularly referred to by this name. "Six wylde bulls," are included in the bill of fare on the occasion of the feast given at the installation of George Nevill, Archbishop of York, in I 466."

Hector Boece(Boethius), who was a contemporary of Leland, and who published his "Scotorum Historix, à prima Gentis Origine," in I 526, has often been quoted to prove the former existence of wild white cattle in Scotland. $\$$ His statement is to the effect that in the great Caledonian wood, which covered a great tract of country, running through Monteith and Strathearn, as far as Athole and Lochaber, there were bulls of the purest white, having manes like lions;

* Walbran, "Memorials of the Abbey of St. Mary of Fountains" (Surtees Society, vol. xliii.).

$\uparrow$ Speed, "History of Great Britaine," folio, I6I I.

+ Leland, "Collectanea" (ed. Hearne), vi., p. 2.

$\$$ This work was translated into the Scottish vernacular by John Bellenden, Archdeacon of Moray, in 1553, and into English by Raphael Holinshed in $\mathrm{I}^{8} \mathrm{~S}_{5}$. 
and, though in other respects they much resembled domestic cattle, they were still so wild and untamable, and so fearful of the approach of man, that they even fled from any grass, trees, or fruit that had been touched by him.

This account has been copied, or at least followed by Paulus Jovius,* Gesner, † Bishop Leslie, Aldrovandus, $§$ Jonston, $\|$ and many other writers much nearer to our own time.

That it was to some extent exaggerated there can be no doubt; and it is not surprising that Sir Robert Sibbald, in his "Scotia Illustrata" ( 1684 ), should have expressed the opinion that it "wanted confirmation." Not that the existence of wild cattle in Scotland was questioned, but only that they presented the appearance which was ascribed to them by Boethius.

From causes readily understood, wild cattle held their ground longer, and continued in a truly wild state later, in Scotland than in any other part of Great Britain. As civilization spread from the south, forests became partly cleared, partly converted into parks, and waste lands were gradually drained and cultivated. Wild animals became either exterminated, like the wolf and the boar, or, like the white cattle, were driven further north to their last strongholds. As the population increased, game

\footnotetext{
* "Descriptio Britanniæ, Scotiæ, Hiberniæ, et Orcadum," I 548.

† " Historia Animalium," I 551 .

+ "De Origine, Moribus, et Rebus Gestis Scotorum, 1578 .

\$ "Quadrupedum Omnium Bisulcorum Historia," I632.

II "Historia Naturalis de Quadrupedibus, I657.
} 
everywhere decreased, except in places where "liberty to inclose" forest land was granted by the king to influential nobles or deserving courtiers. Great tracts of forest were from time to time inclosed within a pale, haye, or wall, with the game and wild animals they contained, or with others driven in, and these inclosures became parks. Thus the land and all that it contained was secured for ever to the person having the liberty to inclose, and no one could thereafter enter or interfere without subjecting limself to severe penalties. *

This was the saving of the wild cattle, which, except for the protection thus afforded them, would, like the other animals mentioned, have become extinct centuries ago.

Many such "licenses to inclose" (some of very early date) are still preserved, and furnish, in not a few instances, a clue to the history of private herds of wild white cattle. In enumerating the herds which are known to us, and concerning which some historical notices are to be found, it will perhaps be convenient to take them alphabetically, those which are still existing being distinguished by an asterisk.

Ardrossan Castle, Avrshire.-Although of unknown origin, it is certain that a herd of white wild cattle, with black ears and muzzles, existed here

* Storer, op. cit. pp. 75, 76. By Stat. Westminster, I. c. 20 , trespassers in parks might be compelled to give treble damages to the party aggrieved, suffer three years' imprisomment, be fined at the King's pleasure, and give surety never to offend in the like kin.l again; and if they could not find $d_{\infty}^{3}$ surety, they had to abjure the realm, or, being fugitive, were outlawed. 
between the years I 750 (when they were introduced by Alexander, tenth Earl of Eglinton) and i 820 , when, on the death of the twelfth earl, Hugh, being much diminished in numbers, they were sent away to be killed. Sir John Sinclair, in I 8 I 4, referred to this herd as one of the few remaining representatives at that time of Caledonia's ancient breed; and Robertson, in his "Description of Cumningham and Ayrshire," published in I820, has given a good description of it. He states that the animals in this herd were pure white, with the muzzle and inside of the ears black, and that they differed from the Chillingham cattle in being polled or hornless; in this respect resembling the herds at Gisburne, Middleton, Somerford, Whalley, and Wollaton. Their number, he adds, was limited, not being allowed. to increase beyond about a dozen; they were thinned by shooting, which required some precaution to accomplish. This account is confirmed by a somewhat similar notice, given by the Rev. Mr: Bryce, minister of Ardrossan, in the "New Statistical Account of Scotland," I 837.

Auchencrurve, Ayrshire.-A little more than a century ago, when this estate, now the property of Mr. Oswald, belonged to the Lords Cathcart, a herd of white wild cattle existed there. In I $76_{3}$ the estate changed hands, and a few years afterwards, within the lifetime of the first Mr. Oswald, who died in 1784 , the cattle, being found troublesome, were got rid of.

Barnard Castle, Durham, formerly part of the 
chase of Marwood, adjoining the great forest of Teesdale, belonged successively to the Baliols (afterwards raised to the Scottish throne), and subsequently to the Beauchamps and the Nevills, Earls of Warwick. By the marriage of the daughter and co-heiress of Richard Nevill, Earl of Warwick, the King-maker, in I47 I, with Richard Duke of Glo'ster, afterwards Richard III., it became the property and favourite residence of that prince until he ascended the throne; at his death it reverted to the Crown. There can be little doubt that during the whole of this period wild cattle existed and were hunted here, for they still existed here 150 years later. Charles I., by a grant dated March 14, 1626, in consideration of a considerable sum of money, granted to Sumuel Cordwell and Henry Dingley, in trust for Sir Henry Vane, the reversion of Barnard Castle, with its parks, "together with all deer and wild cattle in the said parks."* It is believed that wild cattle also existed at one time at Raby Castle, about six miles distant, the seat of the Duke of Cleveland.

Bishop Auckland, Durham, originally part of Weardale Forest, belonged to the Bishops of Durham, who kept wild cattle here before the Reformation. Leland describes it as "a faire parke by the castelle, having fallow deer, wilde bulles, and kin." In 1338 it was let to Sir R. de Maners, from which it may be inferred, says Raine, $\uparrow$ that the deer and wild cattle,

* Hutchinson, "Hist. Durham," vol. iii. p. 245.

+ "Historical Account of the Episcopal Palace of Auckland," pp. 77,79 . 
not mentioned until afterwards, were then either few in number or none at all. "Wild kyne, with calves and bulles, \&c., of all sortes, remayned in Auckland Parke, Sept. 24, 1627, the number thirty-two" (Raine, p. 77).

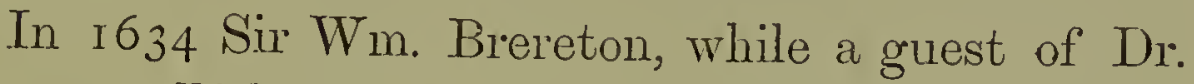
Moreton, Bishop of Durham, at Bishoppe Auckland, thus described the cattle he saw: "A daintie stately parke; wherein I saw wild bulls and kine which had two calves and ruñers; there are about twenty wild beasts all white; will not endure $\mathrm{yo}^{r}$ approach, butt if they be enraged or distressed, very violent and furious: their calves will bee wondrous fatt." These cattle appear to have been all destroyed during the civil wars of Charles I.'s time. In the Parliamentary Survey of March 22, I 646-7, this park is described, and it is said "the deere and gameviz., fallow-deere and wilde bulls, or bisons-utterly destroyed, except two or three of the said bisons, and some few conies, in that part of the park called 'the Flaggs,' under the said walls of the said castle or palace." Stainwick Park, also in the county of Durham, the property of the Duke of Northumberland, is believed at one time to have held a herd of wild white cattle, while there is good reason for supposing that other herds existed at Raby Castle, the

* This description is quoted by Raine in his " Historical Account of the Episcopal Castle or Palace of Auckland" (p. 79), from a MS. in the possession of Sir Philip Grey Egerton, entitled "The Second Yeare's Travell throw Scotland and Ireland, 1635." This MIS. has been printed by Sir Philip Grey Egerton, Ann. Mag. Nat. Hist., vol, ii. Prblications, 1844 . 
principal seat of the Nevills, and at Beaurepaire, the ancient hunting park of the Prior's of Durham. The cattle at this last-named place, it is said, were all destroyed by the Scots in I 3 I 5 .

Blamr Atrotem, Perthshre.--Fifty years ago, in one of the parks of this ancient seat of the Murrays, Dukes of Athole, in the forest of that name, roaned a herd of wild cattle, white with black points, having the ears, muzzles, and hoofs black. In 1834 this herd was sold, a portion going to Taymouth to the Marquis of Breadalbane, and the remainder to Dalkeith, to the Duke of Buccleuch. Both these herds are now extinct, but from them has descended in part the semi-wild herd which still exists at Kilmory House, Argyllshire, the property of Sir John Powlett Orde.

Burton Constable, Yorkshire, an ancient park, at present containing about 290 acres, is the property of Sir F. Clifford Constable. At one time it contained a herd of white cattle, as we learn from Bewick, who in I 790 wrote of them as having becn then a few years extinct. "Those at Burton Constable," he says, "were all destroyed by a distemper" a few years since. They varied slightly from those at Chillingham, having black ears and muzzles, and the tips of their tails of the same colour. They were also much larger, many of them weighing sixty stone, probably owing to the richness of the pasturage in Holdemess, but generally attributed to the difference of kind between those with black and white red ears, the former of which they studiously endeavour to preserve. The origin of this herd has only been surmised.* * See Storer. p. 255. 
*CAdzow Cas'tue, Lanarkshire, the seat of the Duke of Hamilton, with its park, originally formed part of the great Caledonian Forest, wherein King Robert Bruce, according to tradition, hunted the wild bull in 1320 , and where, two centuries later (namely in I 500), James IV. of Scotland indulged in the same wild sport. This park has from time immemorial contained a herd of wild white cattle, which has been frequently described, and which still exists.* Sir Walter Scott has immortalized these cattle in his ballad of "Cadyow Castle":-

"Mightiest of all the beasts of chase

That roam in woody Caledon,

Crashing the forest in his race,

The mountain bull comes thundering on.

"Fierce, on the hunter's quiver'd hand,

He rolls his eyes of swarthy glow,

Spurns with black hoof and horn the sand, And tosses high his mane of snow."

He is in error, however, when he states that the Cadzow cattle were extirpated for their ferocity about I 769.' In all probability he derived this impression from a statement to that effect in the "Old Statistical Account of Scotland," vol. i. p. I 80 ; ii. 208.

As compared with those kept at Chillingham, the animals in this herd differ in having the inside of the ears black instead of red, and the fore part of the

* One of the best accounts of this herd is that published by Jesse, who received it from a $\mathrm{M}_{1}$. Brown, chamberlain to the Duke of Hamilton.

† "lay of the Last Minstrel," 8vo, i8og, notes, p. 40. See also Stuart's "Lay of the Deer Forest," vol. ii. p. 225. 
leg, from the knee downwards, mottled with black. The cows seldom have horns; their bodies are thick and short, their limbs stouter, and their heads rounder than in the Chillingham breed, with small turn-up horns. In October, 1874, there were about thirty animals in this park, including one bull, and in a field near the park with similar pasturage were fifteen bulls and steers, along with one old cow and a young heifer-in all forty-five head. In June, 1877, the number had increased to fifty-six.*

* Chartley Park, Staffordshire, nearly iooo acres in extent, the property of Earl Ferrers, was formed by inclosing part of the Forest of Needwood by charter of Henry III. "About this time (32, 33 Hen. III., that is, I 248-9)," says Sir Oswald Mosley, "some of the wild cattle of the country which had hitherto roamed at large in the Forest of Needwood were driven into the park at this place, where their breed is still preserved." $†$ Erdeswick, who began his "Survey of Staffordshire" about 1593, speaks of it as very large, and having therein red-deer, fallowdeer, wild beasts (i.e., cattle) and swine. In an old "Account Book of the Steward of the Manor of Chartley, Præses, Com. Ferrers," is the following entry:

" 1658 . Pd a moytie of the charge of mowings, makings, and carrying of hay for ye wild beasts $-£ 27 s .7 d . "$

In this herd, the usual average number of cattle, which were white with black ears, is said not to have

* A. H. Cocks, The Zoologist, 1878, p. 283.

† "Hist. 'L'utbury, co. Stafford" (1832). 
exceeded thirty; yet in April, I $85 \mathrm{I}$, according to Mr. E. P. Shirley, there were forty-eight, and in 1873 there were twenty-seren. In July, I 874, Mr. Storer found only twenty-five-namely, ten breeding cows, four bulls (two adult), six steers, and five heifers, of various ages; the finest old bull and one of the cows, besides some calves, having died since the previous autumn. In June, 1877 , when $\mathrm{Mr}$. A. H. Cocks visited this park, as described by him in The

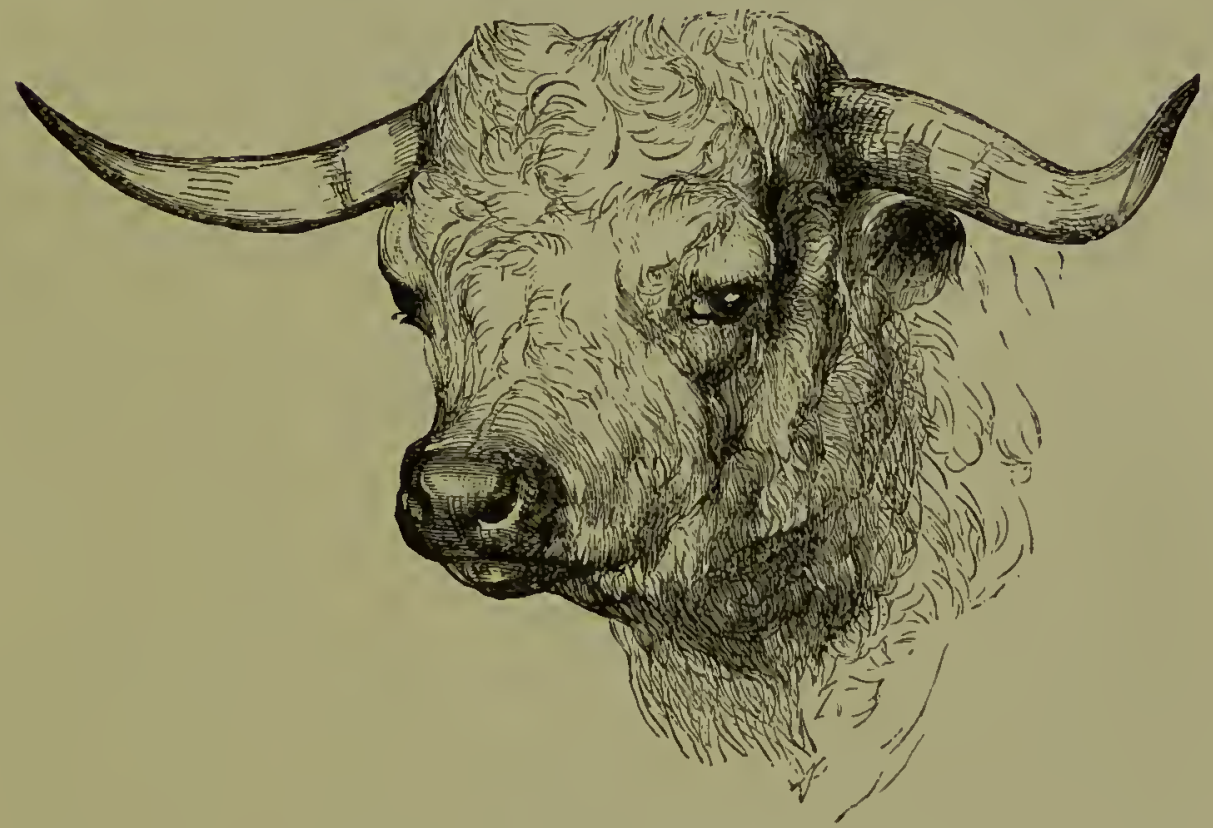

WILD BULL OF CHARZLEY.

Zoologist (1878, p. 276), the herd, consisting of twenty animals, was thus constituted: One nineyear-old bull, one five-year-old bull, one bullock, five or six young bulls of different ages, two young bull calves (one called two months old, the other two or three weeks), the remaining nine or ten being corws and heifers of various ages.

In appearance the Chartley cattle-independently 
of the different colour of the ear's, which are black instead of red-ire very unlike those at Chillingham.* They are, in fact, "long-horns." Nor are they so wild as the Northumberland herd. Mr. Storer has suggested that this is probably owing to the circumstance that the park is bounded on one side by a public road, from which it is only separated by a paled fence, which is not the case at Chillingham, so that they are at Chartley much more habituated to the sight of man.

* Childingham Castue, Northumberland, the seat of the Earl of Tankerville, has been oftener visited, and oftener written about, than any other park containing wild cattle, and is, therefore, better known to the reading public. Of the date of the inclosure of this park (originally I 500 acres; now, exclusive of woods, about I 100) no record has been found; but there is evidence of its existence in $\mathrm{I} 292, \dagger$ and "a park with wild animals" is referred to in an inquisition 42 Edward III., as "of no value beyond the maintenance of the wild animals." The "great wood" of Chillingham is referred to in a document of I 220.f Mr. Darwin seems to have thought that this referred to the park, since he regards the date above mentioned as that of its inclosure. $\$$ This, however; is not proved by the document in question. At the same time it is not at all unlikely that the inclosure

* See Plot, "Nat. Hist. Staffordshire," 1686, pl. 5; and Shaw "Hist. and Antiq. Stafford," I798.

† See Tate's " History of Alnwick," vol. i. p. 94.

‡ Hindmarsh, "Ann. Nat. Hist.," vol. ii. p. 274.

\$ "Animals and Plants under Domestication," vol. i. p. 8r. 
took place about that time (temp. Hen. III.), and that the cattle were then driven in, just as they were at Hamilton, Drumlanrig, and Naworth, all of which herds, together with that at Chillingham, were probably detachments from the main body of wild

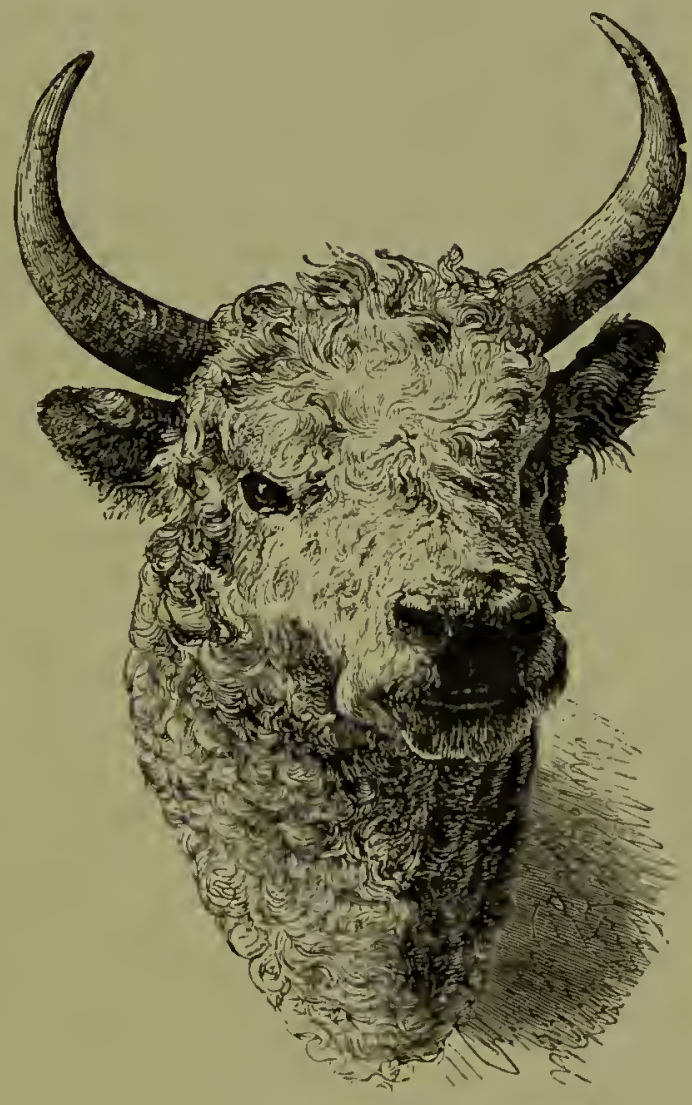

WHLJ BULL OF CIILLINGIAJ.**

cattle which formerly roamed the Caledonian Wood. Mr. Storer says :

"Whatever may be the age of the park, that, I imagine, indicates also the time when the wild cattle were first confined within its boundaries, for no record of their introduction exists. I suppose that they, previously wild denizens of the surrounding

* For these two illustrations from Mr. Storer"s work we are indebted to the courtesy of Messrs. Cassell, Petter and Galpin. 'I'he horms of the Lyme Park herd are of an intermediate character between these two. 
forest, were then first incarcerated, as they were at Chartley and at Lyme."**

It is at least certain that this herd was in existence two centuries ago. In Mackenzie's "View of the County of Northumberland" (1825) there is the following note (vol. i. p. 390) :

"In a family aceount book, written by Willium 'l'aylor, steward of Chillingham, and now (182I) in the possession of his great-grandson, William Taylor, Esq., Hendon Grange, near Sunderland, is an outlay :

" 1689, Dee. 5, pd Wn. Kadyll's white ealf ten shillings.

"May 1692. Beasts in the Parke. My lorde's I6 white wilde beasts. 2 black steers and a guy, 12 white, read and black ear'd, 5 blacke oxen and brown one, 2 oxen from Warke, from last a steer liilled.

"August "92. Ye guy had a ealfe, and went to Upwarke with the twelve black and read-ear'd, two of the Warke, and the brown one at Chivton."

Many accounts of this herd have been published from time to time, amongst which we may refer to those of Pennant, Cully, Bewick, Lord Tankerville, Hindmarsh, and quite recently those of Mr. A. H. Cocks and the Rev. John Storer, all of whom have written from personal observation.

The account given by the late Lord Tankerville ("Ann. Nat. Hist." vol. ii.) commands perhaps the chiefest attention, since it comes from a former

* Chatton, adjoining Chillingham, imparked by Edward I. in I2911292, contained "wild animals," presumably the same as those at Chillingham.

† This word, which is variously spellerl "quhy," "whye," "why," "wye," and "twy," appears to be an alubreviation of "twynters" (two winters), and signifies a two-year-old heifer. In the Accounts of the Bursar of the Monastery of Durham, 1530-1534, commonly called "The Durham Househola Book" (pp. 205, 30r, 327), are the following entries:-

"Et in 2 twynters (whyes) et 2 twynters (whyes) emptis de Wilhelmo Bernarde@9s............ . 36s.

Et in 4 vaecis, vocatis whyes emptis de Willelmo Bernarde, hoe anno 9 (1) . . . . . . . . . . $36 s_{\text {. }}$ 
owner of the herd, who naturally would be expected. to know more about it than any visitor.

In I692, according to the steward's account, the herd consisted of only i 4 breeding animals, bulls, and cows, and calves of both sexes, and 12 steers; in all 28. Tn I 838, according to $\mathrm{Mr}$. Hindmarsh, there were about 8o, comprising 25 bulls, 40 cows, and I 5 steers of various ages. In May, I 86 I, Mr. Darwin was informed by the agent, Mr. Hardy, that they numbered about 50. This was about the number we saw when visiting the park in May, I863. In August, I 873, the herd consisted of 64 head-I 7 bulls of all ages from calves upwards, 19 steers, and 28 cows, heifers, and female calves (Storer, p. I7 I). In October, I874, according to Lord Tankerville, the herd numbered 7 I. In March, I 875, the number had again decreased, amounting to 62 only-viz., i 4 bulls and bull calves, 3 I corvs and cow calves, and I 7 steers. In July, i 877 , there were still fewer-59 only - consisting of 8 bulls, 27 cows and heifers, and i 6 steers (Zoologist, I878, p. 281). Lord Tankerville says they increase slowly, several dying each year by accidents or by overrunning their calves when disturbed; and the cows breed slowly, owing to having fiequently the calves still sucking the second year."

Bewick's assertion that a few of the Chillingham cattle in his day had black ears is confirmed from other sources. In 1692 there were more with black ears than with red ears, and the present prevalence of red ears seems to have been brought about by selection.

Drumlanrig Castle, Dumfriesshire.-Until the 
close of the last century there was a herd of white wild cattle here, the property of the Juke of Queensberry. Its origin is unknown, but it appears to have been of some intiquity. Pennant (who went to see these cattle) and Bewick, who has noticod them, describe them as white with black ears. According to Mr. Hindmarsh, who derived his information from the clergyman of the place, "they were driven away about I 780" by the fourth and last Duke of Queensberry. Other writers besides those named have identified the animals in this herd with " the wild Caledonian cattle."

Ewelme Park, Oxfordshire, formerly belonging to the De la Poles, Dukes of Suffolk, once contained a herd of wild cattle. In I 536 Edward Ashfield was appointed by Henry VIII. "kceper of the Park of" Ewelme and master of the wild beasts there. In I 606 Lord William Knollys was keeper of the park and master of the wild beasts in the same" for James - I. That the term of "xvild beasts" referred to wild cattle, and not to any of the other wild animals which James I. delighteth to keep, is shown by a reference to the hay which was provided for them, which occurs in the conveyance of the park by Charles I. to Sir Christopher Nevil and Sir Edmund Sawyer in 1627 .*

Gisburne Park, Yorkshire, the seat of Lord Ribblesdale, is situated in the district of Craven, in the West Riding. It once formed part of Gisburne

* Napier's "Historical Notices of Swyncombe and Ewelme," I $\$_{3} 8$, pp. 204, 207, 212, 217; Shirley, "Engiish Decr Parks," p. 137. 
Forest, while the still more extensive forests of Bowland and Blackburnshire were closely contiguous. So far as can now be ascertained, it appears tolerably certain that this herd, seldom numbering more than eight or ten head, was once part of the herd at Whalley Abbey, the property of the Asshetons, and that in 1697 , on the death of Sir John Assheton, the last baronet of Whalley Abbey, part of the herd there went to Gisburne, to the Listers (afterwards Lords Ribblesdale), * with whom the Asshetons were connected by marriage: and the other part was added to the previously existing herd at Middleton Park, belonging to his heirs, the Asshetons, baronets of Middleton. In I790 Berwick wrote:-At "Gisburne there are some perfectly white, except the inside of the ears, which are brown. They are without horns, very strong boned, but not high. They are said to have been originally brought from Whalley Abbey, in Lancashire, upon its dissolution in the twenty. third year of Henry VIII., and to have been drawn to Gisburne by the porver of music"-in the same way that a herd of about twenty Red-deer is said to have been brought out of Yorkshire to Hampton Court.t

A few years later, Dr. Whitaker, in his "History and Antiquities of the Deanery of Craven," published in I 8 I2, gave the following account of them, with portraits of a bull and cow (pls. 8 and 9, p. 37) and a view of the park (pl. Io).

* The grandson of Thomas Lister (to whom Sir John Asheton had bequeathed Gislurne and part of the Whalley herd) and Catherine A sheton of Middleton, was created Baron Ribblesdale in 1797 .

+ I'layford's "Brief Introduction to the Skill of Music," 1655. 
"Gisburne Park is chiefly remarkable for a herd of wild cattle, descendants of that indigenous race which once peopled the great forests of Lancashire. After their extinction in a wild state-which we know did not take place till a short time betore the age of Leland-it is highly probable that the breed was kept up by the Abbots of Whalley in the 'Lords Park,' and fell into the hands of the Asshetons, who acquired possession of that rich domain after the Dissolution. This species differs from those of Lyme in Cheshire, and Chillingham Castle in Northumberland-where alone in South Britain they are now preserved-in being without horns.

"They are white, save the tips of their noses, which are black; * rather mischievous, especially when guarding their young, and approach the object of their resentment in a very insidious manner. They breed with tame cattle ; $\uparrow$ but it is to be hoped that respect for so ancient and singular a family will induce the noble owner to preserve them from any foreign admixtures."

They became extinct in 1859 , having become so delicate from breeding in-and-in, that their owneris coula no longer keep them. They had become quite tame, and were housed in winter. The last cow and calf were sold to Mr. Legh, of Lyme Park, in October,

* A copy of the "History of Craven" in the library at Gisburne Park has the following note opposite the statement that the noses were black, in the handwriting of the first Lord Ribblesdale: "the ears and noses of this species of eattle are never black, but most usually red or brown."

+ This attempt to cross the breed failed, as did a similar attempt which was made by bringing a heifer from Lyme to Gisburne. 
I 859 , and on the Ioth of November in that year the bull, the last of his race, was killed.

Hoghton Tower, Lancashire, the park whereof once formed part of the forest of Bowland, had a very ancient herd of wild cattle, which has been extinct probably about two hundred years.

Holdenby Park, Northamptonshire, was licensed to be imparked in I578, and was much enlarged when James I. purchased the estate of Sir Christopher Hatton in I607 (Pell Records, p. So). During the Civil War Holdenby was seized, and granted by the Parliament to Thomas Lord Grey of Groby, who sold it to Adam Baynes, of Knowsthorp, Yorkshire, who in I 650 destroyed the park and pulled down the mansion. At the time of the sale, the park of 500 acres was stocked with upwards of two hundred deer of different kinds, worth $£ 200$, and eleven cows, and calves of wild cattle, worth $£ 42$.* Mr. Storer thinks they were introduced by James I.

* Kilmory House, Argyllshire. See Buair AтноLе, whence this herd was derived.

Leigh Court, Somersetshire.-This park, which once contained a herd of wild cattle, formerly belonged to the Augustinian Canons of Bristol, and was beautifully wooded. It is now the property of Sir William Miles, Bart., whose father in I 808 purchased it from the heirs of Lady Norton. Two years previously-i.c., in I806--the wild cattle there had become so savage that the owner was obliged to have

" Baker, " History of Northamptonshire," vol. i. p. 197. 
them shot." There is no clue to their origin, and this is the only instance yet known of a wild herd in the west of England.

*Lyme Park, Cheshire, was originally part of the Forest of Macclesfield, and was granted by Richard II. toward the close of the fourteenth century to Sir Piers Legh, who was standard-bearer to the Black Prince at the Buttle of Cresci. It has ever since remained in the family of Legh, and the breed of cattle still preserved there is thought to be at least as ancient as the park itself. Hansall, in his "History of Cheshire" (18 I 7), says :

"In Lyme Park, which contains about one thousand Cheshire acres, is a herd of upwards of twenty wild cattle, similar to those in Lord Tankerville's park at Chillingham-chiefly white with red ears. They have been in the park from time immemorial, and tradition says they are indigenous. In the summer season they assemble in the high lands, and in the winter they shelter in the park woods. They were formerly fed with holly branches, with which trees the park abounded; but these being destroyed, hay is now substituted. Two of the cows are shot annually for beef."

Thirty years ago this herd, it is said, numbered as many as thirty-four head. Then it gradually dwindled until in August, I 875, when Mr. Storer visited Lyme, there were only four animals surviving -a three-year-old bull, a cow, a three-year-old heifer in calf, and a young calf. In two years' time there * Shirley, "English Decr Parks," p. 99. 
was a slight increase, for in June, i $877, \mathrm{Mr}$. A. H. Cocks found two bulls, two cows, and two heifers, although one of the cows unfortunately was particoloured.

The loss of two cows during the present owner's time, and impairment of the fertility of others by the foot-and-mouth disease, as well as the retention at one time of a single bull which proved infertile, are the chief causes which have led to the threatened extinction of the lierd, added to which Mr. Legh attributes its present diminished numbers to long-continued in-and-in breening from near affinities.

Although in habits the old Lyme cattle resembled those at Chillingham, they were larger than any breed of cattle now existing in this country-higher on the leg, more upstanding, and longer in the body - very large cattle, with strong bone, much substance, and a large amount of flesh about the neck and dewlap. They had abundance of long rough hair, which, in the males was very fully developed, curly and mane-like on the head and fore-quarters, and the hide was of immense thickness. They were very grand and symmetrical in appearance, and their movements were distinguished by a peculiar majestic stateliness. Their flesh was excellent, but there does not seem to have been any record kept of their weights. For a great many years, indeed, none but cows were ever slaughtered, and latterly not even these. The colour of the ears is subject to variation, and, although generally red, it is sometimes black or 
blue approaching to black. 'The horns are of an intermediate character between those of the Chillingham and Chartley breeds.

Mrddieton Park, Lancasume, the ancient seat of the Asshetons, was originally part of the great forest of Bowland, whence possibly the ancestors of the herd of white cattle which existed here were driven in on the inclosure of the park. At Blakeley (about a mile from Middleton Hall), says Leland, "wild bores, bulles, and falcons bredde in times paste."** Tradition, however, affirms that the Middleton herd originally came from Whalley Abbey, and the family connection which existed between the Asshetons of Middleton, the Asshetons of Whalley, and the Listers of Gisburne renders it, in the rords of Mr. Assheton, "highly probable that had sither" family by any means acquired the wild cattle, they were very likely to have spread from them to the others." The cattle in this herd were white and polled; some had black, others brown ears. Dr. Leigh, in his "Natural History of Lancashire, Cheshire, and the Peak of Derbyshire" (book ii. p. 3), published in 1700 , thus alludes to them: "In a park near Bury in Lancashire are wild cattel belonging to Sir Ralph Ashton, of Middleton; these, I presume, were first brought from the Highlands of Scotland [a mere surmise, probably founded on his acquaintance with the accounts given by Boethius and Leslie of the Caledonian bull]. They have no horns, but are like the wild bulls and cows upon the continent of America :"

$$
\text { * Leland, "Itin.," rol. vii. p. } 47 \text { (ed. Hearne). }
$$


from which we may infer that in Dr. Leigh's day the bulls showed some indication of a mane. The descendints of this herd are not yet entirely extinct, although they have become quite domesticated; for, on the death of the third baronet in I 765 , when the baronetcy became extinct, the elder of his two daughters, co-heiresses, married Sir Harbord Harbord (afterwards, in I 780 , created first Lord Suffield), and inherited Middleton and the wild cattle, which were then removed to Gunton Park, Lord Suffield's place in Norfolk. Here they were preserved for many years, but gradually declined, until on the death of the fourth Lord Suffield, in 1853 , they ceased to exist there. In the meantime, however, some had been transferred to Blickling Hall, originally the property of the Hobarts, created Earls of Buckinghamshire in 1746 , and eventually inherited by the Hon. William Assheton Harbord (eldest son of the first Lord Suffield) on his marriage with one of the three daughters of the second Earl of Buckinghamshire, who died in I 793 without male issue. Other's were sold about 1840 to Mr. Cator, of Woodbastwick Hall, near Norrwich, but, being subsequently crossed with shorthorns, the character and colour of the survivor's have become much altered, although, as remarked by the Rev. Mr. Gilbert, who visited this herd in November, I875, "there is a perpetual struggle at Woodbastwick to reproduce the original type: and this proves low much more firmly fixed is this in the blood than is that of any of the recently introduced crosses." 
Naworth Casthe, Cumberland.-It appear's fiom the "Household Book" of Lord William Howard, of Naworth, commencel in IGI2, that wild cattle were introduced into this park in I629, from Martindale Forest, in the neighbourhood of 'Thornthwaite, where at that time probably they roamed in a state of nature.* The entry is as follows:

1629. Januari 9. To Anthonie Bearper George Bell \& William Halle for their charges and paines in briuginge wilde eattell from Thornthwate- $-\nabla s$, iiijd.

The date of their introduction at Naworth is thus approximately fixed. $\dagger$

The "hirde of the forest" at this time was Richard Fisher, whose wages were $£ 8$ a year, paid half-yearly in May and November. When any of the wild cattle here were killed, the skins were sold with those of other oxen, but apparently did not fetch so much. Thus (at p. 284) we find the entry:

1633. June 22. Rec. for 2 kine skinns-xiijs.

Rec. more of him [i.e. the purchaser, Wm. Buckle] for one wild lowe skine-iiijs.

The calves were sometimes killed for the table, and being considered a delicacy, were sent as presents like game and wildfowl. Thus (at p. 3 I 8 ) an entry runs :

1633. Aug. 23. To Mr. Thomas Howarde's manne bringinge one quarter of a wilde calfe to my Ladie- $\nabla s$.

The cattle in this park, however, did not remain there many years. In 1675 it appears they had

* This "Household Book," edited by the Rev. George Ornsby for the Surtees Society, seems to have eseaped the notice of Mr. Storer.

t 'The park at Naworth was then enclosed by a wall, as we gather. from entries of payments for repairing it (c.g. p. 320). 
ceased to exist, having been destroyed probably during the Parliamentary wars.

In a MS. and anonymous "Description of Cumberland," dated I675, and said to have been written by Edmund Sandford, a gentleman of good family in the county, the writer, describing Naworth Castle and the neighbourhood, says that around it formerly were "pleasant woods and gardens; ground full of fallow dear feeding on all somer tyme; braue venison pasties, and great store of reed dear on the mountains, and white wild cattel with black ear's only, on the moores; and black heath-cockes and brone more-cockes, and their pootes."*

* Somerford Park, Cheshire, the property of Sir Charles Shakerley, is situate near Congleton, in the heart of what was once Maxwell Forest. ${ }^{\dagger}$ An ancient herd of white cattle, resembling those at Chartley, but polled, still exists here; and these animals are considered to be the best surviving representatives of the hornless and tame variety of the original wild white breed. The colour is pure white; the ears, rims of the eyes, muzzle, and hoofs being quite black. Like all other old herds of the forest breed, they have a strong tendency to produce small black spots on the neck, sides, and legs, and this the proprietors admire and encourage; many of them have therefore become more or less speckled. When Mr. St.orer visited this herd in August, I 875, it numbered twenty head. It is to be regretted that no record or even

* Jefferson, "Hist. and Antiq. Carlisle" (1838), p. 36 r.

† Leland, "Itinerary," vol. v. p. 87 (ed. Hearne). 
tradition with regard to the origin of this herd exists ; for its appearance, according to Mr. Storer, bespeaks great antiquity. In answer to inquiries on the sulject, the present owner, Sir Charles Shakerley, leplied: "We have no history of how they came, or" how long they have been here. I. am of the third generation which has known nothing about thein. 'The tradition is, they have been here two liundred vears." It is quite possible that, like those at Lyme and Chartley, they may have been originally wild in the adjacent forest, and were driven in to the park when it was first inclosed. On the other hand, being of the same race as those at Middleton, they may have come originally from Shakerley, only a few miles distant from Middleton and Blakeley.

Whalley ABBey, Lancashire, had a park attached, which was originally part of the Forest of Bowland (granted by Edward VI. to a branch of the family of Assheton), and until r697 contained a herd of white wild cattle, which were polled. Some of these, according to tradition, were in that year sent to Gisburne Park, as above mentioned, where they existed until I 859 ; the remainder being transferred to Middleton Hall, where, after the death of the fourth Lord of Sheffield in 1853, they were no Ionger preselved.

Wollaton Park, Notwinghamshire, belonging to the family of Willoughby, Baron Middleton, was formerly part of Sherwood Forest, and held white cattle until about fifty years ago.* In I 790 Bewick

* See Thoroton, "Antiquities of Nottinghamshire," $1677,11.7$, and Throsby's edition of this work, I790, rol. ii. p. 214, pl. 27. 
mentioned this herd as one of the five "only breeds now remaining in the kingdom." 'They were all white, with black noses and black ear's, and had a fine circlet of black round the eyes. They were polled, or hornless, and were known as the "old park breed," a name denoting some antiquity. Their origin can now only be surmised. * They became extinct in the time of Henry, sixth Lord Middleton-that is, between 1800 and 1835 -when, fourteen of them having died at one time from eating dead branches cut from trees near the hall, and the herd having thus become so reduced by the accident, and the survivors showing no tendency to breed, they were ordered to be sold and slaughtered.

Of all these herds, there are now existing only those at Cadzow (Hamilton), Chartley, Chillingham, Kilmory, Lyme, and Somerford.

In Ireland no trace of these wild cattle lias yet been discovered, although remains of the smaller Bos longifrons have been procured from many Irish localities. ${ }^{+}$

* Storer, pp. 274,275 .

† See Ball, "Proc. Roy. Irish Acad.," vol. ii. p. 541; Wilke, op. cit., vii. p. I83. Adlams, op. cit. (second series), vol. iii. p. 90 ; Scouler, "Journ. Geol. Soc.," Dublin, vol. i. p. 228; Owen, "British Fossil Mam mals," p. 508 ; and Thompson, "Nat. Hist. Irelaud," vol. iv. p. 35. 



\section{IN D EX.}

Accidexts at Bear-baiting, 26, 3 I

Advertisements of Bear-baiting, 30

Alfric, Colloquy of, 79

Ambrose, "Roast Wolf," I 52

Annales Cambrice, I 37

Antlers of Reindeer, 7 I, 75

Asser's "Life of Alfred the Great," I 22

Aubrey, "Natural History of Wiltshire," 94, 95

BEAR, remains of, I I

" in Manea Fen, 12

" at, St. Bride's Bay, I2

", in Kent's Cavern, 12

", in the Victoria Care, I2

", at Colchester, 13

", at Richmond, Yorkshire, I 3

, in Dumfricsshire, I 3

$\because \quad$ in Ireland, I $3-16$

" in Wales, 17

" a benst of chase, 17

", its flesh esteemed, I7

" mode of lunuting, 18

", iu Saxon times, 19, 20

" with the Romans, 2 I

", trinsported from Britain to Rome, 2 I, 22

B ars, Caledonian, 2 I

" traditions of, in the Highlands, 23

., $\quad$ in Ircland, 23

"date of extinction in Britain, $2+$

luear-baiting, 25

", accidents at, 26, 3I

" advertiscments of, 30

" garden, 32

Bcar-wards, $20^{\circ}$ 
Bears, Chief Master of the, 27

" of the Farl of Northumberland, 28

, of the Prior of 1 ) urham, 28.

\section{Beaver, 33}

, in Wrales, 34

, Welsh name for, 37

" mentioned in Welsh laws, 33

" $\quad$ " by Giraldus Cambrensis, 35

, , by Tarrison, 35-36

, . $\quad$, by Drayton, 36

.. $\quad$ ". by Camden, 36

.. $\quad$ " by Sir R. C. Hoare, 36

,. , by Owen in Welsh Dictionary. 37

, $\quad$ " by Sir John Price, 38

Beaver's in Scotland, 40 by Inmphrey Llwyd, 38

," mentioned by Boethius, 40

. $\quad$, $\quad$ Bellender, 40

Beaver, Gaelic name for, 41

Sir R. Siblald, 40

., diseovery of remains of, 42

, in Perthshire, 42

" in Berwickshire, 42

, in Roxburghshire, 42

, in Norfolk, 42

, in Suffolk, 42

.. in Berkshire, 42

, in Kent, 42

" in Cambridgeshire, 43

,$\quad$ in Hampshire, $4 j$

., in Lineolnshire, 45

.. in Devonshire, 45

, in Isle of Bute, 46-59

Beaver skin, value of, 34

Beverley, derivation of name, 46

Beverege, 46

Bevere Island, 46

Beverburn, 46

Bevercotes, 46

Beverstone, 46

Beversbrook, 46

Bedd-gelert, story of, 1 to

Belle Saurage, the, 26

Berners, Dame Juliana, I jo

Bernwood, Forest of, so

Boar, Wild, see Wild Bonr

Boar's chase, the, 90 
Boar-frank, 96

Boar's head, eustom of bringing in, I I I

, in Easteheap, I I I, I 12

$"$ in Southwark, 114

Boar-hunt, in Eskdale, 83

Boar-spears, 84,85 , I I 4

Boar, the, of Borestall, 8i

Bolton Priory, aecounts of, $14+$

Book of St. Albans, I 50

" of Howth, 187

" of Information, I9I

", of Rights of the Kings of Eriu, 93

Boyd Dawlins, Prof. W., on remains of Bear, 12

" " " Reindeer, 62, 74; on Wolf, I 8

Bos primigenius, skull of, 216, 217

Bowland Forest, 7, 8, I I 9, I 55

Brochs, or ancient cireular forts, 70

Burial Places, insular, as protection from Wolves, 182

Browne, Sir Thomas, on errors eoncerning TVolves, $2 \mathrm{O}_{4}$

Catus, de Canibus, I3I

Caledonian Forest, 9, 21, 160

Uampbell of Glen Urcha, 172

Canes Scotici, 22

Cannock Chace, 6

Canute, forest laws of, I 32, 220

Carmen de Bello Hastingcnsi, 133

Carte, Dr., o:1 Irish Fossil Mammals, 14, 66

Cattle, Wild, 213

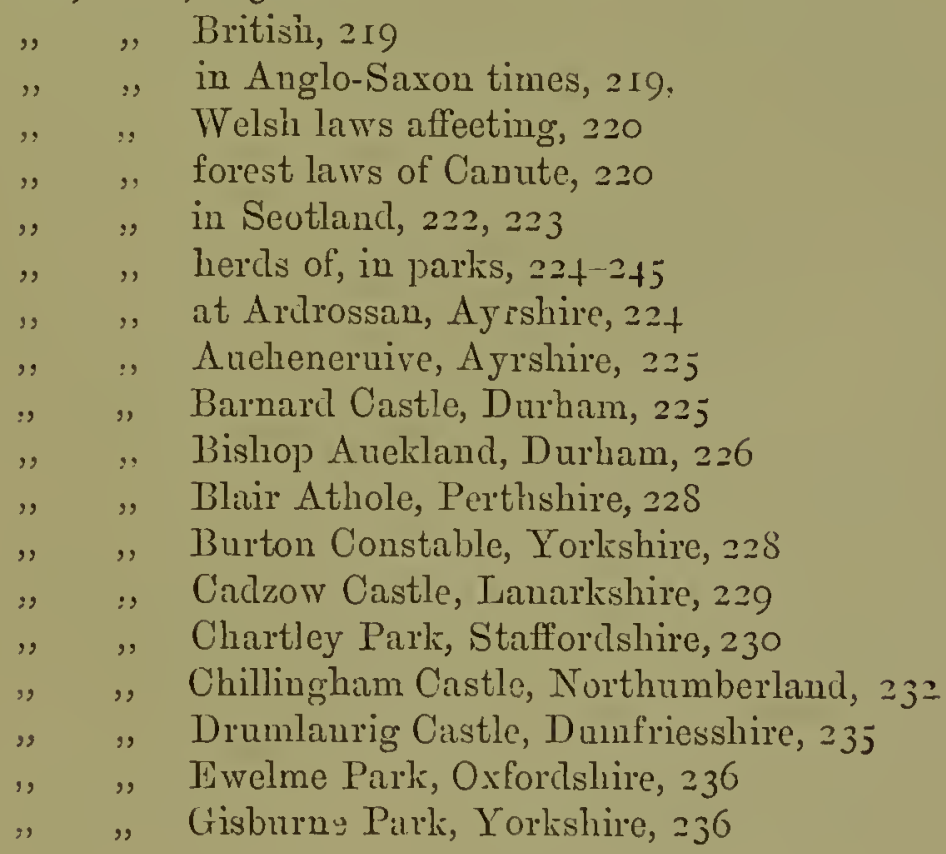


Cattle, Wild, at Hoghton 'l'ower, Lancashire, 239

" " Ioldenby Tark, Nortlamptonshire, 239

" " Kilmory llousc, Argyleshire, 239

" = Leigh Court, Somersetshire, 239

" " lıymc Park, Clicshire, 240

" " Middlcton Park, Jancashire, 242

" , Naworth Castlc, Cumbcriand, 244

", ", Somerford Park, Cheshire, 245

", " Whalley Abbey, Lancashirc, 246

", , Wollaton Park, Notinghamshirc, 246

Charnwoed Forest, 6

Chief Master of the Bears, 27

Chisholm's, the Laird of, adventure with Wolf, 173

Coins, ancient British, 77, 219

Corbet, Pcter, Wolf-huntcr to Edward I., I 43

Cosmo, Grand Duke, travcls in England, I 669, 197

Craven Forcst, 8

Cumberland, Moors and Forests, 4,8

Cunobelin, coin of, 219

Derbysime Moors, 4

Drayton's "Polyolbion," 36, 142

Eldar, Joirs, story of, 165

Erdestwicl's "Survey of Staffordshire," 1593, 86, 97

Ettrick Forest, I6I

Evans's "British Coins," 77

Fitzstepuen's Description of London, I I 74, 5, 84

Flower, Prof. W. H., on cranium of Dog, I 17

Forest of Berc, I19, 136, I37

" of Bowland and Blackburnshire, 7, I 19

" of Irwcll, I I 9

" mear London in I I 74, 5, $\mathrm{S}_{4}$

", of Marr, 76, 95

" of the Pealk, 7, 145

", of Riddlesulale, I 19

" of Savermakc, IoI, I I9, I53

", of Wolmer, 95

Forests, formcr extent of ancient, +9

Giraldus Cambrensis, Itinerary of, 35, 93, i 86

Gordon, story of a Gordon and a Boar, 24, 91

Great Grimsloy, Seal of the Corporation of, $S_{7}$

Hare, or Haia, ro

Hentzner's Itinerary, 29 
Highland Deer Forests, 4

Horns of Reindeer, 7 I, 75

" of Wild Cattle, 216, 21 7, 231, 233

Horn, Hunting-, 10, 149, 205

"Nigell's, 8 r

Household Book of, Earl Ferrers, I02

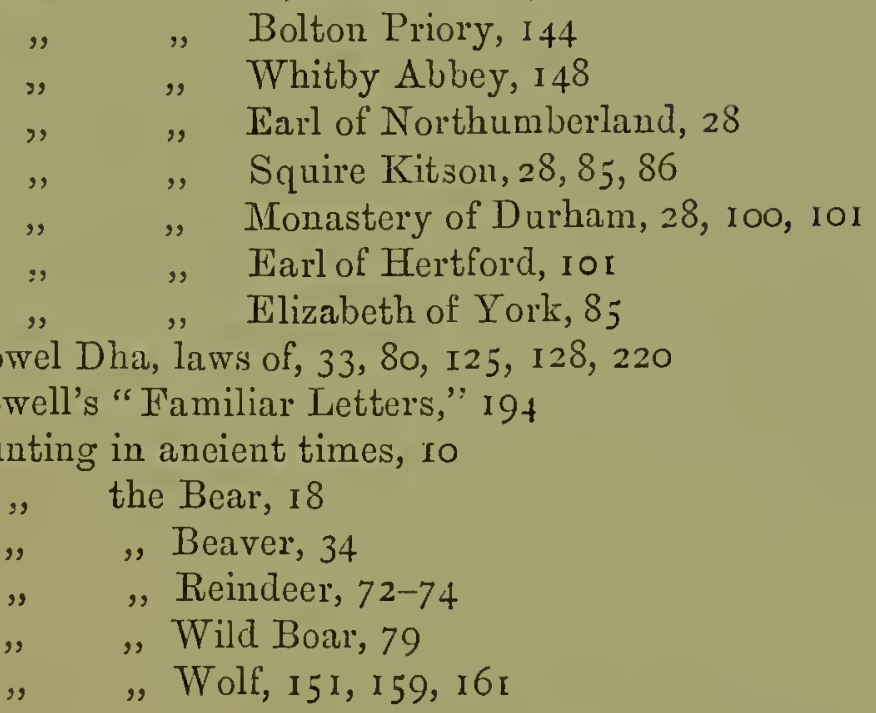

INGLEWOOD Forest, 82

Isle of Bute, Beavers in, 46-59

Ireland, earliest account of wild animals in, 93

, Bear in, 1 3-16, 23

" Reindeer in, 65-66

, Wild Boar in, 92-94

"Wolf in, 185

Jonn, Charter of Liberties of, I 38

Laxcasuire Moors, 4

Lauder, Sir'T. D., aeeount of MLoray F'loods, i 80

Leith Adams, on Trish Fossil Mammals, 14, 65, 67

Liulphus, a eelebrated Wolf-hunter, I33, I54

Llwyd on Welsh MSS., I 7

Lyon, Lady Margaret, and the Wolves, 162

Macclesfield Forest, 7

Macphersor of Braekaely, I7 I

NaeQueen of Pall-a-chrocain, 173

Marr, Forest of, 76, 95

Matthew Paris, I 33

Maxwell Forest, 6

Nemprys, killed by a Wo!f, I 21 


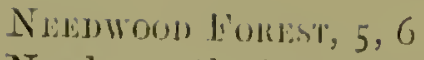

Newbury, the P'eat-pit near, S9

New Forest, 119

Newton, Prof. $\Lambda$., on \%oology of Ancient Jinrope, 151

Nigell and the Wild Bonr, 8 I

Nigell's horn, $\delta_{1}$

Northumberlind Moors, +

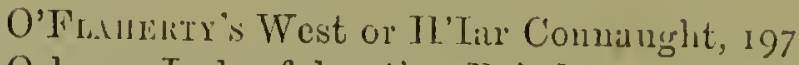

Orkney, Jinls of, liunting Reindecr, 72-74

"Orkneyingr Saga," 72-74

Owen, P'rof., on Tossil Mammals, $12,65,117,215,218$

Paris Garden, 26

"Paw-calf," the, 23, $2+$

Peak, Forest of the, $7,1+5$

Peat-pit near Newbury, 89

Pennarth, 17

"Pcnitentiale" of Abp. Egluert, 19, 124

Pennyles Pilgrimage, I68

Peter Corbet, Wolf-hunter to Edward I., 143

Polson of Wester Helmsdale, 176

"Polychronicon" of Ranulphus Higdcu, 186

"Polyollion" of Nichael Drayton, 36, I 30

QUeEx AxTe, advertisements of Bar-luaiting: 30

., Elizabeth bear-baiting, 27

, Marry Wolf-hunting; 166

Rur, "Synopsis Methodica Animalium," I7

Reindecr, 6I

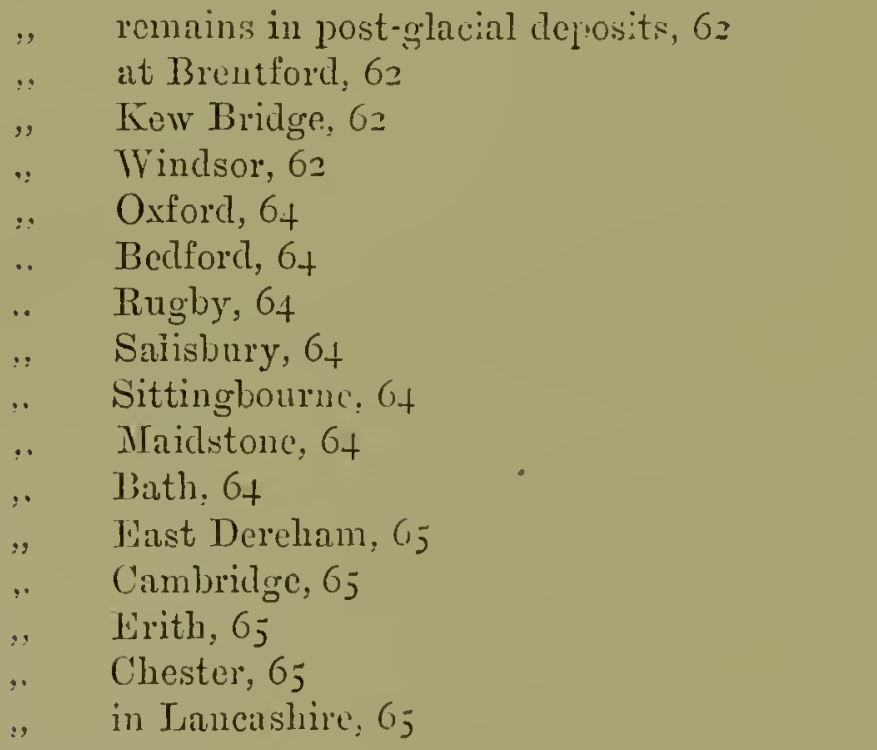


Reindeer in Ireland. 65

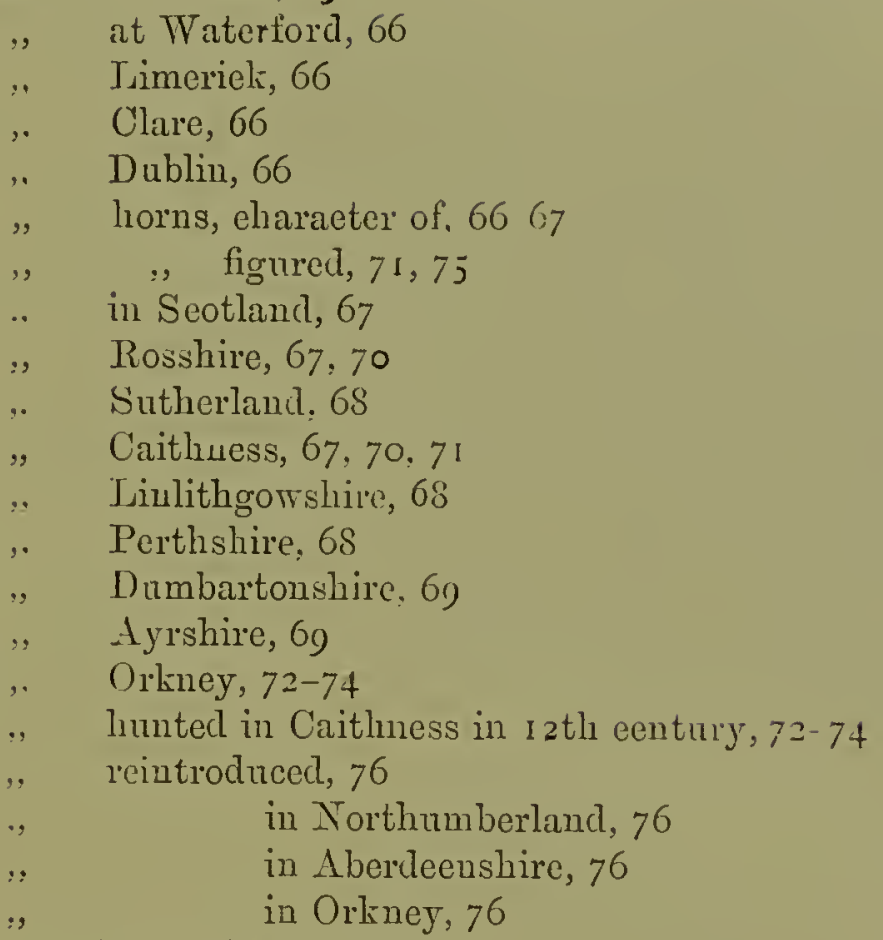

Rewards for slaying Wolves, I 37, 145, 159, 162, 164, I69, 196

Riehmond Forest, II9

Roman monuments in Eugland, 78

Rosendale Forest, 8 , I 54

S.lutix, F. H., his tame Will Boar, i Io

Savernake Forest, Ior, I I9, 153

Seoteh Forests, I 64

Sherwood Forest, 7, 119

Sibbald's "Seotia Illustrata," 40, 169

Skins of Tild Animals, value of, A.D. $940,3+$

Skins used for trimming, 3+, I 57

Smith, "Aneient and Present State of Co. Kerry," I 99

Smith, Dr. J. A., on remains of Bear, I3

$$
\begin{aligned}
& \text {, on remains of Reindeer, 69, } 7 \mathrm{I} \\
& \text {, on aneient Cattle of Seotland, } 215
\end{aligned}
$$

Staffordshire Moors and Forests, 5

Sussex, last Tolf in, I 54

"Swin," names of places eompounded with, 89

Tartor's "Pennyles Pilgrimage," I 58 , ios

Tennent, Sir J. E., on Wolves in Ireland, 202

'Torfarts, aeeount of the Orlineys, 72

Traet, earliest relating to fauna of Ireland, 93

Turbervile on Bonr-hunting, I02-'IOS

, on Wolf-lunting, I90 
'Tusks, cnormous, of Wild Joar, 90, 9I " of large size from Ircland, $9 f$

WatKen's "Mammalia Scotiea," I3 I

Wangford, Beavers at, 59

Welsh historians, notice of Beavers by, 38

" laws of IIowel Dha, 33, 80, 125, I28, 220

"I'Tiads, I6

West or H'Tar Connuught, I97

Westmoreland Moors, 4

White, Gilbert, on Wild Boars in Wolmer Forest, 95

Wild Boar, 77

" its carly mention in history, 77

" figured on British coins, 77

" in Celtic works of art, 77

" on Roman monuments, 78

" at Ribehester, 78

" in Weardiale, 78

" at Birdoswald, 78

" at Little Langford, 79

" in Saxon times, 79

,. period for hunting, so

,, in Forest of Bernwood, So- $8 I$

" in Inglewood Forest, 82

$" \quad$ in Eskdalc, 82, 83

", anecdote of $a, 83$

" near London, 84

" in Oxfordshire, 84

" mode of spearing, 85, II 4

", in Suffolk, 85

" in Staffordshire, 86

, in Northumberland, 86

", in Westmoreland, 86

" in Berkshire, 87, 89

" in Hampshire, 87

$" \quad$ in Lancashire, 87

, in Lincolnshire, 87

$" \quad$ names and places, 89

"St. Andrews, 89, 90

" huge tusks of, 90, 91

" Gaelic names of, 92

" in Perthshire, 92

$" \quad$ in Berwickshirc, 92

$" \quad$ in Freland, 92, 93

" Irish names for, $9+$

" attempted reintroduction of, 94

$" \quad$ in the New Forest,94 
Wild Boar, in Essex, 95, 96

". in Wolmer Forest, 25

" in the Forest of Marr, 95

" in Dorsetshire, 95,96

." in Staffordshire, 97

" in Derbyshire, 97, 98

" date of extinction of, Ioo

" in Durham, Ioo

, in Savernalie Forest, IO I

" in Lancashire, IOI

" at Windsor, , 02

, in Westmoreland, Iо2

", mode of hunting, I02-108

" names firr, at different ages, ios

" a tame one, I Io

Wild Cattle, sce Cattle, Wild

Wolf, I I 5

" formerly eommon in Britain, I 6

", geologieal evidenee, I I 7

", districts formerly infested, I I 8, I I9

" skull of, II7, I2O, I2 I

" hunted by the Britons, I 2 I

" , by the Saxons, I 22

" mentioned in the "Penitentiale" of Abp. Egbert, I 24

" retreat at Flixton, I25

", tribute imposel by Edgar, I25-I 32

" Edgar's house, near Glastonbury, I 32

", Forest larss coneerning, I 32

, on English battle-fields, I 33, I 34

in Northumberland, I34, I49

in Riehmondshire, I35, I47, I 52

in the New Forest, I36

in the Forest of Bere, I36-137

in the Forest of Bowland, I I9, I 55

in Caernarvonshire, $\mathrm{I} 37$

in Devonshire, $\mathrm{I}_{3} \mathrm{~S}$

in Northamptonshire, I39, I4I, I42, I44

in Surrey, I 39

story of Bedd-gelert, I 40

in Leicestcrshire, $\mathrm{I}_{42}$

in Hampshire, 142

in Gloueestershire, I43

in Woreestershire, I 43

in Herefordshire, 143

in Shropshire, I 43

in Staffordshire, I 43

in Huntingdonshire, 144, I48 
Wolf, in Cambridgeslire, if

, in Buckinghamshire, 144,148

.. in Rutlandshire, 144,148

, in Yorkshire, $1+4,1+5,155,156$

, in Derloyshire, 145,146

, in Wiltshire, I 46 , I 53

: in Nottingliamshire, I 47 , I 49

, in Oxfordshire, 148

. in Essex, $143, \mathrm{I} 48$

, in Lancashire, I 5 t, 155

, mames and places, I 54

, in Seotland, I 58

, in the Cilledonian Forest, ito

, in the Ettrick Forest, I6r

$\therefore$ statutes for lestruction of, I6I

, in Mount Caplaeh, 163

, in Scotch forests, $164-168$

, Gaelic names for, I 7 I

", rewards for slaying, $137,145.159,162,164,169,196$

" traditions concerning, I $70-18_{3}$

Trolf-hall, Savernake, IOI, I 53

WVolf's-head, signification of, 124

Wolf-hounds, I 88

" sent as presents, 189.190

, prohibition agaiust exporting, I95.

Wolf-hunt lands, 145-1 49

Wolf-skins, temp. Charles IT., I69

Wolf-stone, the, I 57

TVolves in Ireland, i 85

, in Ulster, 193. 194

,, in M[unster, 192-199

, in Connaught, 197

, nenr Dublin, 193

"s in Cork, 198

$:$ in Kerry, I99

.. proposed Act for ciestruction of, in Ireland, 193, I97

, names and places, I $S_{3}, 184$

" date of extinction, 204

Verstegars, "Restitution of deeayed intelligence," I23, I2 4

YoRksIIRE MLoRs, 4 



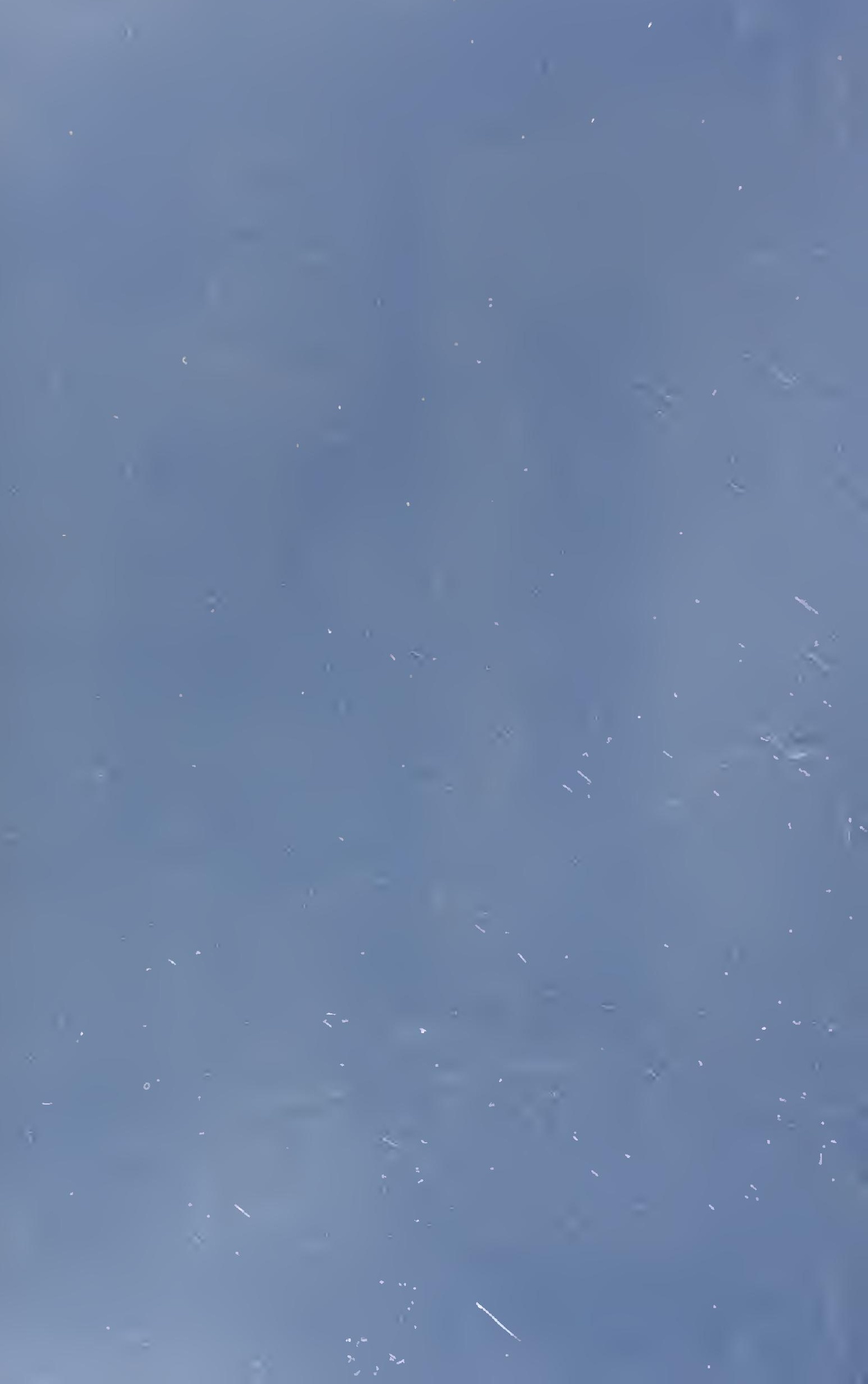


